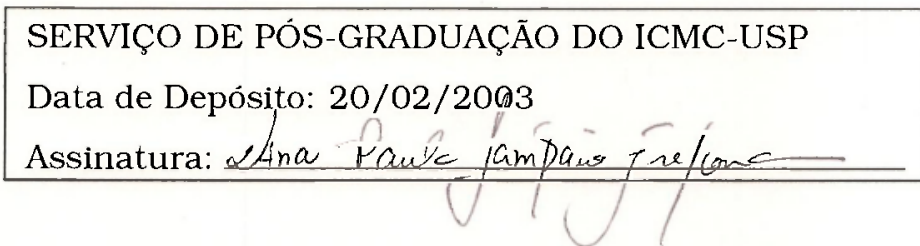

\title{
Implantação do reúso de componentes no processo de desenvolvimento de software
}

\author{
Talita Andréa Avante Rozante
}

Orientadora: $\operatorname{Prof}^{a} \mathrm{Dr}^{a}$ Rosely Sanches

Dissertação apresentada ao Instituto de Ciências Matemáticas e de Computaçāo - ICMC/USP, como parte dos requisitos para obtenção do título de Mestre em Ciências de Computação e Matemática Computacional.

USP - Sāo Carlos

Fevereiro de 2003 
A Comissão Julgadora:

Profa. Dra. Rosely Sanches

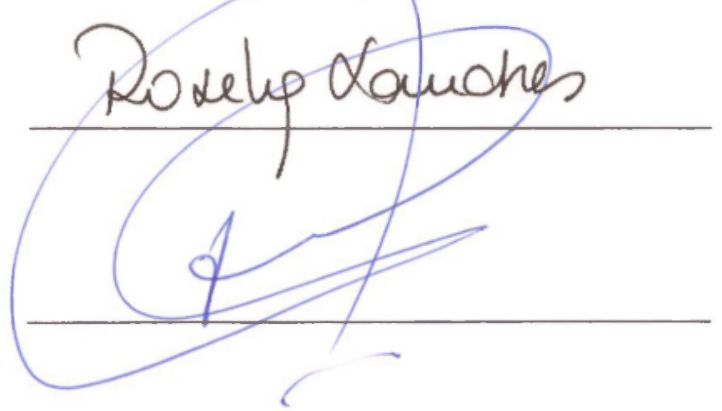

Prof. Dr. Mauro de Mesquita Spinola

Saunotimspirda 
Este documento foi preparado com o formatador de texlos ETEX. O sistema de citaçôes de referências bibliográficas utilizado foi $\mathrm{BlBT}_{\mathrm{E}} \mathrm{X}$ padrão chicago. 
Dedicatória

Aos meus pais e irmāos. 


\section{Agradecimentos}

Aos meus pais. irmãos e familiares, que sempre me deram o apoio necessário para crescer tanto pessoalmente como profissionalmente.

$\grave{\Lambda}$ Rosely, que além de auxiliar seus alunos em suas pesquisas, ofercce também apoio. dedicação, compreensão e carinho, sendo mais do que uma simples orientadora por dois anos, mas uma grande amiga para toda a vida.

Ao Marcos, por todo apoio, carinho e alençào, contribuindo tanto pessoal como prolissionalmente para o alcance destc e de muitos outros objetivos.

Às meninas da república Iceberg. Ana Carolina, Tatiana e Thaís, que sempre propiciaram um ambiente agradávcl c descontraído, tanto nas horas de estudo como nas horas de lazer e descanso.

Às professoras Maria Carolina Monard c Solange de Oliveira Rezcnde e aos alunos Ronaldo Prati, Marcos Geromini e Gustavo Batista, que tanto contribuiram para a cxccuçāo do estudo de caso e. conseqüentemente, para a concretização da proposta deste mestrado.

À Capes, pelo apoio financeiro.

Aos funcionários c professores do Instituto de Ciĉncias Matcmáticas e de Computação. cujo trabalho permitiu a existência da infra-estrutura necessária para as pesquisas realizadas.

E, por fim, a Deus, que iluminou meu caminho e guiou meus passos para o alcance de mais este objctivo. 


\section{Resumo}

Frente à grandc demanda por software e à fortc competitividade existente no mercado atual. o alcance de alguns objetivos, tais como aumento de qualidade e de produtividade redução dos prazos de entrega e dos custos globais do desenvolvimento de software, tem sido apresentado como bastante importante para o sucesso de umá organizaçào de desenvolvimento de sistemas. Neste ccnário, o reúso sistemático de componentes de softuare tem exercido o papel de grande colaborador para o alcance desses objetivos.

Para a concrctização de sua prática efetiva. porém. o reúso vêm cnfrentando barreiras de diversas origens, como questões técnicas e organizacionais. Assim. é importante que a introdução do reúso aborde tais questōes de maneira integrada e gradativa, respeitando o tempo natural da organização para a absorção de mudanças e cuidando para que seu impacto seja reduzido.

Desta mancira, o principal objetivo deste projeto foi o desenvolvimento de uma estratégia que sistematizasse o processo de introdução do reúso em uma organização, considerando mudanças organizacionais, técnicas e processuais, assim como sua seqüência de execução, suas conscqüēncias e dificuldades. Para criar e validar esta estratégia. foi desenvolvido um estudo de caso no Laboratório de Inteligćncia Computacional do Instituto de Cièncias Matemáticas e de Compulação da Universidade de Sāo Paulo. Neste estudo de caso, for tambėm selecionado um conjunto minimo de atividades e requisitos importantes para via bilização do reúso e desenvolvida a especificação de um ambiente. denominado RaCooMN (Reusable Components Management ENvironment). que automaliza muitas das atividades propostas na estratégia referentes ao armazenamento e gerenciamento dos componentes. 


\section{Abstract}

It is very important for the success of a software development organization to achieve objetives such as the productivity and the quality raise, delivery time and software development global costs reduced. In this context, the systematic reuse of software components has assumed the role of an important collaborator in order to reach thesc objectives.

In order to become a concrete practice, however, the reuse faces several barriers re garding technical and organizational issues. Thus, it is important that, when introducing reuse in an organization, we consider these issues in an integrated and gradual manner, observing the time for the organization to absorb changes and also trying to reduce its impact.

The main objective of this project was to develop a strategy to systematize the introduction of the reuse in an organization, considering organizational, technical and processual changes, as well as their execution sequence, consequences and difficulties. In order to create and validate this strategy, we developed a case study at a computing laboratory in the ICMC. $\Lambda$ dditionally, it was sclected a minimum set of activities and requirements to make reuse possible. Moreover, it was developed an environment specification, named RaCooMn (Reusable Components Management ENvironment), aimed at automatize some strategy activities regarding component storage and management. 


\section{Sumário}

\section{Lista de Figuras}

1 Introdução

1.1 Motivaçăo . . . . . . . . . . . . . . . . . 2

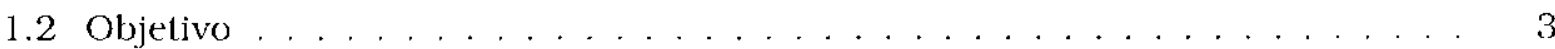

1.3 Organização do Trabalho . . . . . . . . . . . . . . 3

2 O Reúso de Software 5

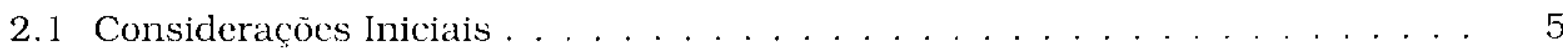

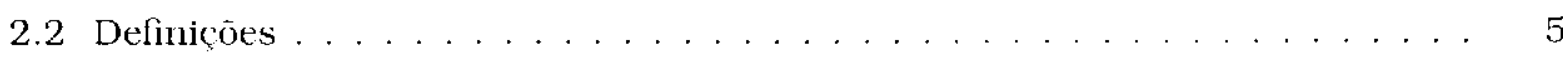

2.3 Reüso Versus Qualidade de Software . . . . . . . . . . . . . . . . . . . . 8

2.4 O Programa de Reúso $\mathrm{cm}$ uma Organização . . . . . . . . . . . . . 11

2.4 .1 Planejamento do Reúso . . . . . . . . . . . . . . . . . 11

2.4 .2 Guestōes Organizacionais. Gerenciais e de Pessoal . . . . . . . . . 12

2.4.3 Guestōes de Dominio, Processo c Técnicas . . . . . . . . . . . . . . . 14

2.5 Atividades Espccificas do Processo de Desenvolvimento de Software com Reúso 15

2.6 O Repositório de Componentes . . . . . . . . . . . . . . . . 17

2.6.1 Técnicas de Classificação de Componentes . . . . . . . . . . . 18

2.7 Caractcrizaçāo de Componentes . . . . . . . . . . . . . . 21

2.8 Padrōes e Critérios de Qualidade para Componentes . . . . . . . . . . . 23

2.9 Consideracōes Finais . . . . . . . . . . . . . . . . . . . . . . 25

3 Melhoria de Processo de Desenvolvimento de Software 27

3.1 Consideraçóes Iniciais . . . . . . . . . . . . . . . . . . . . . . . . . 27 
3.2 o Modelo IDEAL . . . . . . . . . . . . . . . . . . . . 27

3.3 Fases do Modelo IDEAL . . . . . . . . . . . . . . . . . . . . 28

3.3 .1 Fase de Inicialização . . . . . . . . . . . . . . . . . . . . 29

3.3 .2 Fase de Diagnóstico . . . . . . . . . . . . . . . . . . 30

3.3 .3 Fase de Estabelecimento . . . . . . . . . . . . . . . 31

3.3 .4 Fase de Açāo . . . . . . . . . . . . . . . . . . . . . . . . 31

3.3 .5 Fase de Liçoes . . . . . . . . . . . . . . . . . . . . . 32

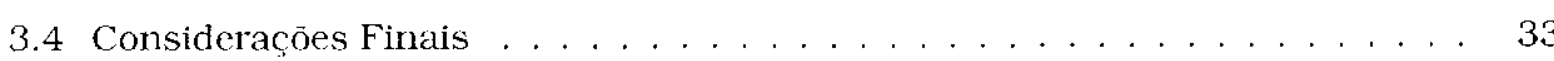

4 A Norma NBR ISO/IEC 12207 - Processos de Ciclo de Vida de Software 35

4.1 Consideraçōes Iniciais . . . . . . . . . . . . . . . . . . . . . 35

4.2 A Norma NBR ISO /IEC $12207 \ldots \ldots \ldots \ldots$

4.3 Considerações Finais . . . . . . . . . . . . . . . . . . . . 38

5 Documentação de Software $\quad 41$

5.1 Consideraçōes Iniciais . . . . . . . . . . . . . . . . . . . 41

5.2 Documentação de Software . . . . . . . . . . . . . . . . 41

5.3 Processo de Documentação . . . . . . . . . . . . . . . . . . . . . 43

5.3.1 Implementação do Processo . . . . . . . . . . . . . 43

5.3 .2 Projeto e Desenvolvimento ................... . 45

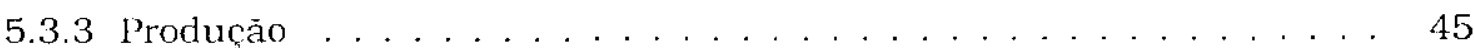

5.3 .4 Manutençāo . . . . . . . . . . . . . . . . 45

5.4 Caracteristicas de uma Documentaçāo Efctiva . . . . . . . . . . . . . . 46

5.5 Un Padrào Para Documentaçāo . . . . . . . . . . . . . . . . . . . . . . . 47

5.6 Consideraçòes Finais . . . . . . . . . . . . . . . . . . . . 47

6 Revisão Técnica Formal $\quad 49$

6.1 Considerações Iniciais . . . . . . . . . . . . . . . . . . . . . . . 49

6.2 Revisōes Técnicas Formais . . . . . . . . . . . . . . . . . . . . . . . . . 49

$6.3 \wedge$ Reunião de Revisão . . . . . . . . . . . . . . . . . . . . . . . . . 50

6.4 Diretrizes para Realização da Reuniāo . . . . . . . . . . . . . . . . . 51

6.5 Consideraçōes Finais . . . . . . . . . . . . . . . . . . . 53 
7 Gerenciamento da Configuração de Software 55

7.1 Consideraçòes Iniciais . . . . . . . . . . . . . . . . . 55

7.2 Gerenciamento de Configuraçäo de Software $\ldots \ldots \ldots \ldots 5$

7.3 Alividades do Gerenciamento de Configuraçāo . . . . . . . . . . . 57

7.3.1 Implementação do Processo . . . . . . . . . . . . . . . . 57

7.3 .2 Identificaçāo da Configuração . . . . . . . . . . . 58

7.3 .3 Controle da Configuração . . . . . . . . . . . . . . . . . 59

7.3 .4 Relato da Situação . . . . . . . . . . . . . . . . . . . . . . . 62

7.3 .5 Avaliação da Configuraçāo . . . . . . . . . . . . . . 62

7.3 .6 Controle de Interface . . . . . . . . . . . . . . . . 63

7.3.7 Controle de Sub-Contratados c Fornccedores . . . . . . . . . . 63

7.3 .8 Gerência da Liberação e Entrcga . . . . . . . . . . . . . . . . . . . 64

7.4 Consideraçòes Finais $\ldots \ldots \ldots \ldots \ldots . \ldots \ldots$

8 Diretrizes para o Processo de Implantaçāo do Reúso 65

8.1 Consideraçóes Iniciais . . . . . . . . . . . . . . . . . . . 65

8.2 Os Artefatos e os lípos de Reúso . . . . . . . . . . . . . 66

8.3 Estratégia para Implantaçāo do Reủso . . . . . . . . . . . . . . 67

8.3 .1 Inicializaçāo . . . . . . . . . . . . . . . . . . . . 68

8.3 .2 Diagnóstico c Estabclecimento . . . . . . . . . . . . . . . 69

8.3 .3 Ação . . . . . . . . . . . . . . . . . . 70

8.3 .4 Liçōes . . . . . . . . . . . . . . . . . . . . . . . . 72

8.4 Operacionalização da Estratégia . . . . . . . . . . . . . . . . . 72

8.5 Atividades Sugeridas para o Início do Processo de Introduçào do Reúso . . . 74

8.5.1 Documentação . . . . . . . . . . . . . . . . . 74

8.5 .2 verificação . . . . . . . . . . . . . . . . 87

8.5 .3 Gerência de Configuraçāo . . . . . . . . . . . . . . . . 95

8.6 Consideraçoes Finais . . . . . . . . . . . . . . . . . . . . . . . . 109

9 RaCooMN - Reusable Components Management ENvironment 111

9.1 Consideraçócs Iniciais . . . . . . . . . . . . . . . 111

9.2 O Processo de Especificaçāo do Ambiente RaCoomn . . . . . . . . . . 111

9.3 RaCoomn - Fase de Engenharia de Requisitos . . . . . . . . . . . . 113 
9.3.1 Diagramas e Especificaçōes de Casos de Uso . . . . . . . . . . . . . 113

9.3 .2 Diagramas das Classes de Domínio . . . . . . . . . . . . . . . 149

9.4 Consideracones Finais . . . . . . . . . . . . . . . . . . . 158

$\begin{array}{lr}10 \text { Conclusões e Trabalhos Futuros } & 159\end{array}$

10.1 Liçoes Aprendidas . . . . . . . . . . . . . . . . . . . . . . . 161

10.2 Contribuiçōes . . . . . . . . . . . . . . . . . . . . . 162

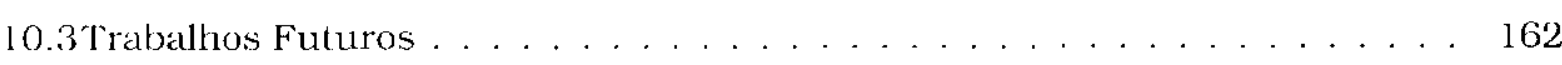

Referências Bibliográficas e Bibliografia $\quad 165$

$\begin{array}{lr}\text { A Estudo de Caso } & 171\end{array}$

A.l O Ambiente do Estudo de Caso . . . . . . . . . . . . . . . 171

A.1.1 Historico ............................ 172

A.1.2 O Reúso no Discover . . . . . . . . . . . . . . . . 173

A.2 As Reuniōes . . . . . . . . . . . . . . . . . . . . . . . 174

A.2.1 Reuniào I: Validação do Cronograma . . . . . . . . . . . . . . . 174

A.2.2 Reunião II: Definição dos Requisitos para o Código Fonte . . . . . . . 175

A.2.3 Reunião III: Definição de Regras para Documentaçāo de Externa . . . . 178

ヘ.2.4 Reuniōes IV c V: Definição do Processo de Execuçāo de Revisōes Técnicas Formais . . . . . . . . . . . . . . . . 180

A.2.5 Reuniāo VI: Definiçào do Plano de Gerenciamento de Configuraçāo . . 182 


\section{Lista de Figuras}

2.1 Fatores da gualidade de Software . . . . . . . . . . . . . . 8

3.1 O Modelo IDEAL . . . . . . . . . . . . . . . . . . . . . . 29

4.1 Processo do Ciclo de Vida do Software . . . . . . . . . . . . . . 36

5.1 O Processo e Alguns Documentos Envolvidos no Ciclo de Vida do Software de Acordo com a NBR ISO/IEC $12207 \ldots \ldots \ldots$. . . . . . . . . . . 44

6.1 Reuniāo de Revisāo de Software . . . . . . . . . . . . . . . . . . . . 52

7.1 Gerenciamento de Configuraçāo de Software . . . . . . . . . . . . . . 57

7.2 Check-In/Check-Out . . . . . . . . . . . . . . 58

7.3 Processo de Controle . . . . . . . . . . . . . . . . . 60 60

7.4 Árvore de Versōes de um Documento sob Controle de Versäo . . . . . . . . . . 61

8.1 Estratégia de Melhoria Continua Utilizada no Processo de Inplantaçào do Reú-

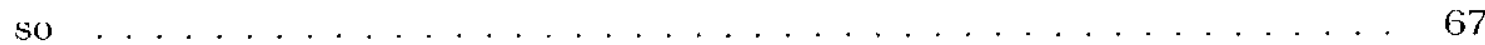

8.2 NBR ISO/IEC 12207 - Processos Selecionados . . . . . . . . . . 70

8.3 Etapas da Fase de Ação . . . . . . . . . . . . . . . . . . . 71

8.4 Relação Entre as Funcionalidades do Repositório de Componentes e a Documentação, a Revisāo Técnica Formal c o Gerenciamento de Configuração . . . 75

8.5 Disponibilização dos Componentes para o Processo de Verificação . . . . . . . 89

8.6 Componente $\Lambda$ provado Sem Modificaçōes . . . . . . . . . . . . . . . . . . 90 90

8.7 Componente Aprovado Provisoriamente . . . . . . . . . . . . . . 91

8.8 Componente Reprovado . . . . . . . . . . . . . . . . . . . . 91 91

8.9 Exemplo de Estrutura do Repositorio . . . . . . . . . . . . . . 102

8.10 Processo de Altcração de un Item de Configuração . . . . . . . . . . . 105 
9.1 Diagrama de Caso de Uso - Cadastro de Usuário . . . . . . . . . . . . . 116

9.2 Diagrama de Caso de Uso - Cadastro de Área de Trabalho . . . . . . . . . 117

9.3 Diagrama de Caso de Uso - Conexāo ao Ambiente . . . . . . . . . . . . 118

9.4 Diagrama de Caso de Uso - Desconexāo do Ambiente . . . . . . . . . . . . . 119

9.5 Diagrama de Caso de Uso - Busca de Componentes . . . . . . . . . . . . 120

9.6 Diagrama de Caso de Uso - Visualização e Obtenção da Documentaçāo de um

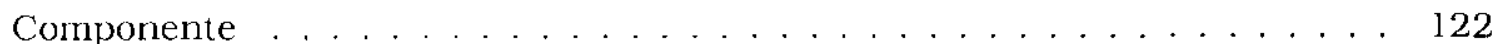

9.7 Diagrama de Caso de Uso - Registro de Componentes em Desenvolvimento . 124

9.8 Diagrama de Caso de Uso - Registro do Cancelamento de um Componente em

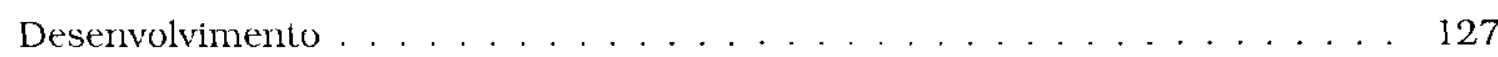

9.9 Diagrama de Caso de Uso - Registro de Novos Componentes . . . . . . . . 127

9. 10 Diagrama de Caso de Uso - Seleção dos Revisores e do Lider da Revisāo de um

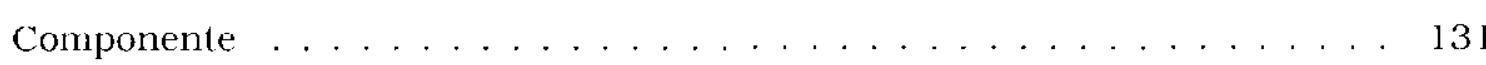

9. 1 l Diagrama de Caso de Uso - Agendamento da Rcunião de Revisão de um Com-

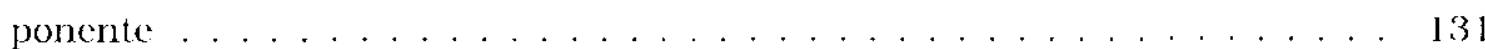

9.12Diagrama de Caso de Uso - Visualização dos Componentes Selecionados para Serem Revisados por um Determinado Revisor . . . . . . . . . . . . . . . . . 133

9.13Diagrama de Caso de Uso - Cadastro do Resultado de uma Revisāo de um

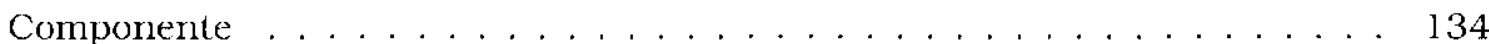

9. 14 Diagrama de Caso de Uso - Visualização do Resultado de uma Revisāo de um

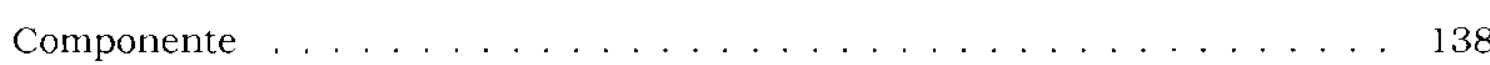

9.15 Diagrama de Caso de Uso - Solicitação de Pedido de Alteracão . . . . . . . . 141

9.16 Diagrama de Caso de Uso - Visualização dos Pedidos de Alteração a Serem

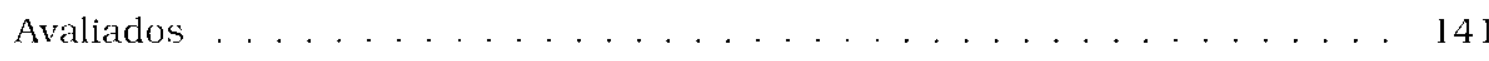

9.17 Diagrama de Caso de Uso - Cadastro do Resultado da Avaliação de um Pedido de Altcração de um Componente . . . . . . . . . . . . . . . . 144

9.18Diagrama de Caso de Uso - Visualizaçāo do Resultado da Avaliaçāo de um P'edido de Alteraçào . . . . . . . . . . . . . . . . . . . . . 145

9.19Diagrama de Caso de Uso - Documentação de Alteraçōes cm um Componente 148 9.20 Diagrama de Caso de Uso - Visualizaçào de Relatórios . . . . . . . . . . . . . 148

9.21 Diagrama de Classes - Visão Usuário . . . . . . . . . . . . . . . . . 151

9.22 Diagrama de Classes - Visāo Componentes Em Desenvolvimento . . . . . . 152 
9.23 Diagrama de Classes - Visāo Componentes (Documentação) . . . . . . . . . 154

9.24 Diagrama de Classes - Visão Componentes - Primeira Parte . . . . . . . . . . 155

9.25 Diagrama de Classes - Visāo Componentes - Segunda Parte . . . . . . . . . 156

9.26 Diagrama de Classes - Visào Revisāo . . . . . . . . . . . . . . . . . . . . . . 157

9.27 Diagrama de Classes - Visão Pedido de Alteračào . . . . . . . . . . . . . . . 158 


\section{Lista de Tabelas}

6.1 Comparação de Custo de Desenvolvimento . . . . . . . . . . . . . 51

8.1 Informaçōes Referentes às Classes . . . . . . . . . . . . . . . . 84

8.2 Informaçōes Referentes a Cada Um dos Métodos de Umá Classe . . . . . . . . 85

8.3 Atributos Sugeridos para Uso na Busca por Componentes . . . . . . . . . 86

8.4 Requisitos Essenciais Aos Componentes (Aprovaçào Provisoria) Referentes à Documentação Externa ......................... 93

8.5 Requisitos Essenciais Aos Componentes (Aprovação Provisória) Referentes à

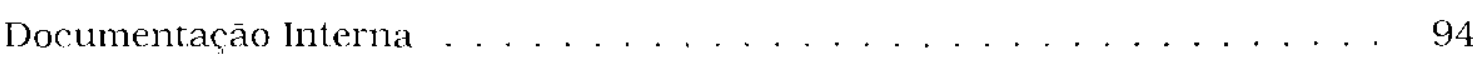

9. 1 Correspondência entre os Diagramas das Fases do ProDes/UML e os Diagra-

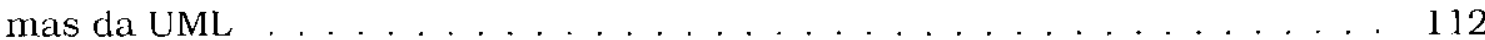

9.2 Estrutura da Especificação dos Casos de Uso . . . . . . . . . . . . . 115

9.3 Especificação de Caso de Uso - Cadastro de Usuário . . . . . . . . . . . . . . 116

9.4 Especificaça de Caso de Uso - Cadastro de Árca de Trabalho . . . . . . . . 118

9.5 Especificação de Caso de Uso - Conexão ao Ambiente . . . . . . . . . . . 119

9.6 Especificaçào de Caso de Uso - Desconexão do Ambiente . . . . . . . . . . . 120

9.7 Especificação de Caso de Uso - Busca de Componentes . . . . . . . . . . . 121

9.8 Especificação de Caso de Uso - Visualização da Documentaçāo de um Com

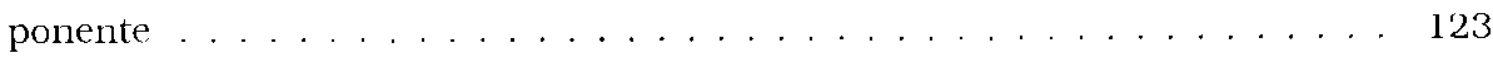

9.9 Especificaçāo de Caso de Uso - Obtenção da Documentaçāo de um Componente 124

9. 10Especificação de Caso de Uso - Registro de Componentes em Descnvolvimento 125

9.11 Especificação de Caso de Uso - Registro do Cancelamento de um Componente em Desenvolvimento . . . . . . . . . . . . . . . . . . 126

9.12 Especificação de Caso de Uso - Registro de Novos Componentes . . . . . . . 129 
9.13Especificaçāo de Caso de Uso - Seleção dos Revisorcs c do Lider da Revisão de um Componente . . . . . . . . . . . . . . . . . . . 130

9.14Especificação de Caso de Uso - Agendamento da Reunião de Revisāo de um

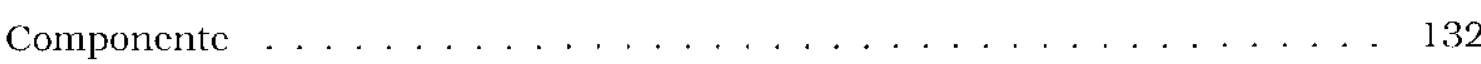

9.15Especificação de Caso de Uso - Visualização dos Componentes Selecionados para Serem Revisados por um Determinado Revisor . . . . . . . . . . . . . . 133

9.16Especificação de Caso de Uso - Cadastro do Resultado de uma Revisâo de um

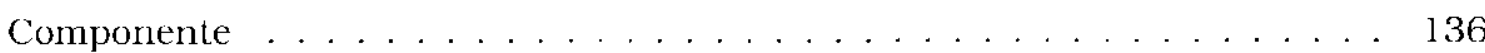

9.17 Espccificaçāo de Caso de Uso - Inserção de um Componente Aprovado no CVS 137

9.18Especilicação de Caso de Uso - Inserçāo de um Componente Aprovado Provi-

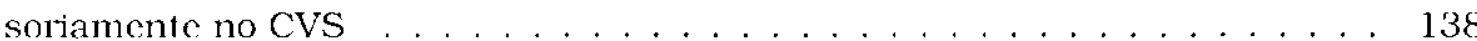

9.19Especificação de Caso de Uso - Visualização do Resultado de uma Revisão de um Componente . . . . . . . . . . . . . . . . . . . 139

9.20 Especificação de Caso de Uso - Solicitação de Pedido de Alteraçāo . . . . . . . 140

9.21 Especificação de Caso de Uso - Visualizaçāo dos Pedidos de Alteração a Serem Avaliados . . . . . . . . . . . . . . . . . . . . . 142

9.22 Especificaçāo de Caso de Uso - Cadastro do Resultado da Avaliaçāo de um Pedido de Alteraçāo de um Componente . . . . . . . . . . . . . . . . 143

9.23 Especificação de Caso de Uso - Disponibilizar um Componente para Alteração 144

9.24 Especificação de Caso de Uso - Visualização do Resultado da Avaliação de um Pedido de Alteração . . . . . . . . . . . . . . . . . . . . . . . . . 146 9.25Especificação de Caso de Uso - Documentação de Alterações em um Compo-

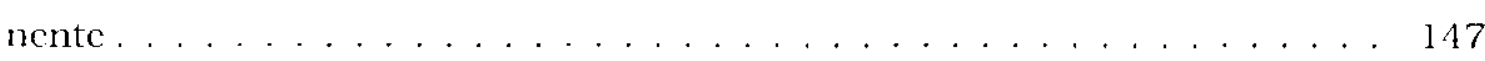

9.26 Especificação de Caso de Uso - Visualização de Relatórios . . . . . . . . . . 149 


\section{Capítulo 1}

\section{Introdução}

Já hả algum tempo as organizações de desenvolvimento de software têm vivenciado um conjunto de problemas cncontrados no desenvolvimento de sistemas. como estimativas de custo e prazo imprecisas, software com qualidade inadcquada, insatisfação do cliente rom o produto final, entre outros. A este conjunto de problemas deu-se o nome de afliçáo crônica. Frente à grande demanda por software e à forte competitividade existente no mercado atual, tais problemas podem inviabilizar a sobrcvivència de uma organização.

É neste contexto que o alcance de alguns objctivos, tais como aumento da qualidade e da produtividade, reduçăo dos prazos de entrega, reduçāo dos custos globais do descnvolvimento de software, entre outros, tem sido apresentado como bastante importante para o sucesso de uma organização de desenvolvimento de sistemas.

O reuiso sistemático de componentes de software tem colaborado de forma significativa para o alcance desses objetivos (Holanda. Souza, \& Mclo 2000). Bascado no desenvolvimento de sistemas a partir de componentes pré-existentes, identificando semelhanças cntrc o novo sistema e esses componentes, tal modelo permite reduçōes significativas de custo e tempo de desenvolvimento. Segundo Neighbors (1992), "Nosso desejo de construir sistemas de software a partir de componentes de softuare reutilizáveis representa uma mudança da produção artesā para a produção em massa. Esta mudança nos é impostá pelos cada vez maiores sistemas de software que precisamos construir".

O reúso, como definido atualmente, pode entào ser visto como uma maneira de atingir algums dos objetivos gerais de uma organização, visto que essa tem que reduzir o tempo de desenvolvimento de seus produtos, diversifica-los, padronizá-los e integrá-los, a fìm de manter-se no mercado. 
Porém, a introduçāo do ré́so no processo de desenvolvimento de software envolve mu danças em diversos itens da organização, como processos, técnicas e até mesmo cultura organizacional, sendo, portanto. uma tarefa dificil de ser executada.

Desta maneira, e importante que o processo de introdução do reùso aborde todas essas mudanças de uma maneira intcgrada e gradativa. Alćm disso, ć preciso que cle seja um processo bem definido, gerenciado, controlado, medido e com constante preocupação de permitir o crescimento na sua capacidade.

Para que este esforço de melhoria resulte em um processo de desenvolvimento de software baseado no reúso de componentes que seja de qualidade, também é necessário que o mesmo possua como objetivo final a implantação das melhores práticas propostas pela comunidade de Engenharia de Software. Dada essa necessidade, o uso de modelos de referência para a capacitaçāo do processo de sofiwuare é de grande ajuda.

Todavia, como citado anteriormente, tais práticas devem ser incorporadas à organização de maneira gradativa. Sendo assim, é preciso que se faça uma análise para levantamento das necessidades mais latentes da organização e, a partir dessa análise, se estabcleça uma ordem para abordagem das diversas präticas.

\subsection{Motivação}

Diante de tantas dificuldades, tantas barreiras a serem transpostas, acrescidas pcla preocupação em modificar o que, de alguma maneira, está funcionando, embora os benefícios do reúso sejam claros, muitas organizaçōes nāo se interessam em implantá-lo ou fracassam $\mathrm{cm}$ suas tentativas.

Frente a tal realidade, pode ser de grande utilidade a criação de uma estratćgia que guie a implantaçào sistemátiča do reúso de componentes no processo de desenvolvimento de software. Para tanto, esta estratégia procura auxiliar as organizaçōes a gerenciar os recursos $e$ as atividades, identificar as questōes criticas c os esforços, tanto educacionais como estruturais e processuais, necessários para que o reúso scja praticado de forma cficiente e efetiva por todo o escopo da organização que deseja implantá-lo.

Uma outra questāo que motivou a escolha do reúso como tema deste mestrado foi a constataçāo de que um laboratório de pesquisa, localizado dentro da universidade e, portanto, em contato com as mais avançadas tecnologias, tinha dificuldade em reaproveitar os produtos de seus pesquisadores. É importante ressaltar, no cntanto. que. por realizarem pesquisas na área de Inteligència Artificial, os pesquisadores desse laboratório não estāo habituados a muitas das práticas pregadas pela Engenharia de Software. 


\subsection{Objetivo}

O principal objetivo deste projeto de mestrado é o desenvolvimento de uma estratégia que sistematize o processo de introdução do reúso em uma organizaçāo, auxiliando-á lla definição das atividades e requisitos necessários para o alcance dos bencicios esperados advindos desse reuiso.

Para criar e verificar a aplicabilidade da cstratégia proposta. além de levantar as atividades c requisitos primordiais para o reúso de componentes, um estudo de caso foi desenvolvido. Esse estudo de caso foi realizado no Laborátorio de Inteligéncia Computacional (LABIC) do Instituto de Ciências Matemáticas e de Computaçao (ICMC), mais especificamente con a introdução do reúso no processo de desenvolvimento de software dos trabalhos de pesquisa relacionados ao processo de Extração de Conhecimento de Bases de Dados através do ambiente Discover (Baranauskas \& Batista 2000). Desta mancira, este trabalhou procurou aliar seus objetivos às necessidades deste laboratório, colaborando não somente com a comunidade de pesquisa da área de Engenharia de Softurare. mas também com o LABIC.

\subsection{Organização do Trabalho}

Esta dissertaçäo apresenta diversos tópicos, relacionados à revisão bibliográdica e aos produtos deste trabalho de mestrado. organizados em 10 capitulos $\mathrm{c}$ um apéndice.

Neste capítulo foi apresentada uma breve contextualização e motivação para trabalho realizado.

No Capitulo 2 são apresentados alguns conccitos e questōes relevantes do descnvolvimento de softuare baseado no reúso de componentes.

O modelo IDEAL. cujo objctivo è guiar as organizaçóes na melhoria continua de seu processo de desenvolvimento de software, possui sua filosolia e fases descritas no Capitulo 3.

No Capítulo 4 é apresentada a norma NI3R ISO/IEC 12207. um modelo de referéncia para capacitação de processo.

O processo de construção de uma boa documentacào e algumas características importantes para a mesma são descritos no Capitulo 5 .

No Capítulo 6 e apresentado o processo de execuçăo de revisōes técnicas formais, ativi dade importante na garantia da qualidade de software.

O processo de gerenciamento de configuraçăo de software é descrito no Capítulo 7. 
No Capítulo 8 é descrita a estratégia para implantaçāo do reúso no processo de desenvolvimento de software, assim como as tarefas e requisitos sugeridos para serem implantados inicialmente pelas organizaçōes.

No Capítulo 9 é apresentada a especificação de um ambiente que visa automatizar algumas das atividades referentes ao armazenamento e gerenciamento dos componentes propostas na estratégia citada.

As conclusōes e propostas de trabalhos futuros säo relacionadas no Capítulo 10.

Por fìm, no Apēndice A, sāo apresentadas algumas consideraçōes sobre os trabalhos desenvolvidos no estudo de caso realizado neste mestrado. 


\section{Capítulo 2}

\section{O Reúso de Software}

\subsection{Considerações Iniciais}

O reúso de componentes tem sido encarado na Engenharia de Softuare como uma opçāo na tentativa de se otimizar o processo de desenvolvimento de sistemas.

Neste contexto, sendo o reuso o objeto de estudo deste trabalho, inicia-se este capítulo com algumas definiçōes referentes ao mesmo. seguidas por algumas consideraçōes sobre o processo de desenvolvimento de software baseado no reúso, sobre o repositório e, finalmente, sobre os componentes.

\subsection{Definições}

$\Lambda$ idéia de reutilizaçăo de soluçōes nāo é algo novo. Sempre que defronta-se com questōes semclhantes tenta-se adaptar a solução de uma a outra, principalmente porque quando uma solução é utilizada exaustivamente ela se torna um padrào, aceito, gencralizado $\mathrm{c}$ já testado. A comunidade da ảrea de Engenharia de Software também tem incorporado a idéia da reutilização de soluçōes para a construção de novos sistemas.

Inicialmente, Mcilroy, segundo apresentado por Schafer, Prieto-Diaz, \& Matsumoto (1994), detiniu o reúso de software como sendo o uso de componentes de sofiware (produtos de pratelcira) como blocos para a construçāo de grandes sistemas, assumindo que esses componentes sāo constituidos de código-fonte.

Posteriormente, Frecman (1987) definiu reúso como o uso de produtos não executáveis para o desenvolvimento de software, indicando que apenas o uso de código-fonte não ì suficiente, já que tal prática ainda exige muito esforço dos desenvolvedores nas atividades de análise e projeto, cujos produtos também podem ser reutilizados. 
Assim, de maneira mais completa. pode-se definir o reúso de software como o processo de criaçào de sistemas a partir de "bens de software" lou componentes de softuare reutilizáveis) (Karlsson 1995). Chamou-se "bens de software" qualquer artefato ou produto de (descnvolvimento de) software tais como códigos. especificaçóes de projeto, conhecimento de domínio, experiência, processos. modelos de dados, métodos, termplates, entre outros.

Ou ainda, "Reuiso de software é a prätica sistematica de desenvolver ou atualizar novas aplicaçoes a partir de ativos de software pré-construídos nos quais são identificadas similaridades de requisitos e/ou arquiteturas com o que está sendo desenvolvido" (Holanda, Souza, \& Mclo 2000).

Werner \& Braga (2000) apresentam ainda uma outra definiçăo bastante interessante: "Componentes reutilizáveis sāo artefatos autocontidos, claramente identificáveis, que descrevem ou realizam uma funçāo especílica e tèm interfaces claras em conformidade com um dado modelo de arquitetura de software. documentaçāo apropriada e um grau de reutilização definido". Nesta definição, autocontido signilica que o componente desempenha de forma completa a função a que se destina e claramente identificável significa que o componente é facilmente localizável. A questão das inlerfaces também é ressaltada visto que clas são cruciais para o mecanismo de composiçāo de componentes.

Neste trabalho. serão consideradas as très ultimas definiçōes por serem mais completas.

Cabe lembrar que nem sempre é possivel se réutilizar uma solucão em sua totalidade sendo necessário, nesses casos, aplicar somente parte dela na resoluçāo do novo problema. podendo essa parte necessitar de modificacões, adaptações c/ou combinações. Na Engenharia de Softuare esse fato não se altcra. Muitas vezes, adaptações nos componentes se fazem necessárias a fim de atender aos requisitos do sistema. Essas diferentes "formas" de reutilizaçāo de componentes deram origen a seguinte classificaçāo (Holanda, Souza, \& Melo 2000):

Reúso Caixa-Preta Reutilização de componentes sem adaptaçôes;

Reúso Transparente Reutilizaçāo de componentes sem modificaçoes, porém con a necessidade de análise do corpo do componente a fim de se descobrir suas propriedades:

Reúso Caixa-Cinza Reutilização de componentes que sofreram modificaçōes através da configuraçào de parâmetros:

Reúso Caixa-Branca Reutilizaçà de componentes que sofreram reengenharia ou modificacôes no seu corpo. 
Com relação ao modo como os componentes de softuare sāo utilizados, eles podem, ainda, ser divididos em duas classes (Holanda. Souza, \& Melo 2000) :

Componentes Verticais São aqueles reutilizados entre aplicações de mesmo domínio (representam o know-how da organização, capturando conhecimentos especificos do ncgócio);

Componentes Horizontais Sāo aqueles reutilizados entre aplicaçōes de diferentes domínios (representam repetições de elementos de arquitetura, como, por excmplo, uma biblioteca de acesso à bases de dados ou um servico de autenticacãol.

Deve-se considerar também se o alvo do reúso é interno ou externo, ou scja, deve-se identificar se o desenvolvimento de componentes visa o seu uso internamente à organização ou visa a sua oferta a mercados externos.

Segundo Ezram, citado por Iolanda, Souza, \& Mclo (2000), algumas informacoess dos componentes sāo de extrema importancia. Entre elas encontram-se:

- Informaçôes quanto à classificação do componente (facilitam a sua recuperaçāo);

- Descrições e documentaçōes que facilitem a comprecnsão de sua funcionalidade, de como se dá a sua utilizaçăo e de como personalizá-lo:

- Informaçōes relativas à qualidade e testes que facilitem a sua avaliaçāo;

- Informaçōes relativas à sua origem.

Muitas organizacoes acreditam que, ao desenvolverem seus sistemas baseados no paradigma da orientaçāo a objetos, estāo também praticando o reúso. Porém, apenas a orientaçāo a objetos por si só não garante a construção de componentes apropriados para o reúso. A reutilização afeta todas as fases do processo de construção do softuare e. portanto, é preciso que o projeto tenha como objetivo o reúso dos componentes por ele produzidos e seja conduzido sob um processo contendo todas as atividades necessárias para que lais componentes atinjam uma qualidade tal que permita a inclusāo de seus componentes em uma biblioteca (Fichman \& Kemerer 1997: de Sá 1997). Além disso, não se pode olhar para o reủso apenas sob a perspectiva técnica, pois cle cnvolve também a organizaçāo e o encapsulamento de conhecimento e experiencia. e o estabelecimento de mecanismos c. estruturas organizacionais que tornem as organizaçoes disponiveis para sua pratica (Creps, Simos, \& Pricto-Diaz 1992). 


\subsection{Reúso Versus Qualidade de Software}

Segundo a norma ISO 9126, existem alguns fatores, apresentados na Figura 2.1, que sào bastante decisivos na qualidade do softuare. A seguir, è apresentada uma análise de como estes fatores são afetados pelo reúso de componentes (Karlsson 1995).

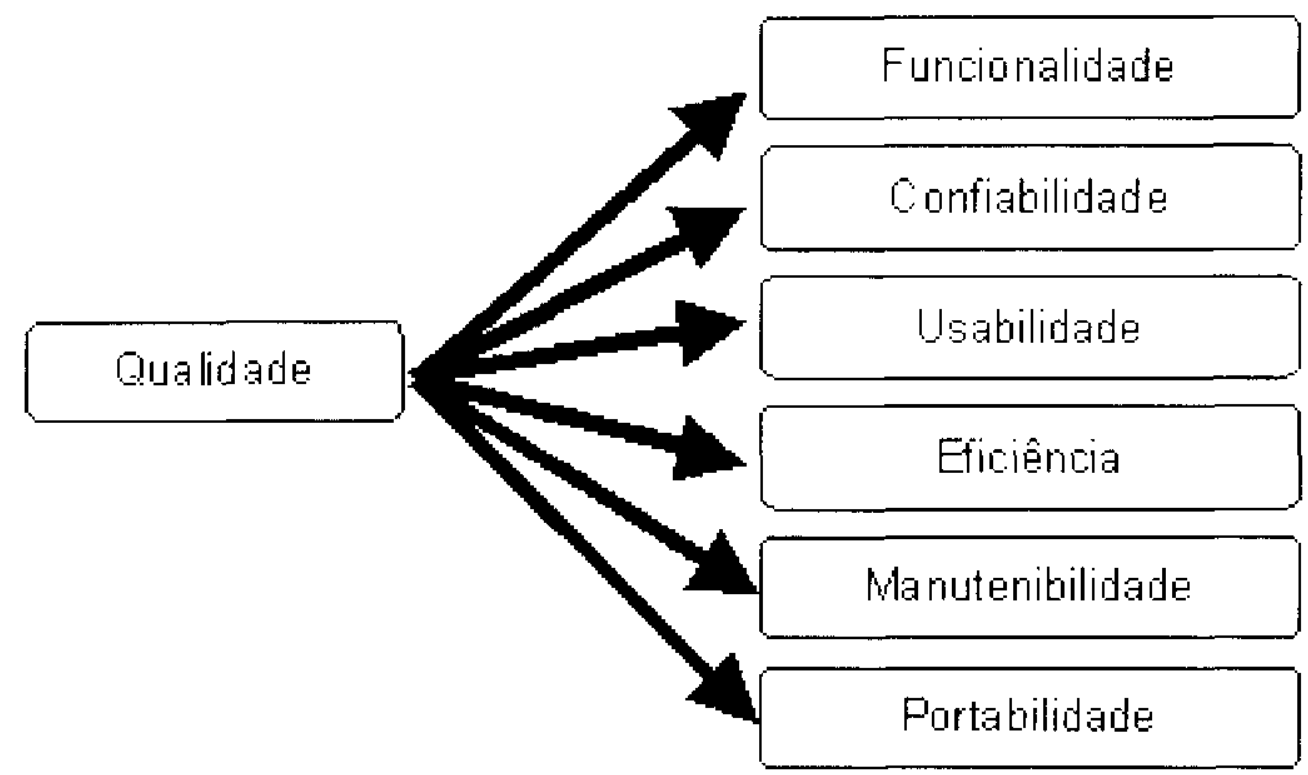

Figura 2.1: Fatores da Gualidade de Software

A funcionalidade dos sistemas baseados $\mathrm{cm}$ componentes de software pode ser melhorada devido à possibilidade de reutilizaçāo de sistemas similares como protótipos para captura dos requisitos funcionais (o que pode otimizar tal funçāo). Alèm disso, o reūso possibilita o descobrimento de requisitos durante a avaliação dos possiveis componentes, a oferta de funcionalidades adicionais e permite que diversos usuários (durante o desenvolvimento de componentes reutilizáveis) discutam o problema, descobrindo mais cedo questōes latentes. as quais, cm outra situaçāo, poderiam somente ser descobertas tardiamente.

Quanto à confiabilidade desses sistemas, esta è aletada de maneira positiva e também negativa pelo reúso de componentes. Como fator positivo pode-se citar o aumento da confiabilidade do sistema devido ao uso correto de componentes bem testados, os quais, quanto mais utilizados menos problemas conterāo. Por outro lado, o uso incorreto ou fora do escopo de um componente, embora bem-testado, constitui-se num risco para o sistema.

A usabilidade do sistema pode ser melhorada pelo uso de componentes já que estes normalmente obtiveram maior dedicação no seu desenvolvimento. No entanto, componentes com características suavemente diferentes podem não ser aceitãveis para um sistema, do ponto de vista da usabilidade. 
Com relaçāo à melhora de eficiência de sistemas baseados em componentes, esta se dá visto que um maior esforço é despendido e justificável na construçāo de um componente eficiente. Alèm disso, componentes especificos podem ser adaptados para necessidades especificas, sendo mais eficientes que componentes genericos.

Quanto à manutenibilidade desses sistemas, esta pode ser melhorada já que muitas das modificaçoes que poderiam ser necessárias jả estão incorporadas ou planejadas nos requisitos de desenvolvimento dos componentes. Ademais, modificaçōes fora do planejado. apesar de serem mais dificeis de implementar, podem, porem, ter o scu custo dividido pelos diversos "reusers" (ou reutilizadores).

Por fim, a portabilidade, por ser um importante aspecto inerente ao desenvolvimento de componentes reutilizáveis, é incorporada naturalmente ao componente.

Além dos fatores de qualidade da ISO 9126 . outros fatores como custo, produtividade e tempo de mercado também são influenciados pela técnica de reúso.

Segundo diversos autores citados por Karlsson (1995), é esperado que o reúso de componentes de software seja uma das maiores fontes de redução nos custos de desenvolvimento nas próximas décadas, basicamente porque ele reduz a quantidade de trabalho.

Jeffrey S. Poulin. citado por Jacobson. Griss. \& Jonsson (1997), a partir da observacão de seis fontes de dados derivou algumas métricas para o reúso. São elas:

- Porcentagem de reúso em um produto;

- Valor agregado pelo reúso taxa de produtividade de uma organização que pratica o reúso comparada a uma que não o faz);

- Ganho de custo resultante do reliso (reflete a redução de custo dos produtos resultante do reuso).

As fontes de dados a partir das quais estas metricas foram derivadas sảo:

- Número de linhas do código-fonte:

- Número de linhas não escritas, mas reutilizadas, incluidas em um arquivo:

- Número de linhas reutilizadas por outros produtos;

- Custo do desenvolvimento de softurare:

- Taxa de defeitos do descrnolvimento de sofiuare: 
- Custo de reparação de defeitos.

Vale ressaltar que o reúso irả aumentar a produtividade desde que haja o reúso da funcionalidade cometa e que o componente seja adequado ao sistema. $A$ utilização de componentes deverá permitir uma redução no tempo de criaçào de planos, modelos. documentos, entre outros. Segundo Pressman (2001), cerca de 30-50\% de reúso resulta em aumento de produtividade na faixa de $25-40 \%$. Vale lembrar que a construção de componentes reutilizáveis exige que um esforço extra seja despendido, podendo assim ser considerado como um investimento a longo prazo.

A reduçāo do tempo de mercado, ou "lead time". aparece como uma forte qualidade da prática do reúso jả que este fator é bastante determinante para o sucesso de um software num ambicnte de constantes mudanças tecnológicas. Desenvolver novos produtos, através da combinaçâo de componentes, é uma maneira de sc reduzir o "lead time".

Em resumo. quatro aspectos sāo amplamente afetados pelo reúso (Rine 1997):

- A incorporação do reu̇so poderá trazer um overhead de cusılo e esforço no desenvolvi mento do módulo que será reutilizado;

- O reuiso poderá melhorar a qualidade do softuare:

- O reúso poderá diminuir o esforço despendido no desenvolvimento de softuare. conseqüentemente aumentando a sua produtividade c diminuindo o custo do sofiware;

- O reúso poderá diminuir o tempo de mercado.

A seguir, cncontram-se alguns casos de sucesso pcla aplicaçāo efetiva do reúso (McClure 1995):

- A Fábrica de Software Toshiba relatou 50\% de reuiso sobre sua linha de produtos cm 1989 e aumentou sua produtividade em 57\%:

- A Divisão de Controles de Sistemas e Comandos da Companhia Hughes Aircraft relatou uma economia de $37 \%$ em custos de projeto na construçāo de dois sistemas num ambiente bascado em reúso;

- A CelciusTech Sustems, Suécia, desenvolveu algumas aplicaçoes como uma familia de sistemas. obtendo mais de $70 \%$ de reúso, dobrando sua produlividade, aumentando sua competitividade e economizando USS 20 milhōes. 


\subsection{O Programa de Reúso em uma Organizaçāo}

A introdução de um programa de reúso nāo é uma tarefa fảcil visto que cnvolve muitas pessoas, processos e questōes técnicas. Muilas organizaçōes têm obtido resultados decepcionantes com o rcúso, justamente por não considerarem todas cstas variaveis. Muitas delas vêem o reúso apenas como uma coleção independente de ferramcntas e técnicas. ou simplesmente abordam o reúso apenas sob o ponto de vísta técnico, deixando de lado as questōes não-técnicas. Para obter bons resultados, as organizaçôes precisam visualizar o reúso como parte integrante de seu processo de desenvolvimento (que deve ser muito bem conhecido) $\mathrm{e}$, dentro deste contexto, tratar das questōes técnicas e não-técnicas envolvidas na prática do reúso (Davis 19931 ${ }^{1}$. Está tarefa, como já citado anteriormente, nāo é fácil.

Assim, torna-se necessãria a criaçāo de um plano de reúso que envolva todas essas questões e consiga ganhar o apoio de toda a organização, e essencialmente o apoio geren cial.

Algumas questōes, classificadas por Schafer. Prieto-Diaz, \& Matsumoto (1994) como questōes chaves de um programa de reúso. serāo tratadas nas Secōes 2.4.1, 2.4.2 e 2.4.3.

\subsubsection{Planejamento do Reúso}

O primeiro passo no planejamento da introduçāo do reúso é verificar a viabilidade de se investir nesta tecnologia dentro da organização. Deve-se considerar a possibilidade de se implantar diferentes tipos c escopos de reúso, dependendo da natureza do negocio e do dominio, e da existencia de processos organizacionais e de software.

O plano de introduçào do reúso deve estabelecer objetivos, escopos e mostrar como as pessoas, o negócio. o processo de desenvolvimento de software e todas as partes envolvidas nesse processo serāo afetados pelo reúso, considerando questoes como orçanento disponivel, retorno desejado e tempo para implantação.

Vale lembrar que os objetivos do programa de implantação do rcúso devem estar sempre relacionados aos objetivos de negócio da organizaçào. Alguns possiveis objetivos desse programa, de acordo com Schafer, Prieto-Diaz. \& Matsumoto (1994), são o aumento da produtividade e da qualidade. a reduçāo do tempo de entrega, a padronizaçào, a interoperabilidade e a compatibilidade de aplicaçōes, novas oportunidades de negócio, entre outros.

${ }^{1} \mathrm{Em}$ (Davis 1993) pode-se encontrar um corljunto de questoes que o autor considera criticas para a melloria da capacidade de reiso. Entre elas aparecen questōes como definição de processo. melhoria contínua, cusı c comprometimento organizacional. 
Um outro ponto a ser abordado neste plano aborda os riscos aos quais a organização estará sujeita, alguns dos quais têm relação com a disponibilidade de tecnologia, a disposiçăo das pcssoas para mudancas, os recursos disponíveis, a estabilidade do dominio e a quantidade de comprometimento da gerência.

Como a introdução do reủso em uma organização a expōe a riscos c custos, é rccomendável que sua prática scja iniciada em projetos de pequenas proporçōes, aumentando o seu escopo conforme o processo de reúso se torne mais maduro. A filosofia por trás desta estratégia é obter alguns pequenos sucessos. observando as questōes organizacionais e técnicas envolvidas, para posteriormente conseguir articular um plano para introdução efetiva do reúso, contanto com o apoio gerencial e dos próprios desenvolvedores.

Segundo Schafer, Pricto-Diaz, \& Matsumoto (1994), na Guinta Convençāo Anual de Institucionalização do Reúso, foram identificados três estágios básicos para introdução do reüso:

1. Introdução, ou comprometimento em tentar praticar o reúso. Nesta etapa o enfoquc deve estar na transferencia de tecnologia, aprendizado e viabilidade de estudo, e na execucão de um projeto piloto. Dentre as atividades a serem realizadas cncontram-se a determinação dos limites do dominio. recomendação de mudanças para o processo de reúso, seleção de um processo de análise de dominio c de um modelo de negócio. Deve-se esperar por resistências e saber como contorná-las;

2. Institucionalização, ou comprometimento $\mathrm{em}$ cxpandir o projeto piloto. $\hat{E}$ nesse momento que o reúso será integrado ao ciclo de desenvolvimento, gerando atividades como: facilitação, trcinamento, suporte, coleta de métricas, registros, relatórios sobre o processo, liçōes aprendidas e provimento de recursos;

3. Manutenção, ou comprometimento em manter c melhorar o processo. Neste ponto o processo de reúso é incorporado totalmente à organização e os esforços para transferência de tccnologia diminuem. Entre as atividades deste estágio aparccem: coletar informaçōes, prover suporte, acessar c otimizar a produçáo de componentes e processos consumidores, e expandir o escopo do programa.

\subsubsection{Questões Organizacionais, Gerenciais e de Pessoal}

Muitas das questoes que influenciam o sucesso de um plano de reúso são culturais. Freqüentemente as pessoas acredilam que o reúso de componentes não funciona, não se aplica ao seu trabalho. nâo funcionará na organizaçào e/ou impede a sua criatividade e 
produtividade. Portanto. muitas vezes as pessoas não estão motivadas nem mesmo a tentar implantar um processo de reuso no seu dia-a-dia.

Assim, conseguir identificar capacidades técnicas e interesses das pessoas envolvidas no processo, o estado cultural e até mesmo educacional destas pessoas. cntre outras informaçòes, c saber articulá-las de mancira a ganhar o seu apoio é extremamente importante na implantaçāo de um programa de reúso (Schafer, Prieto-Díaz, \& Matsumoto 1994).

É sabido que o comprometimento gerencial é um fator detcrminante para o sucesso de qualquer tipo de implantaçāo de novas tecnologias em uma organização. Com o reúso, este fáto não se altera. Portanto, faz-se necessário despender quanto esforço for preciso para garantir o apoio da equipe gerencial ao programa de reúso.

Para Schafer, Prieto-Diaz, \& Matsumoto (1994), alguns elementos importantes para convencer tal setor são:

- Vender o reuso como um conceito suficientemente maduro para exploraçāo;

- Mostrar outras organizaçōes semelhantes com significantes programas de reúso, principalmente aquelas que apresentam beneficios competitivos e conómicos advindos destes programas;

- Relatar beneficios e linhas gcrais de custos;

- Analisar os riscos c apresentar um plano factivel;

- Assegurar que todos os gerentes relcvantes estāo convencidos.

Como citado anteriormente. muitas pessoas dentro da equipe de desenvolvimento (dentre estes, engenhciros c programadores) possivelmente se mostrarão nāo favoráveis à introduçāo do reúso na organização. Isto porque muitos deles acredilam que este novo modelo de desenvolvimento trará impactos $\mathrm{cm}$ confiabilidade, eficiència, suporte, entre outros. Além disso. é de extrema valia que as pessoas cnvolvidas no programa concordem com algumas definiçōes básicas tais como "reúso", "reusabilidade". "componente", "produtor de componentes". "consumidor de componentes". entre outros. É importante tambćm que os "produtores de componentes" saibam como desenvolver componentes reutilizávcis c que os "consumidores de componentes" saibam como utilizar componentes reutilizáveis no seu descnvolvimento.

A chave para resolver tais problemas está no treinamento. A realização de cursos relacionados a conceitos básicos, pesquisa/utilizaçāo/avaliaçāo de componentes. construção 
de componentes e manuseio do repositório é bastante importante para uma boa aceitação e a correta/real implantaçāo das atividades do modelo de desenvolvimento baseado em componentes. O nivel de treinamento de cada desenvolvedor dependerá da sua funçāo no projeto, porém todos precisarāo de um trcinamento básico.

\subsubsection{Questöes de Domínio, Processo e Técnicas}

Quando se fala em reuso, a idéia é que pode-se reutilizar "quase tudo", ou seja, pode-se ter diversos tipos de componentes que serão reutilizados, cada um pertenccnte a um nivel de abstração.

Uma decisāo chave estã em escolher qual será o escopo de reu̇so abordado no programa. ou seja, se deseja-se reutilizar componentes independentes de dominio (gerenciadores de lista, funçōes matcmática, entre outros), componentes dependentes de dominio ou componentes dentro de uma família específica de aplicaçōes, como uma linha de produto (semàntica de componentes baseada em tipos de aplicações especificas). Além disso, deve-se considerar também se o alvo do reúso é o fornecimento de componentes apenas para a própria organizaçāo ou para mercados externos.

Independente do tipo de reúso a ser implantando, certamente surgirá a necessidade por um processo de software que suporte a sua utilização. Este novo processo deve incluir tarefas para a produçāo, análise e recuperaçāo de componentes, a análise de dominio. tarefas relacionadas às bibliotecas ou repositórios. suporte, manutenção e certificação do componentes.

Com relação à obtenção dos componentes, estes podem ser obtidos através da reengenharia de sistemas, pelo seu desenvolvimento ou através da compra. Questōes relacionadas a custo, certificação $c$ direitos legais devem ser consideradas ao se optar por uma dessas fontes de componentes.

O plano de introdução do reúso terả de determinar o tipo de tecnologia disponível e necessária, e garantir que esta tecnologia seja consistente com a tecnologia de informaçāo e estratégia técnica utilizadas na organização

Com relação ao repositório, deve-se desenvolver uma estrutura que considere questōes como: quantidade de bibliotecas a serem disponibilizadas, processos de atualização c distribuição, o acesso à biblioteca. formatos, seleçāo de documentos. entre outras. 


\subsection{Atividades Especificas do Processo de Desenvolvimento de Soft- ware com Reúso}

A introdução do reúso no processo de desenvolvimento de softuare implica na cxecução de uma séric de novas atividades. Segundo Karlsson (1995), algumas destas atividades sào:

Identificação dos Requisitos de um Componente: consiste ná compreensāo da aplicaçào e na determinaçäo dos componentes que poden ser utilizados para implementar a solução. Esta atividade deve ocorrer em cada fase do desenvolvimento.

Diretriz: Utilize diferentes níveis de abstraçāo para os requisitos, dependendo da fase do desenvolvimento. Por cxcmplo, na busca por componentes de alto nível, os requisitos devem ser tão genéricos quanto possível enquanto que na busca por componentes de baixo nivel. o uso de requisitos específicos é mais eficiente.

Busca por Componentes: consiste na recuperacào de um conjunto de componentes que satisfaçan os requisitos identificados. Este conjunto deve ser grande o suficiente para que soluçōes alternativas sejam identificadas e a melhor seja posteriormente selecionada.

Diretriz: O escopo da busca deve ser o mais amplo possivel dentro da organização, e nāo deve-se ignnorar fontes de componentes externas à organizaçāo.

Diretriz: Utilize, no cspaço de busca, termos definidos na organização.

Compreensão dos Componentes Recuperados: consiste na compreensão dos aspectos tanto funcionais (funcionalidade oferecida) como nāo-funcionais (qualidade, portabilidade, eficiência, cntre outros) dos componentes recuperados.

Diretriz: Utilize a visāo apropriada do componente para entendè-lo ldifcrentes indi viduos utilizam visōes diferentes para compreender o componente). Umá combinação de visões e um método classificado como poderoso na melhora da compreensibilidade do software (Karlsson 1995).

Diretriz: Utilize o resultado da análise de dominio ${ }^{2}$. se disponivel, para compreender as características de um componente.

\footnotetext{
${ }^{2}$ Estudo e formalizacáo do conhecimento do dominio. Atividade especifica do desenvolvimento de conponentes reutilizáveis (Karlsson 1995).
} 
Diretriz: Consulte pessoas experientes, especialmente os especialistas no dominio, os desenvolvedores do componente coutros profissionais que já tenham reutilizado o componente.

Diretriz: Realize um cstudo completo de um componente de alto nivel de maneira a compreendē-lo totalmente e fazer escolhas apropriadas. se o cronograma permitir. Componentes de alto nivel. como por excmplo um framework, podem determinar todo o funcionamento da aplicaçăo e não devem ser selecionados sem um extenso estudo de seu funcionamento e limitações.

Investigue Adaptações: Uma vez, conhecidos os componentes recuperados, devem ser investigadas possiveis adaptaçoes (e o custo das mesmas) para atender aos requisitos desejados.

Diretriz: Determinc o nivel apropriado de investigação (inlormação necessária) dos componentes com base no lipo do componente c dos requisitos a serem satisfeitos.

Diretriz: Deve-se estudar as soluçōes tecnicas para implementar as adaptaçōes necessarias de acordo com o tipo de reuso (caixa-preta, caixa-branca. entre outros) escolhido.

Diretriz: Avalie a distância, tanto no aspecto de requisitos funcionais como nàofuncionais. entre os componentes candidatos cos requisitos da aplicacão.

Diretriz: Quando a avaliaçāo das diferenças for realizada através de modelos baseados em métricas. considere os diferentes níveis: métricas, critérios e fatores.

Diretriz: Não sc esqueça de cstudar as adaptações necessárias para integrar o componcnte à aplicaçào.

Seleçāo do Componente: Consisı na escolha de uma solução dentre as possivcis. utilizando os componentes candidatos, considerando fatores economicos, de qualidade, futuros objetivos do reúso, entre outros.

Diretriz: Na seleção dos componentes, opte por componentes padronizados, na ausencia de outros criterios.

Adaptação e Integração dos Componentes: consistc na implementação das adaptações necessárias e na integração do componente à aplicação.

Diretriz: Utilize um prefixo referente ao projeto ou módulo para cada nome.

Diretriz: Defina um protocolo de comunicação padronizado. 
Diretriz: Guando fizer adaptaçōes de um componente em uma determinada fase. não se esqueça de dar seguimento a clas nas fases seguintes.

Comunicação do Reúso de um Determinado Componente: consiste ná confecção de um relatório informando que um determinado componente foi reutilizado (ou tentou-sc fazê-lo). Esta atividade aumentarả a reusabilidade do componente por manter junto à sua documcntação, a experiència deste esforço de reúso (através de informaçōes como a descrição do ambiente de reuso, os problemas encontrados. especialmente ná compreensão. integraçao e adaptação do componcnte, e o quanto esta atividade foi custosa).

\subsection{O Repositório de Componentes}

Para que a prática do reúso possa ser efetivamente aplicada é necessário que todos os membros da organizaçāo que utilizam componentes reutilizáveis tenham conhecimento dos componentes disponiveis, possam avaliá-los c. se possivcl, reutilizá-los cm novos projetos.

Alèm disso, é preciso que os componentes sejam inspecionados quanto à sua adequacão aos critérios de validaçào c ao controle de qualidade previamente estabelecidos na orßánizaçāo. Esta funçāo pode ser realizada por um bibliotecário, responsável também por conhecer os componentes, por manter a consistência do repositório, por não permitir que componentes com a mesma funcionalidade sejam desenvolvidos mais de uma vez, entre outras atividades (Fichman \& Kemerer 1997).

Depois de inspecionados, esses componentes devem entāo ser armazenados de mancira a pernitir uma pesquisa e recuperação eficientes que estimulem a consideração de sua utilizaçào em novos projetos. Este armazenamento, pesquisa c recuperação sāo funçōes pertencentes ao repositório de componentes ou bibliotecas de reutilizaçăo. Em Ide Sá 1997). uma definição um pouco mais ampla é dada para as bibliotecas de reutilizaçăo (incluindo também a atividade de certificaçāo descrita acima, por exemplo): "Organizaçōes compostas por pessoas, procedimentos e ferramentas direcionadas a facilitar a reutilização de componentes, atendendo às metas de custo e produtividade".

Entre algumas das principais funcionalidades esperadas de um repositório pode-se citar (Holanda, Souza, \& Melo 2000):

Identificação e Descrição Trata da identificação e descriçāo do componente a partir de um conjunto de caracteristicas (nome, palavra-chave etc) que o difercncia de outros; 
Inserção Trata da inserção de novos componentes ou novas versōes de antigos componentes no repositório, por usuários autorizados;

Exploração de "Catâlogo" Os usuários de um repositório devem poder analisar um "catálogo" de componentes a fim de conhecer c analisar os componentes disponíveis. Esla funcionalidade é suficiente para localizar componentes em um repositório que contenha uma pequena quantidade dos mesmos;

Pesquisa Textual Os usuários devem poder realizar pesquisas mais específicas na descri çào dos componentes;

Recuperação Os usuários devem poder recupcrar um componente;

Organização e Pesquisa Os componentes devem ser organizados de mancira a possibilitar a sua pesquisa através de palavras-chave, atributos, sinônimos, entre outros:

Histórico O repositório deve armazenar informaçōes de uso, modificaçôes, criaçāo e ex clusão de cada componente:

Controle de Acesso O repositório deve implementar uma política de segurança para que determinadas funcionalidades só possam ser executadas por pessoas autorizadas:

Controle de Versōes O repositório pode conter várias versōes de um componcnte e deve deixá-las disponiveis para recuperação;

Controle de Mudanças É recomendável a existència de procedimentos para solicitação de alteraçōes, discussōes e permissōes para as solicitaçōes, a fìm de manter a consistência do repositório;

Notificação de Mudanças O repositório pode prover funções que notifiquem todos os scus usuários de alteraçoes sofridas no mesmo, tais como inclusão de novos componentes, disponibilizaçāo de novas funcionalidades, entre outras.

\subsubsection{Técnicas de Classificaçāo de Componentes}

A busca por um componente com as caracteristicas que se deseja não ć uma tarefa simples. Isto porque esta atividade envolve a realização de uma pesquisa em descriçoes heterogêneas dentro de um grande espaço de busca (de Souza. Costa, Braga, Matoso, \& Werner 2001)

Assim. o repositório de componentes não pode ser apcnas um local onde todos os componentes estāo armazcnados. sem nenhuma organizaçāo baseada $\mathrm{cm}$ seu conteủdo. É 
preciso que este armazenamento seja feito de modo a permitir uma localizaçăo rápida de componentes relacionados ou desejados. Esta busca cficiente por componentes cstá intrinsecamente ligada à qualidade dos mecanismos de classificação utilizados no armazenamento dos componentes.

A seguir, serão descritas quatro ténicas, consideradas simples, que permitem a classilicaçào dos componentes, além de uma breve análise do processo de escolha da técnica a ser utilizada. Estas descricoese e esta análise tomam como base as proposicôes de Coulange (1998).

\section{Palavras-Chave}

Esta é uma ténica cuja implementacão é considerada simples. Fla consiste na associação de algumas palavras-chave a cada componente, tomando como base a sua descrição.

Basicamente, na busca por componentes, o desenvolvedor fornece algumas palavras que ele julga pertinentes ao tipo de componente desejado. Estas palavras serão entāo procuradas na descrição de cada componente. Os componentes nos quais estas palavras foram encontradas irão dar origem a uma lista que seráa apresentada ao descruvolvedor.

Como já foi dito, esta técnica é bastante simples, porém, muitas vezes, cla apresenta ao desenvolvedor resultados ruins. Isto se deve a inumeros fatores, tais como, tempos verbais, possiveis erros gramaticais. sinonimos, entre outros. Todavia, muitas vezes estes problemás podem ser facilmente contornados, pelos próprios desenvolvedores dos componentes ou pelos que estão a busca deles, os quais podem fornecer apenas a raiz da palavra, podem procurar pelos sinonimos das palavras, as descriçōes dos componentes podem passar por corretores ortográticos, entre outras opçōes.

\section{Palavras Caracteristicas}

Esta técnica ć bastante semelhante à anterior. A diferença presente nela é que a cada palavra que pode ser usada na busca é associado um peso. Para palavras que aparecem nas descriçōes de todos os componentes, e que, portanto, nāo são seletivas, è associado peso zero. Para palavras mais seletivas, pesos maiores são associados.

Durante a busca, c analisada a existencia das palavras apresentadas pelos desenvolvedor que nảo tem peso zero nas descrições dos componentes. Pará cada componente encontrado a associado um peso correspondente a soma dos pesos das palavras encontradas na sua descrição. Os componentes sāo apresentados aos desenvolvedores orderiados por seus pesos. 
Certamente o resultado aprescntado aos desenvolvedores irá conter componentes de maior relevância do que a técnica anterior. Porém, esta técnica possui algumas desvantagens, além das apresentadas na técnica baseada em palavras-chave. Entre cstas desvantagens pode se apresentar a necessidade de se recalcular os pesos das palavras a cada componente inscrido no repositório, a necessidade de existência de um dicionärio que contenha os pesos de cada palavra e os componentes associados a ela, entre outros.

\section{Classificação Hierárquica}

A classificação hierárquica tem como objetivo estruturar o repositorio com basc cm alguns "temas", c possivelmente sub-temas, nos quais os componentes seriam classificados.

Um dos problemas desta técnica é como classificar um componente ao inserí-lo no repo sitório, ou seja, sob qual tema ele scrá procurado c, portanto, deverá ser armazcnado. Para resolver este problema, pode-se armazenar o componente sob diversos temas, sendo assim mais fácil de um descnvolvedor encontrá-lo. Porém, ainda scrá neccssảrio que se imagine todos os temas nos quais será possivel que um desenvolvedor busque por um componente.

Também nào é recomendável que existam muitos componentes em cada tema terminal. Assim, para repositórios muito extensos, pode ser necessária a existência de muitos temas e sub-temas. Por outro lado, não é recomendável que o caminho (seqüència de temas e sub-temas) a ser percorrido para encontrar um componente seja muito longo, já que pode ser necessária a busca em mais de um caminho para encontrar o componente desejado.

\section{Facetas}

Esta técnica foi proposta por Pricto-Díaz e é um melhoramento da classificaçāo hierãrquica.

Pode-se imaginar que cada componente scja relacionado a diferentes aspectos, chamados de facetas por Prieto. A cada uma destas facetas, diversos termos sāo associados. No repositório, cada termo de cada faceta scrá associado aos componentes a que se refercm.

Durante a busca, o descnvolvedor fornece os termos correspondes ao que deseja encontrar para cada faceta. Serāo retornados os componentes associados aos termos fornecidos. ordenados pelo máximo de termos no máximo de facetas.

O maior problema desta técnica é a dificuldade de determinar as facetas e os termos de cada faceta. Esta dificuldade é ainda agravada conforme o repositório cresce. tornando-se cada vez mais dificil estender a classificação. Isto porque, cada vez que um novo com ponente é inserido no repositório, novos termos tèm de ser inseridos nas facetas e, con- 
seqüentemente, todos os outros componentes deverão ser revisados para verificar se eles estão ou não relacionados com este novo termo.

\section{A Escoina da Melhor Técnica}

Como pode ser percebido, todas as técnicas tèm vantagens e desvantagens e nenhuma delas é universalmente melhor. Para escolher qual delas utilizar, deve-se analisar cuidadosamente as necessidades e as possibilidades da organização, e a viabilidade c as características de cada técnica c de uma mistura delas. Só então, com todas estas informaçoes em mãos, uma organização estará apta para escolher qual delas (ou quais delas) melhor se adapta(m) às suas necessidades.

\subsection{Caracterizaçāo de Componentes}

Para que se possa compreender. classificar, usar corretamente os componentes é essencial que sejam disponibilizadas algumas informaços sobre eles, em outras palavras, é essencial quc des scjam caracterizados. Uma boa caracterização possibilita uma meIhor catalogação dos componentes, melhor recuperação, uso e comprecnsão dos mesmos (Yacoub, Ammar, \& Mili 1999: Werner \& Braga 2000).

Foram propostas por Yacoub, Ammar, \& Mili (1999) algumas informacoes para compo sição de uma boa caracteizaçäo de componentes. Segundo este autor, estas informaçôs auxiliam na compreensão dos diferentes tipos de componentes que podem estar disponi veis, como eles estāo envolvidos no ciclo de vida, como são reutilizados e que tecnologias sāo necessárias para sua adoção.

As informaçoes para caracterização de componentes, propostas por Yacoub, Ammar, \& Mili (1999), são classificadas em très categorias:

Descrição Informal Descreve questōes dos componentes relacionadas às pessoas e cngloba as seguintes informaçòes:

- Idadc: reflete a estabilidade e maturidade do componente;

- Fonte: referc-se à fonte fornecedora do componente fCO'TS - Commercial Off The Shelf. GOTS - Government Off The Shelf, ou ainda a própria organizaçāo)

- Nivel de Reúso: descreve em quais fases do ciclo de vida o componente pode ser usado (fator fortemente influenciado pela natureza do componente, tratada nesta mesma seçào, página 23):

- Contexto: descreve as situaçōes nas quais o componente pode ser usado; 
- Propósito: descreve o propósito para o qual este componente está sendo documentado (inclui o problema, ou conjunto de problemas. que o componente se propõe a resolver, ou participar da resolução);

- Componentes Relacionados: define outros componentes conhecidos que resolvam os mesmos problemas ou problemas similares.

Informaçāo Externa Descreve as interaçōes do componente com outros artefatos da aplicação ou com outras plataformas. Engloba os seguintes itens:

- Interoperabilidade: descreve como o componente interage com outros componentes do mesmo sistema, mostrando inclusive como cle deve ser invocado;

- Portabilidade: descreve como o componente interage com a plataforma, especificando também com quais plataformas o componente pode ser usado e como transportà-lo para outras plataformas:

- Papel (Role): identifica o que o componente fornece para os outros artefatos da aplicação e o que ele exige deles. Um componente pode desempenhar um papel ativo ou passivo. No primeiro caso, o componente afeta e é afetado por outros artefatos. No segundo, o componente c afetado ou invocado por outros artefatos. Esta informaça é importante para que se determine qual componente está no controle da aplicação $\mathrm{cm}$ um dado momento. facilitando a resolução de problemas de controle:

- Fase de Integração: refere-se a quando o componente è integrado ao sistema. Existem duas possibilidades para este item: integração em fase de desenvolvimento ou integração run-time. Na primeira o componente é inserido na aplicação e compilatdo com ela, enquanto que na segunda o componente é (des)carregado da aplicação on-line;

- Frameuorks de Integração: algumas vezes, quando integrado a uma aplicação, o componente não interage dirctamente com ela, mas sim através de um framework. Nestes casos, é preciso que se especifique o framework sobre o qual o componcnte está trabalhando:

- Tecnologia: especifica a tecnologia da qual o componente depende e as restricóes tecnologicas para que ele seja descnvolvido e reutilizado. Vale lembrar que existem componentes que podem ser independentes de questōes tecnológicas les- 
pecificações de requisitos, por exemplo), tornando-se, nestes casos, dispensável a apresentaçāo desta informação:

- Caracteristicas Não-Funcionais: para alguns tipos de componentes pode ser necessário especificar algumas caracteristicas não-funcionais, tais como questôes de segurança, de performance e de confiabilidade.

Informação Interna Descreve aspectos internos do componente, englobando:

- Natureza: determina em que fasc do processo de desenvolvimento o componente pode ser usado. Geralmente, os componentes são classificados pela sua natureza nas seguintes categorias: Componentes de Especificaça, Componentes de Pro. jeto (principio ou ideia de projeto como, por exemplo, design paterns (Gamma, Helm, Johnson, \& Vlissides 1995)\}, Executäveis e Código-Fonte;

- Granularidade: classificacào do componente com relação a algum tipo de granularidade, como, por excmplo. tamanho do componente;

- Encapsulamento: encapsulamento de decisōes. sejam elas de projeto, implementação ou especificação;

- Aspecto Estrutural: descreve a estrutura interna do componente, ou seja, os itens que compõem um componente e como eles se relacionam. Esta caracteristica c importante para macro-componentes, isto $\dot{e}$, grandes componentes que cnvolvem outros menores:

- Aspecto Comportamental: define dois aspectos: como o componente reage a determinados conjuntos de atributos e como o componente responde a uma seqüência de ações;

- Acessibilidade ao Código-Fonte: determina se o código-fonte do componente esla disponivel. Esta disponibilidade determina a acessibilidade e modificabilidade do componente.

\subsection{Padrões e Critérios de Qualidade para Componentes}

Como já foi citado anteriormente, é importante que os componentes sigam alguns padrōes e obedecam a alguns critérios de qualidade a fim de garantir a compreensibilidade e qualidade dos mesmos.

Segundo de Sá (1997), cxistem padrōes c regras para código-fonte, estabelecidas por organizaçöes comerciais e governamentais. Entre os topicos abordados por essas regras c 
padrões aparecem a independência de dados, a generalidade, a confiabilidade, a manutcnibilidade, a portabilidade, a robustez, a complexidade, a legibilidade, a modularidade c a abstração de dados.

Porém, por não ser somente o reúso de código o objetivo de um programa de introdução do reuiso de maneira cfetiva na organização, todos os itcns que serão alvo da reutilização devem ter regras e padrōes estabelecidos para scu descnvolvimento. Desta mancira, será possivel assegurar que todos os componentes do repositório atendem às expectativas $\mathrm{e}$ a demanda dos usuários. Além disso. esses padrōes e regras estarāo incentivando um desenvolvimento eficiente e promovendo a melhoria do processo de desenvolvimento (de Sá 1997).

Em um estudo de caso apresentado por de Sá (1997), foram cstabelecidos os seguintes critérios mínimos de qualidade:

1. Critérios relacionados ao código:

- Gualidade da Documentaçāo (documentação $\mathrm{cm}$ conformidade com padrōes estabelecidos para legibilidade, compreensibilidade e compatibilidade);

- Completitude (referência para todos os itens ou módulos necessários);

- Consistência fconformidade com padrões definidos e com as definiçōes do usuá rio);

- Manutenibilidade (facilidade de modificaçāo):

- Confiabilidade (baixa taxa de erros);

- Aplicabilidade (relevãncia do componente no dominio da aplicação).

2. Critérios relacionados a outros produtos do ciclo de vida:

- Passar por reuniòes de inspeção;

- Ser relevante no domínio:

- Ser completo c independente de outros componentes do mesmo lipo.

3. Criterios relacionados ao conhecimento

- Ser relevante no dominio:

- Scr disponibilizado através de biblioteca. 


\subsection{Consideraçōes Finais}

Neste capiluto, foram abordados diversos aspectos, cilados ná literalura. envolvendo o reuso de componentes. Alguns destes aspectos sāo considerados na estratégia de implantaça do reúso de componentes no processo de desenvolvimento de softuare desenvolvida nestc trabalho

Outro fator considerado nessa estrategla refere-se a dificuldade em implantar diversas mudanças de una só vez na organizaçāo. Assim, tal estratégia propōe a introduçào de methorias no processo de desenvolvimento de softuare de uma maneira gradativa e continua. Por esta razāo, a melhoria continua do processo de desenvolvimento de softuare ć o tema abordado no próximo capitulo. 


\section{Capítulo 3}

\section{Melhoria de Processo de Desenvolvimen- to de Software}

\subsection{Considerações Iniciais}

A implantação do reúso no processo de desenvolvimento de software envolve mudanças cm diversos aspectos da organização. como processos. técnicas e até mesmo cultura organizacional. Assim, a estratégia para tal implantaçāo apresentada neste trabalho propõe que a implementação de todas estas mudanças ocorra de maneira integrada, gradlativa e continua.

Existem diversos modelos que orientam as organizaçōes para que as mesmas sejam bem-sucedidas na melhoria continua de seu processo de desenvolvimento de sofiware. $O$ IDEAL, apresentado neste capitulo, é um desses modelos.

\subsection{O ModelO IDEAL}

O Modelo IDEAL foi desenvolvido pelo SEI (Software Engineering Instiiute) e:

- Permite que se compreenda qual é o estado atual do processo de desenvolvimento de sofitware;

- Permite que se desenvolva uma visão do processo que se alneja alcançar (ou seja. a melhoria que se deseja implantar);

- Auxilia no estabelecimento de uma lista de açōes, em ordem de prioridade, necessári as para se alcançar tal melhoria; 
- Auxilia na geração de um plano para acompanhar as ações e alocação de recursos para a execuçāo deste plano.

O IDEAL (versão 1.1) é um acrônimo que engloba cinco fases do ciclo de melhoria de processo de software (Fiats 2000):

Initiating (Inicializaçāo): Nesta fase deve-se identificar os estimulos para as mudanças, estabelecer o contexto sob o qual o trabalho será realizado, assegurar o comprometimento dos patrocinadores e definir uma infra-estrutura;

Diagnosing (Diagnóstico): Nesta fase deve-se caracterizar dois estados da organizaçăo: o estado atual do processo de software e o estado futuro desejado para o processo de software. Deve-se também desenvolver recomendações relacionadas a como proccder nas atividades subseqücntes;

Establishing (Estabelecimento): Nesta lase deve-se desenvolver um plano detalhado do trabalho. São abordadas questōes como prioridade de alleraçōes, recursos disponíveis, responsabilidades. entre outras;

Acting (Açāo): Nesta fasc deve-se implementar o trabalho que foi contextualizado e plancjado até o momento. Aborda questōes como criação da solução. teste da mesma através de um projeto piloto, melhoria da soluçào bascada nos resultados dos testes cfetuados e implemcntaçāo da soluçāo por toda a organização;

Leveraging (Liçōes): Nesta fasc a experiencia adquirida é revista para identificar quais metas definidas na fase de inicialização foram satisfeitas e como a organização pode implementar melhorias mais eficientemente no futuro. Esta fase contempla um dos objetivos do IDEAL - realizar a melhoria contínua na capacidade de implementação de mudanças.

\subsection{Fases do Modelo IDEAL}

Como citado anteriormente, o modelo IDEAL é composto por cinco fases, as quais são melhor detalhadas nas próximas seçôes. Na Figura 3.1 c apresentada a forma como cstas fascs estāo dispostas a fim de obter a melhoria contínua objetivada pelo IDEAL. 


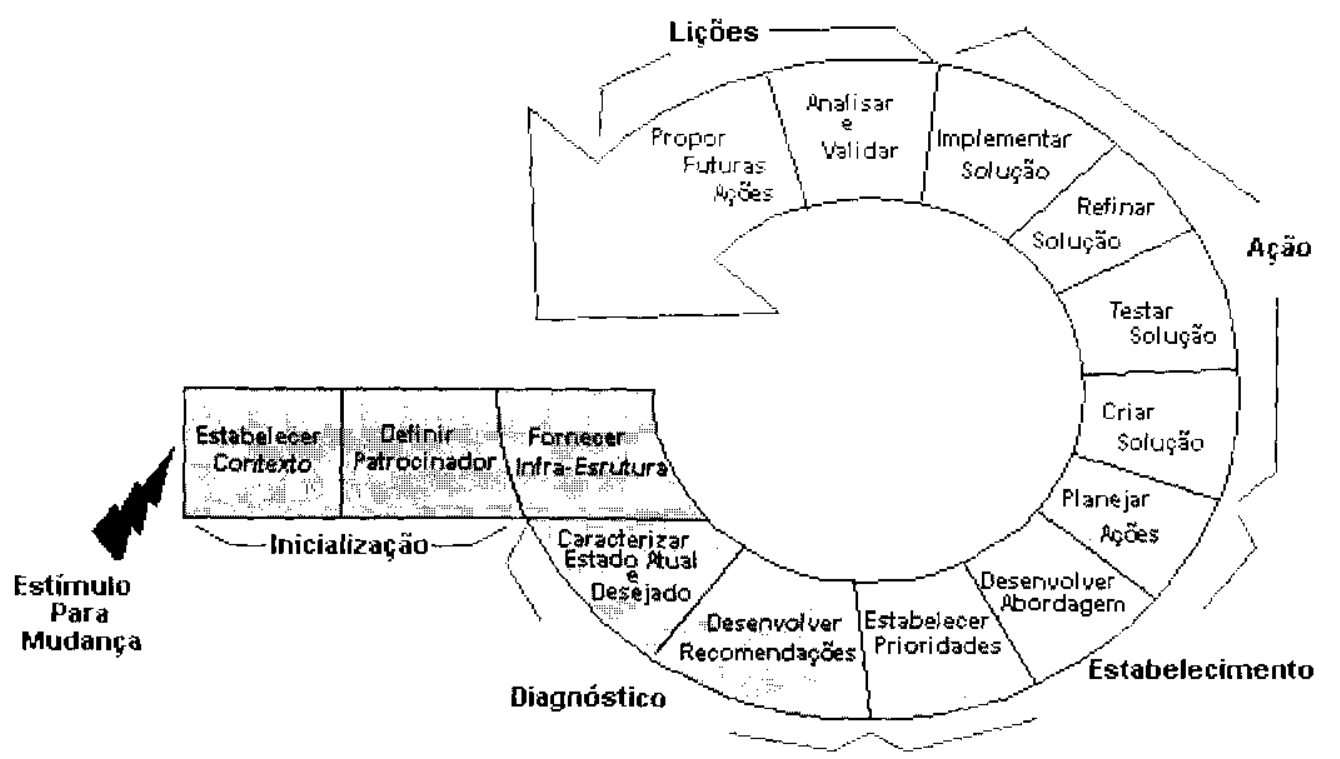

Figura 3.1: O Modelo IDEAL (Gremba \& Myers 1997)

\subsubsection{Fase de inicialização}

Nesta fase é realizado um trabalho de preparaçāo para a implantaçāo da melhoria, sendo, portanto, uma fase critica. A não completitude de suas atividades pode ser decisiva para o fracasso do processo de melhoria.

As atividades que compōem a fase de inicialização são (Gremba \& Myers 1997; Fiats 2000\}:

Estímulo para Mudança Sāo definidos os motivos, as necessidades de negócio que alavancaram as mudanças nas präticas da organizaçāo. Entre os possiveis estímulos aparecem eventos inesperados, ordens de superiores ou informaçōes de benchmarking. Gualquer que seja, o estimulo pode ter grande influência na conduçào, visibilidade e sucesso dos esforços para mudança. Em geral, quando a necessidade de melhoria surge por razões de negócio são maiores as chances de sucesso, visto que é mais fácil convencer a organização, como um todo, de sua importancia.

Estabelecer Contexto Identificados os estimulos para mudança, a gerência da organizacão deve estabelecer o contexto do trabalho que será realizado. Esta atividade envolve a definição de como os esforços se enquadram na estratégia de negócio da organização, quais metas e objetivos da organizaçāo serāo satisfeitos, como serão afetadas outras iniciativas e trabalhos futuros, quais sāo os beneficios esperados, entre outras 
questōes. O contexto e as implicaçōes do processo de mclhoria scrāo melhor percebidos conforme os trabalhos forem encaminhados. No entanto, é importante que tais questões estejam definidas, da mancira mais clara possivel, antes de iniciar os esforços.

Definir Patrocinador Um patrocinador cfetivo è um dos fatores mais importantes do processo de melhoria. Sua funçāo é ajudar a manter o compromisso nos momentos difíceis e, principalmente, no inicio do processo, quando a organização pode-se encontrar em uma situaçāo de caos. Além disso, o patrocinador é responsável por garantir que os recursos essenciais estejam disponiveis durante a melhoria.

Fornecer Infra-Estrutura Uma vez que as razóes para mudança e o contexto dos trabalhos estāo definidos e os patrocinadores comprometidos com os esforcos. faz-se necessäria a definiçāo de mecanismos para gerenciar os esforços de implementaçāo - a infra-estrutura. Esta infra-estrutura pode ser temporária ou permanente, e seu tamanho e complexidade são fortemente dependentes da natureza da melhoria. Fornecê-la envolve desenvolver um contrato que documente e esclareça as expectativas, e descreva as responsabilidades.

\subsubsection{Fase de Diagnóstico}

Esta fase desenvolve uma maior compreensāo do processo de melhoria a ser realizado através da caracterizaçāo de dois estados: atual e desejado. A partir desta caracterizaçāo sāo desenvolvidas recomendaçōes de como proceder nas atividades subseqüentes.

As atividades que compōem está fase sāo (Gremba \& Myers 1997):

Caracterizar Estado Atual e Desejado Esta atividade ć similar a identificar o inicio e o fim da jornada. A verificação do estado atual do processo é feita através de uma avaliaçāo do mesmo. ou seja, através do levantamento de informaçoes que descrevam a capacidade atual e real do processo. Como resultado desta avaliação tem-se os pontos fortes e fracos da organizaçào, a partir dos quais sāo definidas as atividades cuja melhoria é prioritária (Fiats 2000). Para estabelccimento do estado desejado podem ser usados modelos de referencia. Vale ressaltar que esta atividade deve estar focada nos elementos críticos relacionados à melhoria, e nāo cm todos os aspectos da organização.

Desenvolver Recomendações Nesta atividade sāo desenvolvidas recomendaçôes relativas à maneira como proccder nas atividades subsecüentes. Por ser desempenhada, geral- 
mente, por pessoas experientes ou especialistas, suas recomendaçōes sào fortemente consideradas nas decisōes tomadas por gerentes e patrocinadores.

\subsubsection{Fase de Estabelecimento}

O objetivo desta fase é desenvolver um plano detalhado de trabalho. Com base nas recomendaçōes advindas da fase anterior e nas restriçōes da organização, sảo detiniclas prioridades e uma abordagem que contemple cstes fatores e prioridades. Por fim. sāo definidas e incorporadas ao plano de açào responsabilidades, prazos, produtos liberávcis $\mathrm{c}$ açōes especificas.

Esta fase è composta pelas seguintes atividades (Gremba \& Myers 1997):

Estabelecer Prioridades Esta atividade é responsável por desenvolver prioridades para os esforços de mudança, levando em consideração fatores como limitação de recursos. dependências entre atividades, fatores externos e prioridades globais da organização.

Desenvolver Abordagem A partir do maior conhecimento do escopo do trabalho fobtido com a fase de diagnósticol e do conjunto de prioridades, pode-se definir uma abor dagem de acompanhamento do trabalho e identificar a disponibilidade de recursos. Tal abordagem deve considerar fatores técnicos, como pormenores da instalação da nova tecnologia, novas habilidades e conhecimentos necessários para o uso da nova tecnologia, e fatores nào-técnicos, como cultura organizacional, fontes de resisténcia, niveis de patrocinio e forças de mercado.

Planejar Ações Definida a abordagem. deve-se desenvolver um plano detalhado de implementação. Este plano deve conter cronograma, recursos, pontos de decisāo, responsabilidades, mecanismos de acompanhamento, riscos, estratégias e quaisquer outros elementos requeridos pela organização.

\subsubsection{Fase de Açāo}

Nesta fase, o trabalho que foi contextualizado e planejado nas fases anteriores, é implementado.

As atividades realizadas nesta etapa são (Gremba \& Myers 1997):

Criar a Solução Esta atividade tem o objetivo de reunir e associar todos os elementos chave. tais como ferramentas, processos, conhecimentos, entre outros, a fim de criar a melhor solução destinada às necessidades organizacionais previamente definidas. Esta soluçāo normalmente é criada por um grupo técnico. 
Testar a Solução Uma vez criada. a soluçāo deve passar por um teste piloto, visto que cla raramente funciona como planejado.

Refinar a Soluçāo Uma vez testada. a solução deve ser modificada para refletir o conhecimento e as lições obtidas com o teste. Podem ser necessảrias diversas iterações entre o processo de refinamento e o teste da solução, até que se alcance uma soluçāo satisfatória. No entanto, deve-se ter cuidado para nāo se atrasar a implementação dá soluçăo, em busca de uma que scja perfeita.

Implementar a Solução Depois de testada c refinada, a soluçāo cstá pronta para ser implementada na organização. Várias abordagens podem ser utilizadas para esta im plementaçào, incluindo a abordagem top-down e a just-in-lime. No entanto, deve-so considerar que nenhuma delas c universalmente melhor. I)eve-se analisar a natureza da melhoria e das condiçōes da organizaçāo c, baseando-se nesta análisc, escolher a abordagem de implementação a ser utilizada.

\subsubsection{Fase de Lições}

A fase de Liçoes complementa o ciclo de melhoria. Por ser a melhoria continua da capacidade de implementação de mudanças uma das metas do modelo IDEAI, nesta fase toda a experiência adquirida nas fases anteriores ć revista a lim de se determinar o que foi alcançado. quais esforços atingiram suas metas e como a organizaço pode implementar melhorias mais eficientemente no futuro. Devido a esta fasc. as informaçōes de todo o ciclo do modelo IDEAL devem ser armazenadas.

Esta fase c composta pelas seguintes atividades (Gremba \& Mycrs 1997):

Analisar e Validar Nesta atividade, as liçoes são coletadas, analisadas, resumidas e documentadas. Além disso, as necessidades de negócio estabelecidas inicialmente são revistas, a fin de se verificar se foram atingidas, e algumas questōes devem ser respondidas, tais como:

- 1)e que mancira os esforços cumpriram o propósito esperado?

- O que funcionou bem?

- O que pode ser feito mais efetivamente ou elicientemente?

Propor Ações Futuras Nesta atividade são desenvolvidas e documentadas recomendaçoes baseadas na análise da atividade anterior. Propostas para melhorar a implementaçāo de futuras mudanças sāo lornecidas dos patrocinadores. 


\subsection{Considerações Finais}

Neste capitulo foi descrito o modelo IDEAL, cujo objetivo é fornecer uma abordagen sistemática para as atividades de adoçāo de melhorias, sejam elas ferramentas, mètodos ou processos de Engenharia de Softuare auxiliando e coordenando todas as etapas de implantação das mudanças.

A cssência do modelo IDEAL, ou seja, a melhoria continua e gradativa do processo. está incorporada na estratégia para implantaçāo do reúso no processo de descnvolvinento do sofiuare proposta neste trabalho.

Além disso, também estāo incorporados nessá estrategia fatores relacionados aos processos e atividades básicas que compōem o ciclo de vida do software descritos na norma NBR ISO/IEC 12207 que, por sua vez, é apresentada no capítulo a seguir. 


\section{Capítulo 4}

\section{A Norma NBR ISO/IEC 12207 - Processos de Ciclo de Vida de Software}

\subsection{Considerações Iniciais}

A estratégia proposta neste trabalho para a implantacão do reuso no processo de desenvolvimento de software procura incorporar as melhores práticas adotadas pela comunidade de softuare

Neste sentido, a norma NBR ISO/IEC 12207. considerada um modelo de referéncia para capacilação de processos. é o tema abordado neste capítulo.

\subsection{A Norma NBR ISO/IEC 12207}

A NBR ISO/IEC 12207 e uma norma internacional utilizada por muitas organizaçôes para alcançar um diferencial competitivo. Ela define um framework para os processos do ciclo de vida, processos estes aplicados nas atividades de aquisição, fornecimento, desenvolvimento, operação c manutenção de produtos de software.

Esta norma agrupa os processos do ciclo de vida em tres classes, representativas de sua natureza, ilustradas na Figura 4.1 e detalhadas a seguir:

Processos Fundamentais Os processos fundamentais referem-se às atividades essenciais do ciclo de vida do softucare, ou seja. as atividades de aquisicâo. desenvolvimento. operação c manutenção do sofluare. Entre os processos fundamentais estão:

Processo de Aquisição: define as atividades do adquirente forganização que adquire um sistcma, produto ou serviço de software), entre as quais estāo as atividades 


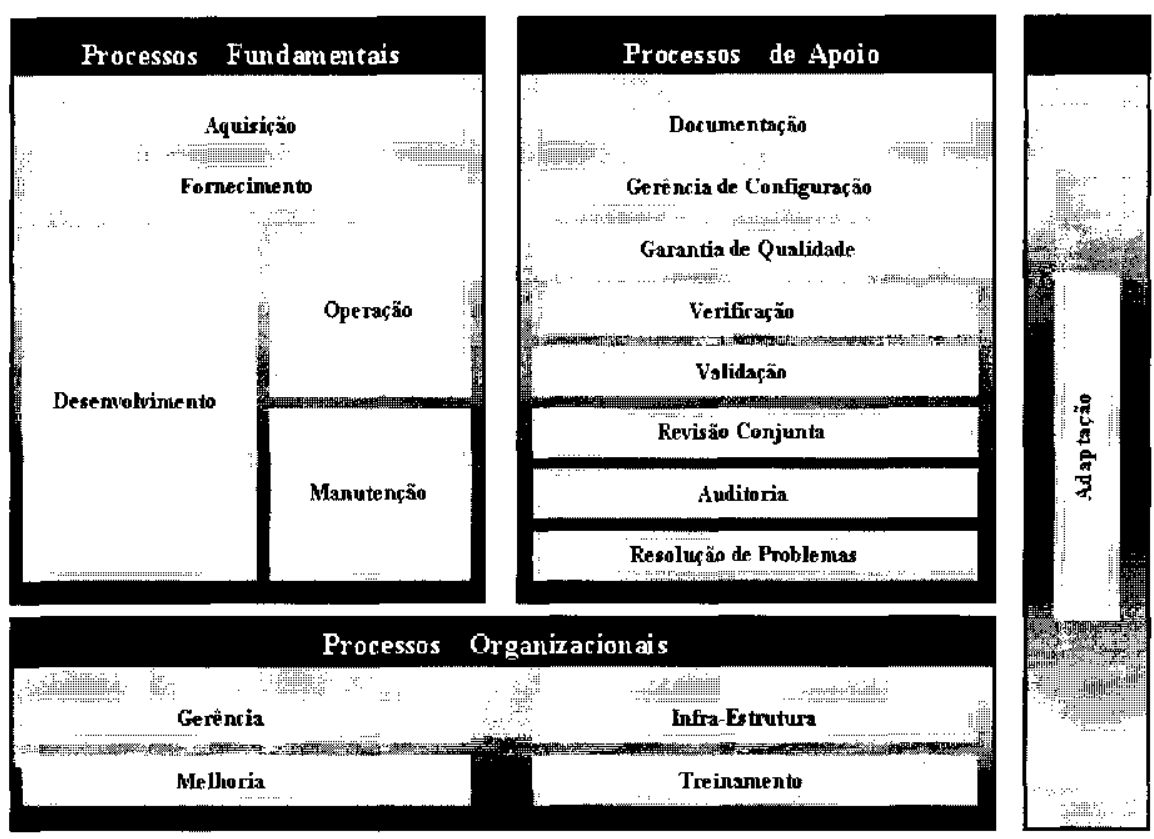

Figura 4.1: Processo do Ciclo de Vida do Software (da Rocha, Maldonado, \& Weber 2001) de preparação c cmissão de um pedido de proposta, a seleção de um fornecedor e a gerência do processo de aceitação do que foi contratado.

Processo de Fornecimento: define as atividades do fornecedor (organização que for nece o produto ao adquirente), entre as quais estāo a confecção de uma proposta para responder ao pedido do adquirente, a assinatura do contrato de desenvolvi mento e a determinação dos procedimentos c rccursos necessários para o desenvolvimento contratado. além da gerência do mesmo.

Processo de Desenvolvimento: define as atividades do desenvolvedor (organização que define e desenvolve o produto de software), entre as quais estão a análise de requisitos, projeto, codificação, teste e a instalaçào dos produtos de software.

Processo de Operação: define as atividades do operador (organização que provê o serviço de operação do sistema computacional), entrc as quais estão operação do produto de software e o suporte operacional aos seus usuários.

Processo de Manutenção: define as atividades do mantenedor (organizaçāo que provê os serviços de manutençāo do sofftware. cntre as quais estào modificaçōes no código (e na sua respectiva documentaçāo) devido à problemas, à necessidade de melhoria ou à adaptação do software, depois de cntregue ao adquirente.

Processos de Apoio São processos que auxiliam c contribuem para o sucesso e qualidade do projeto de software. Os processos desta classe sāo: 
Processo de Documentação: define as atividades para registrar as informaçoes produzidas por um processo ou atjvidade do ciclo de vida. Entre estas atividades estāo o planejamento, projeto, desenvolvimento, produção, edição, distribuição $\mathrm{c}$ manutençăo dos documentos necessários a lodos os intercssados (como gerentes. engenheiros e usuários do sistema ou produto de softuare).

Processo de Gerência de Configuração: define atividades para aplicação de proce dimentos administrativos e técnicos. por todo o ciclo de vida de software. des tinados a identificar e definir os itens de software em um sistema e estabelecer suas linhas básicas (baseline), controlar as modificaçōes e liberações dos itens. registrar e apresentar a situação dos itens e dos pedidos de nodificação, garantir a completeza. a consisténcia e a correçào dos iterns e controlar o armazenamento. a manipulaçào e a distribuiçào dos itens de softuvare.

Processo de Garantia de gualidade: define atividades que garantam a qualidade de processos e produtos de software. ou seja. garantam que estes estāo en confor midade com seus requisitos e com os planos estabelecidos.

Processo de Verificação: define atividades para verificaçào dos produtos de softuare ou seja, atividades para determinar se us produtos de softuare atendem completamente os requisitos e padröes para tele estabelecidos.

Processo de Validação: define atividades para validação dos produtos produzidos pelo projeto de sofuware, isto é, atividades para determinar se o produto final (sistema ou softuarel atende aos requisitos funcionais estabelecidos, ou ainda, se o produto realiza a funçāo esperada.

Processo de Revisão Conjunta: define atividades para avaliar a siluaçāo c os produtos de uma atividade de um projeto. As revisōes são feitas tanto no nivel de gerenciamento do projeto quanto no nivel técnico.

Processo de Auditoria: defne atividades para determinar adequaçāo aos requisitos. planos e contrato

Processo de Resolução de Problemas: define atividades para analisar e resolver problemas de qualquer natureza. Seu objetivo é fornecer meios (em tempo adequado e de forma responsável e documentada) para garantir que todos os problemas encontrados sejam analisados e resolvidos, e que tendencias sejam identificadas.

Processos Organizacionais São utilizados para estabelecer e implenentar uma estrutura de processos e pessoal associados a eles em uma organização. 
Os processos desta classe são:

Processo de Gerência: utilizado por quaisquer uma das partes cnvolvidas, o processo de gerência define atividades genéricas para o gerenciamento de produto. de projeto e de tarcfa(s) do(s) processo(s) envolvidos na construção do softuare.

Processo de Infra-estrutura: define as atividades para estabclccimento e manutençāo da infra-estrutura necessária aos processos, incluindo harduare, sofluare. técnicas e padrōes. entre outros.

Processo de Melhoria: define as atividades para que uma organizaçāo possa estabelecer, avaliar. medir, controlar e melhorar o processo de ciclo de vida do softurare. Valc lcmbrar que pode-se chamar de organização o adquirente, o forneccdor. o desenvolvedor, o operador, o mantenedor e o gerente de processo.

Processo de Treinamento: define as atividades para prover e manter um pessoal com boa capacitação. ou seja, conhecimento e qualificação. É importante que o treinamento seja planejado e realizado com antecedência para que o pessoal com a qualificação necessária ao desenvolvimento do projeto esteja disponivel no momento adequado.

Adaptação Define as atividades necessárias para adaptar a norma para sua aplicação na organização ou em projetos. Esta adaptaçāo deve ter como base os fatores que diferenciam as organizaçōes e projetos de outros, como a estratégia de aquisição. modelos de ciclo de vida e cultura organizacional.

A norma $\dot{e}$, portanto, flexivel, permitindo que as escolhas fiquem à criterio dos seus usuários, feitas com base no estado da arte da tecnologia ou $\mathrm{cm}$ suas necessidades particulares.

E. importante ressaltar também que esta norma provê os requisitos para um conjunto compreensivo e integrado de processos dentro de todo o ciclo de vida, no qual cada pro cesso é construido dentro do ciclo do PDCA (Plan-Do-Check-Act) cujo objetivo principal é a melhoria continua e gradativa do processo (da Rocha, Maldonado, \& Weber 2001).

\subsection{Considerações Finais}

Neste capitulo foram descritos diversos processos considerados na norma NBR ISO/IEC 12207 como parte integrante de um ciclo de vida que resulte em produ tos de qualidade. Entre estes processos estão Documentação, Verificação e Gerenciamento 
de Configuração de Softuare, considerados básicos na estratégia de implantação do reủso no processo de desenvolvimento de software proposta neste trabaho.

Desta maneira, no Capitulo 5 serāo apresentadas algumas consideraçóes sobre a documentaçāo de softuare. 


\section{Capítulo 5}

\section{Documentação de Software}

\subsection{Considerações Iniciais}

A existência de uma boa documentaçăo é um fator muito importante para o processo de desenvolvimento de softuare baseado em componentes, visto que cla ć útil durante a avaliaçāo c uso dos componentes.

Por esta razão. neste capitulo sâo apresentadas diversas consideraçōes referentes ao processo de construçāo e disponibilizaçāo de documentaçōes de qualidade.

\subsection{Documentação de Software}

A documentaçāo de software é uma atividade extremamente importante no processo de desenvolvimento cuja finalidade è retratar fielmente a evolução do softuare.

Segundo Blanqui (1997), a "documentação é crítica para o sucesso no desenvolvimento de um softucare complexo. ... Mas. acima de tudo, a documentaçào è necessária durante a manutenção. o reúso, a evolução, ou na melhoria do softuare, já que estas atividades são geralmente executadas por pessoas que não estiveram envolvidas no seu desenvolvimento".

Para Parnas \& Madey (1995), a documentação deve ser tida como pelo menos tão importante quanto o software, "se existe uma boa documentaçio. o produto de software pode ser revisado e substituido com relativa facilidade: sem uma boa documentaçāo. o produto de sofiware tem scu valor questionável a longo prazo".

Uma documentaçāo bem elaborada pode trazer ainda outros beneficios (Phoha 1997; da Rocha, Maldonado, \& Weber 2001; Blanqui 1997):

- Redução do tempo e esforço despendidos na construção do software; 
- Facilidade de localizaçāo das informaçōes e de comprecnsāo das estruturas do software:

- Facilidade e eficiència no uso do software pclos usuários:

- Permite que atividades como avaliaçāo e modificaçāo do softuare possam ser realiza das sem maiores dificuldades;

- permite que outras pessoas. não participantes do processo de construção do softuare? tenham acesso às decisôes dos desenvolvedores, a como o produto foi construido, possam utilizar componentes previamente construídos e descritos na documentaçào. ou simplesmentc aprovcitar a experiência que nela foi retratada.

No cntanto, tradicionalmente, pouca atenção tem sido dedicada a esta atividade, gerando documentos incompletos, imprecisos e até mesmo incorretos. Embora muitos engenheiros reconheçam a importancia de uma documentação bem construída, em muitas organizaçôes a documentaçào é tida como uma tarefa burocrática, desagradável, exigente e que toma muito tempo e cnergia. Estima-sc que 20\% a $30 \%$ do tempo despendido no desenvolvimento de softuare seja utilizado na confecção da documentação (Parnas \& Madey 1995: da Rocha, Maldonado, \& Weber 2001 ). Esta pouca atenção despendida à documentação se torna preocupante visto que (da Rocha, Maldonado, \& Weber 2001: Blanqui 1997: Andexer 1998):

- Documentos mal elaborados, incompletos, inadequados atrapalham a manutenção do software:

- Documentos contendo informaçōes incorretas degradam a utilidade do software;

- Uma documentação de baixa qualidade pode difieultar o aprendizado do sistema:

- Documentos imprecisos e incompletos podem levar os desenvolvedores a fazerem suposiçōes c, possivelmente, introduzirem erros no softuare.

Diante disso, esforços têm sido cmpregados na tentativa de modificar a visão que os descnvolvedores tèm sobre documentação. fazendo, assim, com que cles passem a desenvolver documentos de melhor qualidade. Neste contcxto, organizaçoes como a ISO c a ANSI tèm proposto que o gerenciamento da documentação seja tratado como mais um processo do ciclo de vida - o Processo de Documentação. 


\subsection{Processo de Documentação}

O Processo de Documentação é um processo de engenharia que se preocupa com o planejamento, projeto, produção e manutenção dos documentos produzidos durante o procésso de desenvolvimento do software. Na Figura 5.1 podem ser vistos alguns dos processos estabelecidos pela NBR ISO/IEC 12207 e alguns dos documentos neles envolvidos, cujo tratamento é de responsabilidade do processo de documentação (IJilera, González, Gutiérrez. \& Martinez 1998; da Rocha, Maldonado, \& Weber 2001).

As seguintes fases compōem o processo de documentação de soflware: (1) Implementação do Processo. (2) Projeto e Desenvolvimento, (3) Produção c (4) Manutençāo (da Rocha. Maldonado, \& Weber 2001\}. Tais fases serāo descritas, respectivamente, nas Secöes 5.3.1, $5.3 .2,5.3 .3$ e 5.3 .4 .

\subsubsection{Implementação do Processo}

O objetivo desta fasc é estudar os requisitos dos documentos a serem desenvolvidos. Este estudo deve dar origem a un "Plano de Documentaçăo" contendo os tipos de documentos a serem construidos, a tecnologia a ser utilizada, a seqüéneia de operacōes para produção e distribuicão dos documentos. e a linguagem a ser utilizada para indexaça e referência.

As atividades que compōem esta fase, nesta seqüencia, são: (1) Identificaçāo dos requisitos da documentaçāo, (2) Definiçāo dos documentos e suas relaçoes, (3) Estabelecimento da organizaçăo dos documentos. (4) Elaboração de um plano de produção e distribuicāo. (5) Elaboraçào de um plano de definiçāo da linguagem dos documentos e (6) Estudo de diferentes alternativas tecnologicas.

Na Figuráa 5.1. são apresentados diversos documentos que podem ser identificados na atividade (2) desta fase. Para cada um destes documentos, diversas informaçōes devem ser fornecidas: titulo, propósito, autor, cronograma para versōes intermediárias, entre outras

Vale ressaltar a importância da linguagem a ser usada na documentação, pois ela irá facilitar o trabalho do pessoal envolvido com a produção do software, os quais precisarão. constantemente, consultar os documentos elaborados. Nela devem ser identificados os termos de referência e indexaçāo a fim de facilitar a localização dos documentos a serem consultados ou modificados

Hilera, González. Gutièrez, \& Martinez (1998) também apresentam um processo de do cumentação composto por fases, bastante scmelhante ao apresentado por da Rocha, Mal- 


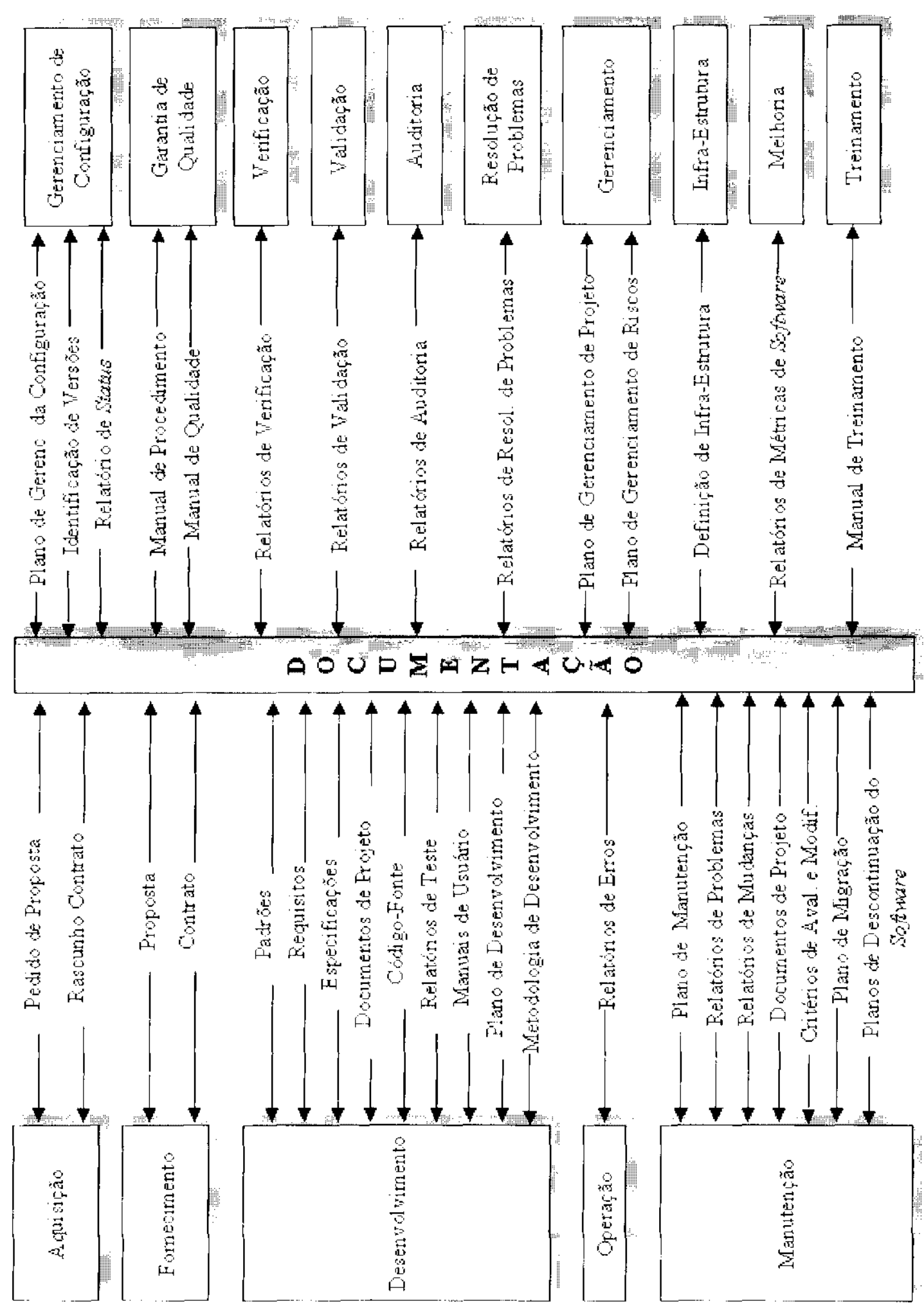

Figura 5.1: O Processo c Alguns Documentos Envolvidos no Ciclo de Vida do Software de Acordo com a NBR ISO/IEC 12207 (da Rocha. Maldonado, \& Weber 2001)

donado, \& Webcr (2001). Segundo o processo cstabelccido por Hilera. González, Gutiérrez. \& Martinez (1998), a atividade de indexaçào ć tida como uma fase do processo, cujo obje- 
tivo é analisar o conteuido dos documentos, identificar os termos de indexaçāo/referència, estabelecer hyperlinks (referência cruzada) c validar os indices produzidos. Ainda neste processo, a scqüencia de fases é: (1) Planejamento da Documentação, (2) Projelo da Documentaçāo, (3) Produção da Documentação. (4) Indexaçāo da Documcntação e (5) Exploração e Manutenção da Documentação.

\subsubsection{Projeto e Desenvolvimento}

Depois de definida a maneira como os documentos serāo construídos, passa-se para a descriçāo dos aspectos exigidos para a produçāo de cada documento, envolvendo desde a sua estrutura interna até a sua apresentação para o usuário final. Todos os documentos devem ser projetados de acordo com os padrōes de documentação, tal como formato, numeraçāo de páginas. localização de tabelas e figuras, entre outros. Alèm disso, todos os documentos devem ser editados e revisados de acorclo com os padrōes citados, scndo sua emissāo dependente da aprovaçāo formal do pessoal responsảvel pela sua revisão.

A seqüència de operaçôes que compōem esta lase é: (1) Projeto da estrutura dos documentos, (2) Projeto do comportamento dinâmico dos documentos, (3) Incorporaçāo dos aspectos de hipermidia ao projeto, (4) Projeto da apresentação dos documentos c (5) Revisão do plano de produção e distribuição dos documentos.

\subsubsection{Produção}

Esta fase tem como objetivo gerar os documentos de acordo com o projeto previamente cstabelecido. Os documentos devem ser construidos contendo as informaçoes geradas no processo de desenvolvimento e seguindo os padrōes definidos na fasc anterior. Além disso. documentos mais importantes devem ser armazenados de acordo com os requisitos de retenção, segurança. manutençào c backup.

Nesta fase, as seguintes atividades devem ser executadas: (1) Preparar o ambiente de produção. (2) Produzir e revisar os documentos. (3) Conceber a identificaçāo dos documentos e (4) Libcrar (publicar) os documentos.

\subsubsection{Manutenção}

Esta fase preocupa-se com as mudanças nos documentos. Mais especificamente, ela trata das tarefas relacionadas à modificaçāo controlada de documentos, à destruiçāo de documentos obsoletos c ao armazcnamento de documeritos em arquivos para que façam partc do "patrimônio documental da organização" (da Rocha, Maldonado, \& Weber 2001). 
As atividades desta fase são: (1) Efetuar a manutenção dos documentos e (2) Armazenar c Eliminar documentos.

Vale lembrar que as alteraçōes cm documentos sob controle de contiguração devem scguir os passos estabelecidos no gerenciamento de configuração

\subsection{Características de uma Documentação Efetiva}

Segundo Andexer (1998), existem algumas caracteristicas que devem estar presentes em uma documentaçāo de qualidade:

Modularidade Sistemas modulares precisam de una documentaçāo tambèm modular:

Precisão e Completude As informacoócs contidas em uma documentacào serào utilizadas ná construçāo e manutenção do software. Quando esta documentaçāo não è precisa ou nāo está completa, os desenvolvedores podem fazer suposiçōes para precncher os detalhes ausentes, podendo, assim, introduzir erros no sistema. Como um outro agravante, tem-sc o fato de que estes erros serão de difîcil deteccão visto que a validaçāo do softuare será feita com base na mesma documentaçāo;

Atualizada Uma documentação desatualizada pode levar os desenvolvedores a não majs utilizarem-na. na melhor das hipóteses, levá-los a cometerem erros, dificultar a comprecnsão do softuare ou ainda aumentar o seu tempo de desenvolvimento, visto que as informaçōes nela contidas nāo correspondem à realidade;

Verificável A documentação deve ser efetivamente verificada/revisada em revisões técni cas lormais:

Padronizada A documentação de um sistema deve ser integradá, formando um conjunto coeso de manuais, nos quais informaçōes relevantes podem ser facilmente acessadas. Uma documentacão padronizada deve ser consistente na sua apresentação e na sua acessibilidade, permitindo uma reduçāo no tempo gasto pelos descnvolvedores para se familiarizarem com diferentes estilos:

Mesmo Conjunto de Documentos Para Cada Passo do Processo Utilizar o mesmo conjunto de documentos para cada passo do processo de desenvolvimento faz com que a documentação seja menor c, atravès do seu uso repetitivo, permite que se encontre mais crros c motiva a remoção destes crros. 


\subsection{Um Padrão Para Documentação}

Scgundo Phoha (1997), a padronizaçāo da documentaçāo pode reduzir o tempo e esforço despendido na construção do softuare, aumentar a sua portabilidade e auxiliar os usuários na sua compreensão.

Nảo existem padrōes universalmente accitos para a documentaçāo de softuare. Porém. cxiste um padrāo para documentação de software cientifico e de engenharia · o ANSI/ANS 10.3 1995 Standard for Documentation of Computer Softuare, cujo objetivo é "encorajar uma melhor comunicaçāo entre o descnvolvedor e o usuário, e facilitar uma selcção. uso, transferência, conversão e modificação efetiva do softucure" (Phoha 1997). Este padrão faz. recomendaçōes quanto ao contcúdo da documentação e sugere a sua separaçào em quatro categorias:

Resumo Contém um resumo dos principais propósitos e capacidades do softuare, provendo informação suficiente para possibilitar uma fácil decisāo de se o softuvare satisfaz. as necessidades do usuário:

Informação da Aplicação Resume o problema que o softuarè se propōe a solucionar e especifica como utilizá-lo. Esta categoria tambèm é responsável por mostrar como recuperar a aplicaçảo quando ela tem problemas, como reiniciá-la e como interagir com ela;

Definição do Problema (Definição Funcional) Esta categoria descreve todos os modelos matemáticos e algoritmos utilizados no programa. Também contém uma descriçāo detalhada de como o problema pode ser resolvido pelo software, incluindo limites de capacidade e processamento de dados;

Informação do Programa Relata a linguagem em que o softuare foi desenvolvido. detalhes rclativos à sua portabilidade, descreve os tipos de dados utilizados, os requisitos de implementação e os comandos de controle para instalação. entre outras informaçōes.

\subsection{Considerações Finais}

Neste capitulo foram apresentados diversos aspectos envolvendo a preparaçāo c disponibilização de uma documentação de software de qualidade.

A documentação é $11 \mathrm{~m}$ dos processos considerados ná norma NBR ISO/IEC 12207 como parte integrante de um ciclo de vida que resulte em produ- 
tos de qualidade e, portanto, ć abordada na estratégia para implantaçāo do reúso proposta neste trabalho.

Un outro processo também considerado na norma é o processo de verificaçāo, incorporado na estratégia anteriormente citada através da realização de revisōes técnicas formais. Estas revisōes, são, portanto, o tema do próximo capitulo. 


\section{Capítulo 6}

\section{Revisão Técnica Formal}

\subsection{Considerações Iniciais}

A qualidade dos componentes é um fator importante para que o rcúso traga benefícios consideráveis para a organização. Desta maneira, é preciso que o processo de desen volvimento possua atividades para analisar se os componentes atendem ans requisitos $\mathrm{c}$ padrões para eles estabelecidos.

Na estratégia para impantação do reúso prosposta neste trabalho. a atividade responsável por esta verificação é a revisão técnica formal, que ć o assunto abordado neste capitulo.

\subsection{Revisões Técnicas Formais}

Durante o ciclo de desenvolvimento de software, diversos artefatos são produzidos: espccificação de requisitos, projeto de dados, código. manual do usuário, entre outros. A fim de garantir que a equipe de desenvolvimento está trabalhando com documentos contendo ao menos a qualidade minima esperada, tais artefatos devem ser alvo de rcvisōes técnicas formais.

As revisōes técnicas formais (RTF) sāo realizadas pelos engenheiros de software e tem como objetivo. segundo Pressman (1997):

- Descobrir erros de funçāo, lógica ou implementação em qualquer representação do software;

- Verificar se o software sob revisão cstá de acordo com os requisitos para cle préestabelecidos - Validação: 
- Garantir que o softuare cstá scndo construído de uma maneira uniforme c de acordo com os padrões da organizaçāo - Verificação;

- Fazer com que os projetos sejam mais gerenciáveis

Além disso, como geralmente são cxccutadas por um grupo de pessoas, as revisões representam um mcio útil de compartilhamento de informacōes e técnicas relacionadas a vários aspectos do software, podendo ser, até mesmo, um espaço de treinamento para os engenheiros juniores (da Rocha, Maldonado, \& Weber 2001). As revisōes permitem ainda que se mantcnha um backup do projeto e promovem a sua continuidade, visto que diversas pessoas se familiarizam com o software, e possibilitam a remoção de defeitos antes do final do ciclo de vida, o que normalmente tem um custo menor (Pressman 1997). Na Tabela 6.1 é apresentada a diferença entre os custos de cada fase do desenvolvimento de software realizado com e sem a exccuçāo de revisōes técnicas formais. Entretanto, por terem a sua execução dependente do esforço humano, tal atividade pode ser afetada por questōes nāo-técnicas, tais como rcvisores com diferentes niveis de especialização, desmotivaçāo, subjetividade do termo "importante" e cnvolvimento de questōes politicas ou pessoais (da Rocha, Maldonado. \& Weber 2001).

Vale lembrar que antes de se realizar as avaliaçōes é necessário que se estabeleça quais sāo os requisitos de qualidade que devem estar presentes nos produtos de softuare e nas alividades que os constroem, e como eles serāo medidos. Existcm diversos modelos de qualidade que auxiliam cstas atividades. Entre eles pode-se citar o Modelo de MCCALL e o Modelo da HEWLE'IY-PACKARD, cujas descriçōes podem ser encontradas em (Pressman 1994). Porém. é valido ressaltar que os requisitos de qualidade e sua maneira de medição nāo precisam. e não devem, ser necessariamente os mesmos descritos nos modelos existentes na literatura. É preciso que cada organização avalie as suas necessidades c possibilidades a fim de definir quais requisitos serão exigidos c como cles serão medidos.

\subsection{A Reunião de Revisão}

As revisōes são conduzidas cm reuniões planejadas e controladas. cnvolvendo de três a cinco participantes e durando. no máximo, duas horas. Além dissso, cada reuniāo deve focar apenas uma pequena parte do software. tendo assim uma maior probabilidade de encontrar erros (Pressman 1994).

Tipicamente, o descnvolvedor de um produto, assim que o termina, solicita a sua revisão ao lider do projeto. Este. por sua vez, passa o produto a um lider de revisão, responsável 


\begin{tabular}{|c|c|c|c|}
\hline Erros Encontrados & Número & Custo da Unidade & Total \\
\hline \multicolumn{4}{|c|}{ Desenvolvimento Com Revisão } \\
\hline Durante o Projeto & 22 & 1.5 & 33 \\
\hline Antes do Teste & 36 & 6.5 & 234 \\
\hline Durante o Teste & 15 & 15 & 315 \\
\hline Depois da Liberaçao & 3 & 67 & $\frac{201}{7}$ \\
\hline
\end{tabular}

Desenvolvimento Sem Revisão

\begin{tabular}{llrr} 
Antes do Teste & 22 & 6.5 & 143 \\
Durante o Teste & 82 & 15 & 1230 \\
Depois da liberaçao & 12 & 67 & 804 \\
\hline
\end{tabular}

Tabela 6.1: Comparação de Custo de Desenvolvimento (Pressman 1997)

por avaliá-10. estabelecer uma agenda para a reuniào, marcar a reuniâo, produzir cópias do produto e distribui-las aos demais revisores para que estes possam analisá-lo previamente e se preparar para a reunião (espera-se que esta preparaçāo leve entre uma e duas horas). Devem participar da revisão o seu lider, o desenvolver do produto avaliado e alguns outros revisores.

$\Lambda$ reuniāo deve começar com uma breve discussão da agenda e uma introdução do produto a ser avaliado. Um dos revisores deve possuir a responsabilidade de anotar todas as questōes importantes discutidas. Depois da introducão do produto deve-se explicar o material apresentado e levantar os problemas encontrados pelos revisores durante sua preparaçāo. Todos os problemas que foren validados devem ser anotados. No final da reunião o produto pode ser aceito sem modificaçăo, rejeitado por possuir erros graves ou accito provisoriamente. Este processo esta ilustrado na Figura 6. I.

\subsection{Diretrizes para Realização da Reunião}

Existem algumas diretrizes que guiam a execução de uma revisāo. Tais diretrizes devem ser previamente estabelecidas, todos os revisores devem ter conhecimento de sua existencia e concordar com o que por elas for definido. A seguir, estão listadas algumas destas diretrizes (Pressman 1997):

1. Revisar o produto e não o produtor.

Uma revisão deverá apontar problemas em um produto, podendo, portanto, causar algum desconforto em seu desenvolvedor. Assim. recomenda-se que os problemas 


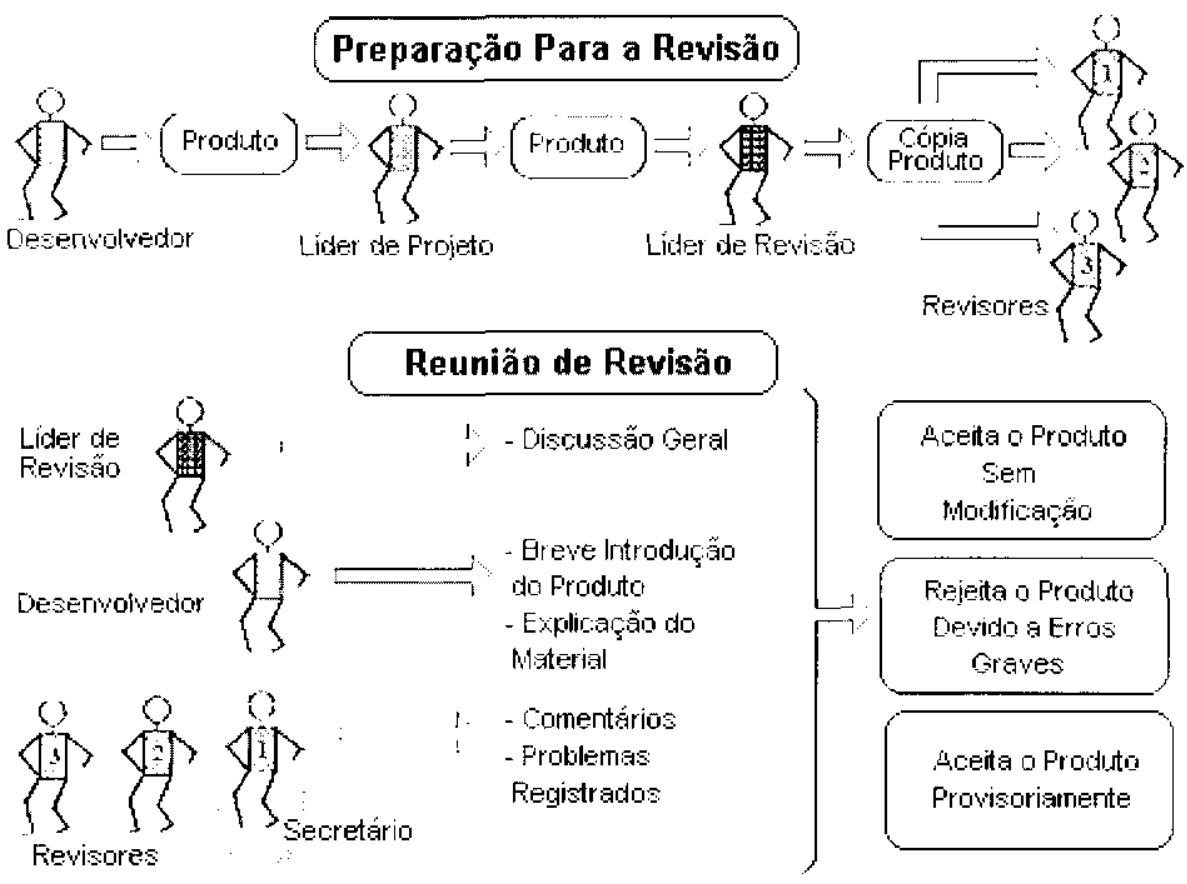

Figura 6.1: Reuniāo de Revisão de Software

scjam apontados de maneira gentil, construtiva, sendo responsabilidade do lider da revisão conduzi-la de maneira a manter o tom e atitude apropriados.

2. Fixar e manter uma agenda.

O lídcr da revisão é responsável por manter o cronograma estabelecido para a reunião, "chamando a atenção" das pessoas quando necessário.

3. Limitar o debate e a refutaçāo.

Quando nāo houver consenso sobre determinada questão, ela deve ser anotada para uma futura discussào (off-line), não permitindo que o assunto se prolongue e comprometa o andamento da reuniāo.

4. Enunciar as áreas problemáticas, mas nāo tentar resolvê-las.

O objctivo da revisāo ć apenas cncontrar os problcmas presentes nos produto. Cabe ao desenvolvedor, com ou sem ajuda de outros. solucioná-los apos o término da reuniāo.

5. Fazer anotaçócs por escrito.

$\hat{E}$ recomendado que o revisor responsável pelas anotações as faça de mancira que seus colegas tenham acesso a elas (em um quadro negro. por exemplo). 
6. Limitar o nümero de participantes e insistir en uma preparaçāo antecipada.

A participação de mais de uma pessoa na revisão certamente resultaráa em uma revisào mais completa do que uma realizada individualmente. Porém. o excesso de participantes pode tumultuar a reuniāo e, desta maneira, prejudicá-la. Deve-se manter o numero de participantes no minimo necessário e solicitar deles comentarios a respeito do produto a ser revisto a fim de obter uma indicaçào de que o participante se preparou para a reuniāo.

7. Desenvolver um checklist para cada produto a ser avaliado.

Esta lista de conferencia irá facilitar a condução da reuniāo c irá permilir que os revisores estejam atentos às questōes mais relcvantes.

8. Alocar os recursos necessários e estabelecer um cronograma para as reuniōes

Para que as revisōes sejam eficientes, elas devem estar estruturadas como tarefas do processo de desenvolvimento e devem, porlanto, ter um tempo reservado, considerando sempre a possibilidade de ocorrerem modificaçōes em funçāo dos scus resultados.

9. Realizar um (reinamento significativo com os revisores.

$\dot{\mathrm{E}}$ importante que os revisores tenham um treinamento formal que aborde questoes relativas ao processo e ao lado psicológico das reuniôes.

10. Rever suas antigas revisōes.

Esta atividade permitirá que se descubra problemas no processo de revisão.

\subsection{Considerações Finais}

Neste capitulo foram apresentados os objetivos das revisōes técnicas formais. além do algumas diretrizes para sua exccução.

As revisöes sāo muito importantes no contexto da estrategia para implantação do reíso proposta neste trabahho visto que elas sāo responsáveis pela veriticaçāo dos componentes. Vale ressallar que a verificação e um dos processos considerados na norma NBR ISO/IEC 12207 como parte integrante de um ciclo de vida que resulte em produtos de qualidade.

Essa norma possui ainda um outro processo que também foi considerado na estratçgia cilada e que è o tema do próximo capítulo - a gerência de configuraçào de softuare. 


\section{Capítulo 7}

\section{Gerenciamento da Configuração de Software}

\subsection{Considerações Iniciais}

Durante o desenvolvimento de componentes de softuare. muitas informaçöes säo produzidas e armazenadas em diversos documentos. Com o progresso na construcão dos componentes, ou mesmo com o sèı reúso, mudanças nestes documentos sāo incvitávcis. Quando estas mudanças nāo sāo analisadas previamente, registradas e reportadas aos que precisam conhecè-las, o processo de construçāo do software pode-se tornar caótico.

Assim, o gerenciamento de configuração de softuare (software configuration management - scm), cujo objetivo principal è o controle das alteraçôes e das versōes dos documcntos, ć também um processo considerado na estratégia para implantação do reúso proposta neste trabalho e. portanto. è descrito neste capitulo.

\subsection{Gerenciamento de Configuração de Soffware}

Segundo Pressman (1997), o "gerenciamento de configuração de software é uma atividadc "guarda-chuva" aplicada durante o processo de software. Devido às mudanças que podem ocorrer a qualquer momento, as atividades de SCM sāo desenvolvidas para (1) identificar alteracōes, (2) controlar as altcraçōes, (3) garantir que as alteraçōes cstāo sendo implementadas apropriadamentc. e (4) reportar as altcraçōes aos que possam ter algum interesse. ... SCM pode ser visto como uma atividade de garantia de qualidade de software que è aplicada por todo o processo de software". 
Durante o processo de construção do sofiware, como jả foi citado, o volume de informaçōes produzidas é realmente alto. tornando inviảvel a manutenção de toda a documentaçāo sob gerenciamento. Assim, alguns documentos, considerados mais importantes, devem ser selecionados e passar a scr chamados de itens da configuração de softuvare, sendo a coleção de todos os itens sclccionados a chamada configuração de software. Vale lembrar que os itcns da configuraçāo podem ser um produto de softuare (programas, procedimentos, manual do usuário, entre outros) ou um produto do desenvolvimento do softuare (descrição de processos, cronogramas, planos, por exemplo). Na Fiğura 7.1 e ilustrada a produçāo de informaçōes pelo processo de desenvolvimento e a seleçāo de algumas destas informaçōes para terem suas alteraçōes controladas pelo Gerenciamento de Configuraçào de Software.

Como o processo de construcāo de softuare é bastante dinâmico, é preciso que cxista um processo de controle de alterações que não prejudique o fluxo de trabalho, nāo burocratizando a realizaçāo de mudanças justificãveis. Para este propósito surgiram as baselines. ou linhas de referência, que sào pontos bem definidos no ciclo de desenvolvimento nos quais os itens sob gerenciamento scrāo identificados, analisados, corrigidos, aprovados e armazenados em um repositório sob controle de acesso (da Rocha, Maldonado. \& Weber 2001). Estas linhas de referência podem ocorrer ao final de cada fase do ciclo de desenvolvimento, ou em outros momentos definidos pela gerência. Após a passagem de um item da configuração por uma linha de referència, ele é considerado "baselined". Os itens "baselined" somente poderão ser alterados mediante aprovação formal de uma solicitação de mudança feilà ao gerente de configuração, evitando assim inconsistências no repositório.

Para se trabalhar com itens sob gerenciamento de configuraçāo é utilizado o método check-in/check-out, ou conferência na entrada/confcrência na saida. Quando for necessária a alteraçāo de um item da configuração, após a aprovação da sua solicitação de mudança, uma cópia do item scrá colocada na área de trabalho do desenvolvedor, na qual ele tem total liberdade de trabalho (check-oul). A partir de entāo, nenhum outro desenvol. vedor serả autorizado a realizar alteraçōes no mesmo ilem. Após o término das alteraçōes. o item sofrerá uma nova revisào e, se aprovado, o item será recolocado no repositório (check-in) e uma nova configuraçāo será formada c congclada no mesmo. A partir deste momento, o item estará liberado para outras alteraçōes (da Rocha, Maldonado, \& Weber 2001). Na Figura 7.2 ć ilustrado o processo de alteraçāo de um item sob Gerenciamento de Configuração de software. 


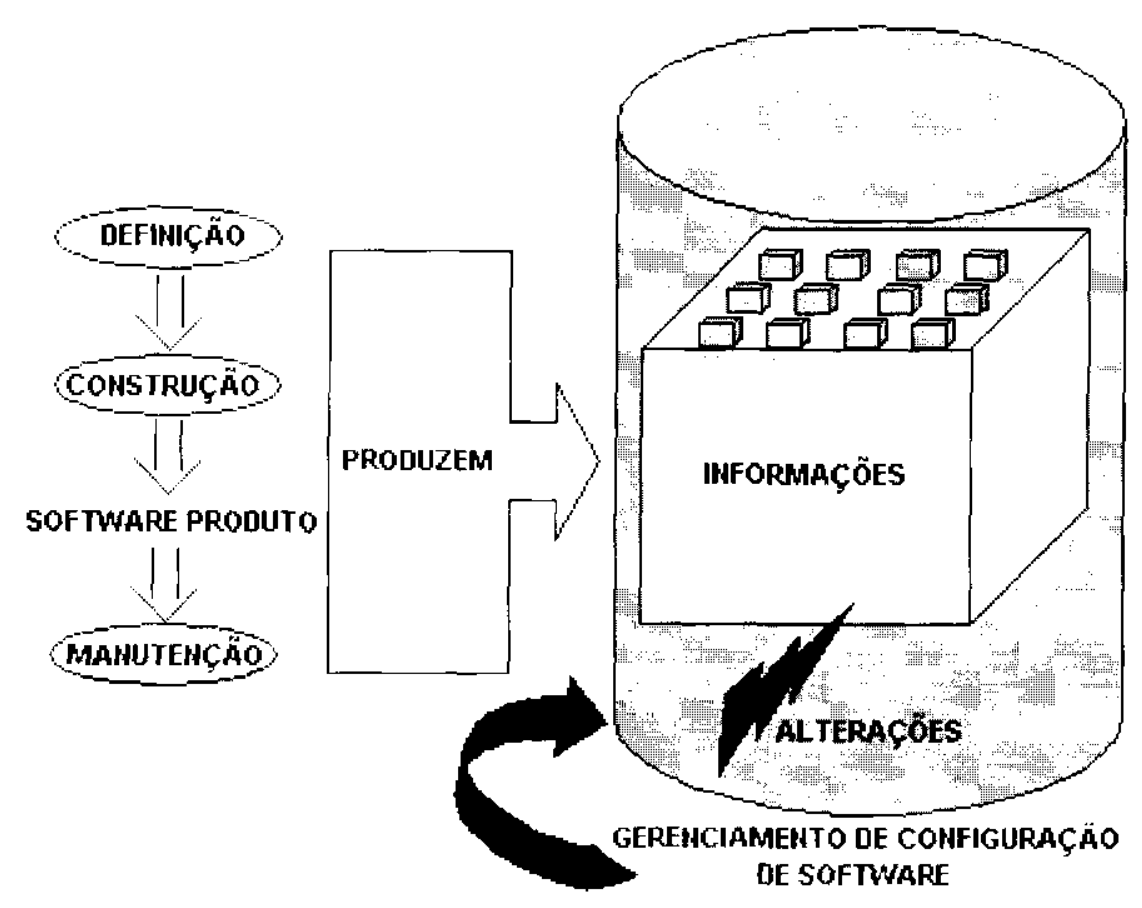

Figura 7.1: Gerenciamento de Configuração de Software

\subsection{Atividades do Gerenciamento de Configuração}

O processo de gerenciamento de configuracão possui diversas atividades, as quais serāo descritas a seguir, segundo apresentado por da Rocha, Maldonado, \& Weber (200l), Pressman (1997), Pacheco (1997) e Berlack (1992).

\subsubsection{Implementação do Processo}

As atividades de implementaçāo e administração da configuração de softuare deverão ser documentadas $\mathrm{cm}$ um plano de gerência de configuraçāo. Neste plano também devem aparecer informaçóes relativas a como, quando e quem executará as atividades de controle da configuraçāo e quais serão os recursos necessários para sua execução.

$\dot{E}$ recomendado que o plano de gerencia de configuração seja descnvolvido de acordo com as particularidades de cada organização, levando em consideraçào seus objetivos, metas, cstratégias e alternativas. No entanto, existem diversos modelos de plano de gerência de configuraçāo (IEEE Standard for Configuration Management Plans, NASA Software Con. figuration Management Plan Item Description, entre outros) que podem ser estudados a fim de que se tome como base aquele que mais se adequar as características particulares da organizaçāo. 


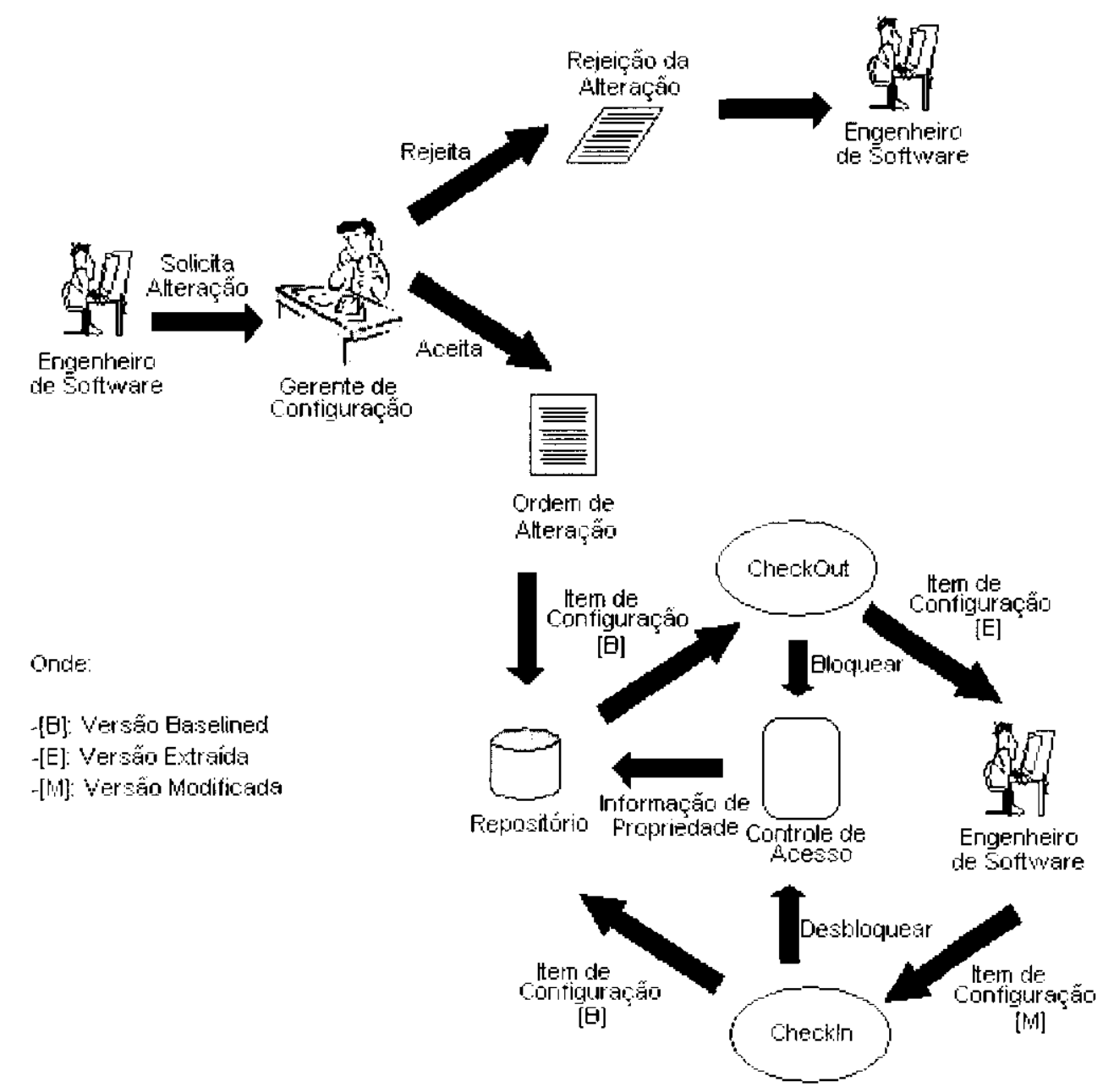

Figura 7.2: Check-In/Check-Out

\subsubsection{Identificação da Configuração}

Após a definição de como se dará a implementação do processo de gerência de configu racão é preciso que se identifique quais serão os itens que irão ser gerenciados, ou seja deve-se realizar a identificaçào da comfiguração.

Nesta atividade deve-se. em primeiro lugar. sclecionar os documentos a serem colocados sob gerĉncia. Vale lembrar que esta escolha deve ser realizada de maneira a restringir o volume de informações a ser gerenciado. evitando assim uma super-documentação que onere o processo de gerência e burocratize demais o processo de desenvolvimento de softuare. Normalmentc. sāo sclecionados os itens mais usados no ciclo de vida, os mais genéricos. os projetados para reúso. os alterados por mais de um desenvolvedor e os de maior im portància para a segurança do sistema (Berlack 1992). Pressman (1997) recomenda que os documentos de especificação do sistema, plano de projeto de sofluware, especificação de 
projeto. programa executável. cntre muitos outros, laçam parte da configuração de sofiware '.

Depois de selecionados os itens que comporào a conliguraçào de sofutare, deve-se iden tificar as relacóes existentes entre eles. facilitando assim a kocalizaçao dos itens afetados por uma alıeraçào. Para esta tarefa. consideram-se cinco classess de relacionamento: (1) Equivalência. (2) Dependência. (3) Derivacão. (4) Sucessāo e (5) Variante.

Depois de escolhidos e relacionados, os itens deverāo ser renomeados com base em um esquema de identificaçāo. Este esquema deve atribuir nomes exclusivos aos itens. permitindo que scja possivel identificar a evolução de suas versōes c a hicrarquia presente.

Assim que o esquema de identificaçào estiver estabelecido. deve se planejar as linhas de referència e definir quais itens serão revisados e armazenados em cada uma dclas.

Por fim, deve-se descrever como os itens serão arquivados e recuperados do reposilório.

\subsubsection{Controle da Configuração}

Dois controles bảsicos são realizados no processo de gerência da configuraçá o conl role de mudancas c o controle de versöes.

\section{Controle de Mudanças}

O mecanismo de controle de mudanças deve ser uma combinaçāo de procedimentos humanos e ferramentas aulomatizadas de maneira a assegurar que as alteraçes em um sofluare scjam realizadas de modo controlado e que o seu efeito para todo o sistema possa ser previsto.

Os procedimentos que compōem esta alividade devem permitir que:

- Pedidos de alteração sejam considerados em conjunto:

- Pedidos similares sejam agrupados;

- Pedidos incompativeis entre si ou com outros do sistema sejam identificados:

- Prioridades sejam atribuidas aos pedidos e que cronogramas sejam gerados de acordo com a prioridade estabelecida.

Na Figura 7.3 é apresentado um processo de controle de mudanças para itens que já tenham passado por uma linhà de referencia.

\footnotetext{
'Em (Pressman 1997) pode ser encontrada a lista completa dos documentos reconendados pelo aulor para comporem a configuraça de sofuare.
} 


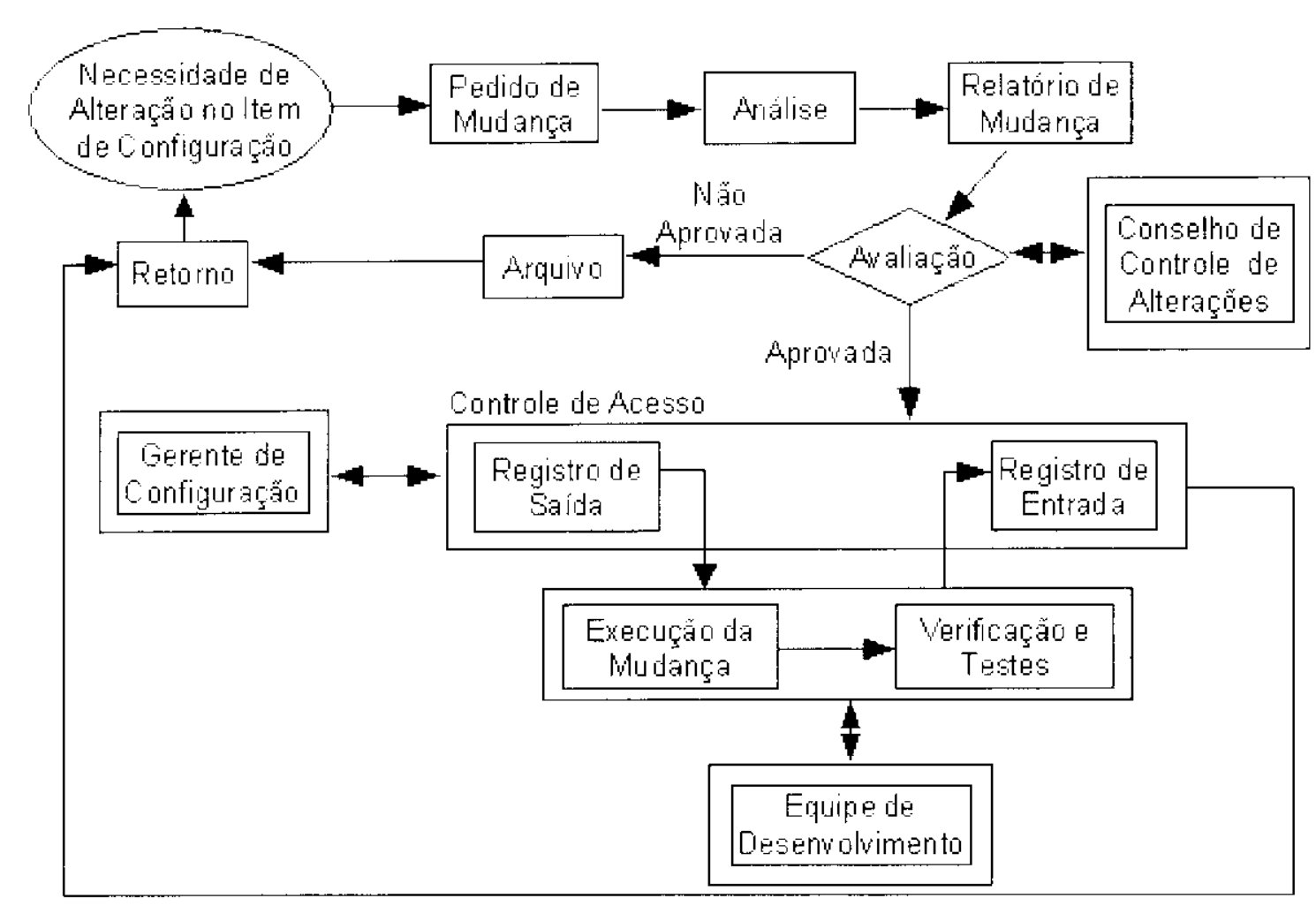

Figura 7.3: Processo de Controle (da Rocha, Maldonado, \& Weber 2001)

\section{Controle de Versões}

Durante o ciclo de desenvolvimento. as informaçoes e produtos evoluem até que atinjam um estado $\mathrm{cm}$ que satisfaçam os requisitos exigidos pelo usuário. Guando estas informacòes e produtos estão sob controle de configuração, ou seja, são itens da configuraçāo, suas altcraçoocs geram novas versōes, todas devidamente armazenadas e identificadas.

$\dot{E}$ conveniente que as versōes sejam identificadas por esquema feito $\mathrm{cm}$ forma de árvore. o qual permite a existência de ramificaçōes a partir de qualquer versào, a manutenção de um histórico das versōes e identificaçào única de cada uma delas.

Dcvido ao grande volume de alteraçōes que podem ser necessárias, o espaço ocupado pelo armazenamento integral de todas as versōes de todos os itens da configuração tornaria inviável a realizaçāo deste controle. Por isso utiliza-se o conceito de delta no armazenamento das versões (cujo objetivo é minimizar o espaço ocupado por elas) (Ambriola, Bendix. \& Ciancarini 1990; da Rocha, Maldonado, \& Weber 2001):

Delta Negativo Armazena-se integralmente a versăo mais rccentc c as diferenças (deltas) existentes até a versão mais antiga: 
Delta Positivo Armazcna-sc a versão mais antiga e as diferenças (deltas) cxistentes até a versāo mais recente.

Para obter versōes anteriores, no caso do delta negativo, processam-se os deltas armazenados desde a versāo mais recente até a desejada. No caso do delta positivo, para montar as versōes mais recentes processam-sc os dellas armazenados desde a versão mais antiga até a desejada. Atualmente, os sistemas de controle de versōes utilizam delta negativo no tronco, visto que è mais comum a utilizacào das versōes mais recentes de cada item. $\mathrm{Na}$ Figura 7.4 é apresentado um exemplo de armazenamento de versōes, sendo utilizado. neste caso, o delta negativo no tronco e o delta positivo nas ramificacões.

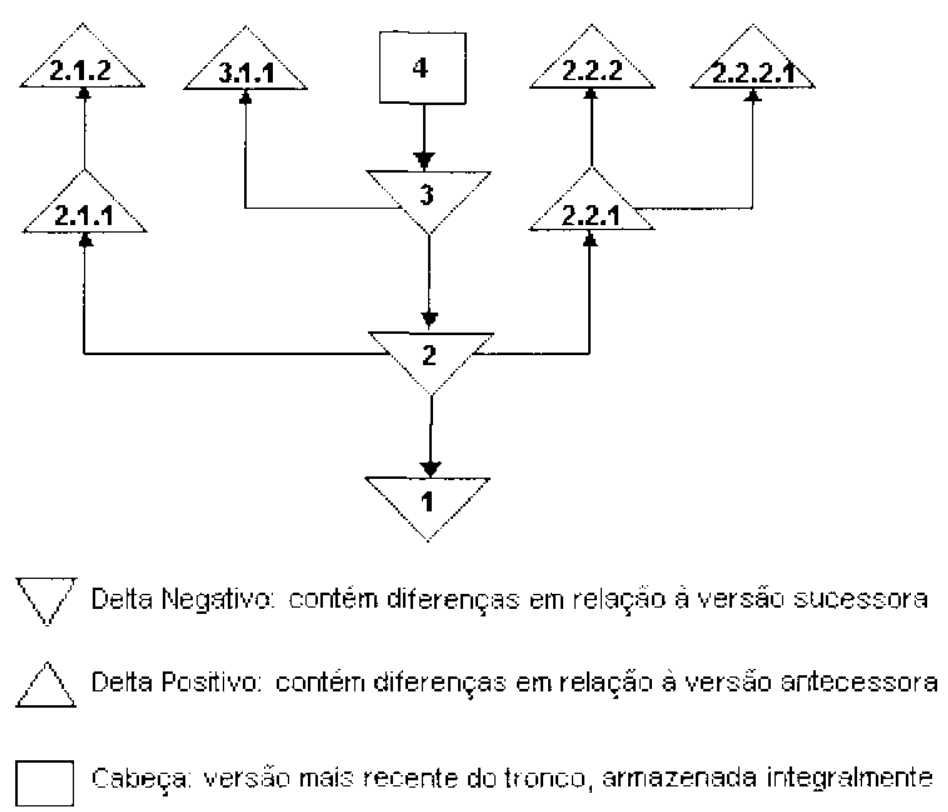

Figura 7.4: Árvore de Versōes de um Documento sob Controle de Versão

O grande volume de versões geradas também torna inviável o controle manual das mesmas. Por isso, normalmente elas são controladas por ferramentas automatizadas. Existem diversas ferramentas de controle de versōes disponiveis no mercado, podendo estas serem proprietárias ou de dominio público. Cada uma delas possui características diferentes quanto à forma de armazcnamento das versōes, quanto ao resultado de diversas operações. quanto à forma de interação com o usuário. Cabe a cada organização cxaminá-las e decidir qual delas melhor se adequa às neccssidades do seu processo de desenvolvimento. Quatro excmplos de ferramentas que realizam o controle de versōes são o Revision Control System (RCS), o Concurrent Versions System (CVS), o WinCVS (interface gráfica para o CVS na plataforma Windows) c o VersionWeb, (cujo objetivo ė o controle de versōes de páginas 
da $w e b)$. todas de domínio público. Mais informaçōes sobre suas características particulares podem ser encontradas, respectivamente, em Yamashiro et al. 1996, Ccderqvist et al. 1992. Harper 2001 e Soares et al. 2001.

\subsubsection{Relato da Situação}

$\dot{\mathrm{E}}$ importante que todas as pessoas envolvidas no desenvolvimento $\mathrm{c}$ manutençāo do software trabalhem com uma documentaçāo atualizada, correspondente à realidade, e que tcnham accsso ao histórico de alterações desta documentaçāo. É preciso que estas pessoas tenham conhecimento de qual foi a alteraçāo cfetuada, quando c quem a exccutou, c quais outros itens foram afetados por ela.

Assim, deve ser mantido um banco de dados contendo todas as ocorrèncias do gerenciamento de configuração acessivel aos desenvolvedores (por meio de senhas, por exemplo). Ademais, relatórios contendo o status do repositório devem ser gerados regularmente e cnviados aos desenvolvedores.

\subsubsection{Avaliação da Configuraçāo}

A identificação e controle das alterações são importantes, mas não são suficientes. Além de se ter conhecimento de quais foram as mudancas sofridas por um item, quando e quem as executou, é preciso garantir a consistência do repositório, ou seja, é preciso que se verifique se a alteração foi implementada corretamente e se os outros itens afetados por esta alteração foram modificados. Esta verificação é realizada atravès de dois tipos de auditoria (ou avaliação) da configuração de softuare, cuja execuçāo ć obrigatória nas linhas de referència:

Auditoria Funcional Esta avaliaçāo preocupa-se com os aspectos internos dos arquivos, tentando identificar omissōes ou erros na configuração que degradem os padrôes estabelecidos para construção do software. É uma espécie de revisào técnica formal (vide Capitulo 6) na configuração do software:

Auditoria Física Esta avaliação é um processo administrativo que complementa a auditoria funcional. Ela preocupa-se em verificar se a configuraçāo a ser congelada na linha de referēncia está composta pela versāo mais recente de seus itens e se os padrōes foram devidamente aplicados. Algumas questōes desta auditoria são:

- As alteraçōes especificadas no Pedido de Alteração foram efetuadas? Alguma modificacão adicional foi incorporada? 
- Foi efetuada a revisão técnica formal?

- Os padrões estabelecidos foram aplicados?

- Os padroes de Engenharia de Softuare foram seguidos?

- A data c o autor da alteraçáo foram especificados? Os atributos dos it ens refletem a alteracūos?

- Todos os itens da configuração relacionados foram atualizados apropriadamente?

\subsubsection{Controle de Interface}

O controle de interface coordena as mudanças nos itens da configuraçāo causadas por alteraçōes em produtos do desenvolvimento que não estejam sendo controlados. Equipamentos. software de suporte, assim como outros projetos devem ser examinados na busca por possiveis interfaces com o projeto sob controle (Pacheco 1997; Bcrlack 1992).

Para cada interface, o plano de gerenciamento da configuraça deve descrever:

1. O tipo de interface:

2. As unidades organizacionais afetadas;

3. Como será feito o controle sobre a interface:

4. Como os documentos de controle da interface serão aprovados.

\subsubsection{Controle de Sub-Contratados e Fornecedores}

O controle de sub-contratados e fornecedores coordena a forma como os itens que foram desenvolvidos por solicitação a outras organizacōes ou foram adquiridos já prontos são testados e incorporados ao repositorio do projeto (Pacheco 1997; Berlack 1992).

Para itens sub-contratados, o plano de gerenciamento da configuração deve descrever:

1. Os requisitos de gerenciamento de configuraçāo de softuare a serem satisfeitos pelo sub-contratado:

2. Como será feito o monitoramento do sub contratado:

3. Como o código, documentaça e dados externos scrão testados. aceitos e adicionados ao projeto:

4. Como serão tratadas as questōes de propricdade do código produzido, como direitos autorais e royalties. 
Para itens adquiridos prontos, o plano de gerenciamento da configuraçāo deve descrever:

1. Como scrão recebidos, testados e colocados sob controle de gerenciamento de configuraçào;

2. Como as mudanças no softuare do fornecedor serão tratadas;

3. Sc c como o fornecedor participará no processo de gerenciamento de mudança do projeto.

Itens da configuraçāo poderāo ser adquiridos de fornecedores, sub-contratados, clientes, outros projetos ou outras fontes.

\subsubsection{Gerência da Liberaçāo e Entrega}

A liberação e entrega do software, assim como sua documentação, devem ser formalmente controladas. Os documentos e códigos relacionados a funçōes criticas c de segurança devem ser muito bem elaborados, empacotados c liberados de acordo com as politicas da organizaçāo.

\subsection{Consideraçōes Finais}

Neste capitulo foi conceituado o gerenciamento de configuração de software, visto a importancia do controle de mudanças e do controle de versōes dos componentes do repositório em um processo de descnvolvimento baseado no reúso de componentes.

No capítulo a seguir, a estratégia para implantação do reüso, resultado principal deste trabalho de mestrado, é apresentada em detalhes. 


\section{Capítulo 8}

\section{Diretrizes para o Processo de Implantação do Reúso}

\subsection{Consideraçōes Iniciais}

O reúso de componentes pode trazer vantagens competitivas consideráveis para uma organização. Porém. sua prática efetiva nāo é uma tarefa trivial, exigindo a exccução de diversas atividades. Neste capitulo, são apresentadas diretrizes para a implantação de um processo com atividades relativamente simples e básicas, introduzidas gradativamente. porem consideradas importantes para a viabilização c implantaçāo efetiva do reúso.

É importante ressaltar que essas diretrizes são fruto dos estudos e análises desenvolvidos tomando como base as caracteristicas do ambiente no qual o estudo de caso lapresentado no Apêndice A) foi rcalizado. No cntanto, como pode-se perceber pela relação aprescntada a seguir, tais caracteristicas sāo comuns em muitas organizaçōes que produzem software, o que viabiliza a utilização das diretrizes propostas por muitos outros ambientes que não um laboratorio de pesquisa.

As principais caracteristicas dos ambientes para os quais estāo voltadas as diretrizes apresentadas neste capítulo sāo:

- Por um lado:

- Interesse no rcuso de seus programas;

- Interesse ná manutenção de um histórico dos trabalhos dos desenvolvedores c no controle das alteraçōes efetuadas em seus programas.

- Por outro lado: 
- Poucos descnvolvedores:

- Falta de recursos ou indisponibilidade dos mesmos para aquisição de ferramentas de sofware proprietảias:

- Inexistência de um organograma formal (gerente, diretor, desenvolvedor);

- Alta rotatividade dos desenvolvedores;

- Utilização de poucas ou nenhuma prática pregada pela comunidade de Engenharia de Softuare no desenvolvimento de software.

\subsection{Os Artefatos e os Tipos de Reúso}

Foram apresentadas no Capitulo 2 (Seção 2.2) diversas definições para o reúso nas quais é ressaltado o fato de poder-se reutilizar diversos tipos de "bens de soflware". Porém. cmbora a reutilização de artefatos como especificaçòes e processos, por excmplo, scja reconhecidamente valiosa, sua execuçāo nāo ć tradicional. Assim, para simplificar e diminuir as alteraçōes necessärias no processo tradicional de desenvolvimento de software das organizaçoes e, conseqüentemente, aumentar a receptividade ao reúso, neste trabalho. propōe-se que uma organização inicie seus esforços para introdução do reúso apenas através do rcúso interno de artefatos do tipo código-fonte. No caso deste trabalho, considera-se código orientado a objeto, sendo um componente composto por uma classe e seus respectivos métodos. Esta característica, no entanto. não impossibilita o uso das diretrizes aqui apresentadas em códigos desenvolvidos em outra técnica, para as quais seriam necessárias, entretanto, algumas adaptaçoes.

As diretrizes para introdução do reúso apresentadas neste trabalho permitem a utiliza(cão dos quatro "tipos de reúso", scgundo a classificação apresentada por Holanda, Souza, \& Melo (2000) e descrita na Seção 2.2: caixa-preta, transparente, caixa-cinza c caixa-branca O reûso caixa-preta é viabilizado devido à grande quantidade de informaçoes referentes à funcionalidade e estrutura do componente, presentes no conteúdo sugcrido para sua documentaçāo, o qual. acredita-se. torna desnecessário o uso do reúso transparente. Este último, por sua vez, pode ser utilizado, caso nccessário, através do estudo do código-fonte, também disponibilizado ao usuário segundo as dirctrizes sugeridas. O reúso caixa-cinza é viabilizado devido à possibilidade de se inserir componentes que exijam parâmetros para configuracão de sua execucão c o reúso caixa-branca é viabilizado por ser permitido que alteraçōes nos componentes scjam realizadas gerando novas versōes, caso as modificaçōes 
nāo alterem sua funcionalidade, ou novos componentes, caso as modificaçōes alterem sua funcionalidade original.

\subsection{Estratégia para Implantação do Reúso}

Como a introdução do reúso nas organizações nāo é uma atividade simples, considerase importante a utilização de uma cstratégia de mclhoria continua através da qual o reúso scja implantado gradualmentc. Neste trabalho, essa estratégia, ilustrada na Figura 8.1, c baseada no modelo IDEAL (apresentado no Capitulo 3).

O modelo apresentado na Figura 8.1 descreve cinco ctapas de um processo de melhoria: inicialização, diagnóstico, estabelecimento, ação e lições. A quantidade de tempo necessária para completar o ciclo depende de cada organização.

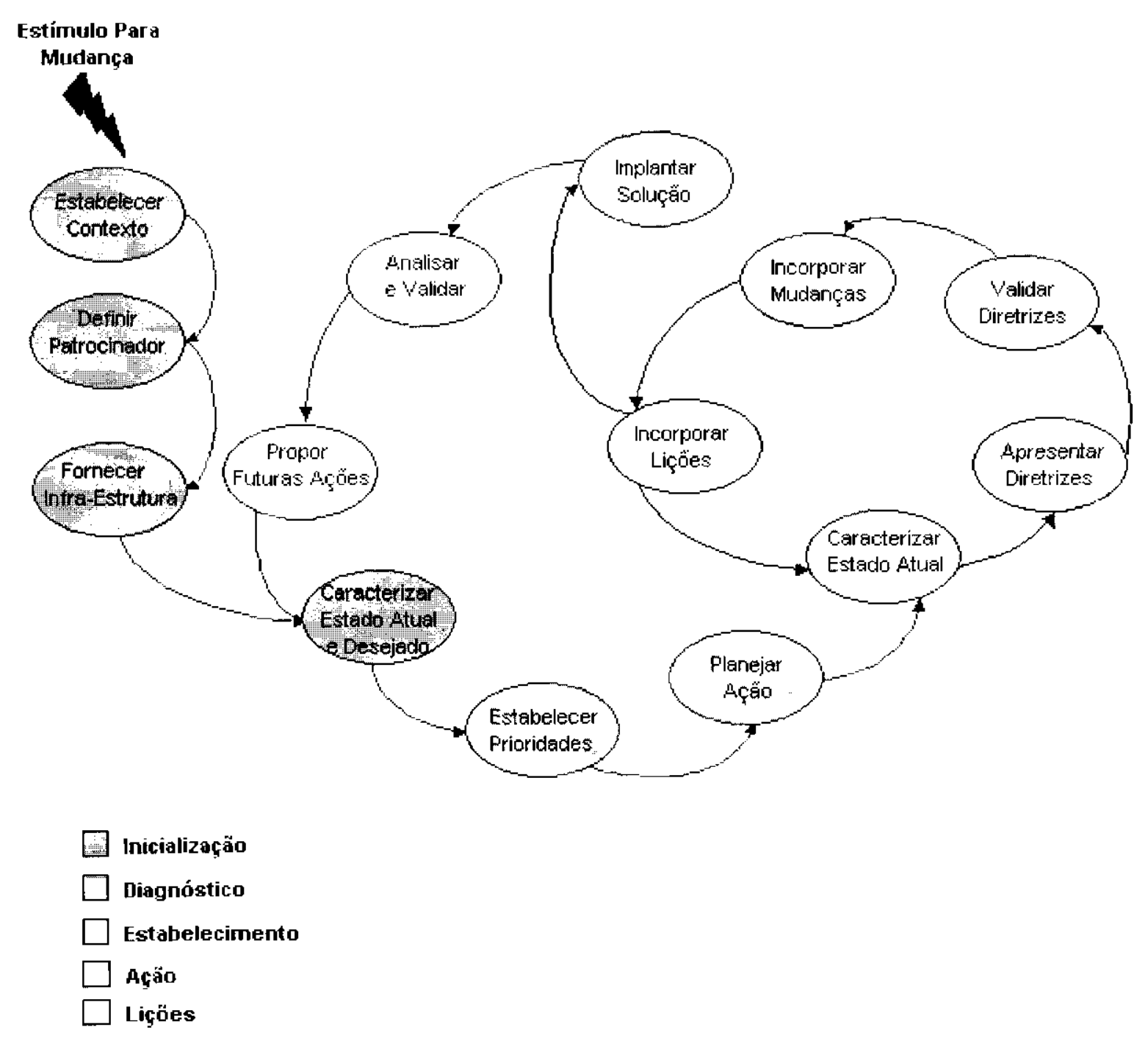

Figura 8.1: Estratégia de Melhoria Continua Utilizada no Processo de Inplantação do Reúso 
Nas Seções 8.3.1, 8.3.2, 8.3.3 e 8.3.4, cada uma destas etapas é detalhada.

\subsubsection{Inicializaçāo}

O primeiro passo para iniciar o processo de introduçāo do reúso é identificar os estímulos para tal iniciativa.

Confirmado o interesse da organizaçāo $\mathrm{em}$ implantar o reúso no seu processo de desenvolvimento, é preciso que se cstabeleça o escopo e o contexto da organização nos quais a iniciativa irá se desenvolver. ou seja, é preciso que se defina quais processos e funçōes serão afetados, como estas alteraçōes irāo incidir sobre outras iniciativas e quais benefícios são esperados.

Conhecido o escopo da organização a ser afetado pelas mudanças, uma estratégia deve ser montada para convencer todos as pessoas envolvidas na melhoria de que as alteraçōes trarāo beneficios.

Como qualquer processo de implantaçāo que exija mudanças, a existência de um patrocinador para as atividades de definição e implantação dos padrōes c processos que forem julgados necessários é de suma importância. Assim, um dos primeiros passos a serem dados em direção a implantação do reúso tal como proposto neste trabalho é conseguir o "apoio gerencial" para esta iniciativa. Este patrocinador terá a função de garantir os recursos necessários para a iniciativa, incentivar sua continuidade, principalmente $\mathrm{cm}$ momentos de dificuldade, e garantir que metas e responsabilidades sejam cumpridas.

Estabclecido o interesse em implantar o reuiso na organização e garantido o comprometimento dos patrocinadores com tal iniciativa, é preciso que se defina sua infra-estrutura, ou seja, é preciso que se estabcleça os papéis e responsabilidades necessários para o de senvolvimento do processo de melhoria. Para o processo de introdução do reúso proposto neste trabalho, tal infra-estrutura é formada por um grupo de trabalho cuja função é conduzir os esforços para definir e implantar as melhorias necessánias. Sugere-se que este grupo seja formado por ao menos uma pessoa da área de Engenharia de Software e uma ou mais pessoas da área de desenvolvimento, com conhecimento na forma de trabalho da equipe e no dominio explorado pela organizaçāo. Os integrantes deste grupo não precisam dedicar-se em tempo integral ao mesmo, porém é preciso que tenham respaldo de seus "chefes" para que dediquem ao projeto uma quantidade de tempo suficiente para nāo com prometer o bom andamento do mesmo. Acredita-se que para o processo aqui proposto, um dia de dedicacão por semana de cada um dos integrantes. exceto o engenheiro de softuare é suficiente para um bom fluxo de trabalho. No caso do engenheiro, a quantidade de tempo 
dedicado ao projeto dependerá muito de sua experiência nos tópicos a serem abordados e da disponibilidade de tempo para a implantação do reúso.

\subsubsection{Diagnóstico e Estabelecimento}

O objetivo da ctapa de Diagnóstico c compreender o estado atual do processo de desenvolvimento e o estado que se deseja alcançar. A partir desta informação, pode-se desenvolver um entendimento maior do trabalho a ser realizado para alcançar a melhoria desejada.

A caracterizaçāo do estado atual é fcila através de uma avaliação do processo de desen volvimento atualmente executado na organizaçāo em relaçāo ao que se deseja como estado futuro (um modelo de referencia). Tal avaliaçāo cnvolve o lcvantamento de informaçoes que. dimensionem a capacidade real do processo c pode ser feita através de rcuniōes, cntrevistas e análise de documentos. Como resultado, obtém-se uma lista de pontos fortes e fracos do processo a partir dos quais as prioridades de melhoria săo estabelecidas.

Neste trabalho, o modelo de referència selecionado te a norma NBR ISO/IEC 12207 (des crita no Capítulo 4), considerando-se as caracteristicas particulares do reúso de componentes.

Para que nāo haja impactos sérios à organizaçāo e rejeiçāo às mudanças, vale ressaltar que nāo se deve implantar todas as altcraçōes de uma só vez. Assim, na etapa de Estabelecimento, o objetivo ė, a partir do resultado das análises da etapa anterior (Diagnóstico). estabelecer uma ordem de prioridade para as alteraçōes c desenvolver um plano que contemple os trabalhos a serem realizados. Inicialmente devem ser introduzidas atividades relativamente simples e básicas, porém consideradas importantes para a viabilizaçào c implantação efetiva do reúso. A partir desta experiència, considerando seus erros, acertos e possibilidades de expansāo, novas atividades devem ser definidas c implantadas.

O cstabelecimento de prioridades deve considerar fatores como dependenncia entrc as atividades, limitação de recursos, prioridades da organizaçào, entre outras.

O plano de ações deve contemplar questōes como cronograma, recursos e responsabilidades, considerando as atividades e prioridades estabelecidas.

Cabe ao engenheiro de software (pertencente ao grupo de trabalho) executar estas atividades. É sugerida a realização de uma primeira reunião do grupo de trabalho para discussão. cm linhas gerais, das alteraçōes que serão necessárias e de um cronograma para realizaçāo das reuniōes que abordarāo cada um dos tópicos de mudança. 
Ncste trabalho, sugere-se que as primeiras atividades a serem implantadas no processo de introduçâo do reúso sejam: requisitos para documentaçâo, execução de verificaçāo nos componentes (realizada atravès de revisões técnicas formais) e gerência de configuraçāo, todas pertencentes à classc dos processos de apoio da norma NBR ISO/IEC 12207 e realçadas na Figura 8.2. Cada uma destas atividades será mclhor explorada nas Seçōes 8.5.1, 8.5.2 e 8.5.3. respectivamente. Adianta-se porém. que a implantação de cada uma delas tambèm è realizada gradualmente (melhoria continua).

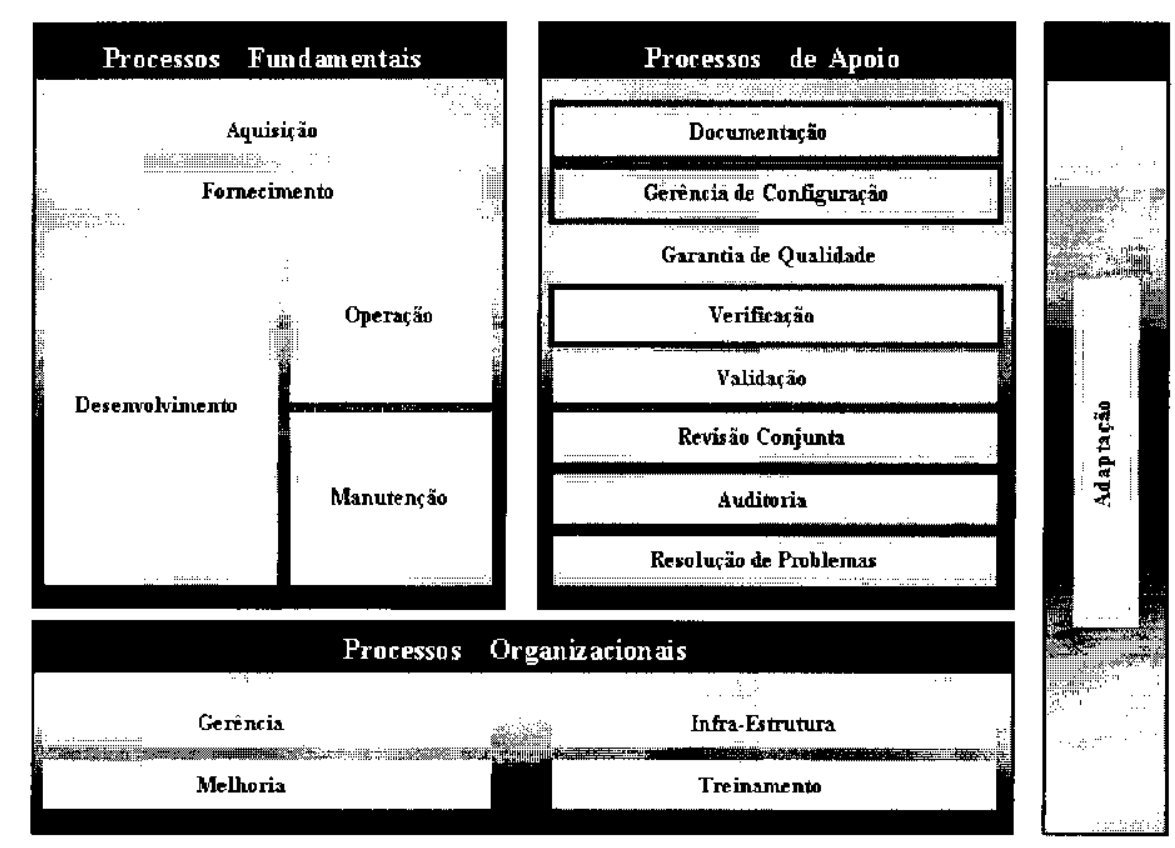

Figura 8.2: NBR ISO/IEC 12207 - Processos Sclccionados

$\hat{E}$ preciso que se esclareça que a decisão de se iniciar o processo de melhoria através da implantaçāo destas atividades resultou de um estudo das necessidades mais latentes no ambiente de estudo de caso. Além disso, é importante ressaltar que cstas atividades, para o caso especifico deste trabalho, nāo podem ser definidas e implantadas aleatoriamente. Ao contrârio, existe uma ordem fruto das dependências existentes entre elas. Assim, devese em primeiro lugar definir os requisitos para documentaçāo, seguido pelo processo de execuçào da verificaçào e os critérios das revisões para, por fim. definir o processo dc gerência da configuraçāo.

\subsubsection{Ação}

Nesta elapa, o plano de acão desenvolvido anteriormente deve ser colocado em prática. Como foi tratado anteriormentc, a receptividade às mudanças necessárias para a introdu- 
çăo do reúso pode nảo ser boa. assim. é importante que cada atividade descrita no plano de ação também seja plancjada c implantada de maneira gradativa.

Assim, a etapa de Açào é composta por cinco fases, sendo quatro delas pertences a um mini-ciclo, ilustrado na Figura 8.3. Em cada "rodada" neste mini-ciclo melhora-se continuamente a forma como as atividades são definidas e implantadas.

1. Diagnóstico: caracteriza-se o estado atual da organizaçāo ná prática da atividade com relação a um modelo inicial de referència. Deve-sc ressaltar que é muito importante que processos e padrōes jà existentes na organização e de qualidade/efetividade com provada scjam mantidos. É necessário, no cntanto. que se tenha cuidado para năo definir padröes/atividades incompativeis entre si;

2. Estabelecimento: apresenta-se diretries para as tarefas e requisitos envolvidos na atividade abordada;

3. Açāo: valida-se as direırizes apresentadas e incorpora-se mudanças nas tarefas $c$ requisitos definidos para a atividade abordada $c$, sc necessário, também na definiçāo das tarefas e requisitos de outras atividades abordadas anteriormente:

4. Licōes: registra-se liçōes sobre a definição da atividade.

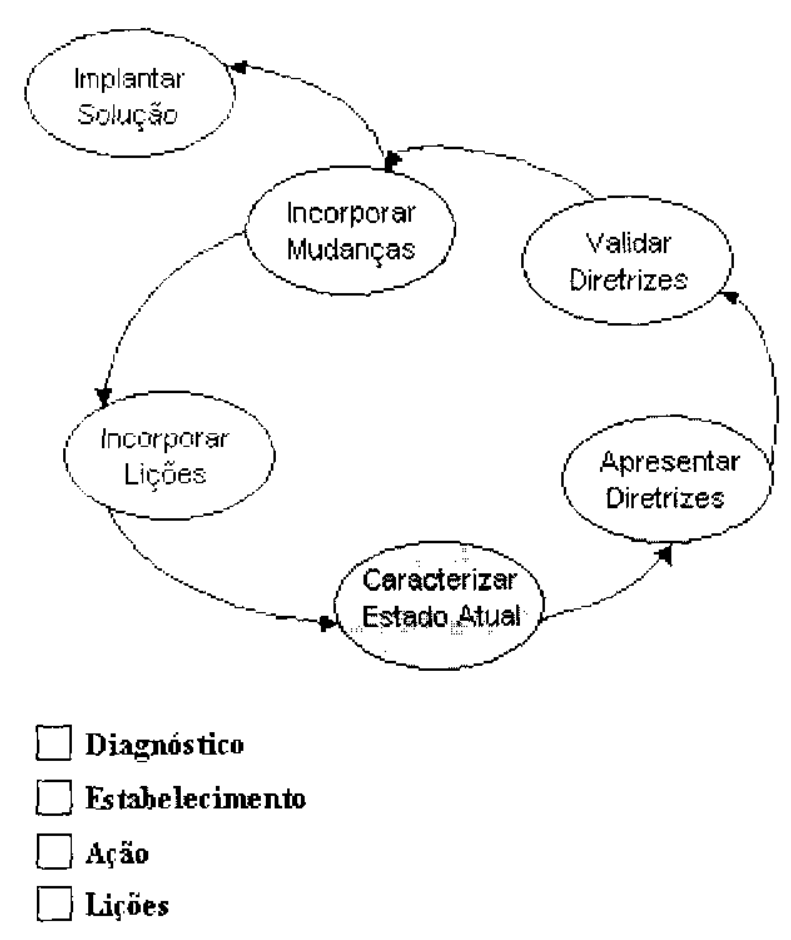

Figura 8.3: Elapas da Fase de Ação 
Após a passagem de lodas as atividades programadas no plano de ação por este miniciclo. a atividade de implantaçāo deve ser realizada, ou seja, deve-se implantar as tarefas e requisitos descritos em todas as atividades, primeiramente $\mathrm{cm}$ um projeto piloto, c posteriormente, por todo o escopo da organização envolvido na introduçāo do reuiso.

A ctapa de Ação é ilustrada na Figura 8.3.

\subsubsection{Lições}

Esta ctapa contempla a idéia de melhoria continua da estratégia de implantação do reúso. Nela, toda a experiçncia adquirida deve ser revisada c utilizada para otimizar a estrategia e identificar as metas que foram cumpridas.

Assim, as informaçōes de todo o ciclo devem ser armazenadas para que, na atividade de análise e validação, as liçōes sejam coletadas, analisadas, resumidas e documentadas. A partir destas informaçōes, devc-se identificar quais objctivos foram cumpridos, identificar como mclhorar a eficiência da estratégia. identificar como as resistências às mudanças podem ser minimizadas, garantir a continuidade do comprometimento dos patrocinadores. entre outras coisas.

Após a atividade de análise c validação, ganham espaço os esforcos para desenvolver e documentar as recomendaçōes para melhoria da esıratęgia.

Desta mancira, em cada "rodada" no ciclo apresentado na Figura 8.1, melhora-se conlinuamente e gradativamente o processo de desenvolvimento de softuvare da organização, através da implantação de novas atividades e de alterações nas já implantadas, e a estraleggia de melhoria, através da incorporaçăo da experiência adquirida.

\subsection{Operacionalizaçāo da Estratégia}

Como foi visto na seção anterior, a estratégia para implantaçāo do reúso envolve uma sćrie de definiçóes e decisōes. Cabc ao engenheiro de softuare (pertencente ao grupo de trabalho) coordenar reuniôes nas quais essas definiçōes c decisōes serão tomadas. Neste trabalho. sugere-se que as reuniöes ocorram da seguinte mancira:

- Atividades Pré-Reuniaao:

- O engenheiro de software do grupo prepara um documento de diretrizes para a atividade a ser abordada na reuniāo e envia-o ao restante do grupo de desenvolvimento com pelo menos alguns dias de antecedência em relaçāo a reunião. O documento de diretrizes tem o objetivo de apresentar as sugestões do enge- 
nheiro de sofinvare para a implantação de $u$ m detcrminado tópico. É importante ressaltar a necessidade de os participantes das reuniōes terem ao menos um conhecimento minimo sobre o assunto a ser tratado nas nesmas. Caso isto nảo aconteça, cabe ao engenheiro de sofuware apresentar no documento de diretrizes uma breve teoria sobre o assunto, ressaltando seus pontos fortes e fracos:

- O restante do grupo estuda o documcrito de diretrizes e prepara suas sugestóes para a reuniāo.

- Atividades da Rcuniāo:

- Durante a reuniāo. o engenheiro de sofiware exerce o papel de mediador da mesma, conduzindo-a de modo que cla atinja seus objetivos;

- O engenhciro realiza uma breve explicacāo do conteúdo proposto no documento de diretrizes e das razóes que o levaram a tal decisão:

- Todos os integrantes do grupo apresentam e analisam os itens que julgaram problcmáticos:

- Em comum acordo, o grupo scleciona os itens que deverão ser alterados;

- O engenheiro anota todas as decisōes.

- Atividades Pós-Reuniāo:

- A partir das decisōes tomadas na reunião. o engenhciro prepara uma ata de reuniāo e um documento de resoluçōes para o assunto abordado, e os envia aos outros participantes da reunião. A ata tem o objetivo de retratar as decisōes tomadas na reuniāo. O documento de resolucooes deve conter as tarefas e requisitos definidos para um determinado tópico, incluindo alteraçōes advindas ou nào de reuniōes. É importante ressaltar que, quando o documento de resoluçōes registrar alteraçōes não definidas $\mathrm{em}$ reunião, faz-se necessário a sua aprovaçāo formal (por escrito) por parte de todos os integrantes do grupo de trabalho.

Cada uma das reuniôes deve durar em torno de duas horas, dependendo do nivel de complexidade do assunto e da quantidade de sugestōes e divergências com relação ao mesmo. Assuntos mais complexos podem ser tratados em mais de uma reunião. Nestes casos, deve-se ter cuidado para dividir os tópicos de maneira coerente. Quanto ao documento de diretrizes, sugere-se que este contenha todo o contcudo a ser abordado, independente do 
nümcro de rcuniōes que serão necessảrias para fazè-lo. Cabe ao engenheiro de softuare avisar ao grupo quais tópicos serào abordados em càda uma das rcuniōes.

Guanto ao cronograma de reuniōes, deve-se salientar que o mesmo deve possuir um intervalo razoável de tempo entre as mesmas (sugere-se que este tempo seja de, ao menos, quinze dias) para que o engenheiro de software tenha tempo hábil para preparar o documento de diretrizes e enviá-lo ao grupo com uma certa antecedência, alćm de permitir ao grupo de trabalho sua leitura com certa tranqüilidade. Este periodo também é utilizado para a execução das atividades da elapa de Liçōes do sub-ciclo apresentado na Figura 8.3.

É importante que o patrocinador do reúso na organização esteja ciente de todas as decisões tomadas e seja conheccdor, se possível, do conteúdo de todos os documentos produzidos.

\subsection{Atividades Sugeridas para o Início do Processo de Introdução do Reúso}

Como já foi citado anteriormente. nào se deve cxccutar todas as mudanças neccssárias para a introduçāo do reúso de uma só vez. Assim, foram sclecionadas algumas atividades relativamente simples e básicas, consideradas, no estudo de caso, importantes para a viabilizaçāo do reūso. São elas: requisitos para documentaçāo, execuçāo de verificação nos componentes (realizada através de revisōes técnicas formais) e gerência de configuraçāo.

Na Figura 8.4, é apresentada a relação entre as atividades sclecionadas e algumas funcionalidades esperadas de um repositório que serăo impactadas pelos requisitos para clas estabelecidos.

E importante lembrar que estas atividades nào podem ser definidas e implantadas aleatoriamente, visto que existe uma ordem de abordagem resultante das dependèncias existentes entre elas. Assim, deve-se $\mathrm{cm}$ primeiro lugar definir os requisitos para documentação. Posteriormente, deve-se de definir processo de execução da verificação e os critérios das revisōes. Por fim. deve-se definir o processo de gerência da configuração. Sugestōes para a instanciaçāo de cada uma destas atividades são apresentadas, respectivamente, nas Seçōes 8.5.1, 8.5.2 e 8.5.3.

\subsubsection{Documentaçāo}

Como foi citado na Seção 8.3.2, sugere-se que a documentaçāo dos componentes seja o primciro tópico a ser abordado no processo de introduçào do reúso. Isto porque uma boa 


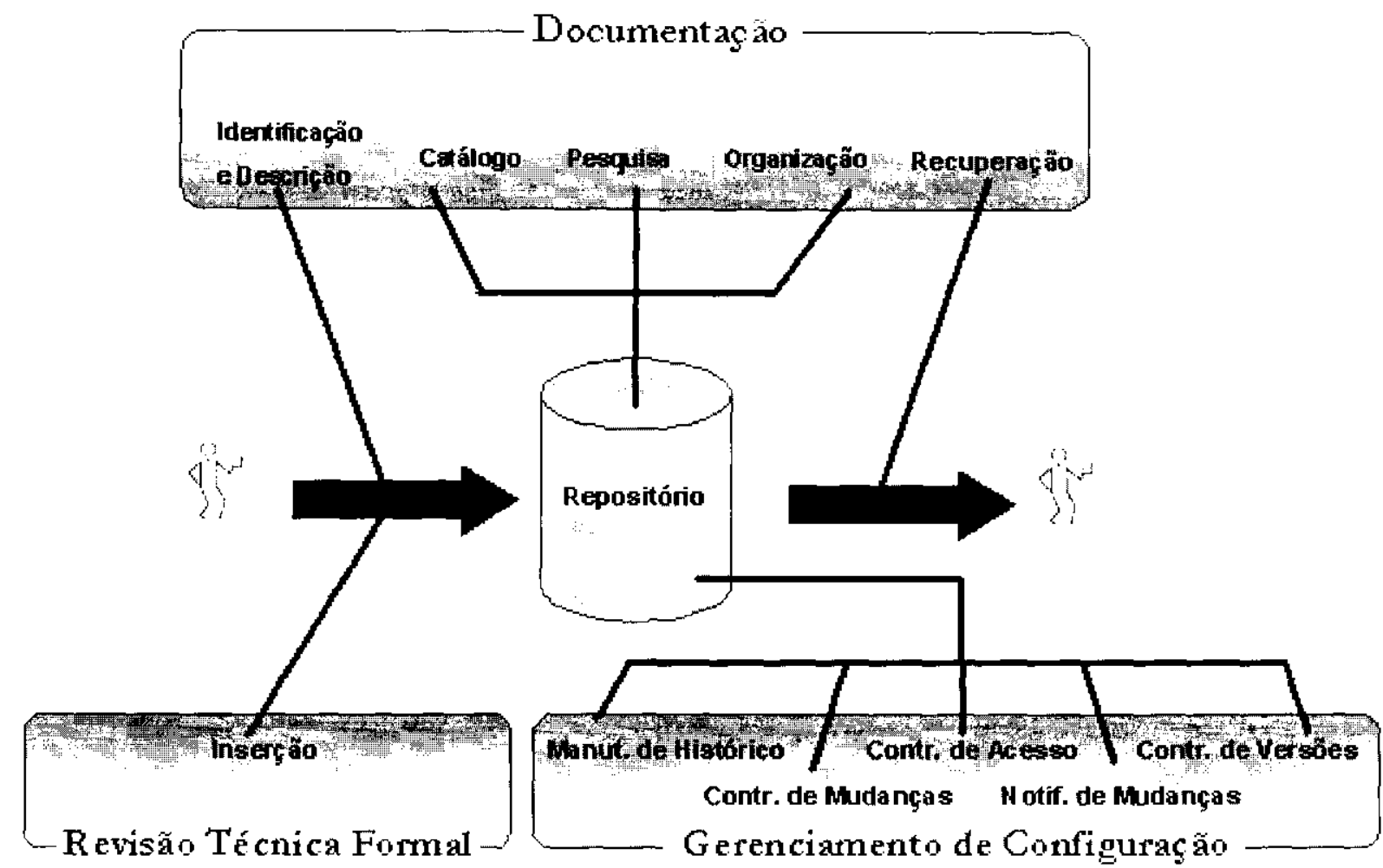

Figura 8.4: Relação Entre as Funcionalidades do Repositóio de Componentes e a Docu. mentaçào, a Revisão Técnica Formal e o Gerenciamento de Configuraçāo

documentação é de suma importância/utilidade no processo de classificação. avaliaçāo, recuperação e uso de componentes.

As vantagens obtidas por uma organizaçāo pelo uso de unra documentaçāo de qualidade foram apresentadas no Capítulo 5, assim como as dificuldades que muitas vezes se onfrenta ao tentar implantá-la. Assim, a reunião de definiçāo dos requisitos para documentação já pode apresentar pontos de divergência de opiniōes entre os integrantes do grupo de trabalho. É importante, entāo, apresentar a eles todas as vantagens de uma boa documentação e os problemas decorrentes da sua inexistencia. Esta tarefa cabe ao engenhciro de software. Por outro lado, é preciso que o mesmo tenha $\mathrm{cm}$ mente, durante a construção das diretrizes para documentação, a quantidade de trabalho que as mesmas exigirão dos desenvolvedores caso sejam implantadas e seja razoável em suas propostas. Valc ressaltar que nem todas as modificaçōes julgadas necessárias precisam ser implantadas de uma só vez. Seguindo a estratégia de melhoria contínua deste trabalho, o grupo pode optar por inicialmente implantar apenas pequenas mudanças e, com o decorrer das "rodadas" no ciclo de definiçōes implantar alteraçōes mais amplas. Desta maneira, o grupo pode mostrar 
aos desenvolvedores as vantagens que a implantaçāo de uma boa documentação os trouxe. justificar novas alteraçōes e melhorar a receptividade às mesmas.

O modelo inicial de referência para documentaçāo proposto neste trabalho divide as tarefas de documentaçāo em dois tipos: atividades referentes à documentação interna (ou documentação do código-fonte) e atividades referentes à documentaçāo cxterna dos componentes. Vale lembrar que no caso deste trabalho, cada classe (e seus respectivos métodos) de um desenvolvimento orientado a objetos constitui um componente, o qual deve estar implementado em um único arquivo.

Antes de apresentar as diretrizes para documentaçāo sugeridas, é preciso que se esclareça que quando se fala sobre obrigatoriedade de uma tarefa ou requisito, isto não quer dizer que sua implantaçāo na organizaçāo é indispensảvel, mas sim que, se a organização optar por implantá-lo, ele deve ser obrigatoriamente seguido pelos descnvolvedores. Além disso, vale ressaltar quc o uso do termo obrigatório para algumas tarefas e requisitos foi uma sugestão obtida e validada no estudo de caso.

\section{Requisitos para a Documentação Interna}

Para a documentaçāo interna (código-fonte) dos componentes, sugere-se que os seguintes requisitos sejam implantados:

\section{Identificação do Código}

Deve ser colocada no início do arquivo $\mathrm{cm}$ forma de comentário e deve conter as seguintes informaçōes:

- Informaçōes Obrigatórias:

- Nome da classe:

- Autor(cs) da classe original;

- Data de criação da classe original (primeira versão)

- Funçāo global da classe:

- Dominio (para revisão) da classe;

- Palavras-chave da classe:

- No caso de sub-classes, classe(s) base(s);

- Versão (autor(es) c data):

- Breve explicação da diferença entre a versāo anterior c a atual (mantendo assim um breve histórico das alteraçōes). exceto para a primeira versāo do componente; 
- Descrição das pré c pós-condições para execução desla classe.

- Informacōes Facultativas:

- Breve explicacāo do motivo da alteraçāo, exceto para a primcira versāo do componente:

- Suposiçōes que tenham sido feitas:

- Observacōes consideradas relevantes como. por exemplo, momentos/propositos/contexto do processo no qual a classe pode ser utilizada, programas relacionados, restrições. informaçòes manipuladas/ encapsuladas. object oriented design pattern (Gamma, Helm. Johnson, \& Vlissides 1995) seguido. entre outras.

\section{Identação}

Realizar a identaçāo do código utilizando-se quatro espaços, obrigatoriamente.

Vale ressaltar que a existencia de muitos niveis de codigo (de mancira que, quando se realiza a identação. este código ultrapasse o limite de caracteres por linha) indica que deve-se reconstrui-lo, re-agrupando algumas tarefas em novos metodos.

A identação do código deve possuir, obrigatoriamente, no maximo, quatro niveis fum número maior de níveis indica que o côdigo está muito complexo), sendo aceitas apenas excecôes devidamente justificadas através de comentảrios.

\section{Comentários}

Nlém dos comentários que devem ser inseridos no inicio da classe tratado no item 1 , deve-se, obrigatoriamente, utilizá-los para:

- Definir pré e pós-condiçōes, autor(es), data de criação, palavras-chave e funçāo (única) dos mélodos no início dos mesmos:

- Apresentar no inicio dos métodos os parâmetros que ele recebe, incluindo informaçoes quánto ao tipo de passagem utilizada (passagem por valor, por referência ou por ponteiro, sendo que neste último tipo deve-se também explicitar o que está sendo apontado, referenciadol, o tipo do parâmetro (entrada/saida) e o valor de retorno do método;

- Para explicar o significado/proposito de uma variável quando for impossivel explicitá-lo através de seu nome: 
- Realizar a documentação das partes mais complexas do código, focando-se cm "o quc" ć fcito. c não "como" é feito. Comandos condicionais, de repetição c comandos aninhados devem merecer maior atenção no que tange à documentação. Ressalta-se mais uma vez que a existéncia de muitos nivcis dificulta o entendimento do código.

Estas informaçōes devem ser sucintas e claras, e devem ser cscritas, obrigatoriamente, antes do código que descrevem

\section{Nomenclatura}

Deve-se definir uma nomenclatura padrão e obrigatória para nomes de classes, métodos, variávcis e constantes. alćm de outras cstruturas tipicas da linguagem utilizada (como Interface em Java, por exemplo).

Uma sugestão para esta nomenclatura padrão, extraida do estudo de caso deste tra balho, é:

- Classe: palavras iniciadas em letra maiuscula (ex: C45ToStdrule);

- Método/Variável: palavras iniciadas em letra miníscula, separadas pclo caractere _ (ex: c45_to_stdrule);

- Constante: palavras em letras maiúsculas, scparadas pelo caractere _ (ex: C45_TO_STDRULE).

Vale ressaltar que todo nome deve ser significativo frente ao que deseja representar. Geralmente, nomes de classes e variảveis são substantivos enquanto os nomes dos métodos são iniciados com um verbo.

Outras sugestōes de nomenclatura podem ser encontradas em Sun (1999) e Lewandowski $(2000)$

\section{Classes, Métodos e Sub-Classes}

Deve-se considerar para classes, métodos c sub-classes, as seguintes regras (obrigatórias):

- Uso de nomes representativos de sua função:

- Uso de parâmetros c variáveis com nomes tambèm significativos;

- Definir ou declarar no inicio do mé1odo/classe todas as variáveis a serem utilizadas no código: 
- Não utilizar variáveis globais:

- Cada método deve realizar uma só função e deve ser pequeno, quando possivel. Recomenda-se que cada método tenha menos que trinta linhas;

- Descrever os paràmetros de entrada (dados fornecidos ao programa), os parametros de saida (dados produzidos pelo programa) e o valor de retorno do método.

\section{Tamanho das Linhas}

Deve-se evitar linhas de código que ultrapassem o limite de caracteres da tela. Quando isto não for possivel, a quebra das linhas deve ser feila, obrigatoriamente, de mancira a seguir os seguintes criterios:

- Qucbra após uma vírgula:

- Quebra antes de $u$ m operador logico;

- Identar a nova linha em relação à linha anterior. Deve-se definir um padrão para esta identação. Por exemplo, identá-la com o início do parêntese de condição ou chamada a método;

- No caso de expressòes aritméticas. realizar a quebra fora de uma expressão entre parênteses.

\section{Linhas em Branco}

Deve-sc obrigatoriamente utilizar uma linha em branco entre as definicóes de métodos, entre as declaraçöes das variáveis e o primeiro comando, antes de uma linha ou bloco de comentários e entre as partes lógicas de um método para facilitar a leitura do código.

\section{Espaços em Branco}

Deve-se utilizar, obrigatoriamente, espaços em branco nas seguintes situaçōes:

- Entre uma palavra chave e um parêntese:

- Em conversões de tipo.

Nas seguintes situaçós, o uso de espacos cm branco é facultativo. embora fortemente recomendado:

- Depois de uma virgula ou de um ponto-e-virgula; 
- Em operadores binários, mas nunca em opcradores unârios;

- Entre as expressōes de uma lista, como por exemplo no comando for.

\section{Declarações}

As declarações devem, obrigatoriamente, ser feitas scmpre no início da classe/ subclasse/método. Além disso, as seguintes regras devem ser obrigatoriamente seguidas:

- Deve-se rcalizar uma declaraçāo em cada linha de maneira a permitir a inclusăo de comentário explicando, por exemplo, a informação que uma variâvel represental

- As inicializaçõcs que forem necessárias devem ocorrer no inicio do programa. exceto para aquelas variáveis que possuem o seu valor inicial dependente de alguma computação;

- Não rcalizar a inicialização de mais de uma variável em um mesmo comando, como, por exemplo, a $-\mathrm{C}=\overline{\mathrm{a}}-\mathrm{e}-\mathrm{f}_{;}$;

- Declaraçōes de tipos ou estruturas devem ser comentadas;

- Evitar declaraçōes de variáveis com funcionalidades diferentes, ou seja, que representam elementos diferentes. em escopos diferentes, mas com nomes iguais.

\section{Comandos de Início e Fim de Bloco}

Deve-se definir um padrão obrigatório para a formataçāo dos comandos de inicio e fim de bloco. Uma sugestão para este padrāo è o uso destes comandos sempre na seguinte formatação:

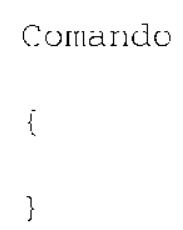

Deve-se também obrigatoriamente utilizar os comandos de inicio e fim de bloco, principalmente en comandos condicionais ou de repetição, a fim de evitar problemas na introduçāo de novos comandos.

\section{Comandos}

Comandos simples devem obrigatoriamente aparecer sozinhos em cada linha (evitar. por exemplo, fazer: $a++; c_{++}$). 
Comandos compostos devem obrigatoriamente ser identados de acordo com o padrão estabelccido.

\section{Tratamento de Erros}

Deve-se definit como deve acontecer, obrigatoriamente, o tratamento de crros. Alcm disso, no tratamento de erros deve-se especificar, atraves de comentários. as condiçōes para ocorréncia de um determinado erro e a aşāo a ser tomada.

\section{Parênteses}

Deve ser obrigatório o uso incondicional de parénteses em expressōes aritméticas ou lógicas. mesmo que a ordem correta de execução da expressāo esteja implicita na precedência dos operadores. Com isso pode - se cvitar problemas na compreensão da expressāo c na sua alteração. caso necessiário.

\section{Idioma}

Deve ser escolhido um idioma no qual todo o codigo deve ser obrigatoriamente escrito. incluindo comentários e nomenclatura.

\section{Hierarquia}

Todo componente obrigatoriamente deve cstar classificado $\mathrm{cm}$ um dos niveis de $1 \mathrm{ma}$ classificaçào hierárquica previamente estabelecida pelo grupo de rabalho. Quando nāo for possivel fazê-lo, deve-se cntrar cm contato com o responsável pela classificação que estará encarregado de resolver o problema (possivelmente criando um novo nivel ou selecionando o nivel mais adequado para o componente).

\section{Diretrizes para o Desenvolvimento de Código Orientado a Objetos Visando o Reú-}

so

$\Lambda o$ se desenvolver codigo em linguagem oricntada a objetos. deve-se seguir, obrigatoriamente, as seguintes regras (Karlsson 1995) ${ }^{1}$ :

- Nào utilizar herança múltipla apenas para diminuir código. O uso de herança múlipla torna o código mais dificil de ser entendido;

- Métodos a serem reescrilos nas subclasses devem ser virtuais. Isto faz com que o descnvolvedor que irá reulilizar o código conheça quais métodos devem scr redefinidos:

'Karlsson (1995] apresentld tumitas ditctrizes para o desenvolvimento de componentes orientados a objelo. abordando desde a fase de analise ate a fase de teste. 
- Nas sub-classes, manter separados os métodos novos dos métodos redefinidos;

- Não realizar conversão de tipos de um objeto de uma classe superior para uma classe inferior na hierarquia, ou seja, da classe base para a classe derivada. desnecessariamente. Isto pode criar dependèncias na hicrarquia c a nccessidadc de se administrar cxtensivamente os tipos de objetos;

- Tentar evitar o uso de herança com cancclamento, ou seja, a situação na qual a classe derivada restringe os métodos que irá herdar, tornando a interface entre a classe e a sub-classc menos clara. Em $\mathrm{C}^{+-}$, está situação é simulada com o uso de herança privada:

- Manter as classes pequenas, com poucos mėtodos. Recomenda-se que o número de métodos nāo passe de vinte e cinco, incluindo métodos herdados;

- Manter as sub-classes pequenas, evitando a introdução de muitos novos métodos, não provenientes da herança. Recomenda-se a inclusão de não mais que dez métodos:

- Manter o número de parâmetros dos métodos pequenos. Recomenda-se menos de cinco parāmctros por método:

- Manter os métodos pequenos, com menos de trinta linhas;

- Declarar métodos como constant quando possivel, informando ao desenvolvedor quais métodos não modificam o estado da classe;

- Declarar parâmetros como constant quando possivel, informando quais parâmetros nāo sāo modificados na implementação do método;

- Nāo checar o tipo de um objeto para não criar dependèncias desnecessárias. Utilizar polimorfismo nestes casos;

- Especificar os atributos como private, escondendo a representaçāo dos dados e mantendo a interface estável, independente de modificaçoes nesta representaçāo:

- Utilizar métodos protected ao invés de atributos protected na classe base. Utilizando uma interface de métodos, as representacōes de dados internas podem ser modificadas sem afetar as sub-classes:

- Evitar utilizar friends, se possivel. Este conceito viola o encapsulamento e torna o reúso mais difícil. É preferível o uso de métodos friends ao invés de classes friends. 


\section{Particularidades}

É importante que sejam especificados requisitos particulares a linguagem e técnica utilizadas para construir o componente. Por exemplo, a linguagem Perl permite o uso do comando use strict, cuja função é, dentre outras, nāo permitir o uso de uma variavel sem a sua prêvia declaraçäo. A partir da exigência do uso deste coman do. pode-se facilitar bastante a construção, o teste e a manutençāo de componentes escritos em Perl.

\section{Exemplo}

Recomenda-se a apresentação, no documento que descreve o padrão adotado, de um ou mais componentes que exemplifiquem todos os requisitos definidos, de mancira a ilusträ-los aos desenvolvedores.

\section{Requisitos para a Documentaçõo Externa}

Para a documentaçäo externa dos componentes. sugere-sc o uso de um conjunto minimo de informaçōes. sendo este conjunto dividido em informações sobre as classes e sobre os seus respectivos métodos. Na Tabela 8.1 ć apresentada uma listagem das informações sugeridas para as classes e suas respectivas cardinalidades. ou seja, se podem existir zero. uma ou mais respostas para a informação. Na Tabela 8.2 é apresentada a listagem das informaçōes referentes a cada um dos metodos da classe. acompanhada também de. sua respectiva cardinalidade.

\begin{tabular}{|c|c|}
\hline Informação & Cardinalidade \\
\hline Nome da Classe & 1 \\
\hline Versào & 1 \\
\hline Autor(es) & $1 . . N$ \\
\hline Data de Criaçào & 1 \\
\hline Dominio (área de atuaçāo para revisão) & $1 \ldots \mathrm{N}$ \\
\hline Super-Classe (somentc para sub-classe) & $\mathrm{O} . \mathrm{N}$ \\
\hline Classificaçāo Hierárquica & 1 \\
\hline Código-Fonte (diretório onde o arquivo & 1 \\
\hline \multicolumn{2}{|l|}{ contendo o código-fonte está gravado) } \\
\hline Funcionalidade Principal & 1 \\
\hline Contexto de Uso & $1 . . \mathrm{N}$ \\
\hline
\end{tabular}




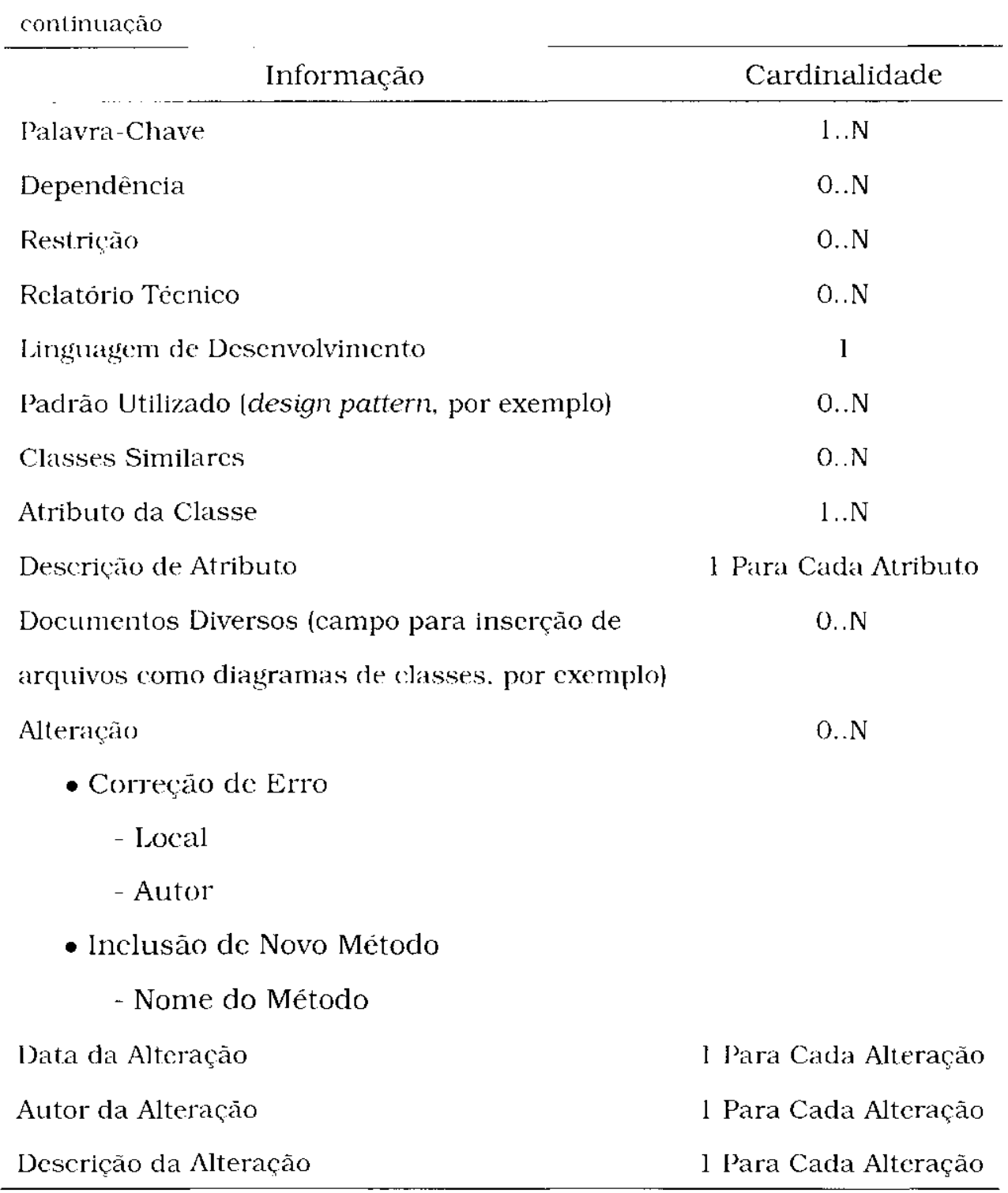

Tabela 8. 1: Informaçōes Refcrcntes às Classes

\begin{tabular}{lc}
\hline \multicolumn{1}{c}{ Informação } & Cardinalidade \\
\hline Nome do Método & 1 \\
Autor(es) & $1 . . \mathrm{N}$ \\
Data de Criação & 1 \\
Funcionalidade do Método (unnica) & 1 \\
Pré-Condiçōes para Execução do Método & $0 . . \mathrm{N}$ \\
Pós-Condiçōes para Execução do Mćtodo & $0 . . \mathrm{N}$ \\
Parâmetro de Entrada & $0 . \mathrm{N}$ \\
\hline
\end{tabular}

continua na próxima página... 
continuaçă

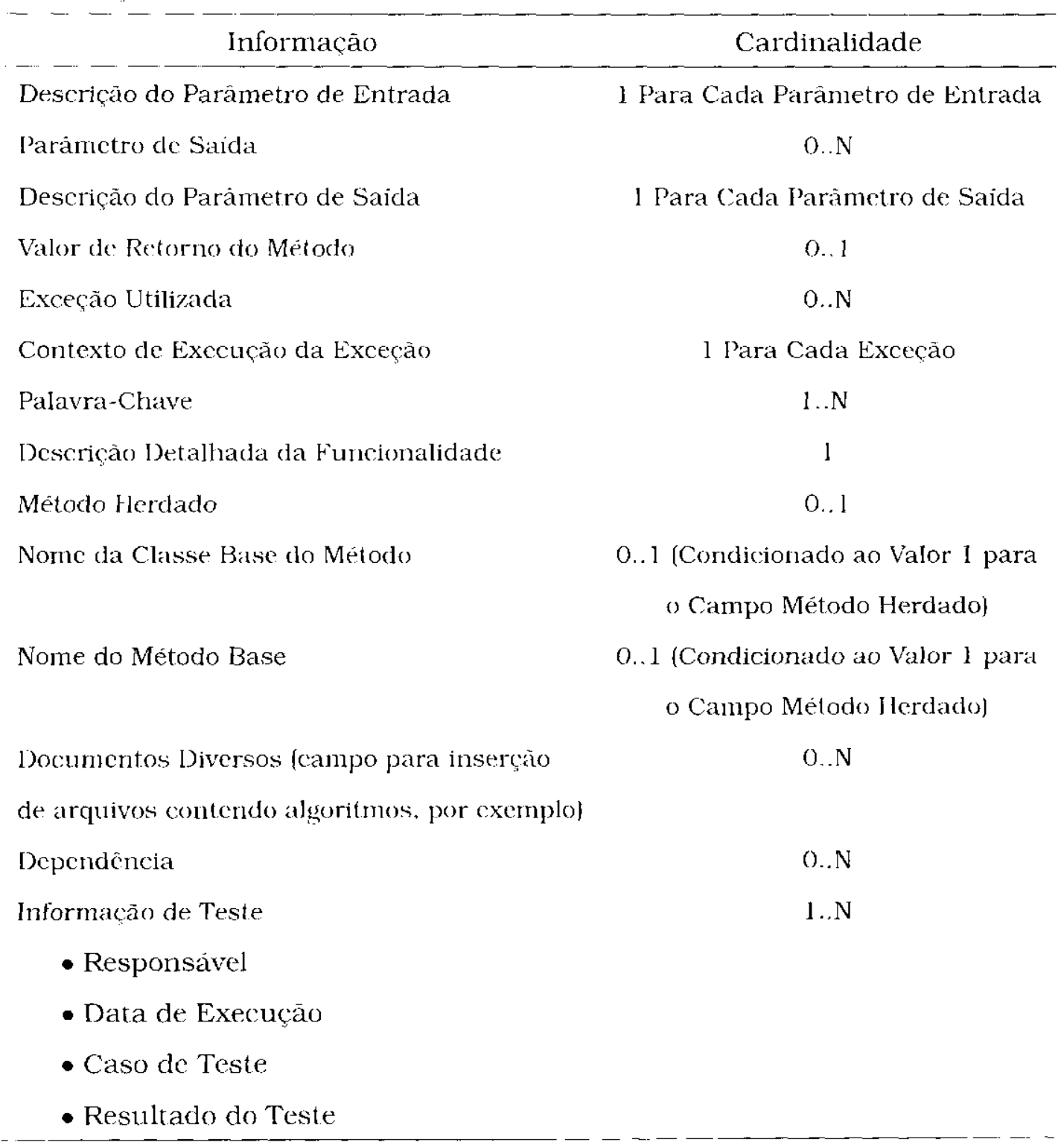

Tabela 8.2: Informaçós Referentes a Cada Um dos Métodos de Uma Classe

Nas Tabelas 8. I e 8.2, os campos intitulados Documentos Diversos têm como propósito o armazenamento dos caminhos dos diretórios onde estäo gravados arquivos contendo informaçöes extras sobre as classes e metodos, respctivamente. Vale ressaltar que somente estes arquivos devem estar armazcnados nos diretórios apresentados. Tais arquivos devem ser mantidos sobre controle de versão e devem ter sua modificaçāo exigida em caso de alteração da classse.

É importante explicar que as informações da Tabela 8.2 devem ser fornecidas para cada método. Assin, na informaçào Mètodo Herdado e nas três scguintes (referentes também ao) 
método herdado) da mesma tabela, a cardinalidade tem valor zero ou um para retratar. respectivamente, se o método documentado é ou năo originado de um outro e as informaçōes referentes a este método base.

Consideraçōes Gerais sobre a Documentaçāo

Sugere-se o uso dos atributos apresentados na Tabela 8.3 para busca dos componentes.

\begin{tabular}{ll}
\hline \multicolumn{1}{c}{ Classe } & Método \\
\hline Nome & Nome \\
Autor(es) & Autor(es) \\
Data de Criação & Data de Criação \\
Funcionalidade & Funcionalidade \\
Contexto & Descrição Detalhada da Funcionalidade \\
Palavras-chave & Palavras-chave \\
\hline
\end{tabular}

Tabela 8.3: Atributos Sugeridos para Uso na Busca por Componentes

Existem algumas recomendaçócs apresentadas na literatura que, como foi citado anteriormente, interferem na qualidade da documentação que foram contempladas neste trabalho. Algumas delas são:

- Todas as informaçōes consideradas de extrema importância por Holanda. Souza. \& Mclo (2000), como citado na página 7, estão presentes nestas diretrizes:

- Estão também presentes nas diretrizes informaçōes que possibilitam a implementaçāo de algumas funçōes do repositório, sugeridas por IIolanda, Souza, \& Melo (2000) e apresentadas na página 17. São clas: identificaçāo c descrição dos componentes. catálogo, pesquisa textual, organização e recuperação:

- A existência de informaçôes relativas às palavras-chaves e à classificação hierárquica dos componentes permite a implementaçào de dois tipos de técnicas de classificaçāo para os mesmos (apresentadas na Seção 2.6. 1), facilitando assim sua recuperação;

- Diversas informações propostas por Yacoub, Ammar, \& Mili (1999) para caracterizacão eficiente de componentes (apresentadas na Seção 2.7) estão presentes nas diretrizes: 
- Todos os critérios de qualidade para código sugeridos de Sá (1997). e apresentados na Seçāo 2.8, sāo, de alguma forma, abordados nas diretrizes apresentadas:

- As caracteristicas de modularidade. completude, atualização e padronizaçāo apresentadas por Andexer (1998) como necessárias para uma documentação de qualidade (e descritas na Seçāo 5.4), sāo contempladas nas diretrizes sugeridas:

- De mancira simplificada, as diretrizes contemplam as informaçōes exigidas pelo padrão de qualidade descrito por Phoha (1997) c apresentado na Seçāo 5.5.

É importante que exista um formato padrāo (template) para o documento no qual serāo inseridas as informações refercntes à documentação cxterna.

\subsubsection{Verificação}

O segundo tópico a ser abordado pclo grupo de implantação do reúso é a definição de um processo para a execução de verificaçòes, realizadas através de revisöes técnicas formais. nos componentes e suas respectivas documentações. Com isso, pretende-se garantir que os componentes foram construidos de acordo com os critérios e padrōes estabelecidos na organizaçāo.

São várias as vantagens que uma organizaçāo pode obter com a execuçào de revisões técnicas formais, muitas destas apresentadas no Capitulo 6. Porém. estc processo demanda recursos humanos e tempo, os quais muitas vezes a organizaçāo não está disposta a fornecer. Assim, propōe-se que, inicialmente, as revisōes sejam bastante sinples, priorizando a verificaçăo dos componentes. Vale ressaltar que, segundo o processo proposto, as pessoas que nelc estivercm cnvolvidas não precisam estar integralmente dedicadas ao mesmo. Este tempo de dedicação deverá variar. no entanto, de acordo com o volume de revisōes a serem realizadas e com o nivel de complexidade dos componcntes a serem revisados. Assim. é importante incentivar o cumprimento dos requisitos exigidos e a qualidade dos componcntes para que menos revisōes sejam necessárias c que as mesmas sejam o mais simples possível.

Com base, entāo, nesta pequena disponibilidade de recursos, propōe-se como modelo inicial de referĉncia para as revisōes técnicas formais a cstrutura e o processo descritos a seguir.

É indispcnsável a cxistência de pessoas trabalhando na exccuçāo das revisões lécnicas formais. Assim, faz-se necessäria a cscolha de um conjunto de desenvolvedores de diversos dominios de atuação da organização que estarāo cncarregados de realizar as revisōes nos 
componentes, assumindo cntão o papel de potenciais revisores, ou seja, pessoas que, após treinadas. estarão aptas c poderāo cntão ser convocadas para revisar componentes. Além disso, é preciso que se defina quem assumirá o papel de coordenador das revisōes e quais serão as áreas de atuaçāo (para revisão) de cada um dos potenciais revisores.

Como foi apresentada a necessidade de existēncia de um coordenador de revisões, é preciso que se especifique. entāo, quais scrāo suas responsabilidades. Assim sendo, o coordenador de revisão será responsável por identificar a existéncia de componentes para revisāo c sclecionar, para cada 1 m destes componentes, o grupo de revisores que o analisará, além de especificar. dentre eles, quem scrá o lider da revisāo. Este líder, por sua vez, será responsảvel por agendar (data/hora/local) c conduzir as reuniōes de revisão. Além disso, em cadá reuniāo deve-se selecionar um dos revisores para assumir a responsabilidade de anotar todas as questōes importantes discutidas, excrendo assim o papel de sccrctário.

Cada componente deverá ser revisado por dois ou mais revisores com conhecimento no dominio abordado pelo componente. Ressalta-se ainda a necessidade da existência de um revezamento na distribuição das revisōes aos revisores a fim de que nenhum deles tique sobrecarregado com esta atividade. Na reuniāo de revisão, deverão estar presentes todos os revisores do componente (incluindo o líder da rcvisāo) e o descnvolvedor do mesmo.

As revisões deverão ainda ser conduzidas em reuniōes plancjadas c controladas, durando, no máximo, duas horas. Alêm disso, cada rcuniāo deve ter seu foco em um componente (ou scja, uma única classe c scu conjunto de métodos) e sua respectiva documentação externa. É preciso ressaltar que os revisores selecionados para um determinado componente devem preparar-se previamente para a reunião, ou seja, cabe a cada um deles adquirir e analisar previamente a documentaça interna c cxtcrna do componente a ser avaliado. Espera-se que esta preparaçāo leve em torno de uma a duas horas. Além disso. as recomendacòes apresentadas na Seçāo 6.4 sāo válidas também neste processo.

O processo de verificação inicia-sc quando o desenvolvedor do componente terminar o seu desenvolvimento. A este componente deve ser associado um status, cujo valor, neste caso, deve ser AR - Aguardando Revisāo.

Cabe ao coordenador de revisào, periodicamente (periodicidade a ser decidida de acordo com as necessidades da organização), verificar se existem componentes com status AR e selecionar, para cada um deles, seus revisores e o líder da revisāo. Precisa-se definir alguma forma textual para que o coordenador da rcvisāo informe aos revisores que foram 
selecionados para revisar um determinado componente, ressaltando qual deles será o lider da revisão. Um mecanismo que pode ser utilizado para este lim c o aviso por e-mail.

'lendo o revisor sido informado de que é o lider da revisào de um determinado componente. o mesmo devera entrar em contato com o desenvolvedor e com os outros revisores para marcar uma data para a realização da reunião de revisāo. É ainda responsabilidade do líder da revisão: estabelecer uma agenda para a reuniāo, comunicar aos outros revisores o dia/hora/local da reunião de revisão, alem das responsabilidades de um revisor comum. Cada revisor, depois de receber a notiticação de que foi escolhido para revisar um determinado componente, deve obter a documentaçāo do mesmo e analisála para. náa reuniāo, somente apontar os problemas encontrados.

O processo de disponibilizaçāo do componente para verificação é ilustrado na Figura 8.5 .

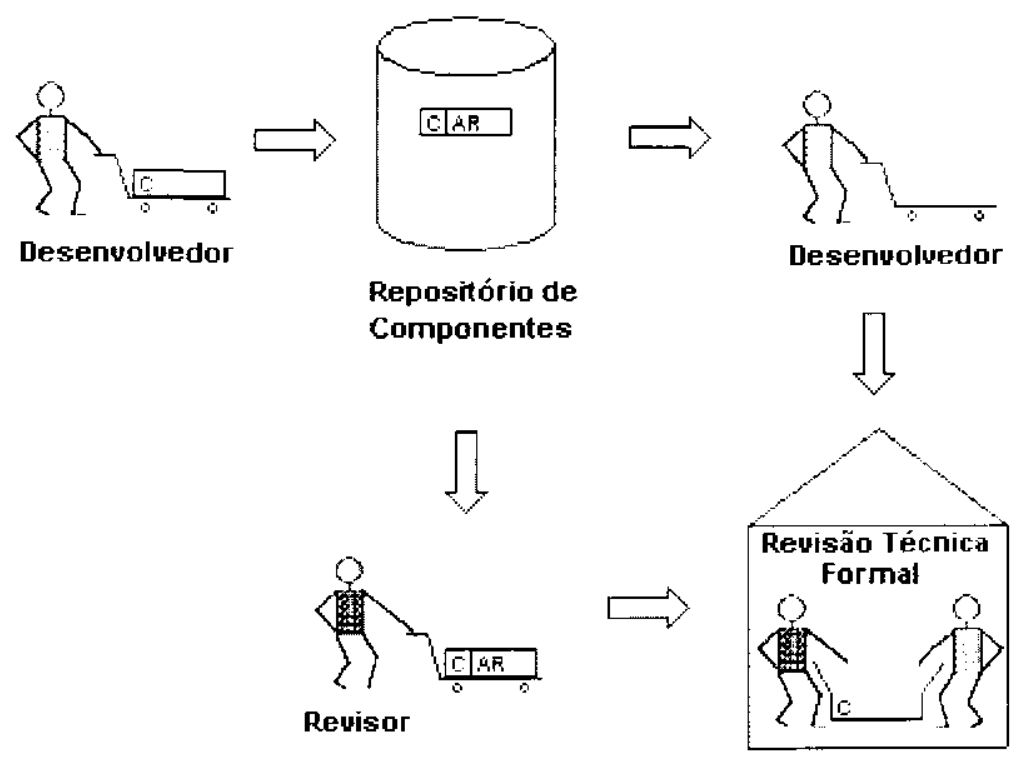

Figura 8.5: Disponibilizacão dos Componentes para o Processo de Verificação

A reunião deve começar com uma breve discussão de sua aggenda e uma introdução do componente a ser avaliado. Cabe ao revisor com papel de secretairio anotar todas as questões importantes discutidas. Depois da introducão do componente deve-se levantar os problemas encontrados pelo(s) revisor(es) durante sua preparação. Todos os problemas que forem validados devem ser anotados.

No final da reuniào o componente pode ser accito sem modificação, rejeitado por possuir erros graves ou aceito provisoriamente. Todos os componentes devem poder ser recupe rados em uma buscä, porem, somente componentes aprovados sem restriçoes devem ter 
o seu reúso incentivado. No resultado das consultas, o status dos componentes deve ser apresentado.

Caso um componenle seja accito sem restriçôes. sem a necessidade de modificaçōes, scu status deverá ser modificado para AP - Aprovado. Este processo é ilustrado na Figura 8.6 .

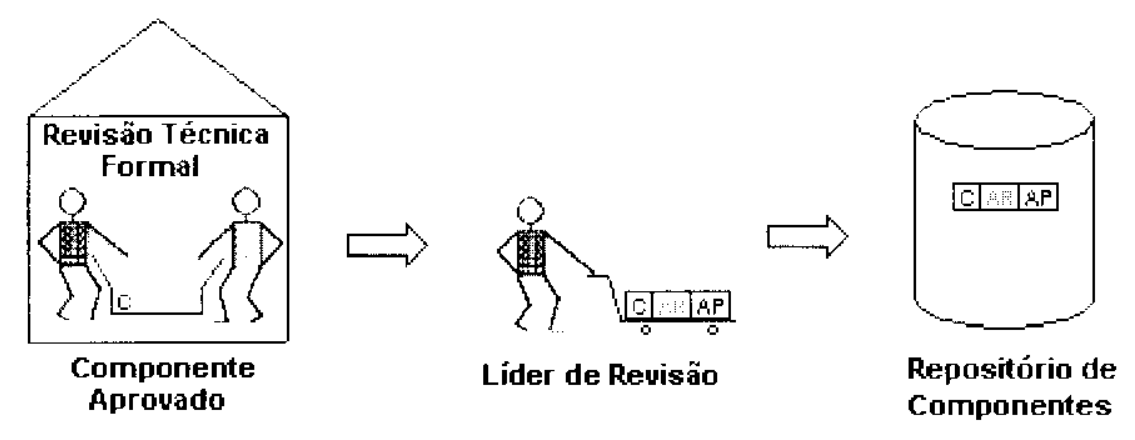

Figura 8.6: Componente Aprovado Sem Modificaçōes

Quando um componente não atende a todos os requisitos exigidos. porém atende a um grupo considerado essencial e tem urgência em ser disponibilizado. ele deve ser aprovado provisoriamente. Nestc caso, o status do componente deverá ser alterado para AC Aguardando Correção.

O desenvolvedor do componente deverá ter então um tempo máximo, a ser estipulado pela orơanizaçăo, para realizar as correçoes necessárias. Passado este período, o grupo pode adotar algum tipo de politica, como, por exemplo, avisar ao desenvolvedor que se o componente não for atualizado dentro do prazo, ele será definitivamente reprovado. Caso o componente não seja mesmo atualizado, ele deve receber o status RP - Reprovado. Caso contrário, isto é. se o componente for corrigido, reinicia-se o processo verificaçāo, ou seja, o mesmo deve ser novamente documentado e submetido a revisão, como se fosse uma nova versāo do componente. O processo de atualizaçāo do componente pode ser visualizado graficamente na Figura 8.7 .

É importante lembrar que um componente com status AC poderá ser apresentado em uma consulta e até mesmo recuperado do repositório de componentes. Porém não recomendase que cle scja reutilizado. Desenvolvedores que optem por fazê-lo deverão estar cientes de que esta nāo é uma versāo "reutilizável" c que, possivelmente, deverá ser atualizada. 


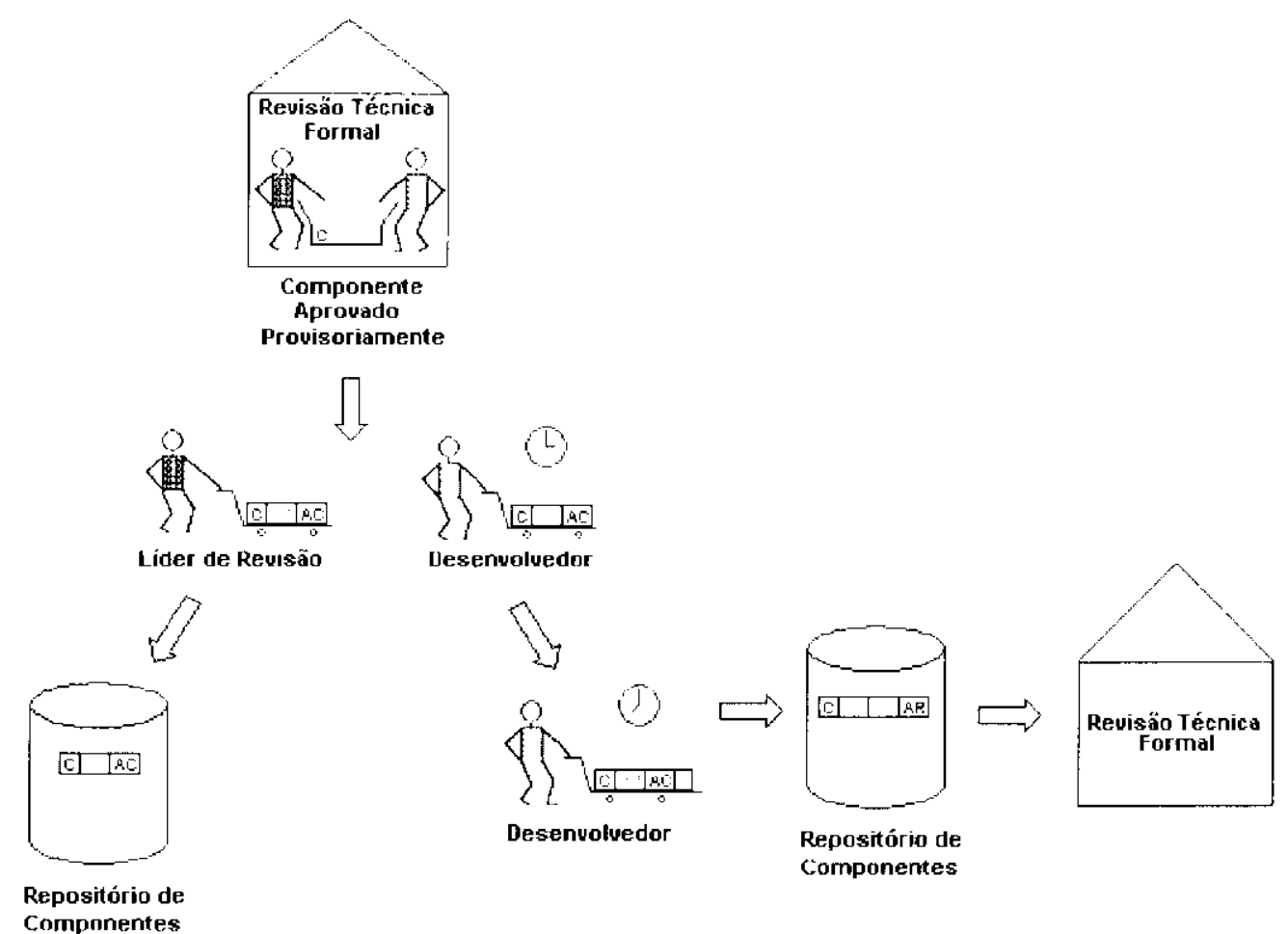

Figura 8.7: Componente Aprovado Provisoriamente

Os componentes que nāo apresentarem nem mesmo os requisitos considerados essenciais não deverão ser aceitos e deverāo receber o status RP - Reprovado. Estc processo ć ilustrado na Figura 8.8 .

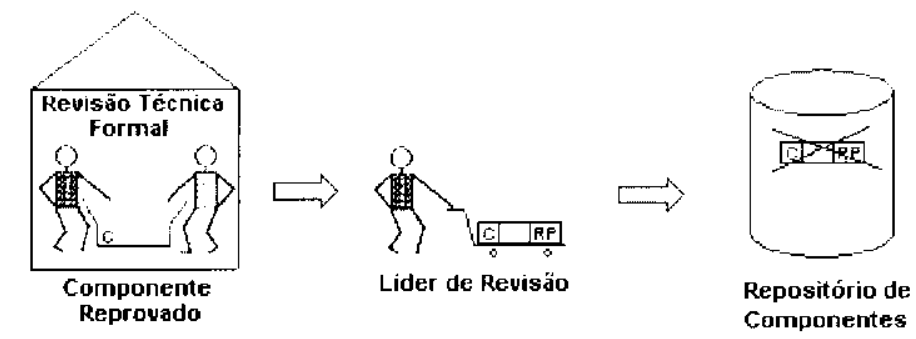

Figura 8.8: Componente Reprovado

Cabe ao líder da revisāo alterar o status do componente após a sıa avaliação.

Ao final de cada revisão deve ser gerado um documento contendo o nome do componente quc foi avaliado, sua versāo ou branch ${ }^{2}$. os participantes da revisão, a data da rcvisão, o parecer dado ao componente (aprovado. aprovado provisoriamente ou reprovado) e quais

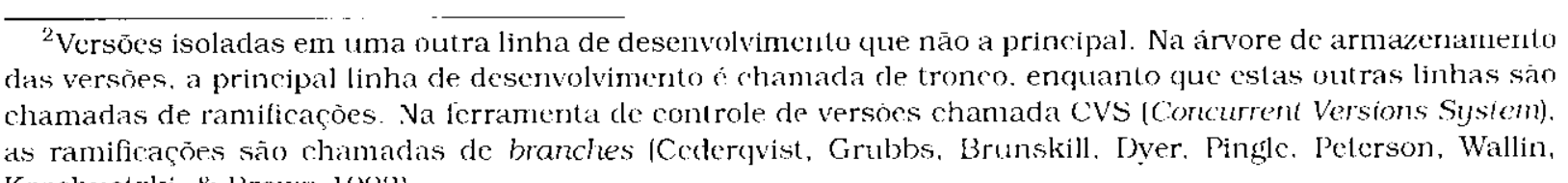
Koschuelzki. \& Brown 1992). 
são os pontos problemáticos (caso existam). A geração deste documento tambèm è de responsabilidade do líder da revisão.

Vale ressaltar que o processo de verificação é o mesmo tanto para novos componentes como para novas versōes dos mesmos, sendo que novas versōes somente poderāo scr autorizadas para componentes já existcntes e com status aprovado. A re-documentaçāo de componentes com status aprovado provisoriamente pode também ser considerada como uma nova versão do mesmo.

Devido a alta rotatividade dos desenvolvedores, caracteristica considerada na proposição destas diretrizes. é importante ressaltar a necessidade da existência de uma pessoa responsável pelo treinamento dos novos desenvolvedores. Neste trabalho, propóe-se que o responsável por tal tarefa, no âmbito das revisōes, seja o coordenador de revisāo. Estc coordenador deverá entāo treinar, quando necessário, novos revisores, novos lideres de revisão e novos coordenadores de revisão. Este treinamento deve ser realizado $\mathrm{cm}$ paralelo às ultimas semanas ou meses de trabalho do desenvolvedor que ira deixar a organização. integrando gradualmente o novo desenvolvedor às suas novas atribuições.

Vale ressaltar que o processo de exccução de verificação sugerido procura contemplar diversos pontos apresentados como importantes no decorrer deste trabalho como a garantia da conformidade com padrōes estabelecidos (página 24) e o fato de a documentação ser verificável (página 46), além de procurar manter o máximo fidelidade à tcoria apresentada no Capitulo 6 (referente à revisão técnica formal, mancira pela qual a verificação ć realizada segundo o que foi proposto).

\section{Critérios da Verificação}

Como citado anteriormente é preciso que exista um critério para aprovacāo dos componentes. Nlém disso, é preciso que se especifique quais requisitos são essenciais (cuja presença garante uma aprovaçáo provisória, temporária) c quais requisitos sāo exigidos (que englobam os requisitos essenciais e cuja prescnça garante a aprovaçáo total do componente).

Este trabalho considera como um requisito essencial e indispensável para a aprovação provisória do componente a necessidade de sua disponibilização aos desenvolvedores em caráter de urgência. Além disso, nas Tabelas 8.4 e 8.5 são apresentados os outros requisitos considerados essenciais aos componentes, referentes à sua documentacão externa $\mathrm{e}$ interna, respectivamente. 


\begin{tabular}{|c|c|}
\hline \multicolumn{2}{|c|}{ Requisitos Essenciais aos Componentes (Aprovaçào Provisoria) } \\
\hline \multicolumn{2}{|c|}{ Referentes à Documentaçāo Externa } \\
\hline Classe & Método \\
\hline Nome & Nome \\
\hline Versão & Autor(es) \\
\hline Autor(es) & Data de Criação \\
\hline Dala de Criaça & Unicidade da Funcionalidade \\
\hline Super-Classe (somente para sub-classes) & Descricăo da Funcionalidade \\
\hline Classilicação Hierárquica & Parämetro(s) de Entrada \\
\hline Código-fonte & Parämetro(s) de Saida \\
\hline Funcionalidade Principal & Palavra(s)-Chave \\
\hline Coritexto de Uso & Pré-Condição para Execução do Método \\
\hline Pré-Condição para Exccução da Classe & Pós-Condição da Execução do Método \\
\hline Pós-Condição da Execução da Classe & Documentos Diversos \\
\hline Palavra(s)-Chave & Informaçoes Detalhadas dos Teste \\
\hline Dependencia(s) & Documentacá Escrita no Idioma Padräo \\
\hline \multicolumn{2}{|l|}{ Atributo(s) da Classe } \\
\hline \multicolumn{2}{|l|}{ Domínio (árca de trabalho para revisāo) } \\
\hline \multicolumn{2}{|l|}{ Documentos Diversos } \\
\hline \multicolumn{2}{|l|}{ Alteração(ōes) } \\
\hline \multicolumn{2}{|l|}{ Data da(s) Alteraçāo(ōes) } \\
\hline \multicolumn{2}{|l|}{ Autor(cs) da(s) Alteraçào(ōes] } \\
\hline Documentação Escrita no Idioma Padrão & - \\
\hline
\end{tabular}

Tabela 8.4: Requisitos Essenciais Aos Componentes (Aprovação Provisória) Referentes à Documentação Externa

Requisitos Essenciais aos Componentes (Aprovacão Provisória)

Referentes à Documentaçāo Interna

Nome da classe

Autor(es) da classe original

Data de criação da classe original

Função global da classe

continuá na próxima página... 
rontinuação

Requisitos Essenciais aos Componentes (Aprovaçāo Provisória)

Referentes à Documentaçāo Interna

Palavras-chave da classe

Versào (autor(es) e data)

No caso de sub-classes, classe(s) basc(s)

Descrição das pré e pós-condiçōes para execucão desia classe

Definir pré e pós-condições, autor(cs), data de criação, palavras-chave c função (única)

dos métodos no inicio dos mesmos através de comentảrios

Seguir as regras de nomenclatura

Para Métodos e Classes

- uso de nomes representativos de sua finção global

- uso de parâmetros e variáveis com nomes também significativos

- declarar todas as variáveis a serem utilizadas no código e não utilizar variáveis

globais

- cada método deve realizar uma só função e deve ser pequeno, quando possivel (recomenda-se que seja menor que 30 linhas)

Realizar o tratamento de exceçóes de acordo com o estabelecido

Escrever o código e sua documentação no idioma padrão

Métodos a serem recscritos ou redefinidos nas sub-classes devem ser virtuais

Declarar métodos e parânetros como constant quando possivel

Especificar atributos como private

Sempre que possivel (excecòes devem ser devidamente documentadas):

- Manter as classes pequenas, com poucos métodos (menos de 25, incluindo métodos herdados)

- Manter as sub-classes perutunas. evitando a introdução de muitos novos métodos. não provenientes da herança (recomenda-se menos que 10 métodos novos)

- Manter o número de parámetros dos métodos pequenos (menos de 5 paràmetros)

- Manter os métodos pequenos (menos de 30 linhas)

Tabela 8.5: Requisitos Essenciais Aos Componentes (Aprovação Provisoria) Referentes à Documentaçào Interna 
Para que os componentes sejam totalmente aprovados é preciso que os mesmos sigam rigorosamente os requisitos definidos, tanto para documentação externa quanto para documentação interna. Vale ressaltar que rcquisitos nāo-obrigatórios mas fortemente recomendados, quando não cumpridos, deven ter tal posiçāo justificada. Além disso, merece atençào os requisitos da documentação externa cuja cardinalidade prevè a sua possivel inexistência (por excmplo, pode não existir relatório técnico que descreva uma determinada classe). É preciso que se verifique se o requisito não possui mesmo valor ou se o descnvolvedor simplesmcnte não se preocupou em preenchê-lo.

Pode também ser definido como condiçào para reprovaçāo de um componente um determinado número dè avaliacōes nas quais o componente nào foi totalmente aprovado.

Como inicialmente não é proposta uma inspeção quanto a corretitude do código apresentado, é de suma importância que os testes realizados no componente tenham abrangência suficicnte para cobrir todos os scus possiveis pontos de erro (é importante lembrar que o objetivo do teste é descobrir erros). Assim. o item referente a testes na documentaçào externa deve ser minuciosamente, cuidadosamente analisado a fim de que se garanta uma qualidade minima.

\subsubsection{Gerência de Configuração}

O terceiro c último tópico sugerido neste trabalho para ser abordado inicialmente no processo de introdução do rcúso engloba a atividade de gerência de configuração de software, cujo objetivo principal é coordenar o desenvolvimento de software de maneira a minimizar as dificuldades advindas das grandes modificaçōes que acontecem no decorrer do mesmo.

No caso do desenvolvimento baseado no reúso de componentes de softuare e na construção destes componentes, o controle das alteraçôs é também importante. Através deste controle consegue-se organizar o desenvolvimento de maneira que todos os interessados saibam quais são as diversas versōes de um componente, quais estão disponiveis e quais estāo scndo alteradas, quem está realizando estas alterações, onde encontrar as diversas versōes, entre outras informaçōes.

Um fator importante no gerenciamento de configuração é a existência de uma ferramenta que automatize o controle das versões armazenadas. Tal ferramenta, além de automatizar um controle que manualmente seria dificil de ser executado, tambeim permitc que todos os componentes c suas versôes estejam reunidos $\mathrm{cm}$ um único local de acesso controlado.

Como apresentado no Capítulo 7, muitas tarefas estāo envolvidas neste esforço para coordenar o desenvolvimento de software. Assim, é importante que se defina c documente 
quais sāo as atividades, como e por quem elas serāo exccutadas. Este é o objetivo do plano de gerenciamento de configuração de software. Este plano pode então ser definido como "um documento que descreve quais atividades devem ser efetuadas na implantação c na administração do processo de gerenciamento de configuração de softuare. Neste plano tambèm é descrito como e quando as atividades serão efetuadas, quem serão os responsáveis por elas e que recursos scrāo nccessários" (Pacheco 1997). Este plano deve ainda scr desenvolvido de acordo com as peculiaridades de cada organizaçāo. isto porque clc depende das metas e soluçōes alternativas específicas de cada ambicntc.

Como este trabalho aborda a introdução do reúso de componentes em ambientes com caractcrísticas semelhantes às de um laboratorio de pesquisa (ambiente do estudo de caso). o plano de gerenciamento de configuraçāo nele sugerido, c apresentado a seguir, toma como base a proposta de Pacheco (1997).

Vale ressaltar que o processo de gerência de configuração aqui proposto assemelha-se bastante a teoria apresentada no Capitulo 7. além de cobrir questōes importantes apresentadas na Seção 2.4, como a execuçāo de projeto piloto, treinamento, manutençāo do plano. entre outras.

A seguir, è apresentado um plano de gerenciamento de configuraçāo contendo as sugestöes propostas neste trabalho para serem implantadas inicialmente pelas organizaçōes. ou seja, um modelo inicial de referência para organizações que desejam iniciar seus esforços para implantaçāo da atividade de gerenciamento de configuraçāo. É importante salicntar que o conteúdo deste plano está em conformidade c considera a implantaçāo das atividades de documentação e verificação tal como apresentadas nas Seçôes 8.5.1 e 8.5.2, respectivamente, c, por este motivo. faz menção às mesmas.

\section{Plano de Gerenciamento de Configuração}

\section{Introdução do Plano}

\section{1 Propósito}

Este plano tem o objetivo de definir c orientar a implantação do gerenciamento de configuração de software em organizações $\mathrm{com}$ características semelhantes as de um laboratório de pesquisa. Nele são apresentadas informaçôes referentes às tarefás do gerenciamento de configuraçào, recursos e responsabilidades adaptadas à particularidades comuns deste tipo de organizaçāo.

\subsection{Escopo}


O processo de gerenciamento de configuraçāo aqui proposto é indicado para grupos de trabalho (pessoas com trabalhos inter-relacionados) cm organizaçōes com as seguintes caracteristicas:

- Poucos desenvolvedores:

- Falta de recursos ou indisponibilidade dos mesmos para aquisiçāo de gerenciadores de configuração proprietarios:

- Interesse na manutençào de um histórico do trabalho dos desenvolvedores c no controle das alteraçōes efetuadas cm seus programas;

- Intcressc no reúso de seus programas;

- Inexistencia de um organograma formal (gerente, diretor, desenvolvedor);

- Alta rotatividade dos desenvolvedores;

- Utilizaçào de poucas ou nenhuma prática pregada pela comunidade de Engenharia de Software no desenvolvimento de software;

- Adoção dos requisitos para construção de código e documentação externa, c do processo de revisão técnica formal apresentados nas Seçōes 8.5. 1 e 8.5.2, respectivamente.

\subsection{Palavras-Chave}

Árvore de Versōes: modo de descrever o histórico de versōes de cada item da configuraçāo.

Check In/Check Out: método de controle de itens da configuração armazenados no repositório. A operação de check out cria uma cópia de um determinado item da configuração no diretório de trabalho. Guando está operação é exccutada com a opção lock (ou seja, trava) o item copiado permanecerã bloqueado no repositório até que este usuário o armazcne novamente no repositório através da operaçào check in. A operação de check in, entāo, e responsável pela atualização do item de configuração no repositório de componentes. É importante ressaltar que estas atividades tem nomes e funções diferentes nas diferentes ferramentas de controle de versão. Esta definição toma como base a ferramenta Concurrent Versions System (Cederqvist, Grubbs, Brunskill. Dyer, Pingle, Peterson, Wallin. Koschuetzki. \& Brown 1992)

Configuração: conjunto de versōes de itens de configuraçāo consistentes, correspondente à determinada versão do sistema. 
Grupo de Desenvolvedores: grupo de pessoas que estcjam desenvolvendo componentes que estarāo sob o controle deste processo de gerenciamento de configuraçào.

Documentação: conjunto informaçoes c documentos que descrevem as caracteristicas dos componentes c estāo de acordo com os requisitos apresentados na Scçāo 8.5.1.

Gerenciamento de Configuração de Software: área da Engenharia de Software cujo objetivo é coordenar o desenvolvimento de software de maneira a minimizar a confusāo gerada pclas constantes alteraçóes nas informaçōes que são por ele produzidas.

Item da Configuração: produtos do desenvolvimento de software que foram selecionados para estar sob controle de configuraçāo.

Componente: arquivos de código-fonte a serem inseridos na ferramenta de controle de versão.

Linha de Referência (baseline): pontos ou momentos bem definidos no processo de desenvolvimento de software nos quais os itens sob controle de configuração săo identificados, analisados, corrigidos, aprovados e armazcnados no repositório.

Pedido de Alteração: documento que descreve autor, data, motivo e mudanças desejadas em um item da configuração.

Repositório: ferramentá de controle de versão de acesso controlado, na qual se armazenam itens da configuraçāo que já tenham passado por uma baseline.

Versão ou Revisão: situação de um item de configuração após uma alteração.

\section{Gerenciamento}

Deve existir um descnvolvedor responsãvel pelas atividades do gerenciamento de configuração aqui definidas. Devido à limitação de recurso pessoal, este desenvolvedor pode acumular as funçōes de coordenador do gerenciamento de configuração e do processo de revisão técnica formal. Como coordenador do gerenciamento de configuração, este desenvolvedor tem, basicamente, as seguintes responsabilidades:

- Criar uma estrutura para o repositório:

- Garantir a integridade do repositório através do controle de acesso (garantindo que nāo foram realizadas alteraçōes scm registro): 
- Realizar backup do repositório:

- Analisar os pedidos de alteração e, se necessário, liberar um item da configuraçāo para altcração;

- Gerar relatórios de situação da configuração. quando necessário:

- Resolver possíveis problemas de conflito de versōes. em conjunto com os autores das altcraçes. Este problema não deverá ocorrer se não forem autorizadas alteraçoes conflitantes:

- Inserir na ferramenta de controle de versão os componentes. e suas respectivas documentações. aprovados (definitivamente ou provisoriamente) na revisão técnica formal para que façam parte da configuraçāo de software;

- Treinar novos desenvolvedores para o assumirem o cargo de coordenador do gerenciamento de configuração, quando necessário. Vale ressaltar que este trei namento deve ocorrer simultancamente às suas ultimas semanas ou meses de trabalho:

- Treinar desenvolvedores no processo de desenvolvimento da organizacão, considerando atividades como revisāo técnica formal, reúso de componentes, entre outras atividades.

Vale ressaltar que algumas destas tarefas (como backup, por exemplo) podem ser automatizadas, sendo, no cntanto. responsabilidade deste coordenador. Com o decorrer deste plano, scrāo mclhor especificadas as responsabilidades do coordenador de con figuraçào.

Ao grupo de desenvolvedores cabe o fornecimento de todas as informaçōes a ele solicitadas e a execução das tarefas do gerenciamento de configuraça a ele atribuídas neste plano. Sāo atividades dos desenvolvedores, por exemplo, submeter seus programas ao controle de configuração, documcnta-los dcvidamente e solicitar alteraçōes quando estas forem necessárias, entre outras.

\section{Tarefas do Gerenciamento de Configuração de Software}

\section{1. Preparação para o Gerenciamento da Configuração de Software}

Esta tarefa envolve a seleçāo dos documentos que comporāo a configuraçào, a definição do momento a partir do qual estes documentos, agora chamados de itens da configuraçāo, serão controlados (baselines), a definição de nomes únicos para estes itens, além da forma como será organizado e manipulado o repositório. 


\section{- Seleção dos Itens que Irão Compor a Configuração}

Inicialmente ć sugerido que sejam colocados sob controle da gerència de configuração todos os códigos das classes desenvolvidas e suas respectivas documentaçōes. Como especificado nos requisitos para documentaçāo externa, podem ser anexados à documentaçāo diversos outros documentos como, por cxemplo, um diagrama de classes. Estes documentos também deverão ser mantidos sob controle de configuração, pois considera-se que estes sejam parte da documentação externa dos componentes.

\section{- Linhas de Referência}

As baselines, ou linhas de referēncia, são pontos bem definidos no ciclo de desenvolvimento nos quais os itens sob gerenciamento serāo identificados. analisados. corrigidos, aprovados e armazenados no repositório sob controle de acesso (da Rocha. Maldonado. \& Weber 2001). Estas linhas de referência, em ciclos de desenvolvimento tradicionais, podem ocorrer ao final de cada fase ou cm outros momentos definidos pela organizacão.

Vale ressaltar que, apos a passagem de um item de configuração por uma linha de referência, ele é considerado "baselined" e somente poderá ser al terado mediante aprovação formal de uma solicitação de mudança fcita ao gerente de configuração, cvitando assim inconsisténcias no repositório.

Neste trabalho, como considera-se apenas a etapa de codificação, sugere-se que a baseline da mesma scja o término do desenvolvimento do código, ou seja, após o término de uma classe, a mesma, em conjunto com sua documentacão externa, deve passar por uma revisão técnica formal. Se estes "documentos" forem aprovados (provisoriamentc ou definitivamente), eles devem ser inseridos na ferramenta de controle de versóes e. portanto, passar a fazer parte da configuraçāo, isto é. devem se tornar itens da configuração.

\section{- Identificação dos Itens da Configuração}

A nomenclatura dos itens da configuraçào do tipo código-fonte deverá seguir as regras de nomenclatura (incluindo o idioma padrāo) definidas na Seçāo 8.5.1. sendo que o arquivo deverá possuir o mesmo nome da classe que descreve (um arquivo deverá possuir somente uma classe)

O arquivo contendo a documentaçāo externa deverá possuir o mesmo nome do arquivo que contém a classe ao qual ela se referc. Os documentos anexa- 
dos à documentaçāo externa deverão possuir o nome do componente a que se referem seguidos pelo caractere _ c o nome original do arquivo.

Por exemplo, o arquivo de código-fonte que descreve a classe C45ToStdrule. escrita na linguagem Perl, deve se chamar C45ToStdrule.pm, sua documentaçăo externa deve possuir o nome C45ToStdrule.pdf, caso o arquivo que a contenha seja do tipo PDF, e o arquivo anexado de nome algorithm.txt deve ser renomeado para C45ToStdrule_algorithm.txt.

No caso de componentes a serem inseridos em branches, as regras de nomenclatura para os arquivos se maniem, scndo apenas precedida pela palavra BRANCH seguida do caractcre _. Por exemplo, o arquivo da documentaçào externa apresentado no cxemplo anterior, caso fosse aprovado provisoriamente. seria nomeado BRANCH_C45ToStdrule.pdf.

\section{- Organização do Repositório}

Deverá ser criado um repositório na ferramenta de controle de versões no qual deverāo ser colocados todos os itens da configuraçäo aprovados (provisoriamente ou definitivamente) no processo de revisão técnica formal.

Este repositorio deverá estar separado em diversos módulos e sub-módulos que reflitam a classificação hierárquica dos componentes, cuja definição fica a cargo da organizaçāo e è requisitada na Seçāo 8.5.1.

É importante ressaltar que o idioma utilizado para nomenclatura dos documentos, dos módulos c sub-módulos do repositório deve ser o idioma padrão (cuja definição também é requisitada na seçāo 8.5.1).

Os últimos niveis da classificaçào hierárquica do repositorio deverāo ainda ser divididos em sub-módulos, cada um delcs contendo um componente. Estes sub-módulos armazenarão, além do componente, toda documentação referente a ele, c deverāo possuir o nome deste componente. No caso de branches, estes devem ser nomeados pela seguinte regra: BRANCIInomedomódulo. Vale ressaltar que todos estes documentos, quando estiverem no repositório, já foram aprovados, ao menos provisoriamente, em uma revisāo técnica formal. Por exemplo, suponha quc. em uma organizaçāo cujo domínio de atuação é intcligência artificial, exista a classificaçāo Data Mining $\Rightarrow$ Conversion e que se deseja colocar sob ela o componente (com status aprovado) C45ToStdrule.pm e toda a sua documentação (C45ToStdrule.pdf c C45ToStdrule_algorithm.txt). 
Deve-se então criar o sub-módulo de nome C45ToStdrule c colocar dentro dele os arquivos desejados. Este exemplo está ilıstrado na Figura 8.9.

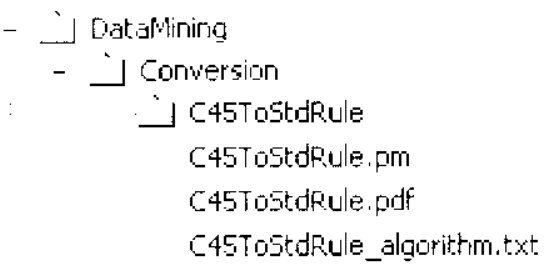

Figura 8.9: Exemplo de Estrutura do Repositório

Deve-se também freqüentemente fazer cópias de segurança do repositório (backup).

O responsàvel pela execução e manutenção de todas estas atividades c o coordenador do gerenciamento de configuração.

\section{- Relacionamento Entre os Itens da Configuração}

Toda alteração em um itcm da configuração do tipo código-fonte deverá resultar em uma consulta e. se necessária. modificação na documentaçāo que acompanha este ilem. Pelo processo aqui sugerido, esta deverá ser tambćm a única razāo para alterar uma documentaçāo externa. Assim, o número da versão do arquivo de código-fonte e dos arquivos da documentaçāo extcrna devem, obrigatoriamente, ser igual.

\subsection{Controle da Configuração}

Após a execução da revisão técnica formal do componente. se o mesmo for aprovado ou aprovado provisoriamente, o lider da revisão deverá disponibilizá-lo, em conjunto com sua respectiva documentação, para inserção no repositório. Caberá ao coordenador da configuração inserir todos estes arquivos no repositório. $\hat{\mathrm{E}}$ preciso que se decida entäo como sera comunicado ao coordenador da configuração que existem arquivos disponiveis para inserçāo no repositório. Uma opçāo seria realizar esta comuricaçāo através de uma mensagem por e-mail ou de uma consulta periódica a um local previamente cstabelecido para armazenamento dos componentes, e sua respectiva documentaçāo, a serem inseridos na ferramenta de controle de versöes.

Os desenvolvedores devem possuir apenas direito de leitura no repositório de componentes, não estando autorizados a fazer qualquer tipo de atualização do mesmo. Desta maneira, estes somente poderiam fazer o check out dos itens da 
configuraçāo, cuja intenção deverá scr a obtenção do componente para reuiso ou para estudo, mas jamais para alteração.

$\Lambda$ retirada de componentes com o objetivo de alterá-los deverá poder ser feita somente para componentes com status AP - Aprovado mediante autorizaçáo do coordenador da configuração. Assim, frente à necessidade de alteraçào de um ilem da configuraçào pertencente ao tronco (ou seja. com status AP. disponivel para reúso). o desenvolvedor deve solicitar a modificaça através de um pedido de alteraçāo. Esta solicitaçāo dcve passar por uma avaliaçäo quanto a sua real necessidade c corretitude. Tal avaliação deve ser realizada pelo coordenador da configuraçò.

O pedido de alteraçāo podera conter uma ou mais alteraçōes referentes a um único componente. informaçóes referentes ao autor do pedido, data do pedido. o itcm que sc descja alterar e sua respectiva versão. a(s) alteração(ōes) que se deseja, seu(s) respectivo(s) motivo(s) e breve(s) descriçāo(ōes) do que será leito. Registrado um pedido de alteração para um componente, o mesmo deve ter seu status alterado para PA - Com Pedido de Alteraçāo Solicitado.

Após a avaliacäo de um pedido. o desenvolvedor devera ser notilicado do seu resultado sendo que. em casos de negação deste pedido, está notificaçăo deve ser acompanhada de uma justificativa.

No caso de pedidos reprovados. o status do componente deve ser alterado para AP - Aprovado.

Para os pedidos aprovados, o stalus do componente deve ser alterado para $A T$ - Em Alteração e o item da configuração correspondente ao componente a ser alterado deve ser bloqueado no repositório pelo coordenador da configuraçāo e disponibilizado ao descnvolvedor em uma área reservada ao mesmo. Em outras palavras, caberá ao coordenador da configuraçāo alterar o status do componente e cxccutar a operaçāo de check out com lock do itcm da configuracāo em um diretório especilicamente reservado para este fim. Ressalta-se que somente o autor do pedido de alteraçào deverá ter acesso a este diretorio. Sugere-se que este item seja bloqueado no repositório para que se garanta que somente um pedido de alteração está sendo atendido por vez. Desta maneira, nāo devem haver alteracòes simultàneas nos componentes c, conseqüentemente. nāo devem haver conflitos. Por medida de segurança, sugere-se também que exalamente antes de autorizar a alleração do componente, uma consulta ao status do mesmo no 
repositório (bloqueado ou liberado) seja realizada. O bloqueio deste componente deve obrigatoriamente ser feito assim que o pedido de alteraçāo for aprovado.

Após a alteração do item da configuração, este deve ser documentado c disponibilizado para revisão. Caso csta nova documcntaçāo seja aprovada, o item (acompanhado de sua documentação) deverá ser atualizado novamente no re positório (check in) pelo coordenador da configuração gerando assim uma nova versāo do item e liberando-o para novas alteraçōes. Caso aprovado provisoria mente, o componente deve ser atualizado como branch e a versāo do tronco deve permanccer bloqueada até que o mesmo seja aprovado sem restriçōes ou definitivamente reprovado. O número de versão associado ao componente deve ser atualizado na documentação externa antes de a mesma ser também inserida no repositorio de controle de versões. Desta maneira pretende-se manter consistentes a vcrsāo aprescntada na ferramenta c a versão mostrada na documentação. Algumas ferramentas disponibilizam a possibilidade de se gerar novas versöes de um arquivo mesmo que não existam diferenças entre a última versão e a atual. Recomenda-se fortemente que tal opçāo scja selecionada para todos os arquivos dos componentes (código-fonte e documentação externa) a fim de que sc mantcnha consistentes os seus números de versão.

Se o item da configuração alterado for reprovado na revisão, cabe ao coordenador da configuração associar a sua documentação o status RP - Reprovado c libcrar a sua versão bloqueada para novas alterações.

O processo de alteraçāo de itens de configuraçāo cstá ilustrado na Figura 8. 10

Toda a manutençào e integridade do repositório é responsabilidade do coordenador da configuraçào.

\subsection{Relato da Situação da Configuração}

Cabe ao coordenador da configuraçāo gerar os relatorios de configuração que forem necessários. Estes relatórios podem contcr novos componentes, componentes reprovados. solicitaçōes de alteração negadas, documentaçōes reprovadas, entre outras informaçōes.

Por ser extremamente dependente das particularidades e necessidades da organização, é de responsabilidade do grupo de trabalho definir que tipos de relatórios devem ser disponibilizados, quais informaçōes devem estar prescntes c para quem os mesmos podem ser disponibilizados. É bastante útil a existencia de 


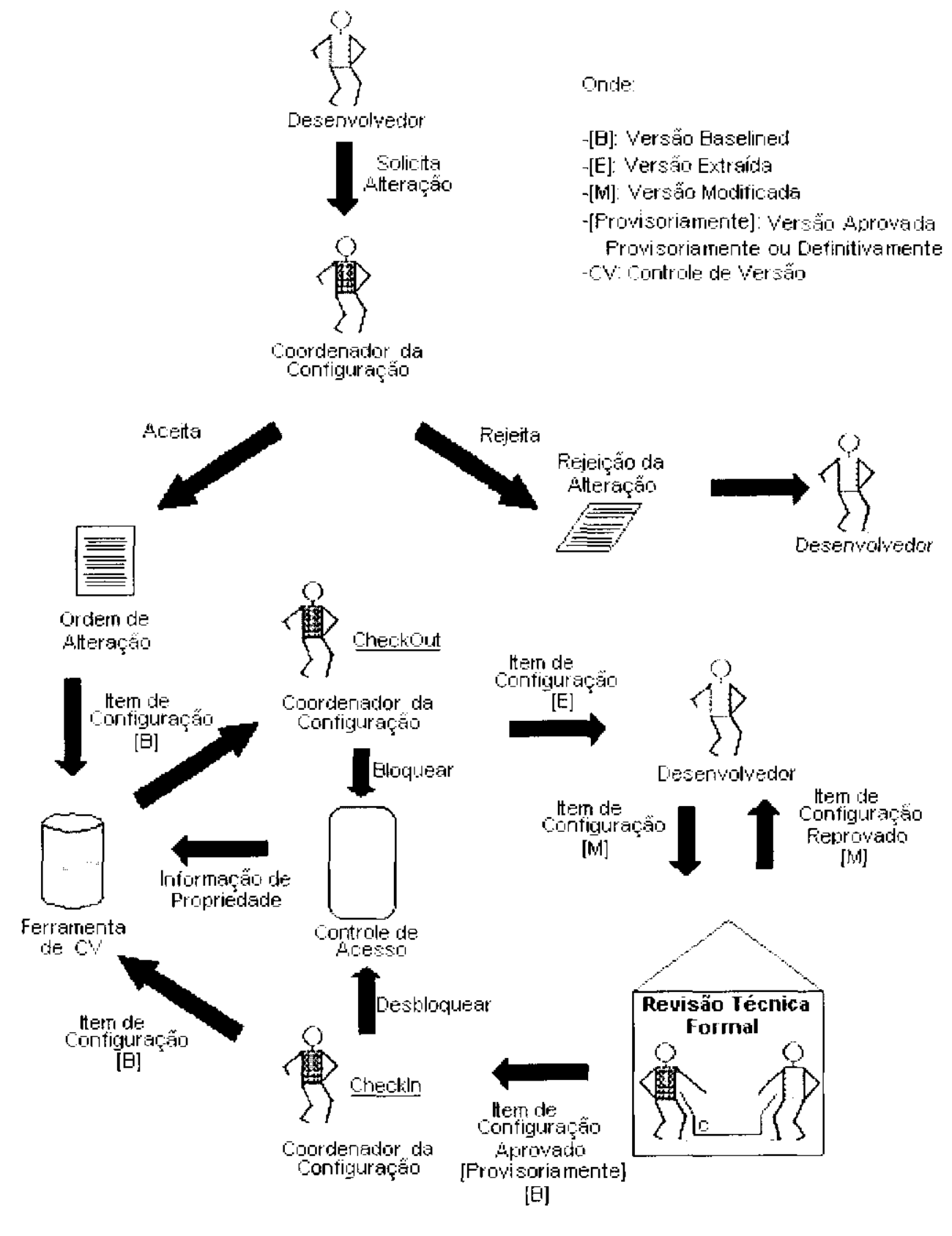

Figura 8.10: Processo de Alteração de um Item de Configuraçāo

rotinas para geração destes relatórios caso sua implementação seja possivel c viávcl.

\subsection{Auditoria da Configuração}

Por envolverem atividades complexas e dispendiosas de tempo, num primeiro momento nāo se sugerc a rcalização de auditorias de configuraçāo. Scndo assim. torna-se responsabilidade dos coordenadores de revisao c de configuração detectar problemas nos procedimentos e nos itens de configuraçăo durante as 
atividades de avaliação. Vale ressaltar quc os revisores deverão analisar, no caso de alteraçōes nos itens da configuraçāo, se a alteração rcalizada no item foi exatamente a alteração espccificada na solicitação de mudança. não podendo ser aceitas extensōes ou reduçōes na alteraçāo que foi aprovada.

\subsection{Controle de Interface}

Inicialmente, sugere-se que não seja realizado controle de interfacc, exceto em casos nos quais sua execução possa trazer beneficios consideráveis.

\subsection{Controle de Sub-contratados e Fornecedores}

Por se tratar de um plano de configuração para organizaçóes de pequeno porte. considcra-se que nāo existam sub-contratados e fornecedores e, portanto, este tópico nāo ć abordado neste plano. Para organizaçōes que nāo estejam de acordo com csta considcração, processos para controle do código produzido por subcontratados e fornecedores devem ser estabelecidos.

\section{Roteiro para Implantação do Gerenciamento de Configuração}

Neste item é abordada a implantação do gerenciamento de configuração, assim como a implantação da revisão técnica formal e dos padrôes de código e documentação, atividades essenciais ao gerenciamento de configuração tal como foi definido neste plano.

A implantaçāo de todas estas atividades deve seguir um roteiro previamente estabelecido. Em um primeiro momento, a organização deverá criar a infra-cstrutura nccessária e treinar alguns de scus descnvolvedorcs no uso desta infra-estrutura e dos processos definidos. I’osteriormentc, deverá ser execulado um projeto piloto afim de testar na prática o que foi teoricamente definido. Após a adaptação do proccsso com base nos resultados dos testes, os desenvolvedores devem ser treinados para suas funçōes, us componentes já existentes devem passar pelas revisōes c o rcpositório deve ser carregado com os componentes aprovados para então se adotar cfetivamente os novos padrōes e processos no dia-a-dia dos desenvolvedores.

O roteiro de implantação proposto envolve as seguintes atividades:

- Instalar todas as ferramentas necessárias;

- Testar o processo em um projeto piloto:

- Designar desenvolvedores para os cargos de coordenador da configuração e coordcnador da revisāo: 
- Designar alguns desenvolvedores (no mínimo dois) para serem revisores no projeto piloto:

- Escolher um conjunto pequeno, porém representativo, de componentes para serem utilizados no projeto piloto;

- Treinar os desenvolvedores, coordenadores e revisores selecionados no processo de revisão técnica formal a ser adotado, no processo de gerenciamento de configuracão. nos padrōes definidos c nas ferramentas a serem utilizadas:

- Exccutar os processos acima mencionados:

- Verificar os problemas encontrados:

- Adaptar os processos

- Designar desenvolvedores para os cargos de coordenador da configuração, coordenador da revisão e revisores, assim como suas respectivas área de atuaçao. Vale ressaltar que estes desenvolvedores podem ou não ser os mesmos utilizados no projeto piloto. Recomenda-se que. se os desenvolvedores utilizados tenham se adaptado bem às suas funcões, eles sejam mantidos para evitar novos esforcos de treinamento e adaptaçāo. Quanto ao grupo de revisores, este deve receber novos membros a fim de satisfazer as necessidades da organizaçāo:

- Treinar os coordenadores e revisores, caso necessário, no processo de revisão técnica formal a ser adotado, no processo de gerenciamento de configuraçăo. nos requisitos definidos e nas ferramentas utilizadas:

- Revisar os componentes já prontos e carregar o repositorio com os mesmos;

- Treinar os desenvolvedores no novo processo de desenvolvimento. agora considerando reuso de componentes, gerenciamento de configuraçāo. revisão técnica formal, padrões para código e documentação. e o uso do repositório de componentes. Este treinamento deve ser particionado por assunto, a fim de nāo causar grande impacto e tentar minimizar a rejeição aos mesmos:

- Treinar os desenvolvedores nas ferramentas a serem utilizadas:

- Liberar o repositório de componentes para uso.

\section{Recursos Necessários ao Processo de Gerenciamento de Configuração}

Os recursos necessários para a execuçāo do plano de gerenciamento de configuração são: 


\section{Pessoas:}

Coordenador da Configuraçāo: descnvolvedor responsável por coordenar o gerenciamento de configuraçāo.

Desenvolvedores: desenvolvedores da organização cujo trabalho envolve o reúso de componentes.

Devem também ser considerados os profissionais responsáveis pela execução das revisões (atividade essencial para o processo de gerenciamento de configuraçāo tal como proposto neste plano): revisores, lideres de revisão e coordenador de revisão.

\section{Equipamentos:}

Devem ser especificados os equipamentos necessários para a utilizaçāo deste processo de gerenciamento de configuraçāo. Por ser muito particular, dependente das ferramentas a serem utilizadas, este item nāo será detalhado.

\section{Ferramentas:}

Neste item devem ser especificadas as ferramentas a serem utilizadas pclo grupo. Mais uma vez, em virtude da sua natureza particular, este item não será detalhado. Porèm, ao menos um ponto pode ser ressaltado: a necessidade de uma ferramenta para controle de versões.

Sugere-se o uso do Concurrent Versions System (CVS), selecionado durante o estudo de caso. para este fim.

Vale ressaltar que a ferramenta a ser utilizada para controle de versōes poderá exigir a cxecuçāo de algumas alividades extras por parte do coordenador da configuração. Este tipo de responsabilidade precisa ser identificada e especificada no plano de gerenciamento de configuraçào. exigindo, conseqüentemente, que a ferramenta a ser utilizada já esteja também definida. Por exemplo, a ferramenta CVS (Cederqvist. Grubbs, Brunskill. Dyer, Pingle, Peterson. Wallin. Koschuelzki. \& Brown 1992) exige a alteração de arquivos administrativos para registrar a criação dos módulos. Caberia entāo ao coordenador da configuração alterar este arquivo a fim de registrar a criaçāo dos módulos que reflitam a classificaçāo hicrárquica do repositório e a criação dos módulus para cada componente. Neste caso, esta funçāo deveria estar especificada no plano de gerenciamento de configuraçāo.

\section{Manutenção}


O plano de gerenciamento de configuraçāo de software deve refletir a forma como o gerenciamento de configuraçào está sendo aplicado. Espera-se que a mancira como as tarefas de gerenciamento de configuração de sofiware são executadas seja allcrada com o decorrer do tempo. Assim. é necessário que o plano de gerenciancnto de configuraçāo seja at ualizado continuamente para que reflita as mudanças implantadas. Essta tarefa cabe ao coordenador de configuração de software, responsável também por decidir quando um determinado ponto do plano deve ser alterado. Dessa maneira, cabe ao coordenador da configuraçāo identificar pontos de melhoria, testar a mudança, alterar o plano de gerenciamento de configuraçào e implantá-la. Vale ressaltar que a alteraçāo no plano deve, obrigatoriamente, ser informada a todas as pessoas envolvidas.

\subsection{Considerações Finais}

Neste capitulo foi apresentada uma estratégia para definiçāo e implantação gradativa das atividades e requisitos necessários a um processo de desenvolvimento de software baseado no reuso de componentes.

No cntanto, para garantir a efetividade de tais atividades e a consistência das informações, um grande esforço de coordenação e gerenciamento deve ser realizado. Certamente, enquanto manual, este esforco está sujeito a falhas. Com o intuito de tentar reduzir esta vulnerabilidade, é proposto um ambiente para automatizar algumas das atividades referentes ao gerenciamento dos componentes - o RaCooMN (Reusable Components Management ENvironment). A especificação desse ambiente é apresentada no capitulo a seguir. 


\section{Capítulo 9}

\section{RaCooMN - Reusable Components Management ENvironment}

\subsection{Considerações Iniciais}

Certamente, o controle e excução manual de todas as atividades referentes ao gerenciamento dos componentes propostas no capitulo anterior é oneroso e passivel de crros ou inconsistências. Assim. nesta seção é descrita a especificação de um ambiente, denominado RaCooMN - Reusable Components Management ENvironment, que auxilia na execução das atividades inicialmente definidas como prioritárias para a introduçao do reuso no processo de desenvolvimento de software de uma organizaçăo: documentação. verificaçào e gerenciamento de configuração.

\subsection{O Processo de Especificação do Ambiente RaCooMN}

Colanzi (1999) apresenta um processo de desenvolvimento de software denominado ProDes/UML (Processo de Desenvolvimento de Softuare para UML). Este processo não possui notação propria. utilizando a UML ${ }^{1}$ (Unified Modeling language) (Fowler \& Scott 1997: Fowler \& Scott 2000; OMG 2001; Rumbaugh, Jacobson, \& Booch 1999) para representar seus diagramas.

O ProDes/UML ć composto por quatro fases: Engenharia de Requisitos, Análise, Projeto c Implementação. A atividade de teste é iniciada na fase de cngenharia de requisitos c

'Segundo o Object Management Group (OMG 2001) a UML e "uma linguagem para especilicaçāo, visualizaçào, construçáo e documentaçào de artefatos de sistemas de soffuare. assim como modelaźrem de negúcio e. out ros sistenlas nào-softuare." 
estende-se por todo o processo. Cada uma das fases é descrita, de mancira sucinta, a seguir:

Engenharia de Requisitos São elicitados os requisitos do sistema $\mathrm{cm}$ tcrmos de casos de uso;

Análise É especificado o comportamento esperado do sistema através da definição da interface entrc o mesmo c o ambiente, ou seja, as operaçôes que podem ser executadas:

Projeto Ê espccificado como as funcionalidades do sistema serão implementadas por intermédio da interação de vários objetos;

Implementação Consiste basicamente na tradução do que foi projetado para uma linguagem de programação. Mudanças no projeto podem ser necessárias em função de problemas que tenham sido descobertos nesta fase.

Na Tabela 9.1 é apresentada a relação cntre os diagramas produzidos nas fases do ProDes/UML e os diagramas UML.

\begin{tabular}{|c|c|c|}
\hline Fase & Diagramas do ProDes/UML & Diagramas da UML \\
\hline $\begin{array}{l}\text { Engenharia } \\
\text { de Requisitos }\end{array}$ & $\begin{array}{l}\text { Diagrama de Casos de Uso } \\
\text { Especificação de Casos de Uso } \\
\text { Diagrama de Classes do Dominio }\end{array}$ & $\begin{array}{l}\text { Diagrama de Casos de Uso } \\
\text { Diagrama de Classes }\end{array}$ \\
\hline Análise & $\begin{array}{l}\text { Diagrama de Classes de Análise } \\
\text { Cenários } \\
\text { Modelo de Operaçóes } \\
\text { Modelo de Ciclo de Vida }\end{array}$ & $\begin{array}{l}\text { Diagrama de Classes } \\
\text { Diagramas de Seqüencia } \\
\text { Diagramas de Estado }\end{array}$ \\
\hline Projeto & $\begin{array}{l}\text { Diagrama de Colaboração } \\
\text { Diagrama de Visibilidade } \\
\text { Diagramas de Classes da Análise Refinado } \\
\text { Descrição das Classes } \\
\text { Diagramas de Estado das Classes }\end{array}$ & $\begin{array}{l}\text { Diagrama de Colaboração } \\
\text { Diagramas de Classes } \\
\text { Diagramas de Classes } \\
\text { Diagramas de Estado }\end{array}$ \\
\hline
\end{tabular}

Tabcla 9.1: Correspondència entre os Diagramas das Fases do ProDes/UML c os Diagramas da UML

Neste trabalho. apenas a fase de engenharia de requisitos foi contemplada com vistas a especificaçāo do ambiente RaCooMN, apresentada na Seçāo 9.3. 


\subsection{RaCooMN - Fase de Engenharia de Requisitos}

Como já foi apresentado anteriorment e. o RaCooMN - Reusable Components Management ENvironment é um ambiente que auxilia a execuçāo das atividades inicialmente definidas como prioritárias para a introdução do reúso no processo de desenvolvimento de softuvare de uma organização: documentaçào, verificação e gerenciamento de configuraçào.

Nesta seçào, a fase de engenharia de requisitos proposta pelo ProDes/UML sera instan ciada com as informaçoes do ambiente RaCoomN. Mais especificamente, esta fase pode ser decomposta con duas perspectivas:

- Funcional: descreve as funcionalidades, os requisitos do ambiente. Para captura e. entendimento de lais requisitos, a técnica utilizada envolve a criação de casos de uso e especificacoes dos mesmos:

- Estrutural: constrói-se um modelo estático do dominio do problema abordado. O diagrama de classes do dominio é a visāo grálica utilizada no para representar tal perspectiva

Nas Scções 9.3.1 e 9.3.2, os produtos das perspectivas funcional e estrutural, instanci ados para o ambiente RaCoomN, são apresentados.

\subsubsection{Diagramas e Especificaçōes de Casos de Uso}

Como já foi citado anteriormente. dois dos produtos da fase de engenharia de requisitos são os casos de uso e suas respectivas especificaçóes. Os diversos casos de uso podem ser estruturados graficamente em diagramas de casos de uso. Tais diagramas têm como elementos principais os atores. os casos de uso e os relacionamentos existentes entre eles. Um ator é uma cntidade externa que interage com o ambiente, tal como um usuário ou um outro software. O caso de uso representa uma funcionalidade do sistema ou de um classificador, tal como um sub-sistema ou classe, c as relaçoes a ele manifestadas [Colanzi 1999; OMG 2001). Quanto a especificação, não existe um um formato rigido para sua estrutura.

Neste trabalho. diversos casos de uso foram especificados. Entre as funçōes mais importantes neles descritas estão:

- Busca de componentes;

- Obtença da documentação de lum componente; 
- Registro de componentes do tipo "em Desenvolvimento". Esta atividade é proposta com o objctivo comunicar aos desenvolvedores qual a funcionalidade dos componeutes que estāo em desenvolvimento. já que, pclo que foi proposto no capítulo anterior. somente os componentes que estảo prontos sāo armazenados no repositório de controle de versóes. Desta maneira espera-se que não sejam descnvolvidos componentes com a mesma funcionalidade desnecessariamente. Propōe-se entāo que, ao iniciar o desenvolvimento de um componente. o usuário cadastré-o no ambiente com algumas informaçōes básicas como. por exemplo, nome e funcionalidade. Tais componentes não serão armazenados no repositório da ferramenta de controle de versóes e poderão ainda ter o seu desenvolvimento cancelado. Mais detalhes sobre tais componentes podem ser obtidos nas especificações dos casos de uso;

- Registro de novos componentes;

- Cadastro do resultado de uma revisão de um componente;

- Inserçào de um componente aprovado ou aprovado provisoriamente no CVS;

- Solicitação de pedido de alteração:

- Cadastro do resultado da avaliaçāo de um pedido de alteração de um componente;

- Disponibilizar um componente para alteração;

- Documentação de alterações em um componente.

Interagindo com os casos de uso aparecem os seguintes atores:

- A_CMCoordinator: Coordenador do Gerenciamento de Configuração;

- A_CVS: Concurrent Versions System;

- $\Lambda$ Reviewer: Revisor;

- A_RevisionCoordinator: Coordenador de Revisão:

- A_RevisionLeader: Líder da Revisāo;

- A_User: Usuário.

Quanto às especificaçōes dos casos de uso, como jả foi citado anteriormente, não existe um padrāo definido pela UML para sua construçāo. Porém, é importante que ela seja 
padronizada c organizada, alem de possuir um nivel de detalhes suficiente para o entendimento das atividades descritas. Desta maneira, neste trabalho, a especificação dos casos de uso foram estruturadas de acordo com o template apresentado na labela 9.2 .

Um outro requisito que deve ser considerado diz respeito a acessibilidade e indepen déncia de plataforma do ambiente. sendo bastante interessante que nāo existam restriçócs referentes localização física dos usuatrios ou ao tipo de tecnologia por eles adotada. Deste modo, este ambiente deve ser implementado de maneira a ter sua interface disponibilizada na World Wide Web (WWW).

Os diagramas e as especificaçōes dos casos de uso construidos a partir dos requisitos do ambiente RaCooMN săo apresentados a seguir.

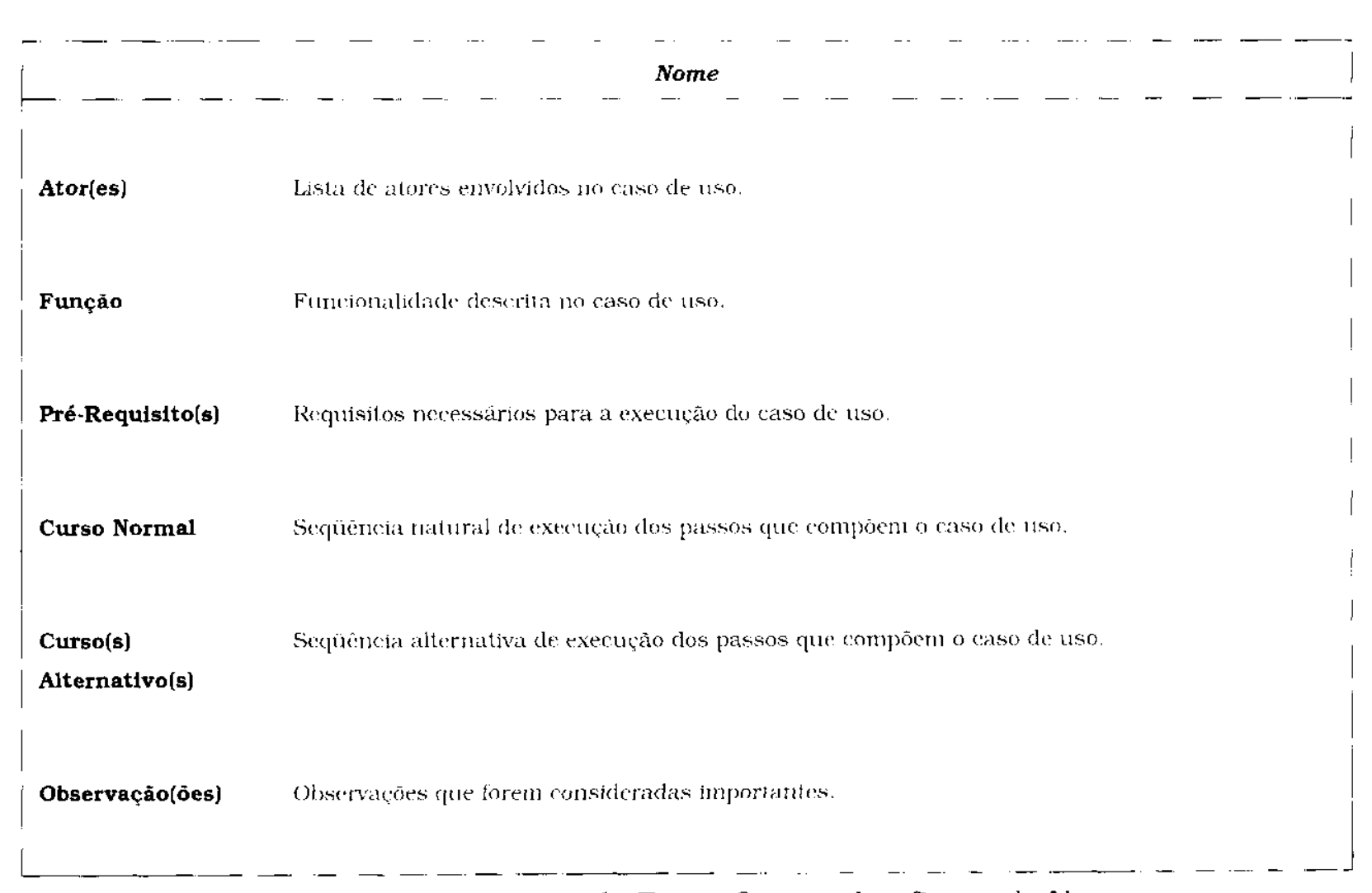

Tabcla 9.2: Estrutura da Especificaçāo dos Casos de Uso

\section{Caso de Uso - Cadastro de Usuário}

Neste caso de uso, cujo diagrama e especificação são apresentados, respectivamente, na Figura 9.1 e na Tabola 9.3 , é descrita a atividade de cadastro de um usuário. 


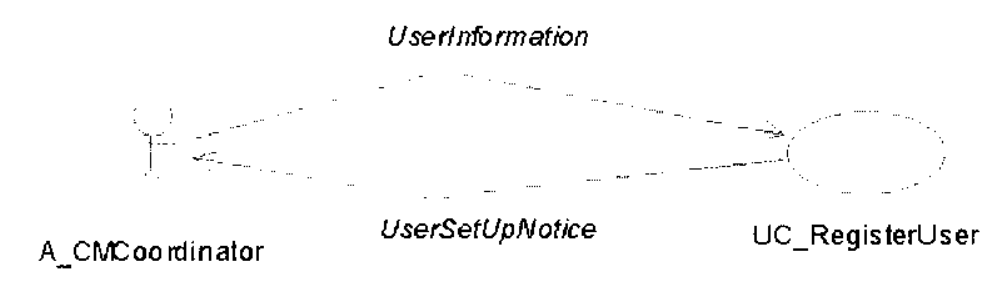

Figura 9.1: Diagrama de Caso de Uso - Cadastro de Usuário

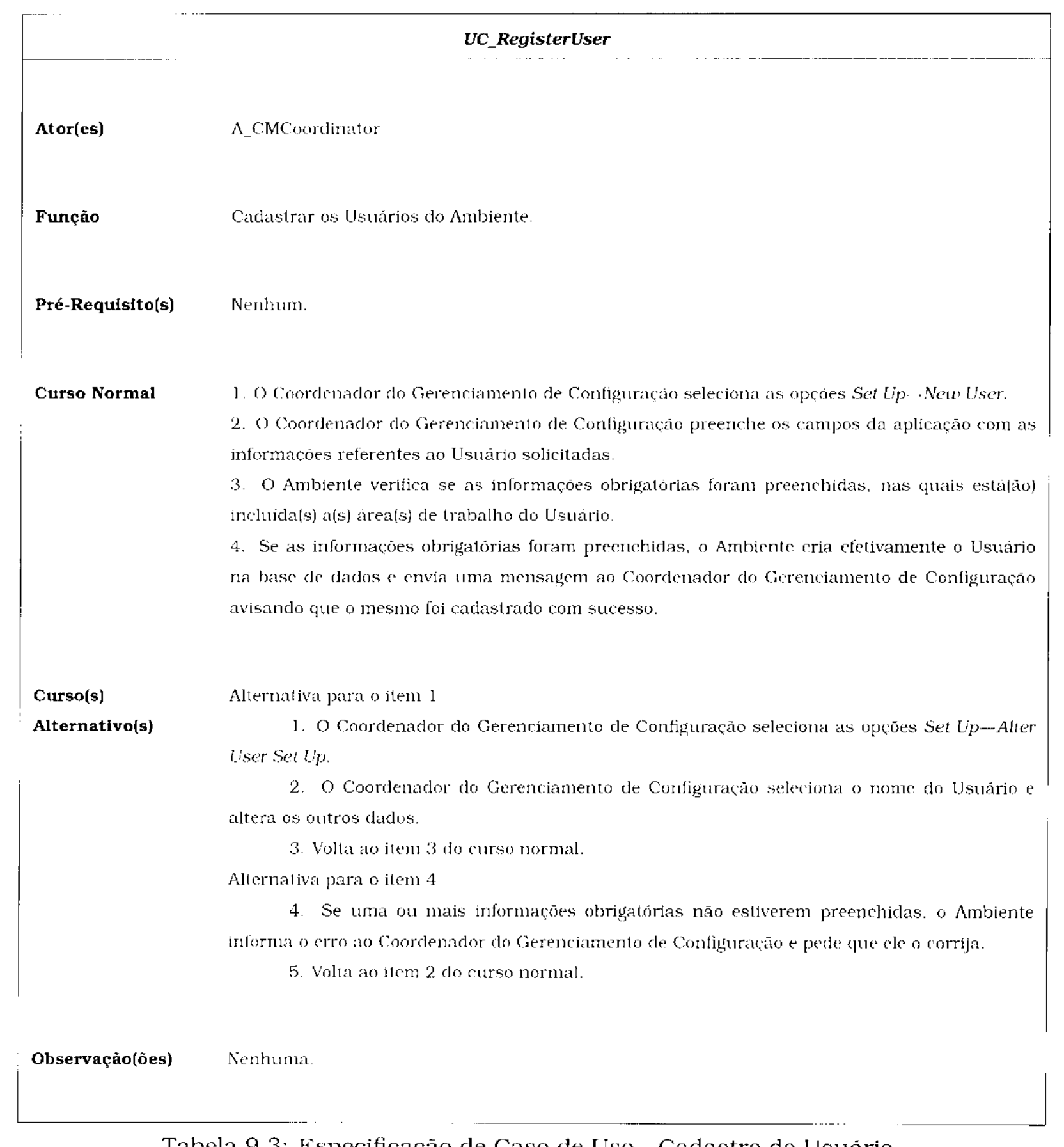

Tabela 9.3: Especificação de Caso de Uso - Cadastro de Usuário 


\section{Caso de Uso - Cadastro de Área de Trabaho}

Neste caso de uso. cujo diagrama e especificação são apresentados, respectivamente na Figura 9.2 e na Tabela 9.4, ć descrita a atividade de cadastro das possiveis áreas de trabalho.

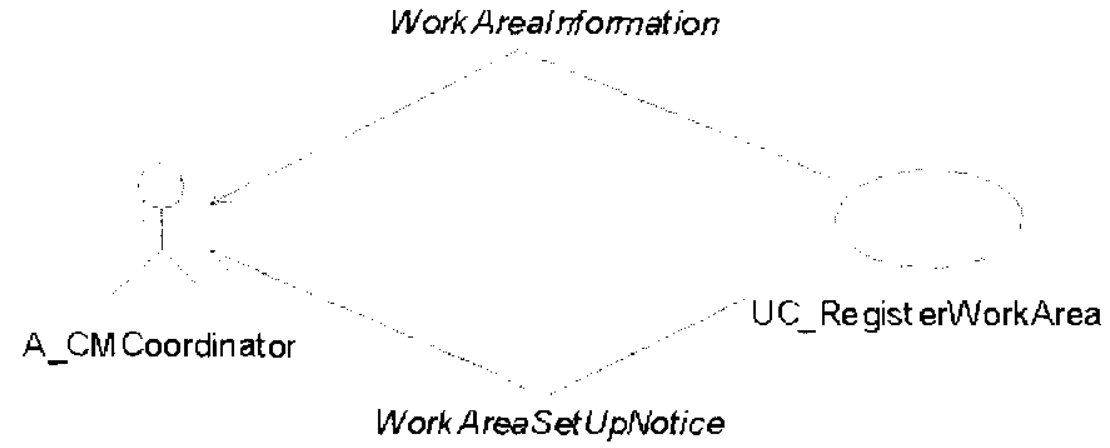

Figura 9.2: Diagrama de Caso de Uso - Cadastro de Área de Trabalho

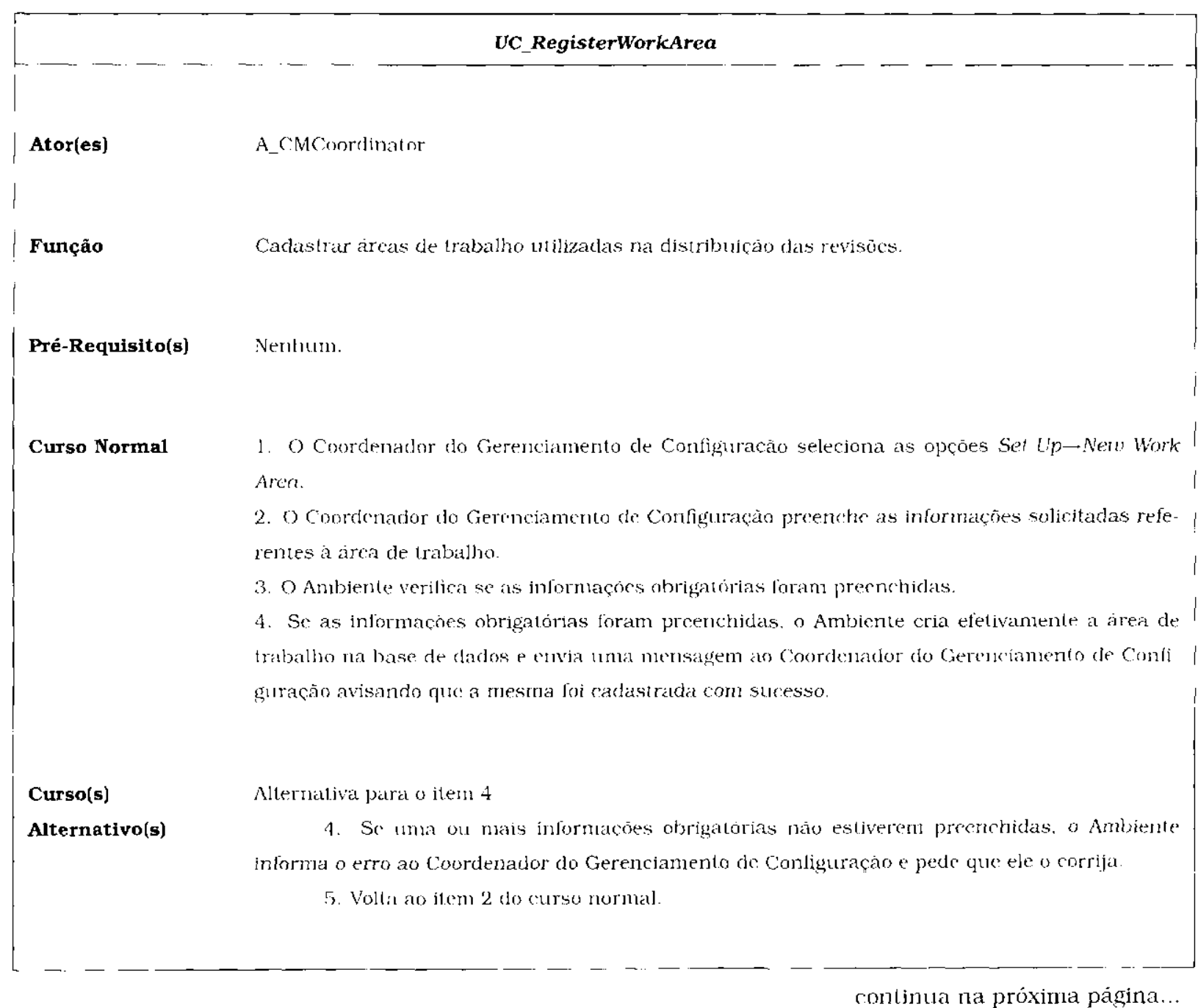




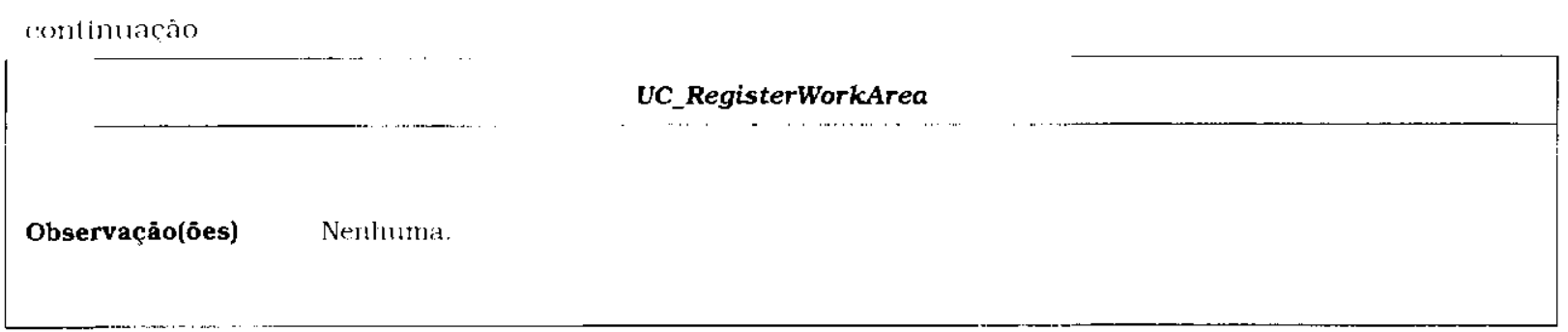

Tabela 9.4: Especificação de Caso de Uso - Cadastro de Área de Trabalho

\section{Caso de Uso - Conexão ao Ambiente}

Neste caso de uso, cujo diagrama e especificação são apresentados, respectivamente, na Figura 9.3 c na Tabela 9.5, e descrita a atividade de conexão ao ambiente.

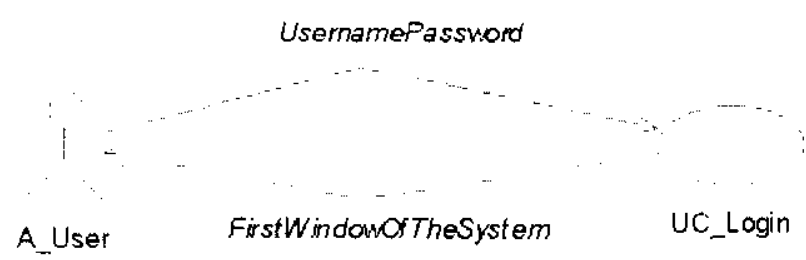

Figura 9.3: Diagrama de Caso de Uso - Conexão ao Ambiente

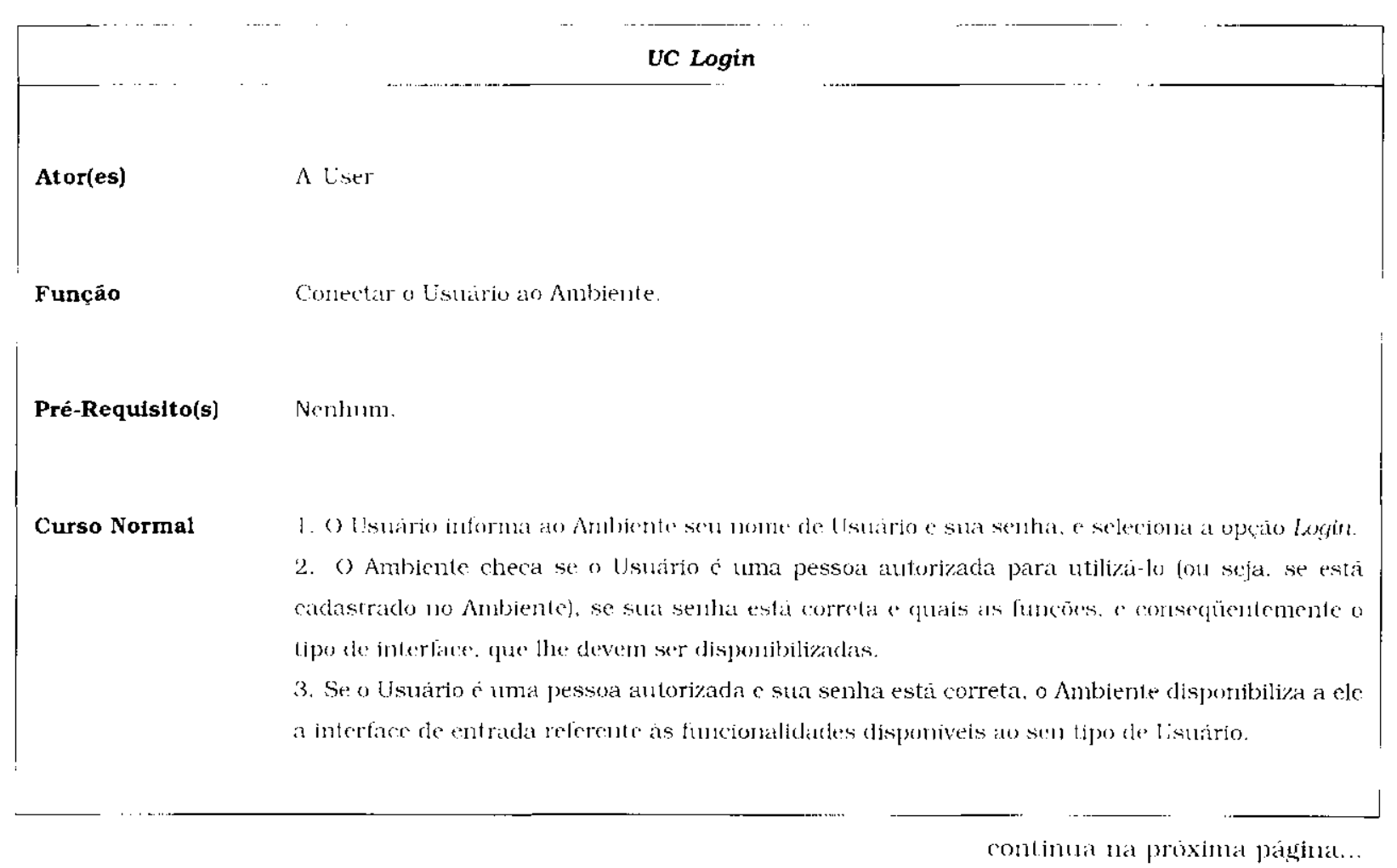




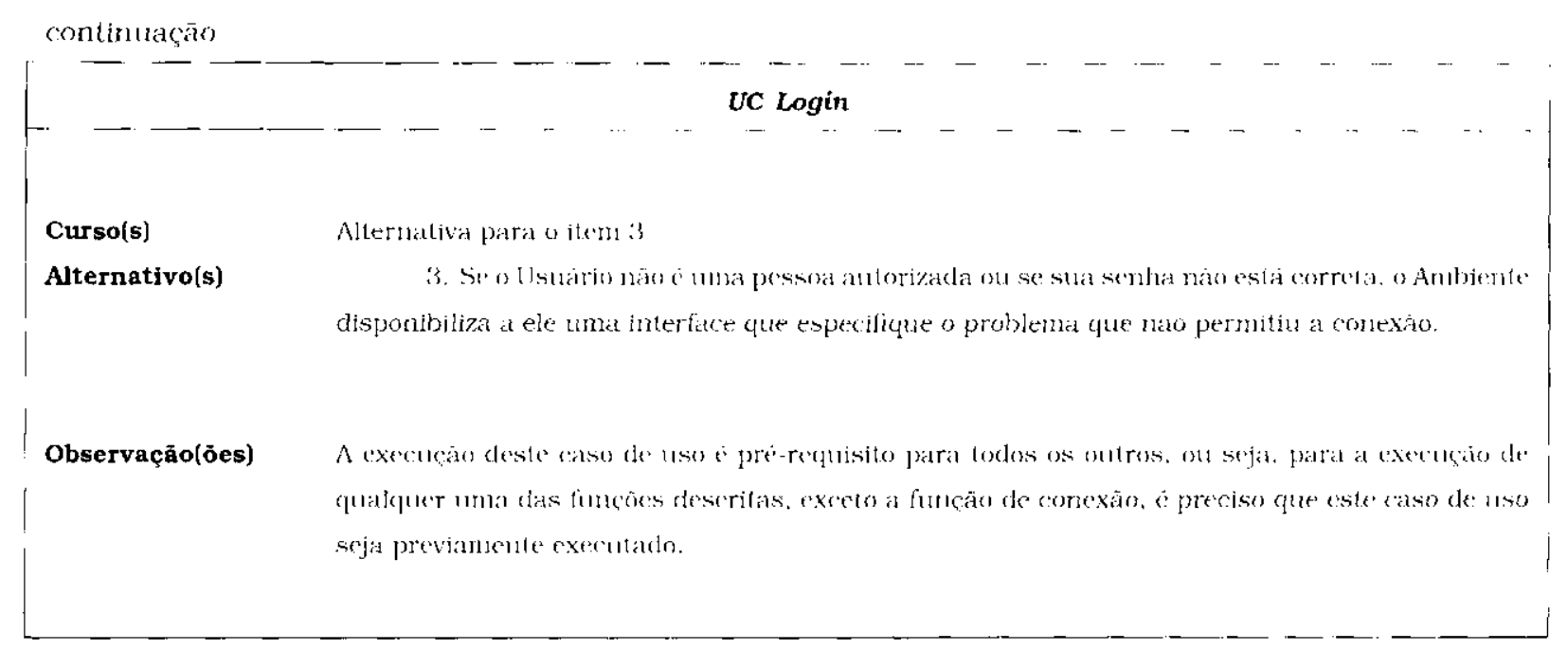

Tabela 9.5: Especificação de Caso de Uso - Concxão ao Ambiente

\section{Caso de Uso - Desconexão do Ambiente}

Neste caso de uso. cujo diagrama c especiticação são apresentados, respectivamente, na Figura 9.4 e na Tabela 9.6. é descrila a atividade de desconexão de um usuário do ambiente.

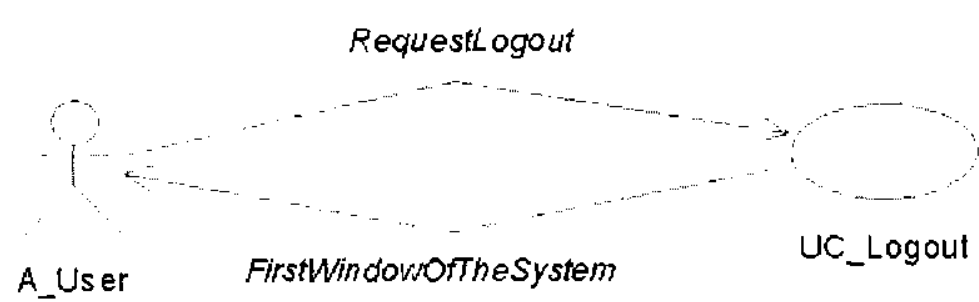

Figura 9.4: Diagrama de Caso de Uso - Desconexão do Ambiente

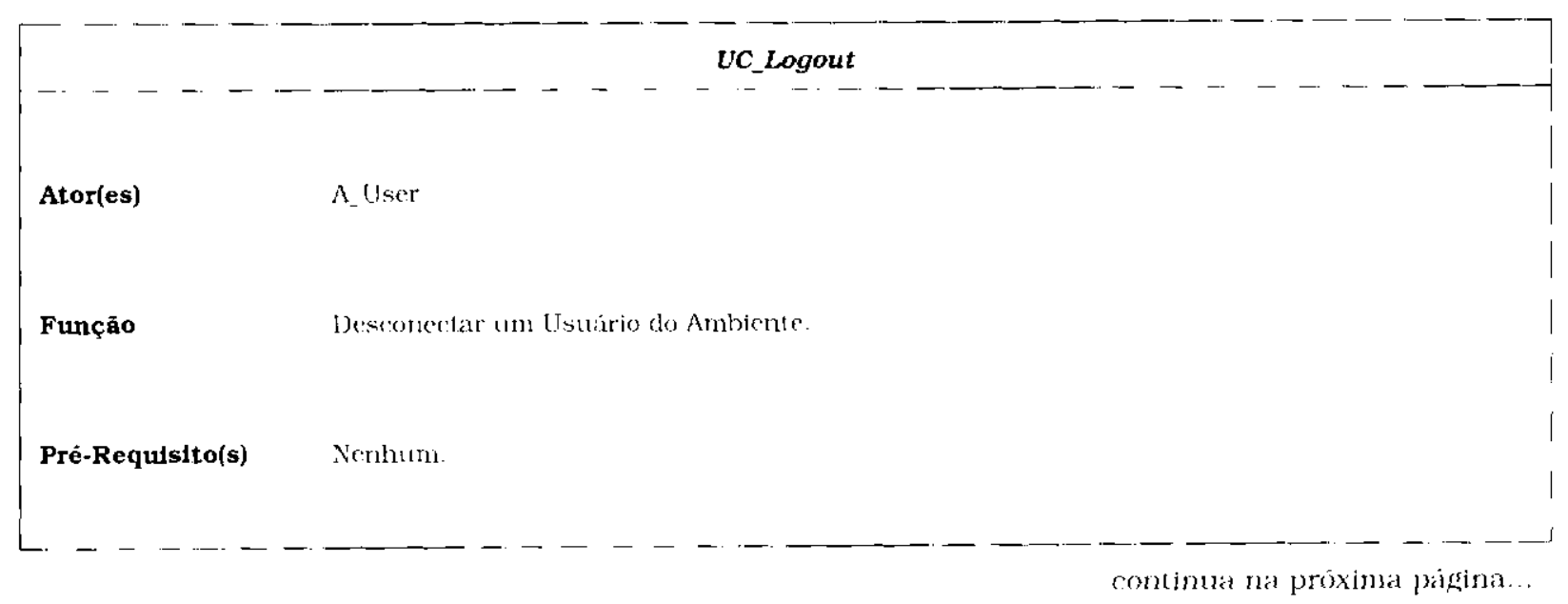




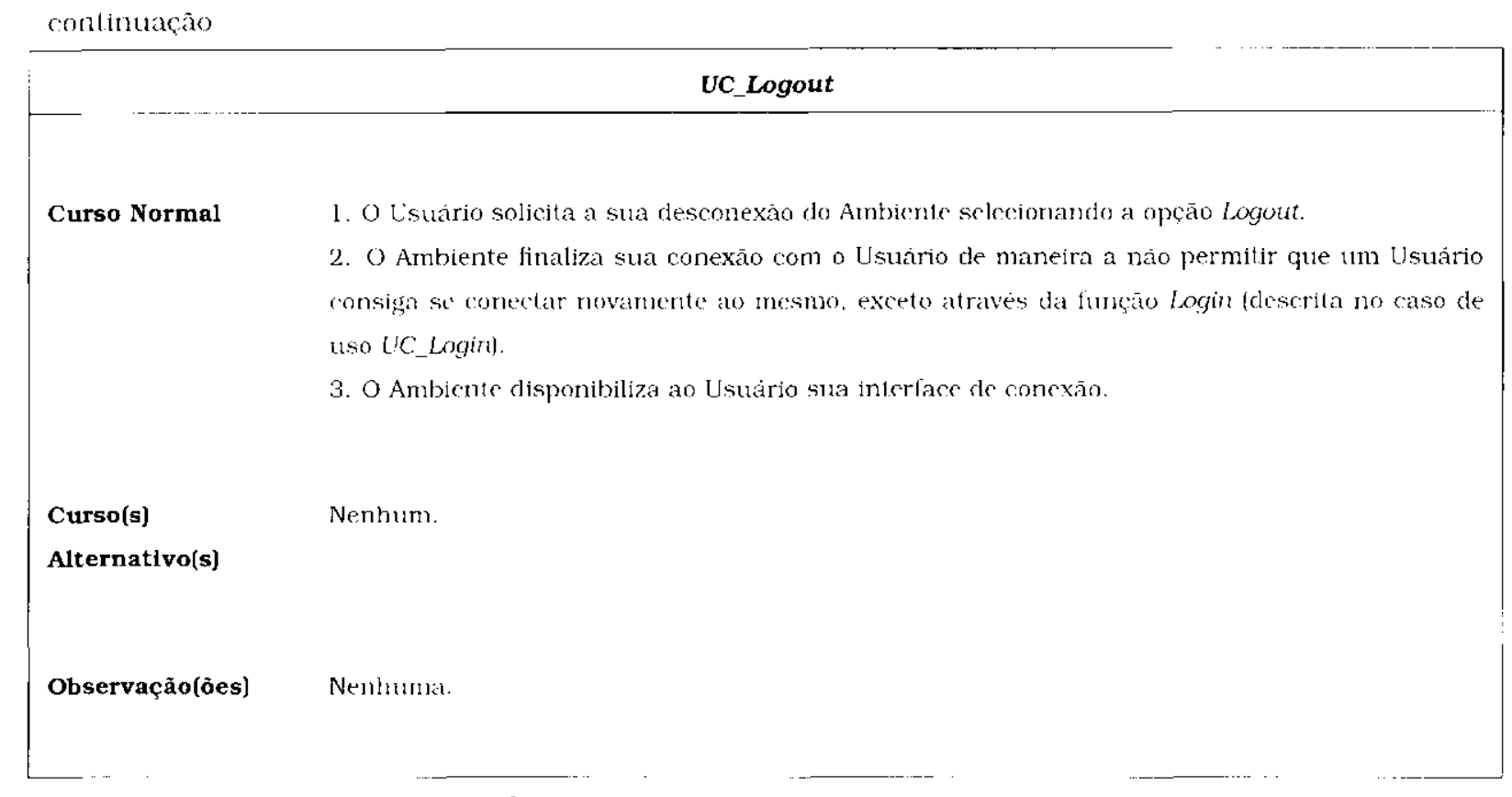

Tabela 9.6: Especificação de Caso de Uso - Desconexāo do Ambiente

\section{Caso de Uso - Busca de Componentes}

Neste caso de uso, cujo diagrama c especificaçào são apresentados. respectivamente, na Figura 9.5 e na Tabela 9.7. é descrita a atividade de busca por componentes que satisfaçam determinadas condicoes.

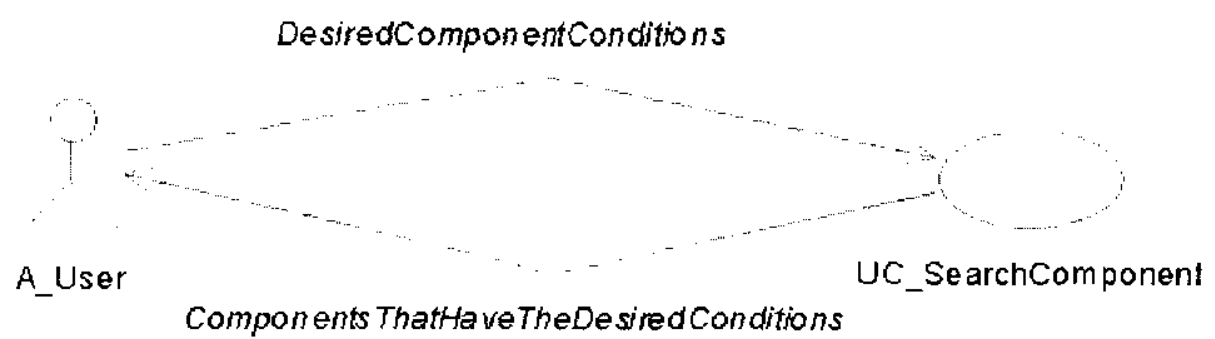

Figura 9.5: Diagrama de Caso de Uso - Busca de Componentes

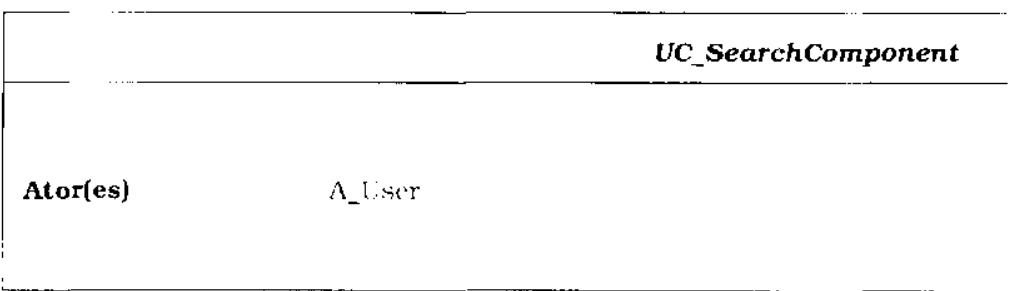

continua na proxima página... 


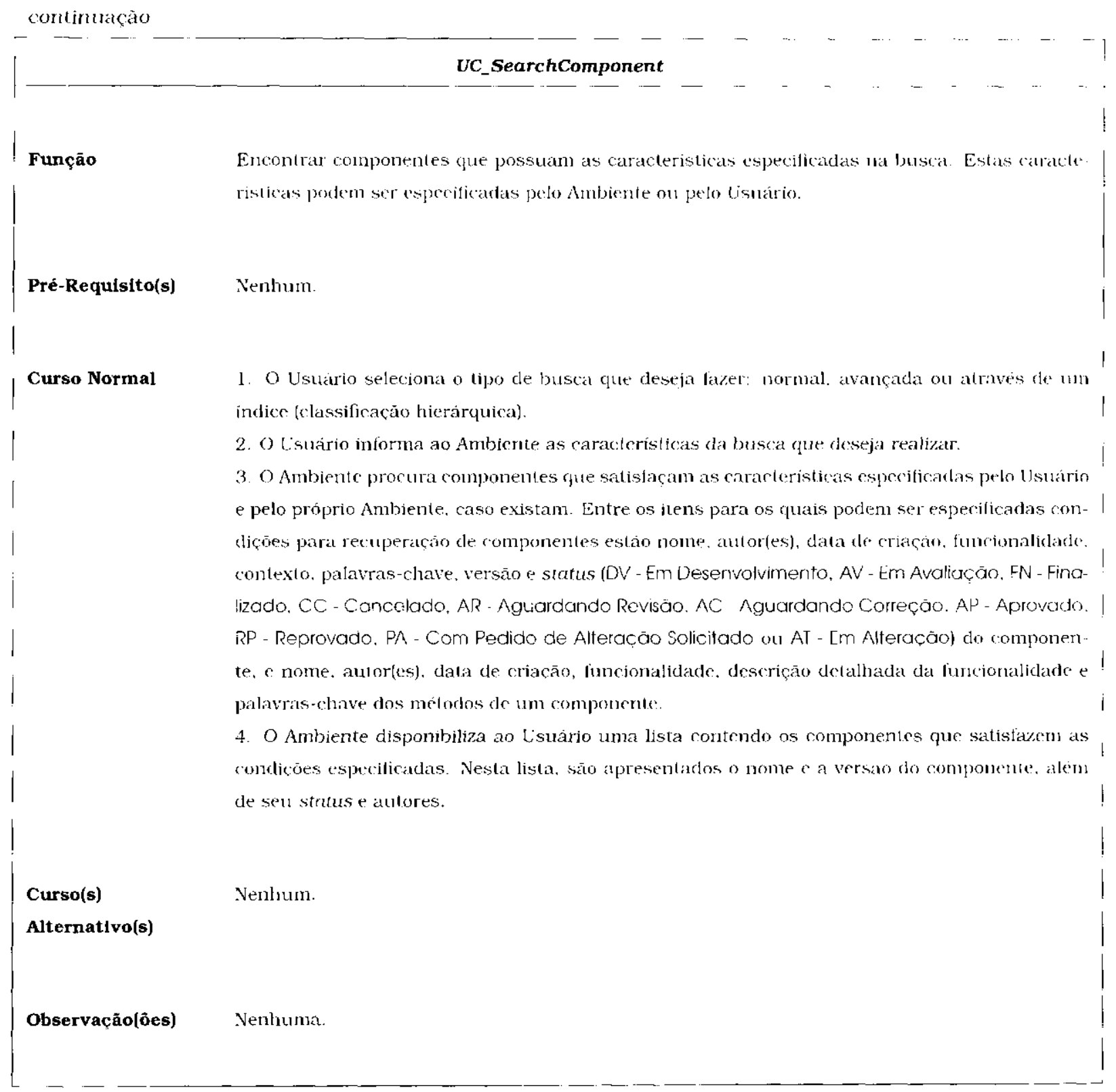

Tabcla 9.7: Especificação de Caso de Uso - Busca de Componentes

Caso de Uso - Visualização da Documentação de um Componente e Obtenção dos seus Arquivos no Concurrent Versions System (CVS)

Neste caso de uso. cujo diagrama e especificações são apresentados, respectivanentc, na Figura 9.6 c nas Tabelas 9.8. 9.9 e 9.7, são descritas as atividades de visualização. em sua interfacc, da documentaçāo de um determinado componente e obtençào dos scus arquivos (código-fonte c documentação cxterna) na ferramenta de controle de versāo (CVS). 


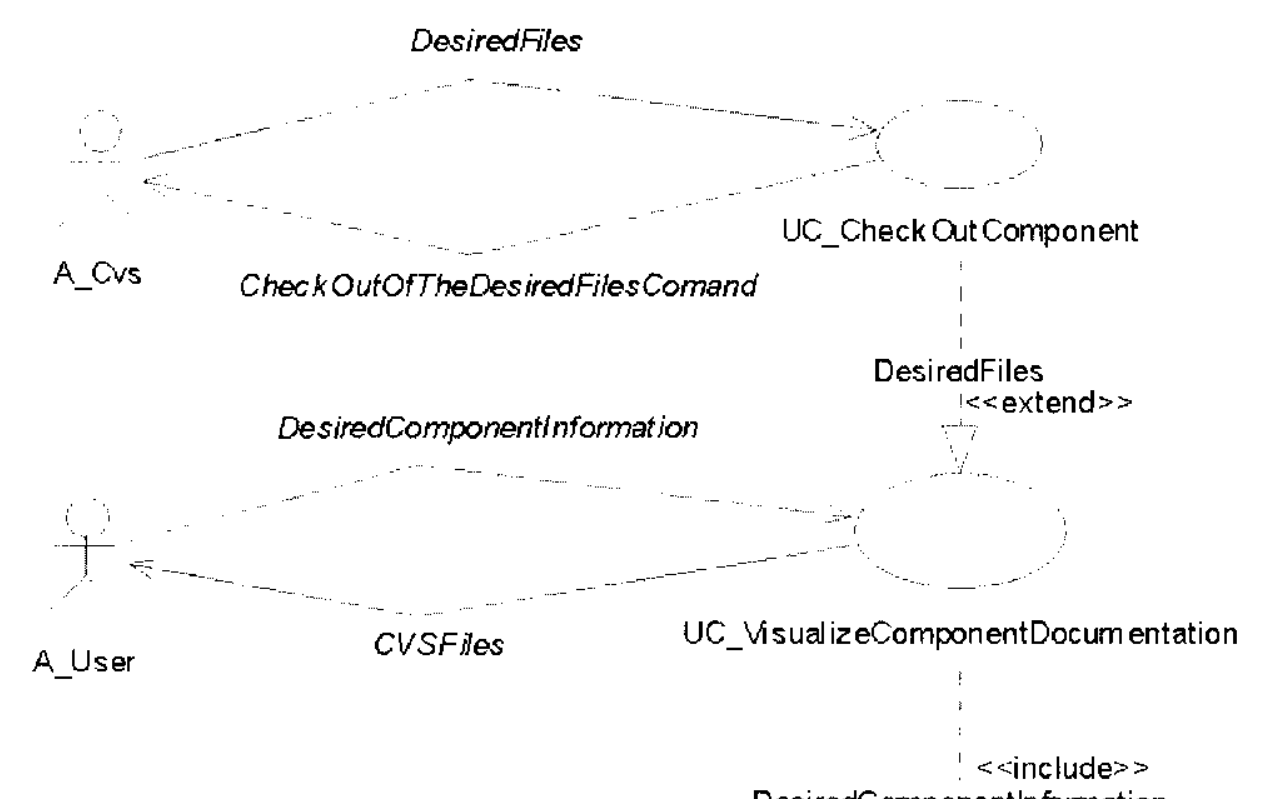

DesiredComponent Information

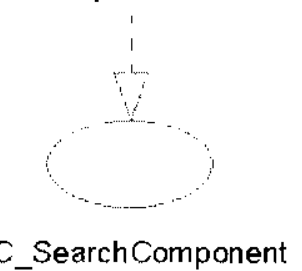

Figura 9.6: Diagrama de Caso de Uso - Visualizaçāo c Obtençāo da Documentaçāo de um Componente

\begin{tabular}{|c|c|}
\hline & UC_VisualizeComponentDocumentation \\
\hline Ator(es) & A_l $/ \mathrm{ser}$ \\
\hline Função & $\begin{array}{l}\text { Obter a documentacano do componente desciado, incluindo os arrpuvos do componente armizt } \\
\text { nados na terramenta cVs. }\end{array}$ \\
\hline Pré-Requisito(s) & Venhuma. \\
\hline Curso Normal & 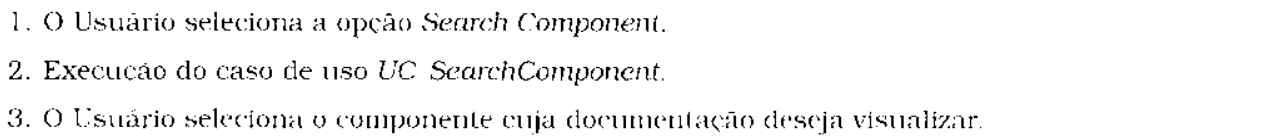 \\
\hline
\end{tabular}

continua na próxima página... 


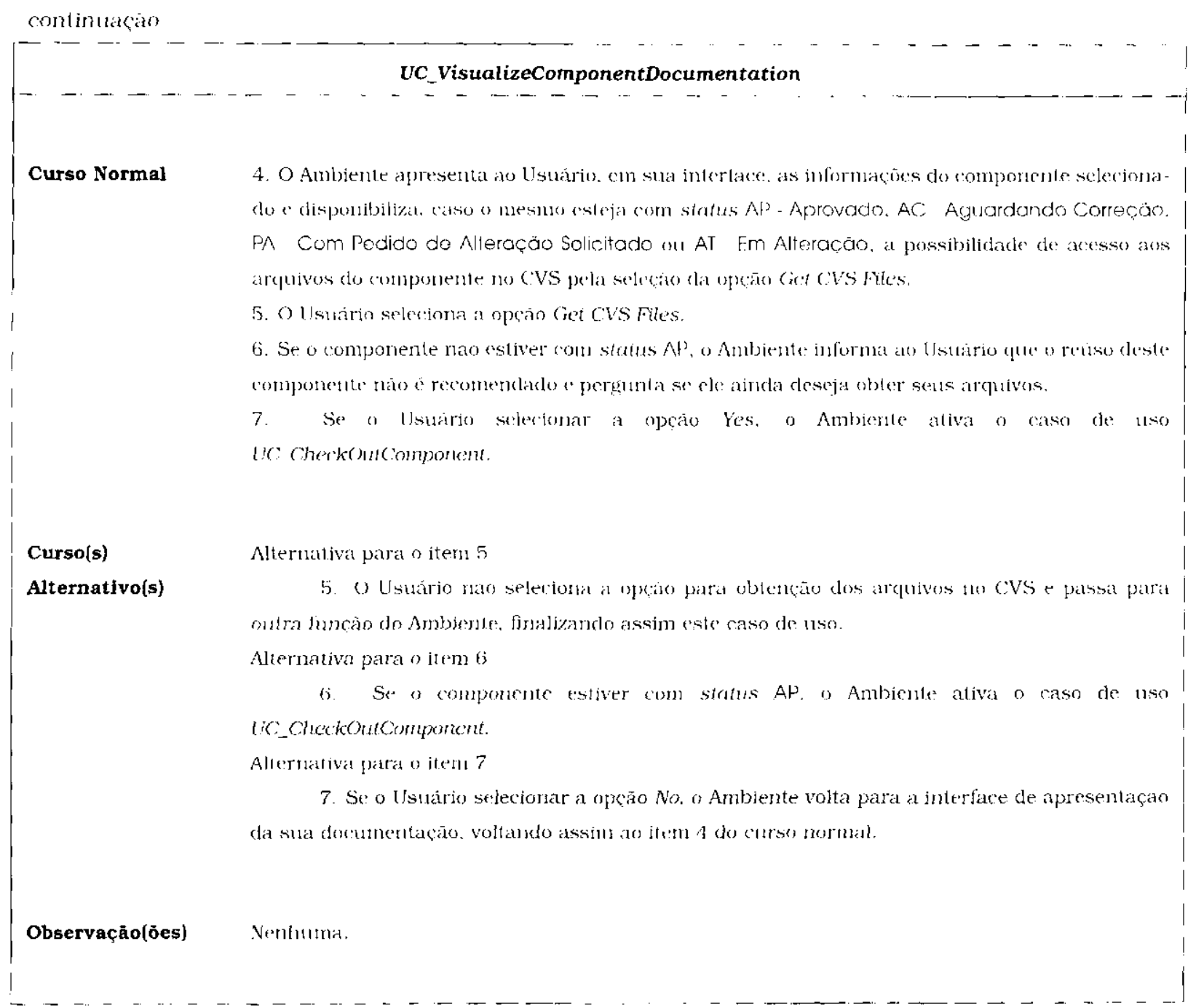

Tabela 9.8: Especificação de Caso de Uso - Visualizaçāo da Documentaçāo de um Com ponente

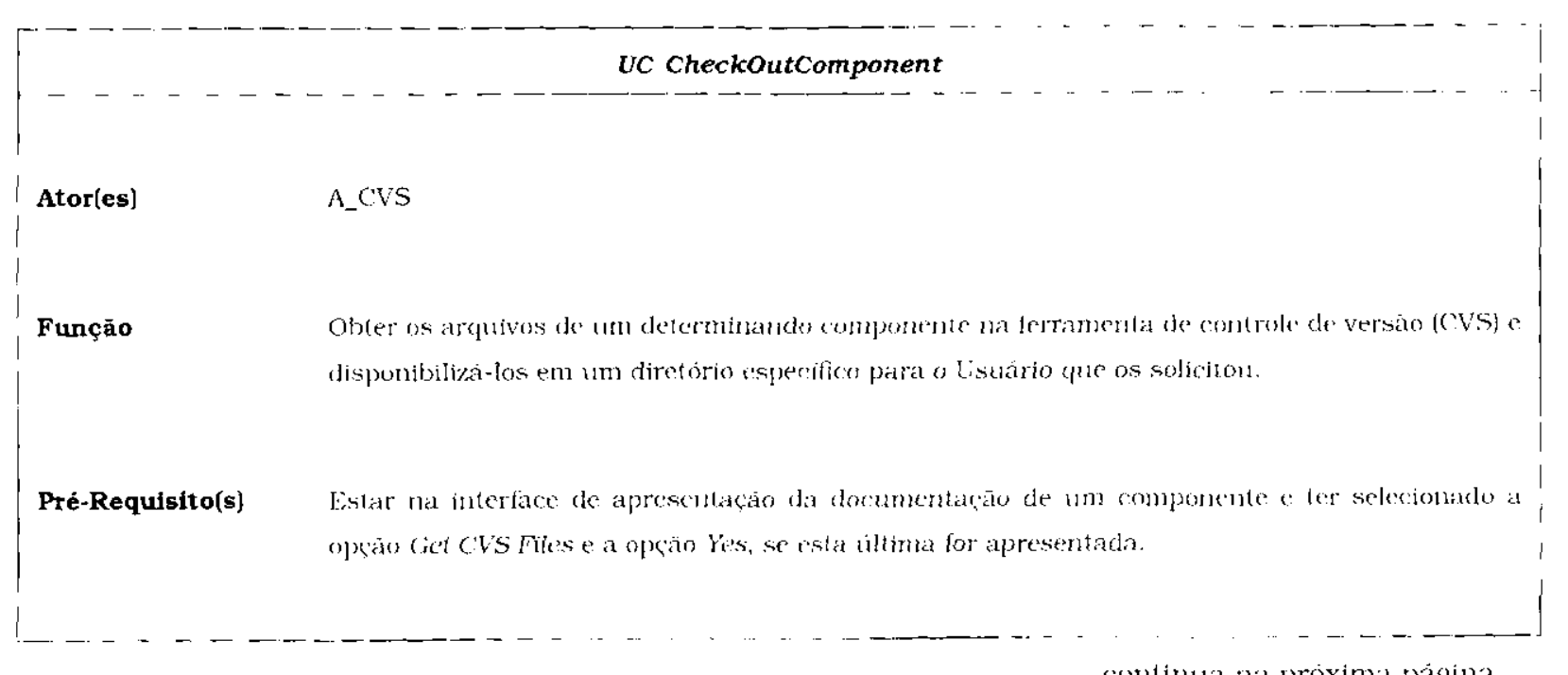

contimua na proxima página... 


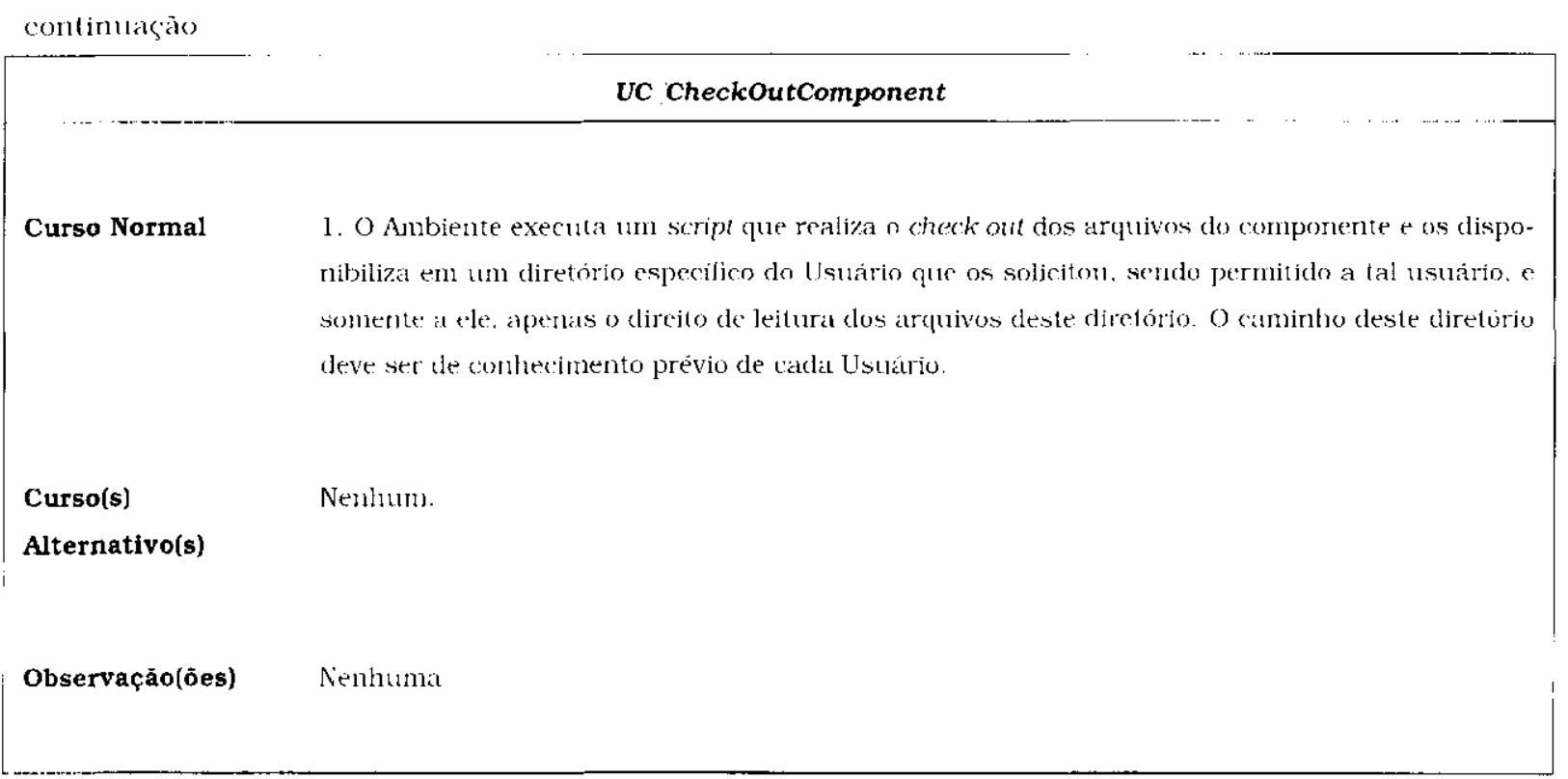

Tabela 9.9: Especificação de Caso de Uso - Obtenção da Documentação de um Componente

\section{Caso de Uso - Registro de Componentes do Tipo "Em Desenvolvimento"}

Neste caso de uso. cujo diagrama e especificação sāo apresentados, respectivamente, na Figura 9.7 e na Tabela 9.10, é descrita a atividade de registro de componentes que estão em desenvolvimento.

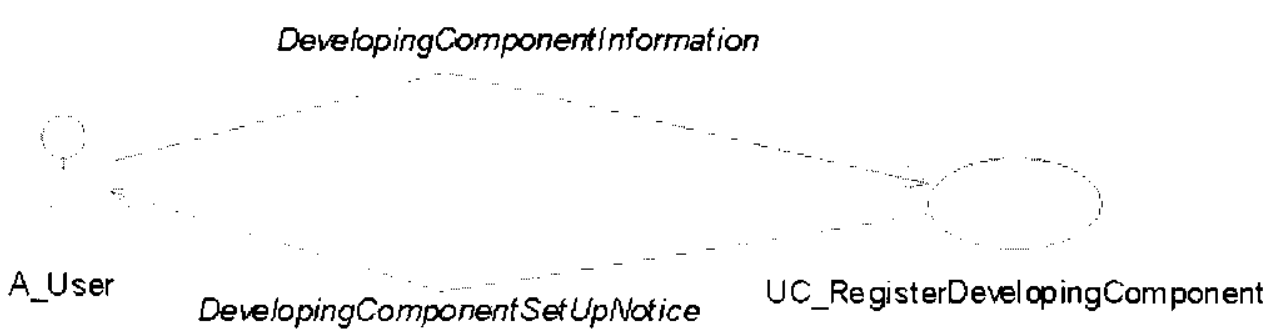

Figura 9.7: Diagrama de Caso de Uso - Registro de Componentes em Desenvolvimento

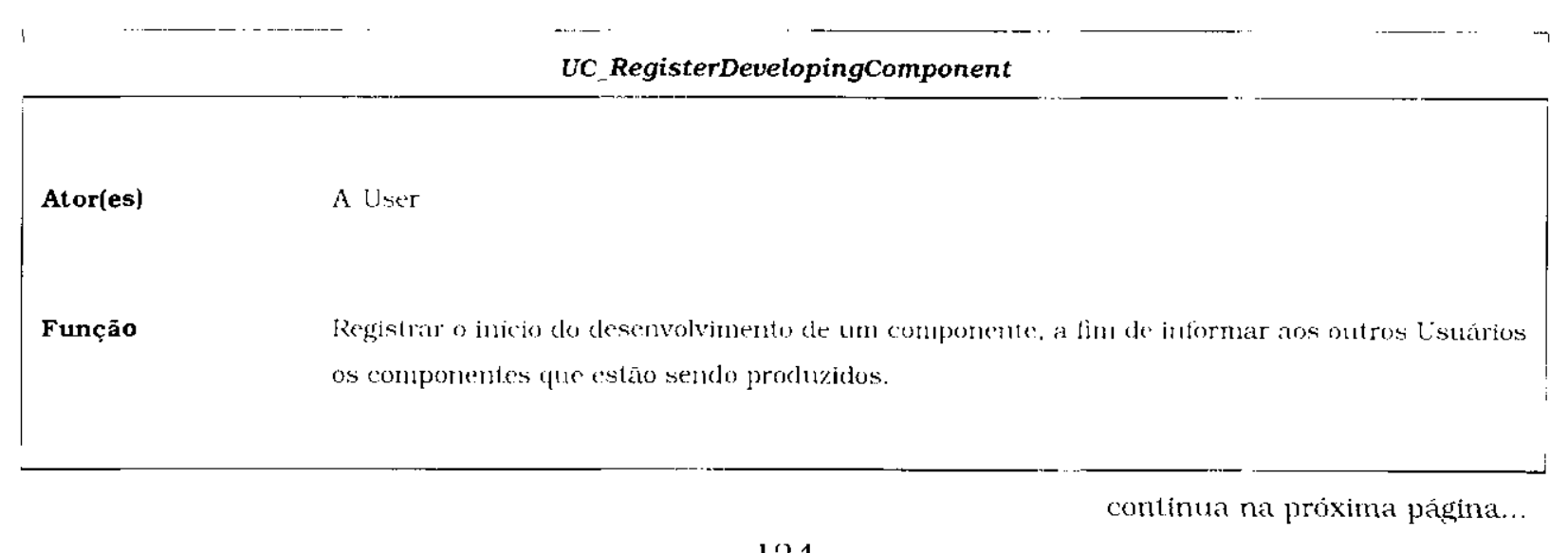




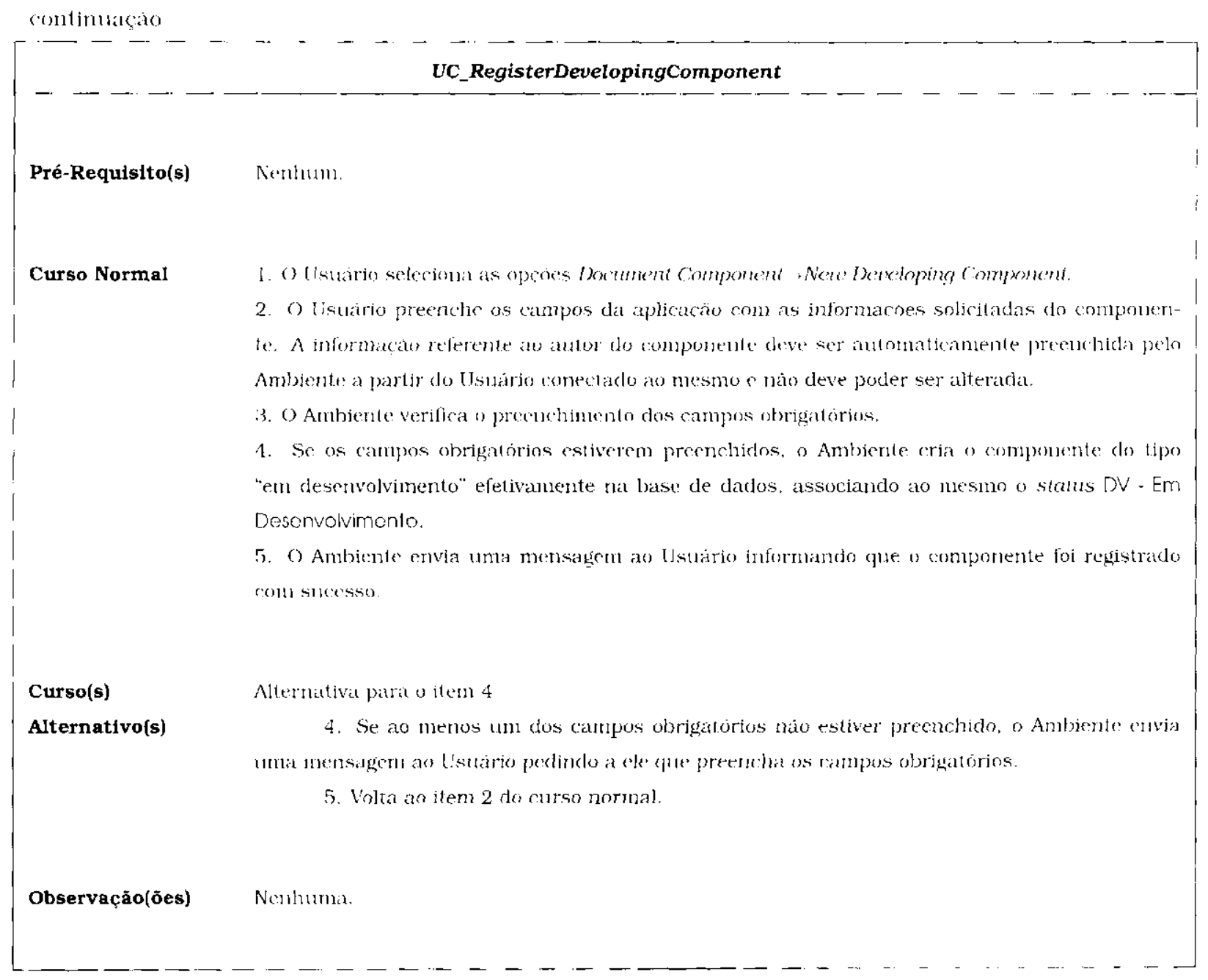

Tabela 9.10: Especificação de Caso de Uso - Registro de Componentes em Desenvolvimento

Caso de Uso - Registro do Cancelamento de Componentes do Tipo "Em Desenvolvimento"

Neste caso de uso, cujo diagrama e especificaçōes são apresentados, respectivamente. na Figura 9.8 e nas Tabelas 9.11 c 9.7. c descrita a atividade de cancelamento do desenvolvimento de um determinado componente.

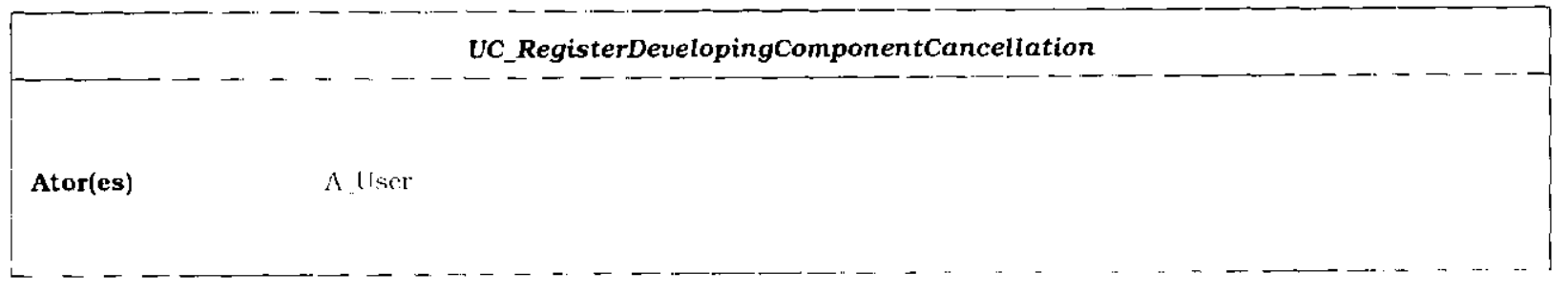

continua na próxima página. 


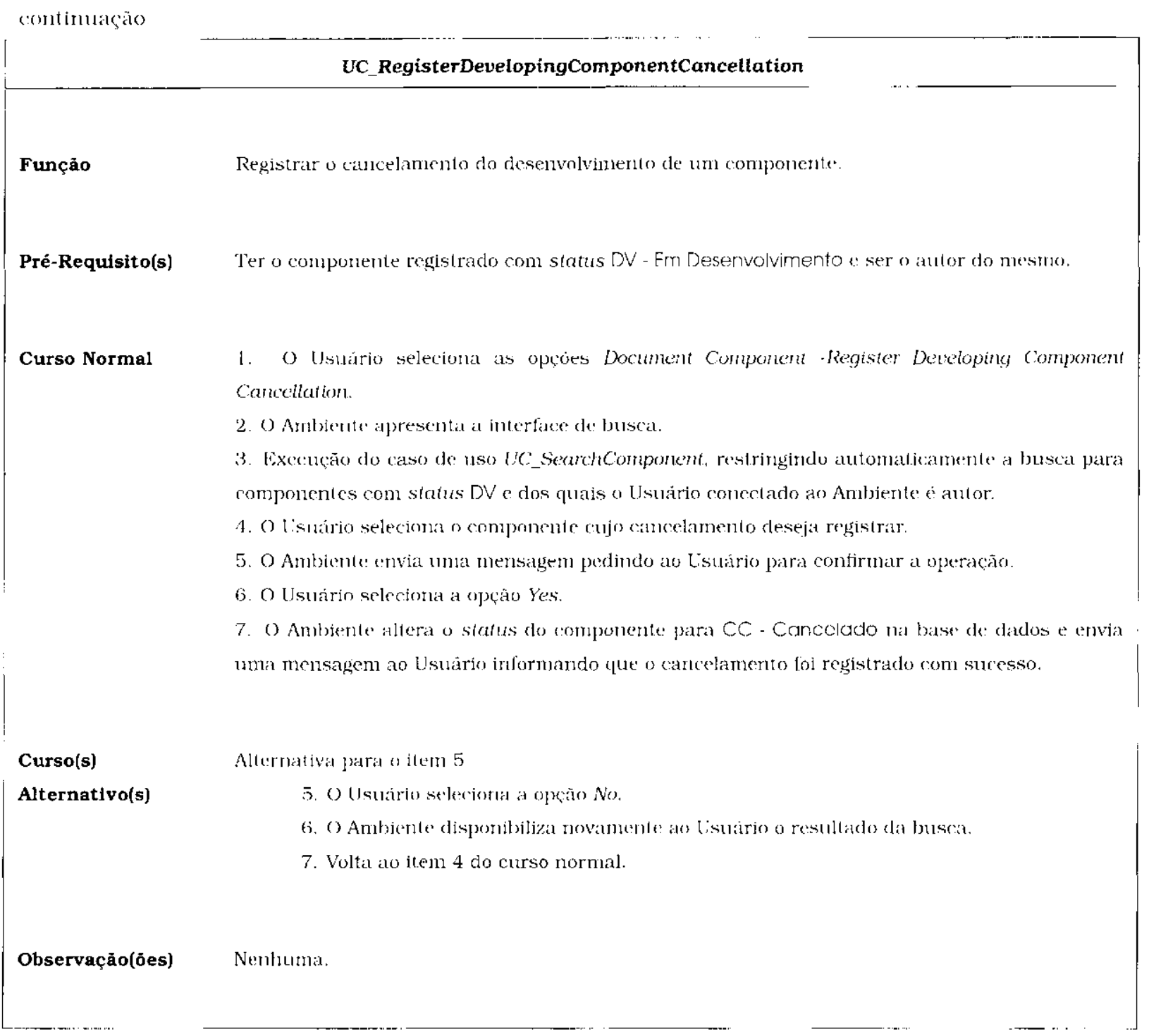

Tabela 9.11: Especificação de Caso de Uso - Registro do Cancelamento de um Componente em Desenvolvimento

\section{Caso de Uso - Registro de Novos Componentes}

Neste caso de uso, cujo diagrama e especificações são apresentados. respectivamente, na Figura 9.9 e nas Tabclas 9.12 c 9.7 , ć descrita a atividade de registro de novos componentes. 


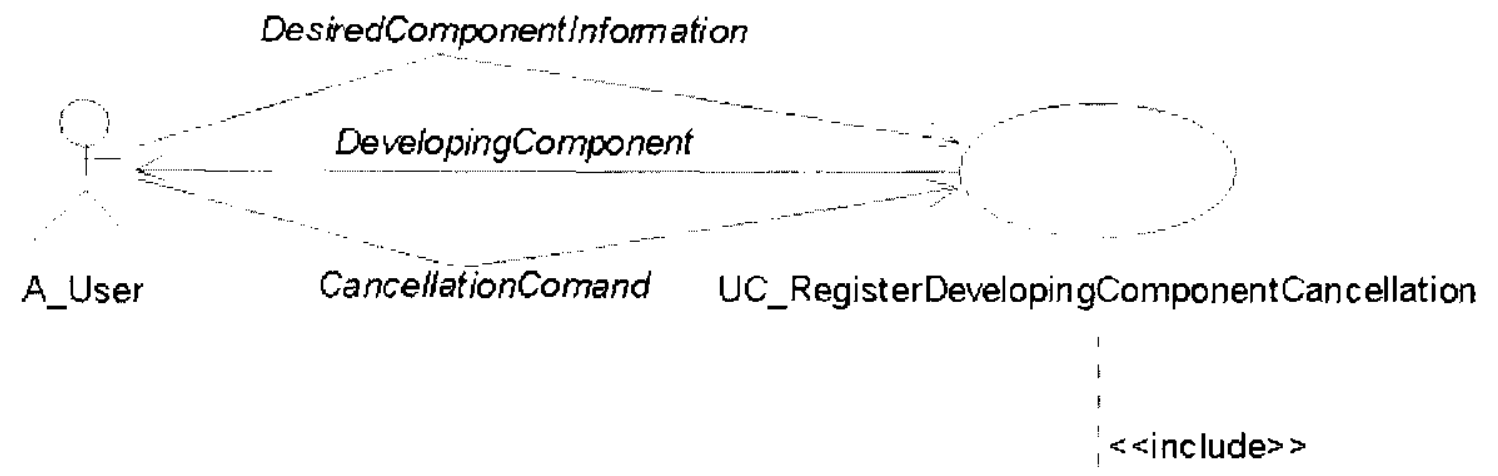

Desired Componen tinform ation

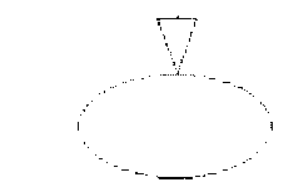

UC_SearchComponent

Figura 9.8: Diagrama de Caso de Uso - Registro do Cancelamento de um Componente em Desenvolvimento

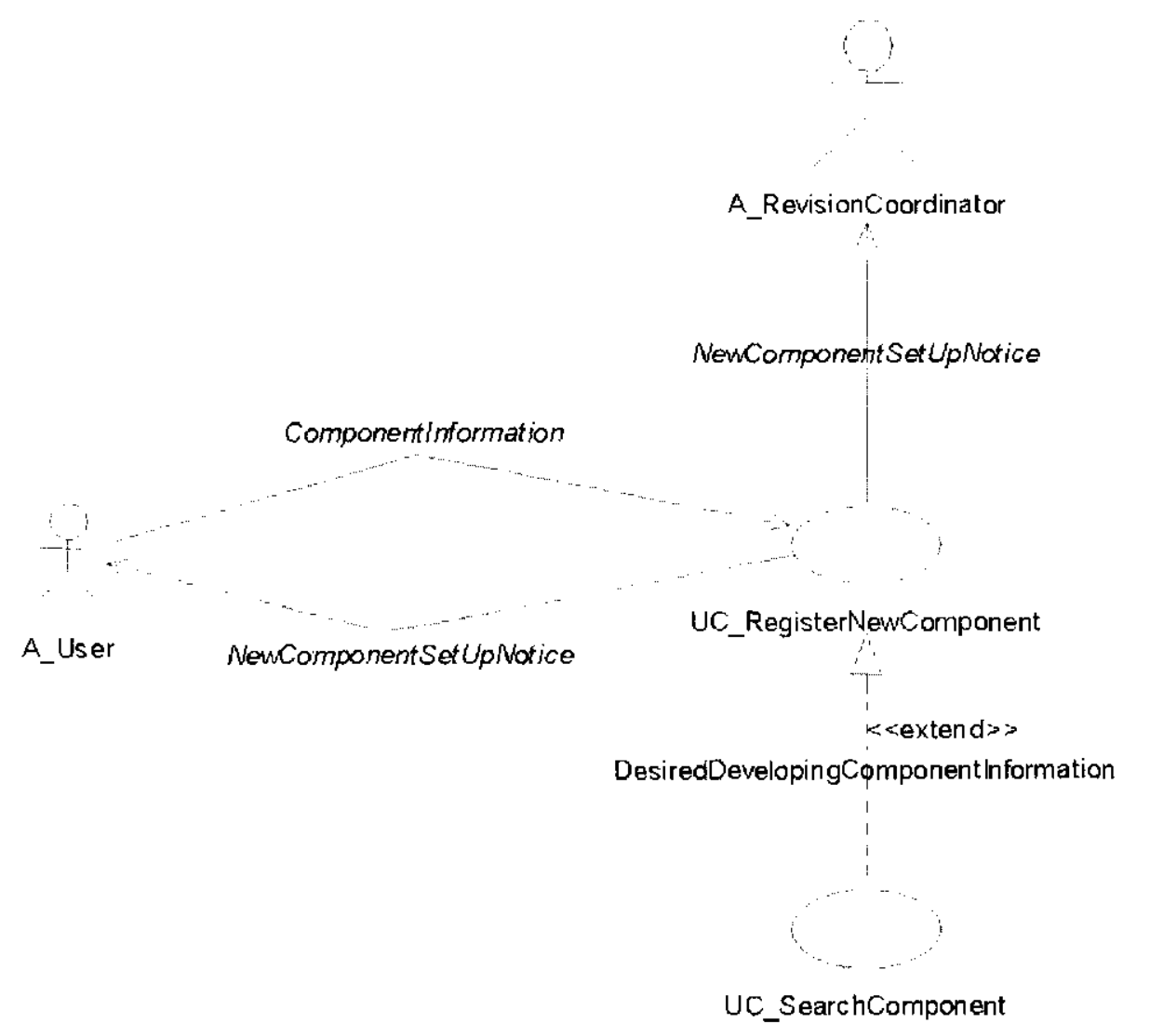

Figura 9.9: Diagrama de Caso de Uso - Registro de Novos Componentes 


\begin{tabular}{|c|c|}
\hline & UC_RegisterNewComponent \\
\hline Ator(es) & $A_{-}$User \\
\hline Função & $\begin{array}{l}\text { Documentar e registrar um componente finalizado e. posteriormente. disponibilizä-lo para o pro- } \\
\text { cesso do revisāo. }\end{array}$ \\
\hline Pré-Requisito(s) & Nenhum. \\
\hline Curso Normal & 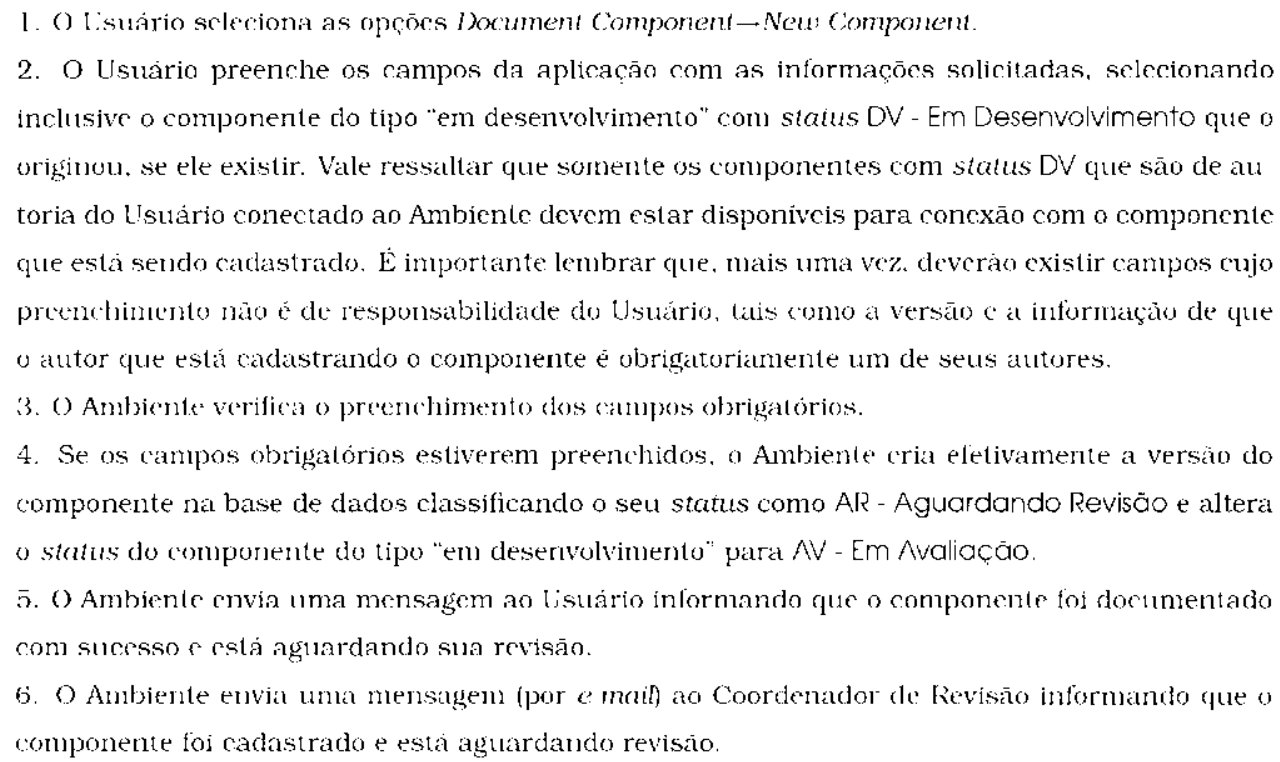 \\
\hline $\begin{array}{l}\text { Curso(s) } \\
\text { Alternativo(s) }\end{array}$ & 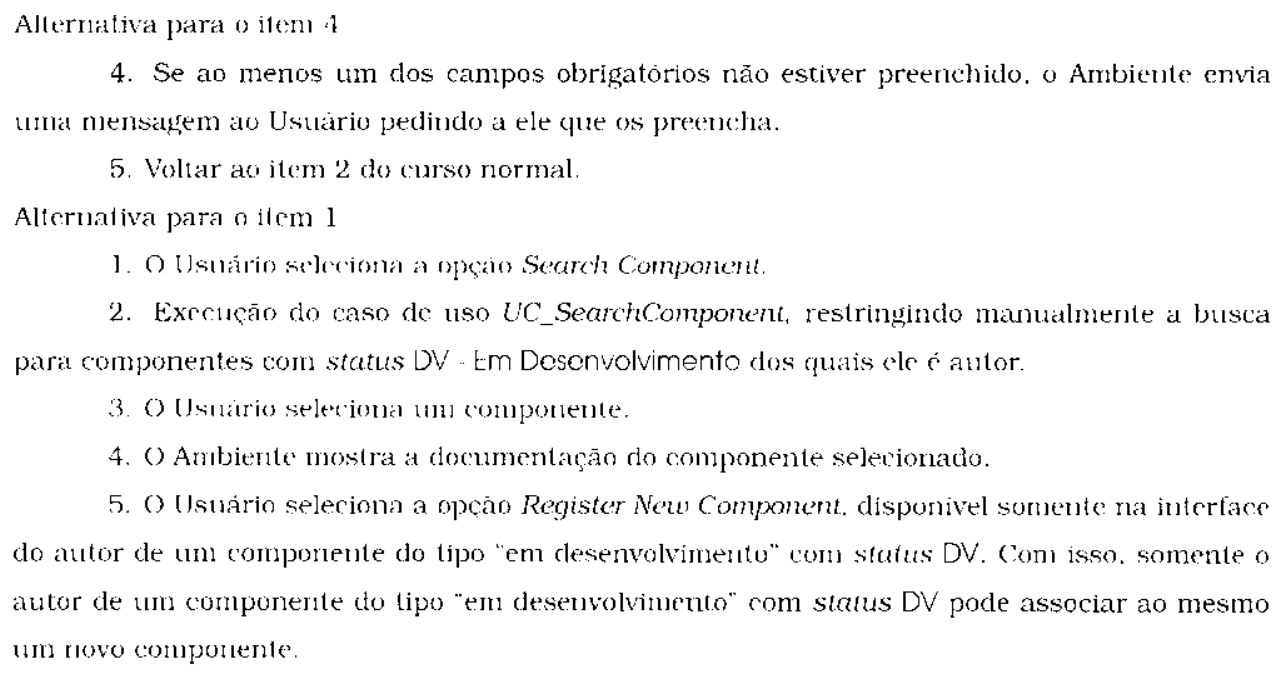 \\
\hline
\end{tabular}

continua na proxima pặ̆na... 


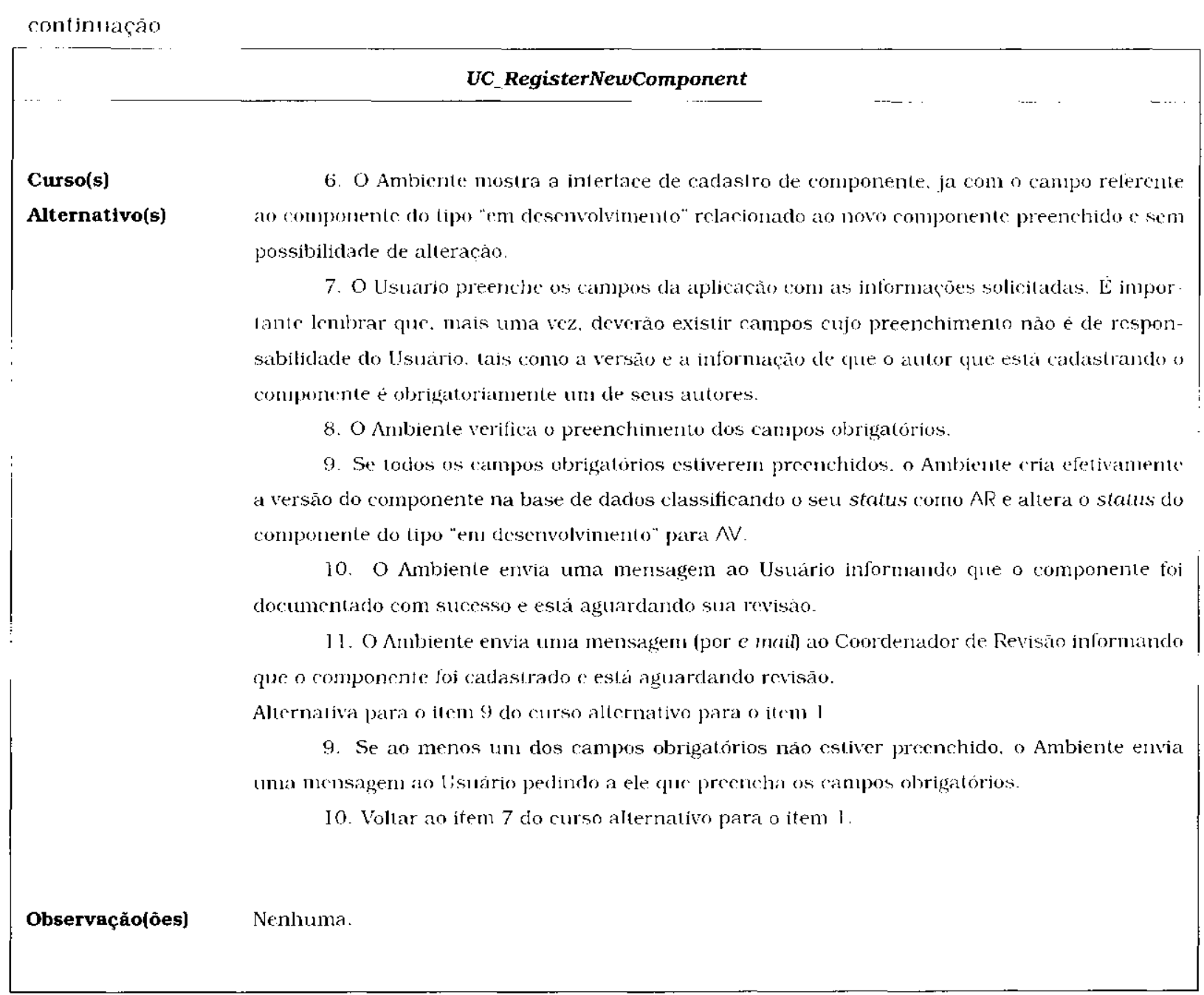

Tabela 9.12: Especificaçào de Caso de Uso - Registro de Novos Componentes

\section{Caso de Uso - Seleção dos Revisores e do Lider da Revisão de um Componente}

Neste caso de uso. cujo diagrama e especificaçāo são apresentados, respectivamentc, na Figura 9.10 e na Tabela 9.13, é descrita a atividade de seleção dos revisores c do líder da revisão de um componente.

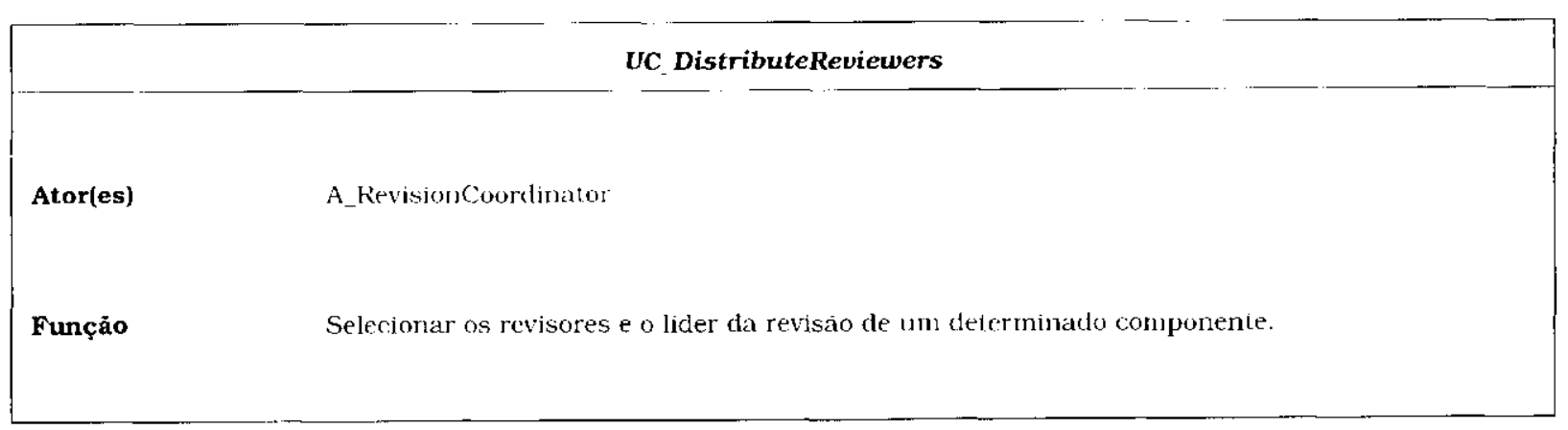

continua na proxima página... 


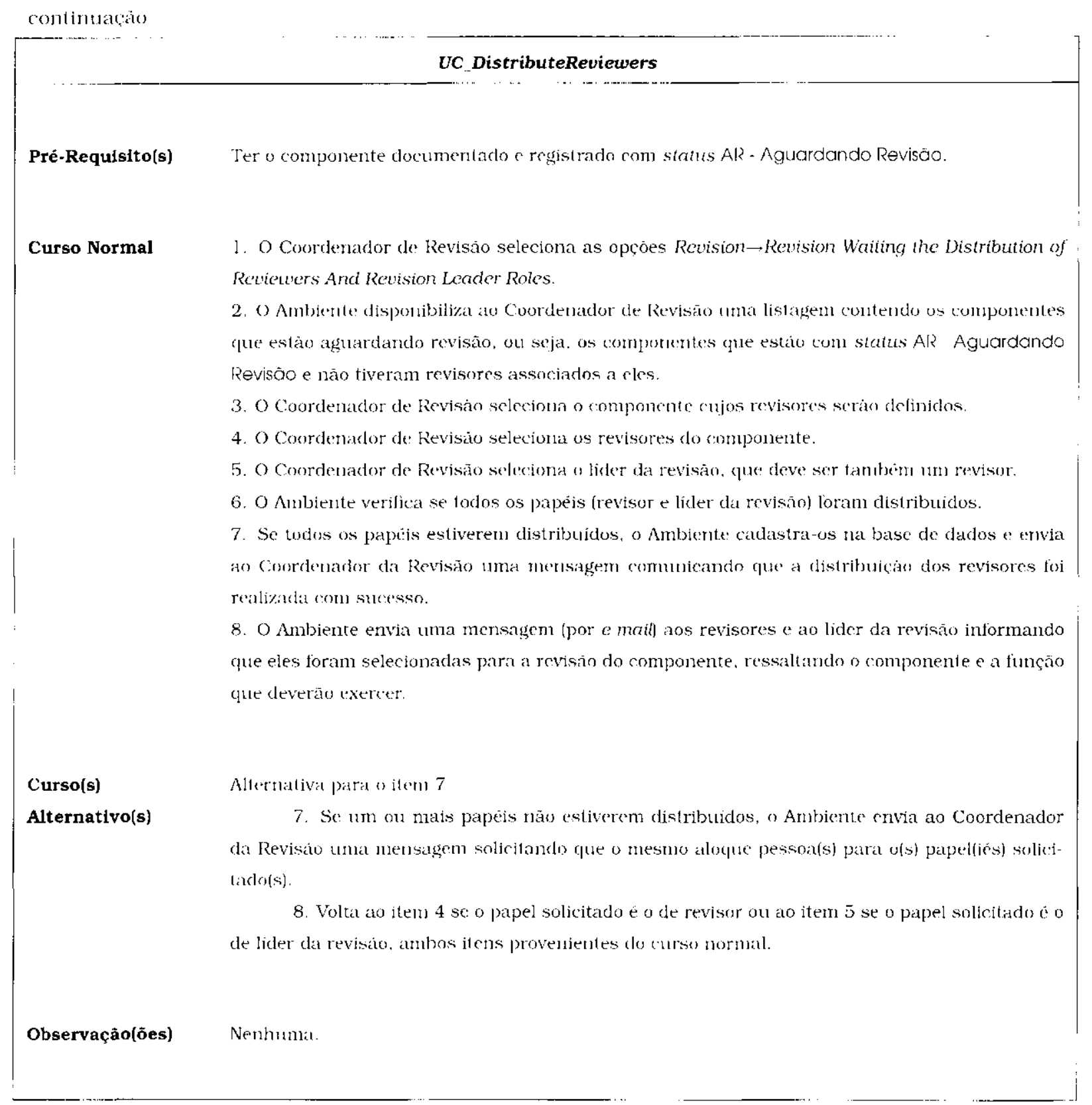

Tabela 9.13: Especificacāo de Caso de Uso - Selecão dos Revisores e do Lider da Revisão de um Componente

\section{Caso de Uso - Agendamento da Reunião de Revisão de um Componente}

Neste (aso de uso, cujo diagrama e especificacão são apresentados, respectivamente, na Figura 9.11 e na Tabela 9.14, é descrita a atividade de agendamento da reuniāo de revisāo de un determinado componente. 


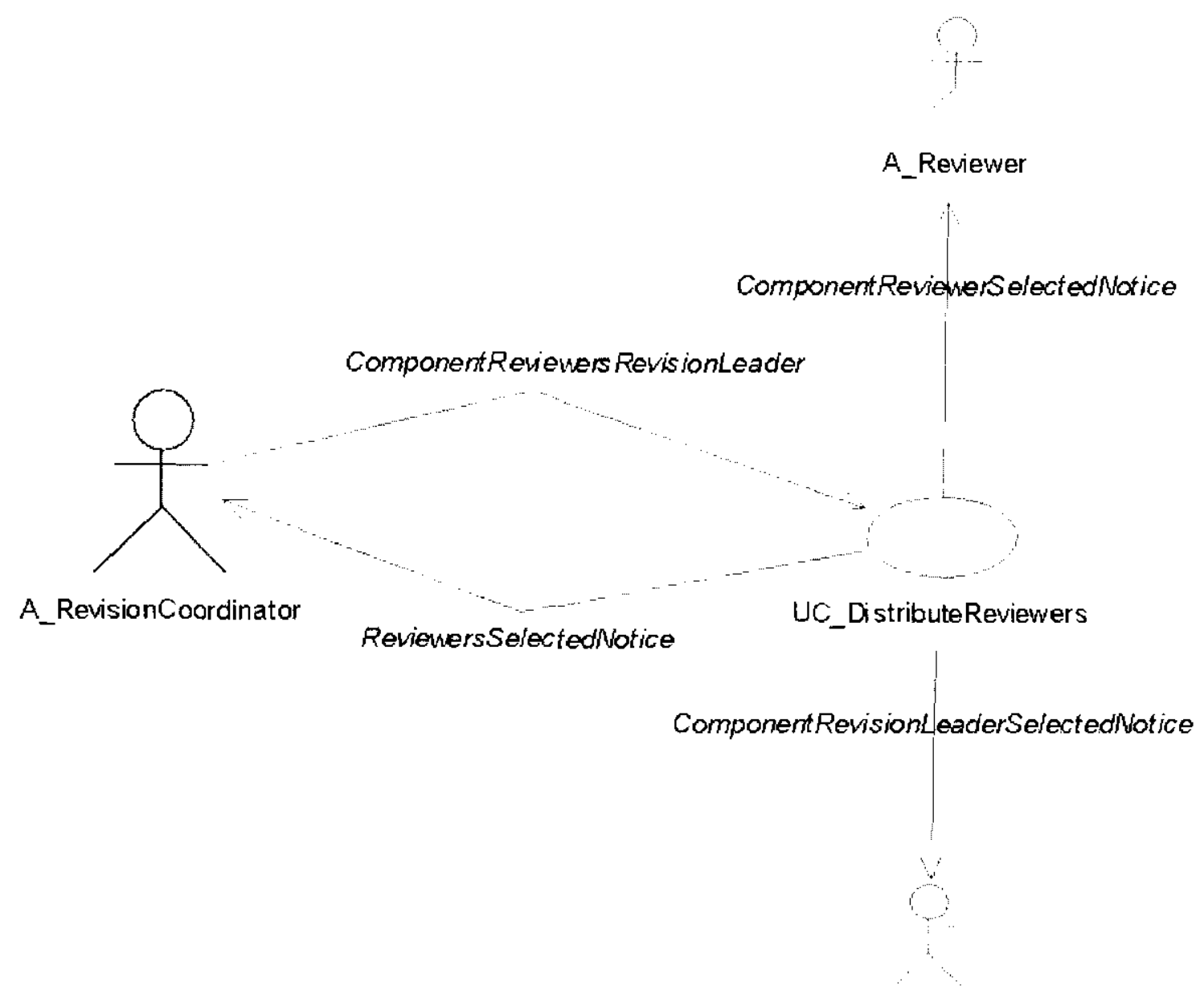

\section{A_RevisionLeader}

Figura 9.10: Diagrama de Caso de Uso - Selecão dos Revisores e do Lider da Revisão de um Componente

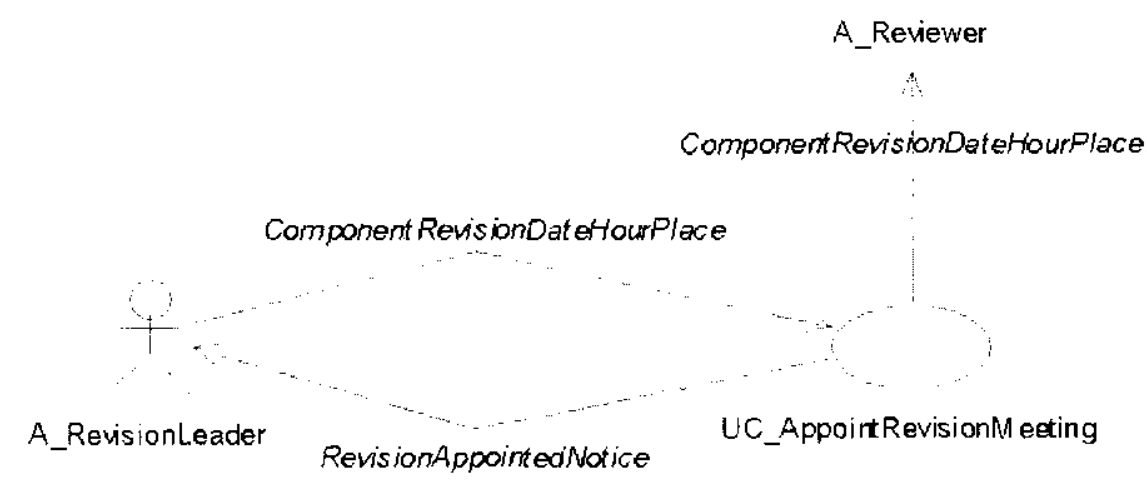

Figura 9.11: Diagrama de Caso de Uso Agendamento da Reuniāo de Revisāo de um Componente 


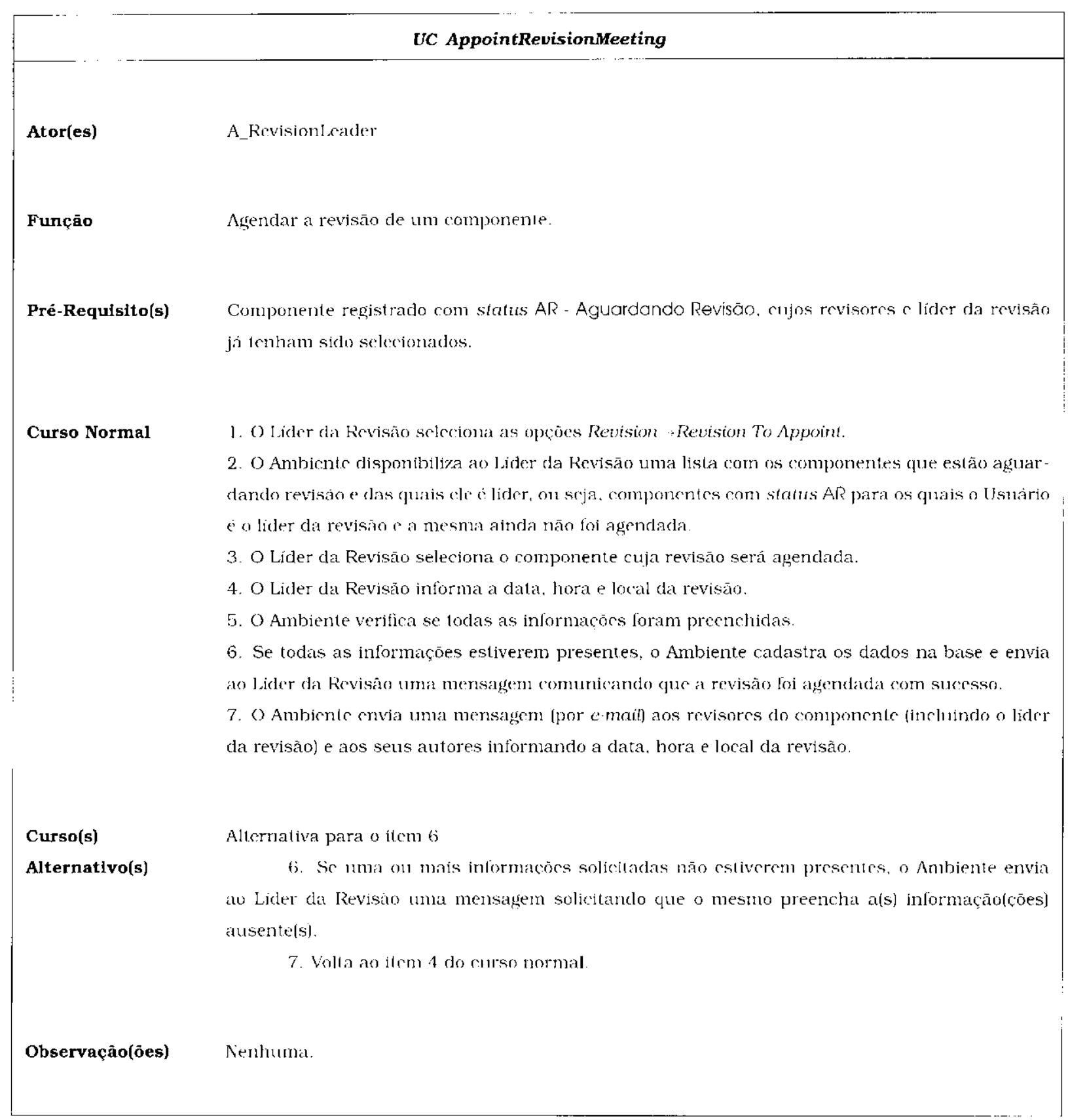

Tabela 9.14: Especificação de Caso de Uso - Agendamento da Reuniāo de Revisāo de um Componente

Caso de Uso - Visualização dos Componentes Selecionados para Serem Revisados por um Determinado Revisor

Neste caso de uso, cujo diagrama e especificação são apresentados, respectivamente, na Figura 9.12 c na Tabcla 9.15. ć descrita a atividade de visualização dos componentes selecionados para serem revisados por um determinado revisor. 


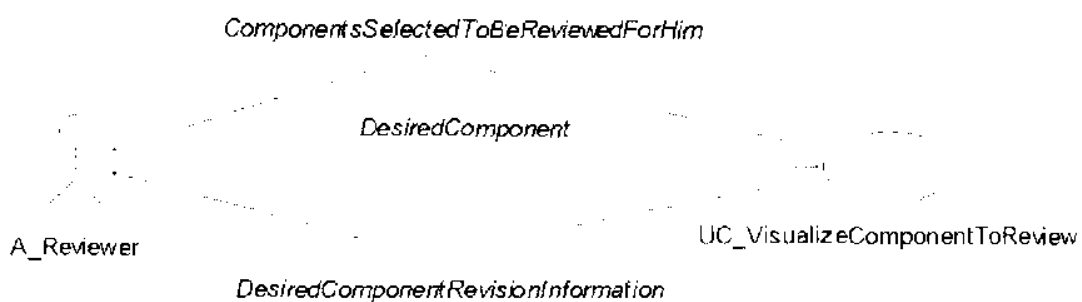

Figura 9. 12: Diagrama de Caso de Uso - Visualização dos Componentes Sclccionados para Serem Revisados por um Determinado Revisor

\begin{tabular}{|c|c|}
\hline & UC_VisualizeComponentToReview \\
\hline Ator(es) & A_Reviewer \\
\hline Função & Visualizar os componentes que devem ser revisados pelo Revisor conectado ao Antbiente. \\
\hline Pré-Requisito(s) & Nenbuns. \\
\hline Curso Normal & 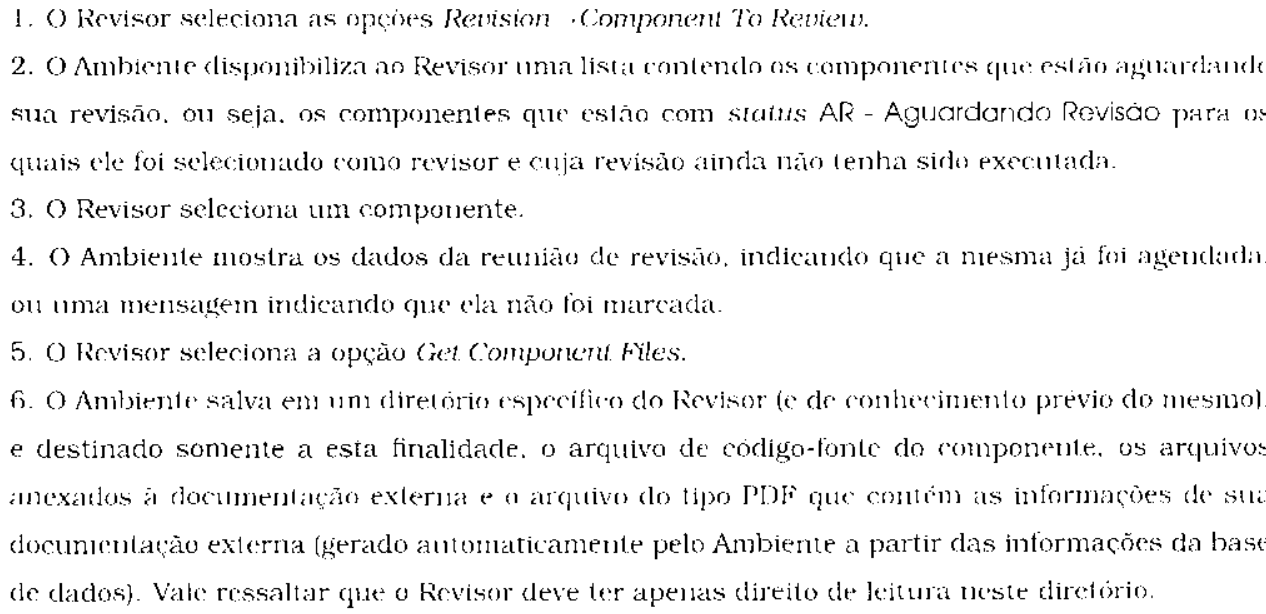 \\
\hline $\begin{array}{l}\text { Curso(s) } \\
\text { Alternativa(s) }\end{array}$ & Neniluum. \\
\hline Observação(ōes) & Nenhumla. \\
\hline
\end{tabular}

Tábela 9.15: Especificação de Caso de Uso - Visualização dos Componerites Selecionados para Serem Revisados por um Determinado Revisor 


\section{Caso de Uso - Cadastro do Resultado de uma Revisão de um Componente}

Ncste caso de uso, cujo diagrama e especificaçôes sāo apresentados, respectivamente, na Figura 9.13 e nas Tabelas 9.16. 9.17 e 9.18 , é descrita a atividade de cadastro do resultado de uma revisão de um componente.

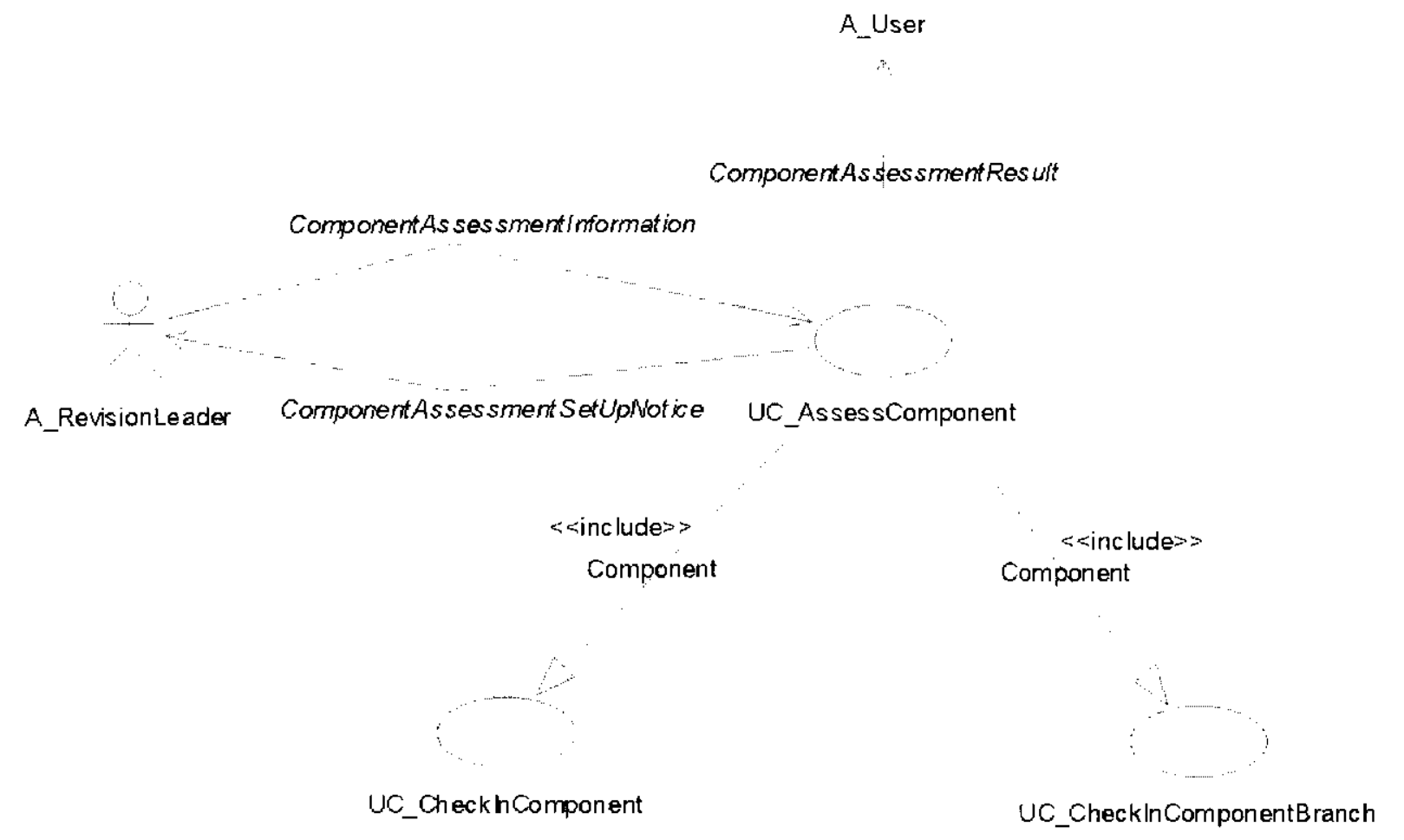

Figura 9.13: Diagrama de Caso de Uso - Cadastro do Resultado de uma Revisão de um Componente

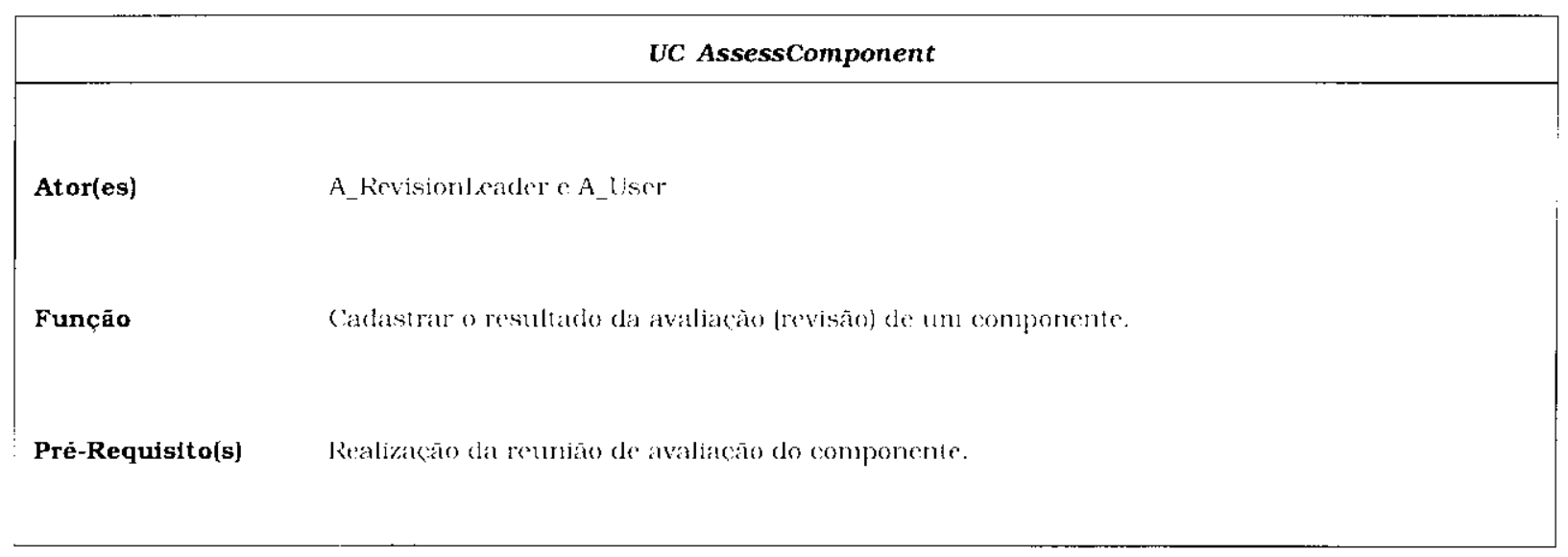

continua na proxima página. 


\begin{tabular}{|c|c|}
\hline & UC_AssessComponent \\
\hline Curso Normal & 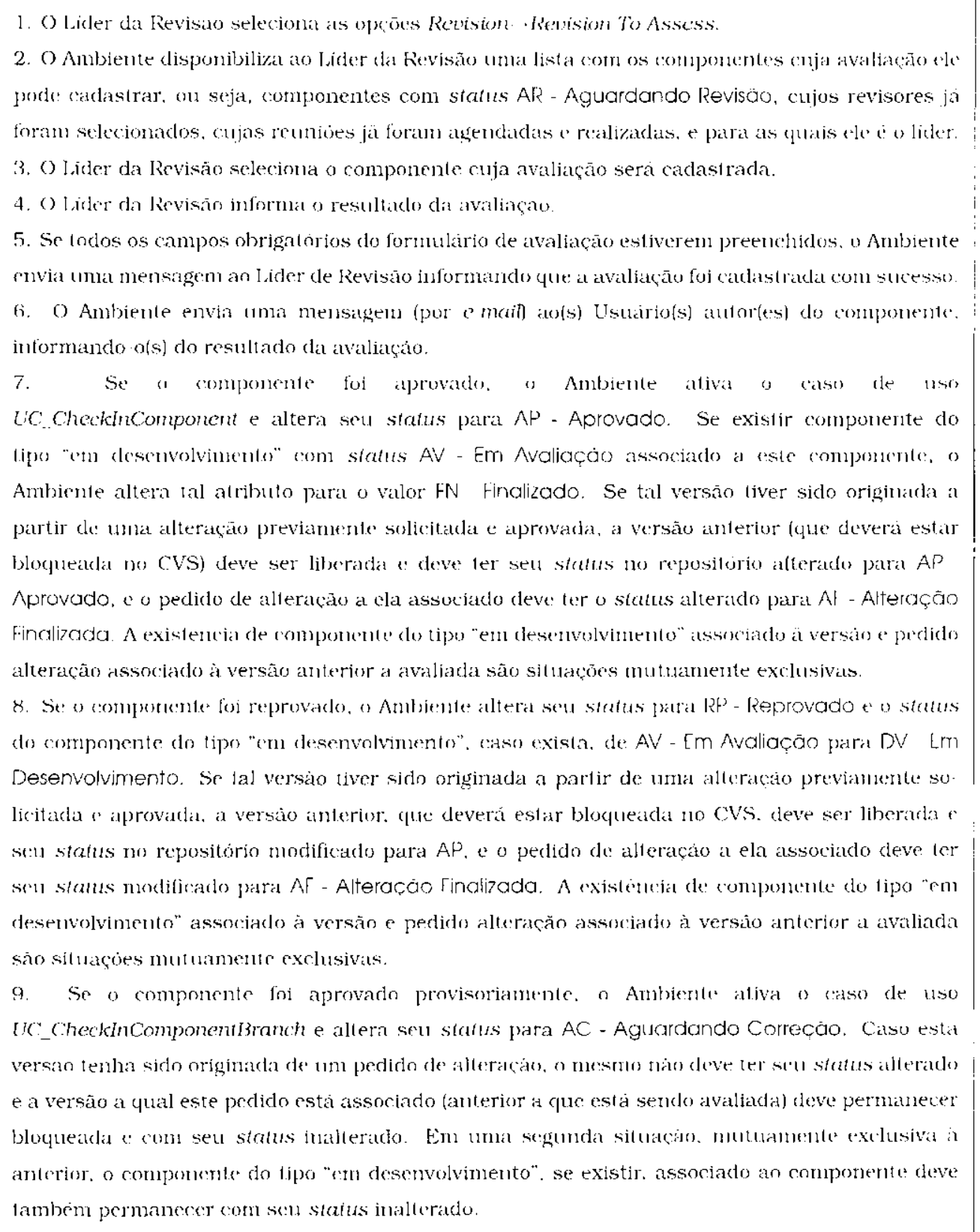 \\
\hline $\begin{array}{l}\text { Curso(s) } \\
\text { Alternativo(s) }\end{array}$ & 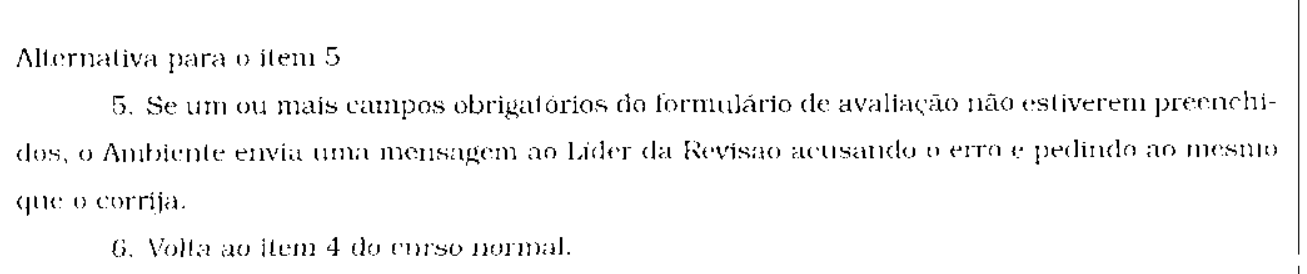 \\
\hline
\end{tabular}




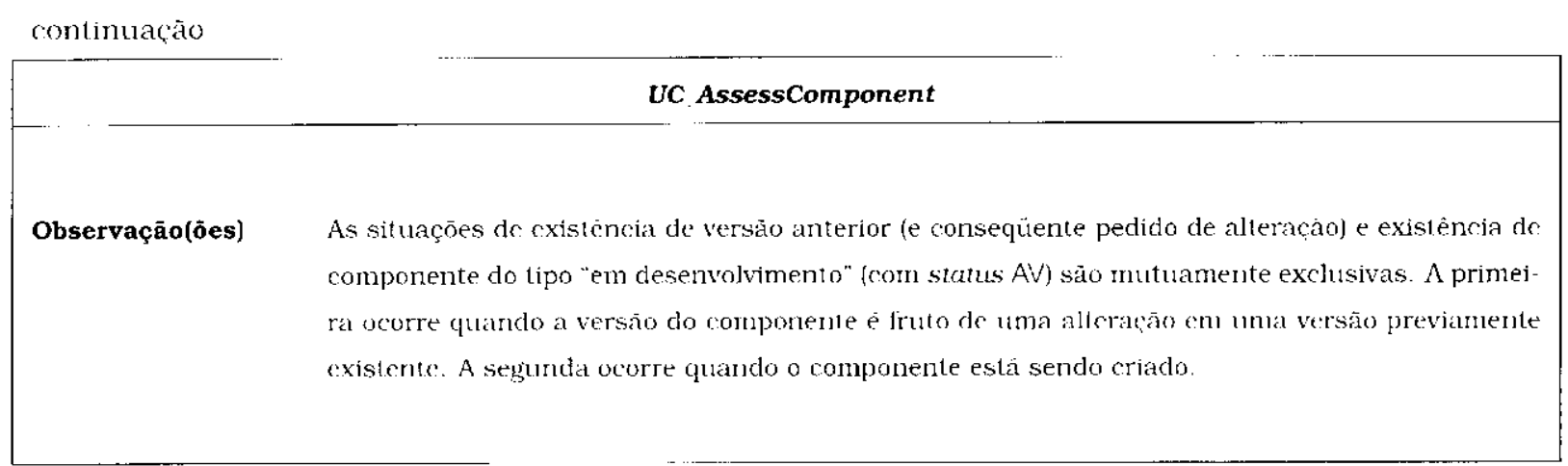

Tabela 9.16: Especificaçāo de Caso de Uso - Cadastro do Resultado de uma Revisāo de um Componente

\section{UC CheckInComponent}

\begin{tabular}{|c|c|}
\hline Ator(es) & Nenhumm. \\
\hline Funçāo & Inserir o componente e sua respectiva documentação externa na ferranenta de controle de versāo. \\
\hline Pré-Requisito(s) & 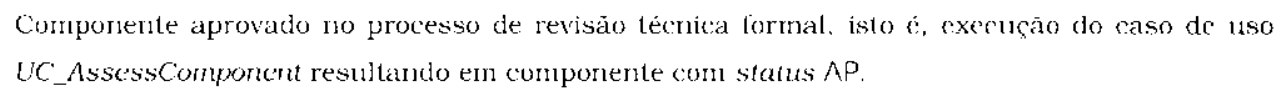 \\
\hline Curso Normal & 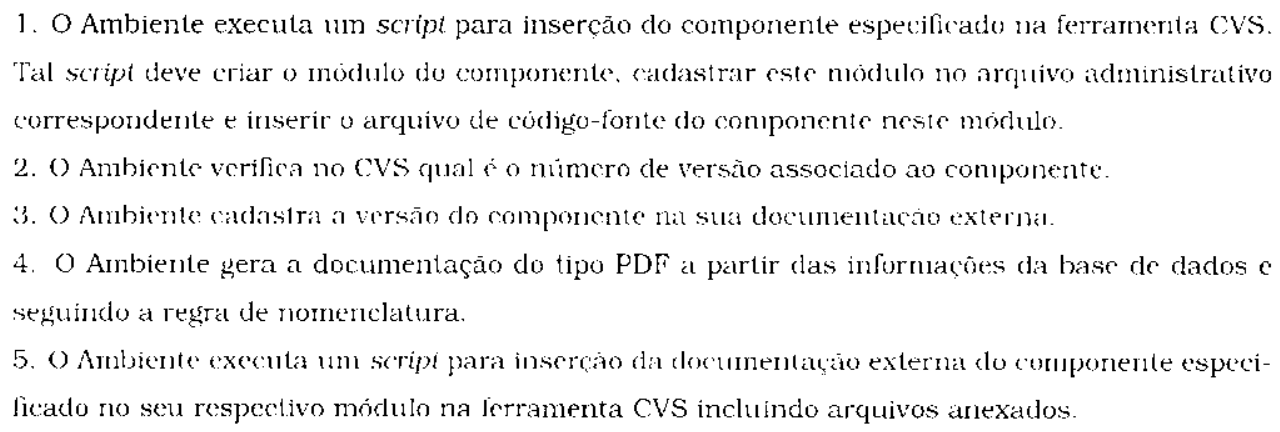 \\
\hline $\begin{array}{l}\text { Curso(s) } \\
\text { Alternativo(s) }\end{array}$ & Nentrum. \\
\hline
\end{tabular}

continua na próxima página... 


\section{Observaçāo(ōes) Nenhuıma.}

Tabela 9.17: Especilicaçāo de Caso de Uso - Inscrçāo de um Componente Aprovado no CVS

UC CheckInComponentBranch

\begin{tabular}{|c|c|}
\hline & UC CheckInComponentBranch \\
\hline Ator(es) & Nenhum. \\
\hline Funçāo & $\begin{array}{l}\text { Inserir o componente e sula resperliva documenlaçäo externa na lerramonla de controle de versāo } \\
\text { cVs. }\end{array}$ \\
\hline Pré-Requisito(s) & 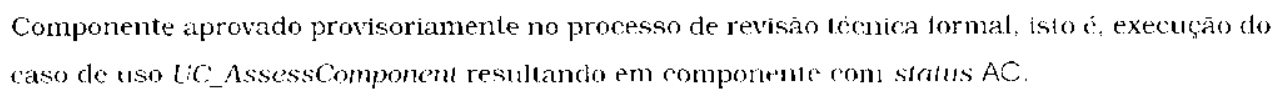 \\
\hline Curso Normal & 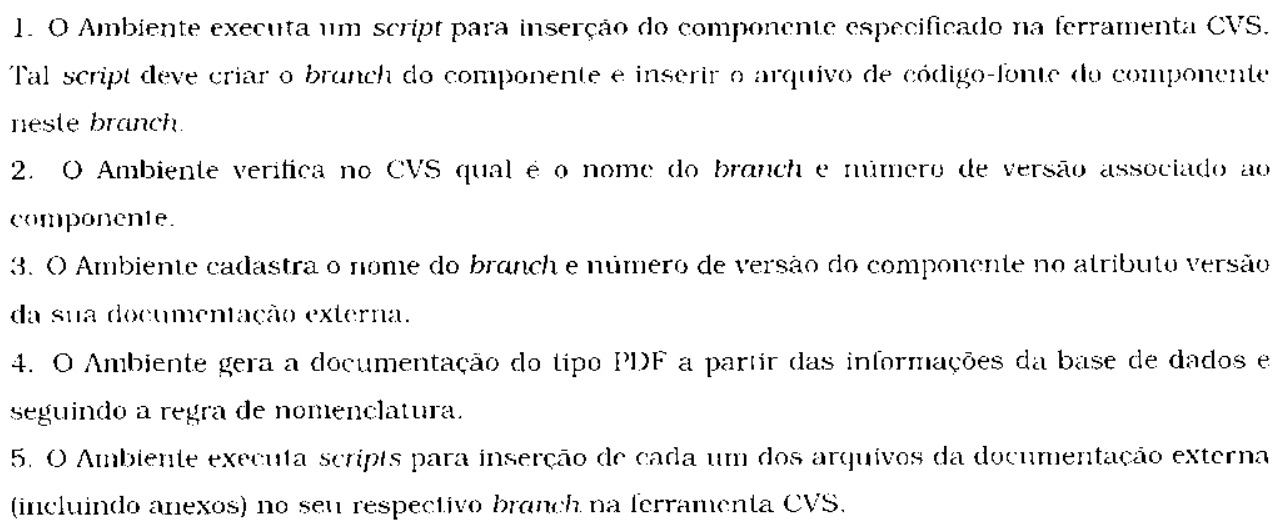 \\
\hline $\begin{array}{l}\text { Curso(s) } \\
\text { Alternativo(s) }\end{array}$ & Nenhum. \\
\hline
\end{tabular}

continud nla próxima página.. 


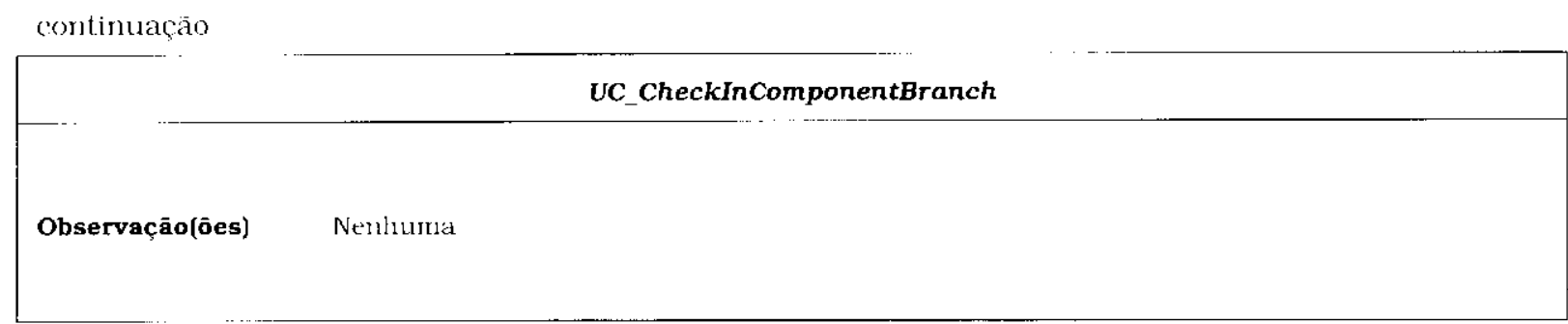

Tabela 9.18: Especificação de Caso de Uso - Inserção de um Componente Aprovado Provisoriamente no CVS

Caso de Uso - Visualizaçăo do Resultado de uma Revisăo de um Componente

Neste caso de uso, cujo diagrama e especificaçoes são apresentados, respectivamente. na Figura 9.14 c nas Tabelas 9.19 e 9.7, é descrita a atividade de visualização do resultado de uma revisão de um determinado componente.

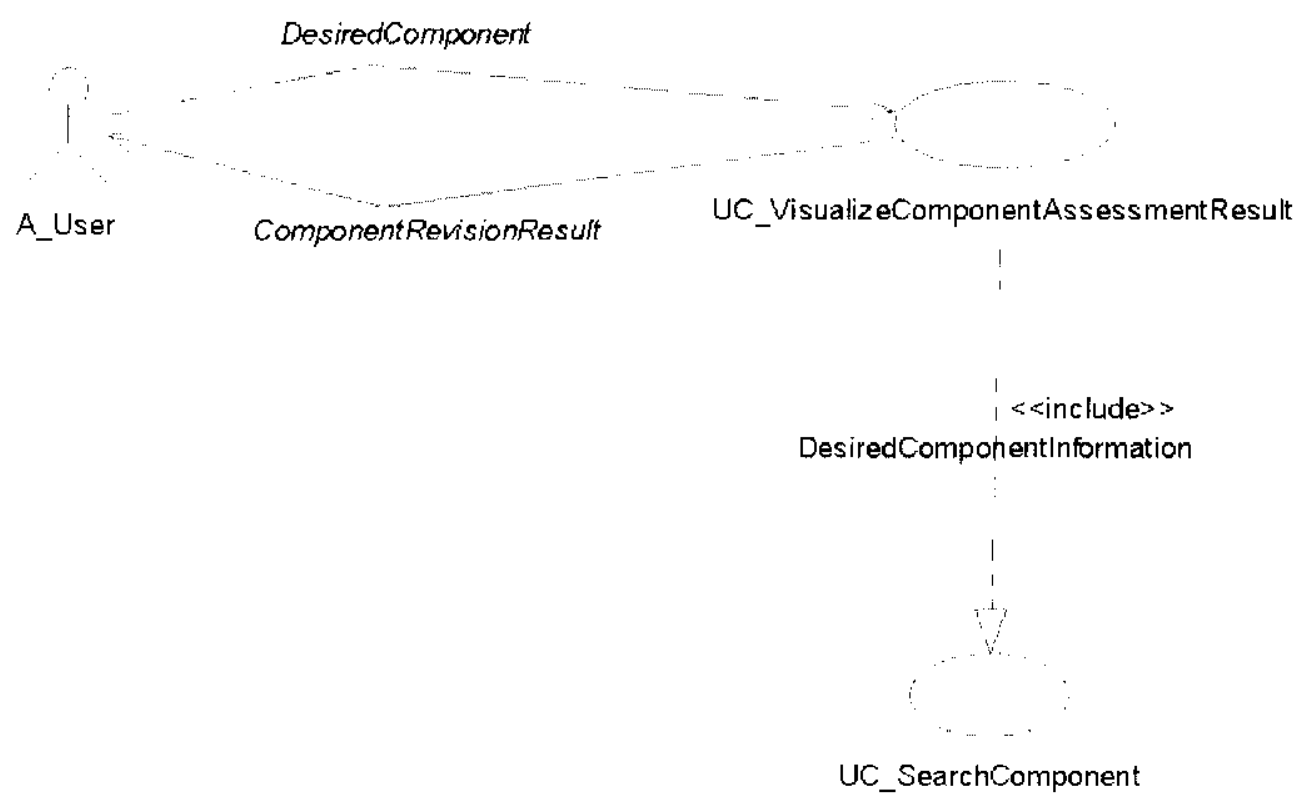

Figura 9.14: Diagrama de Caso de Uso - Visualizaçāo do Resultado de uma Revisāo de um Componente

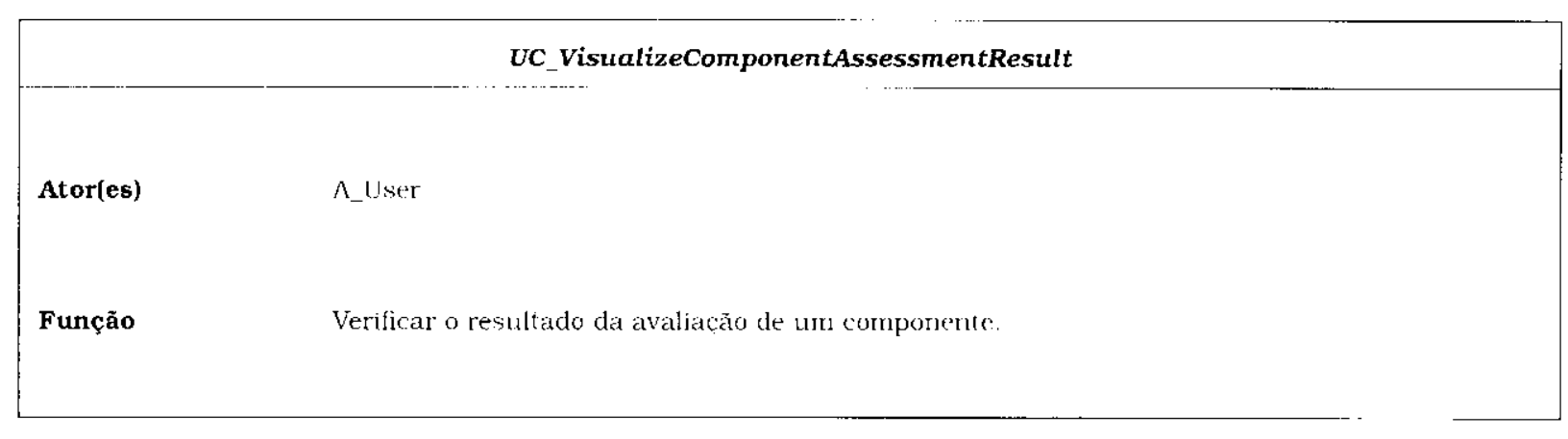




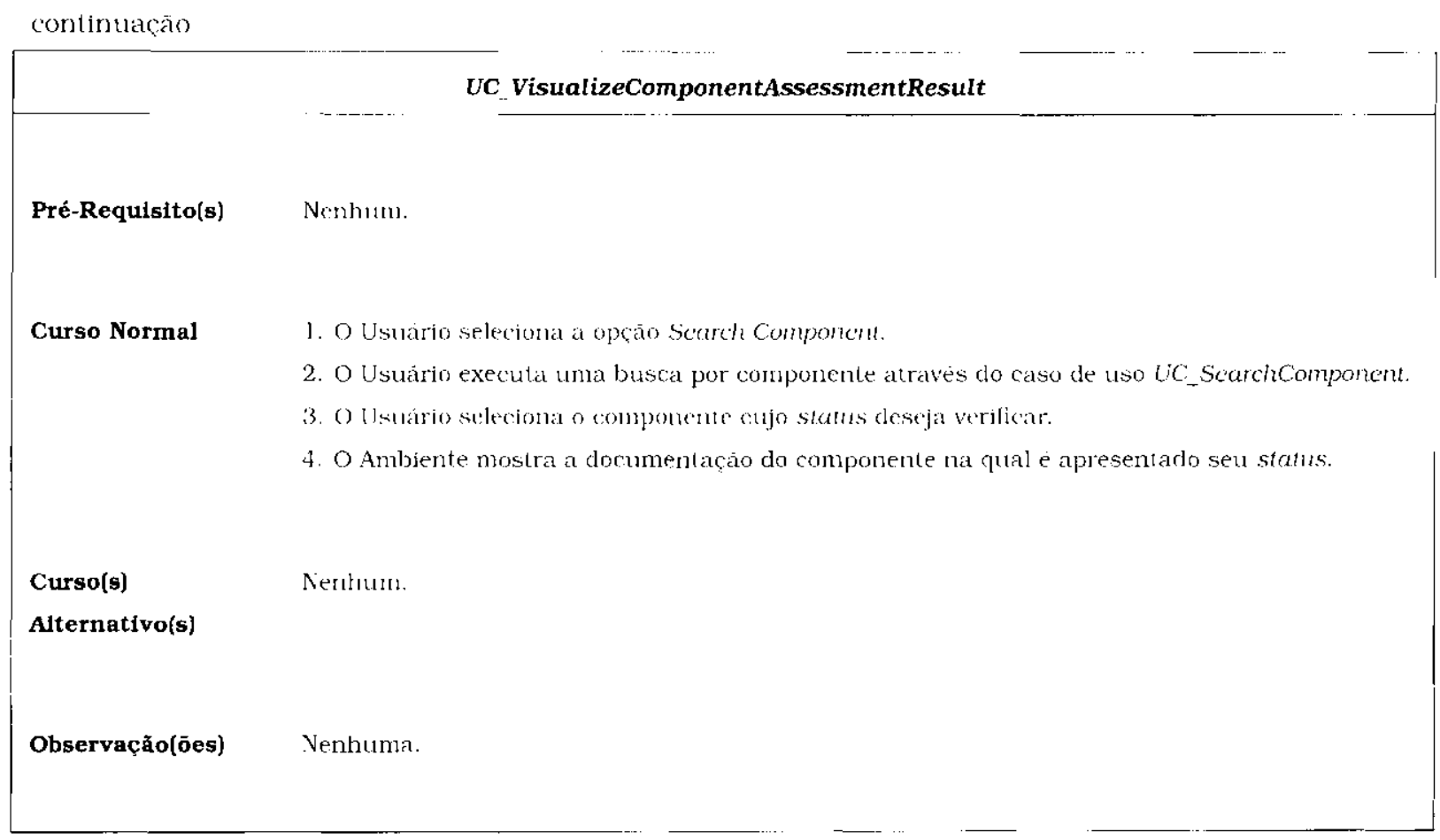

Tabela 9.19: Especificaçāo de Caso de Uso - Visualização do Resultado de uma Revisão de um Componente

\section{Caso de Uso - Solicitação de Pedido de Alteração}

Neste caso de uso, cujo diagrama e especificaçōcs são apresentados, respectivamente. na Figura 9.15 e nas Tabelas 9.20 e 9.7. é descrita a atividade de solicitaçáo de pedido de alteraçāo para um detcrminado componente.

\begin{tabular}{|c|c|}
\hline & UC_ComponentChangeRequest \\
\hline Ator(es) & A_liser \\
\hline Função & Solicitar a alteraçào de um componente. \\
\hline Pré-Requisito(s) & 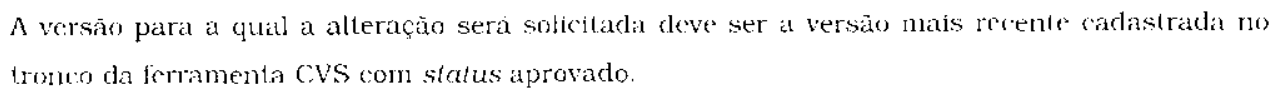 \\
\hline
\end{tabular}

continua na próxima página... 


\begin{tabular}{|c|c|}
\hline & UC_ComponentChangeRequest \\
\hline Curso Normal & 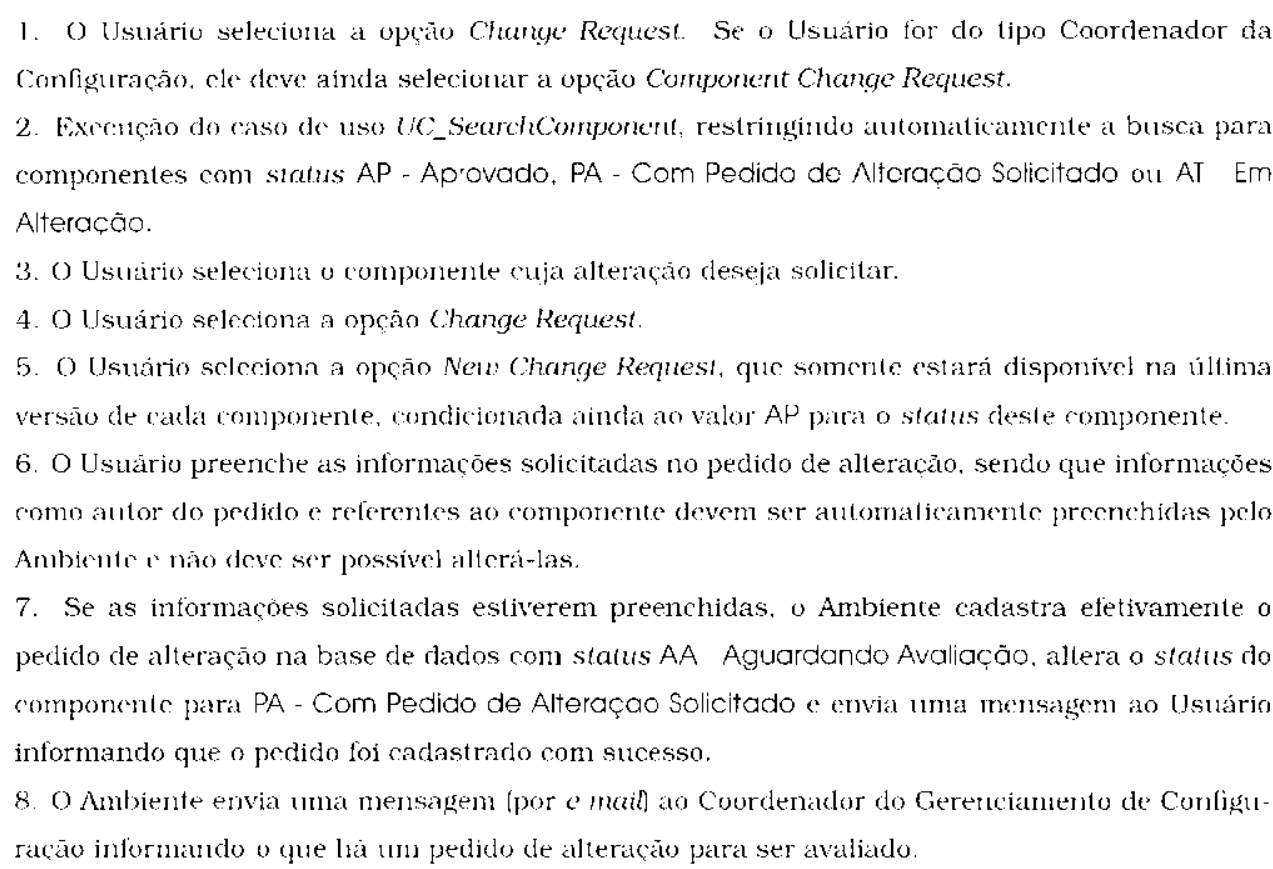 \\
\hline $\begin{array}{l}\text { Curso(s) } \\
\text { Alternativo(s) }\end{array}$ & 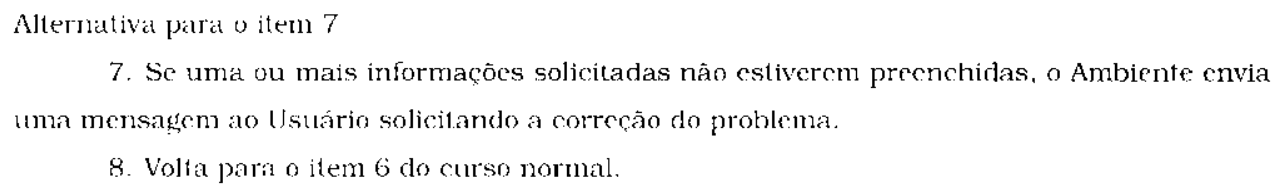 \\
\hline Observaçāo(ōes) & Nenhuma. \\
\hline
\end{tabular}

Tábcla 9.20: Espccificação de Caso de Uso - Solicilação de Pedido de Nlteraçāo

\section{Caso de Uso - Visualização dos Pedidos de Alteração a Serem Avaliados}

Nestc caso de uso, cujo diagrama e especificacào são apresentados. respcctivamente, na Figura 9.16 e na Tabela 9.21 , é descrita a atividade de visualização dos pedidos de altcraçào ainda não avaliados. 


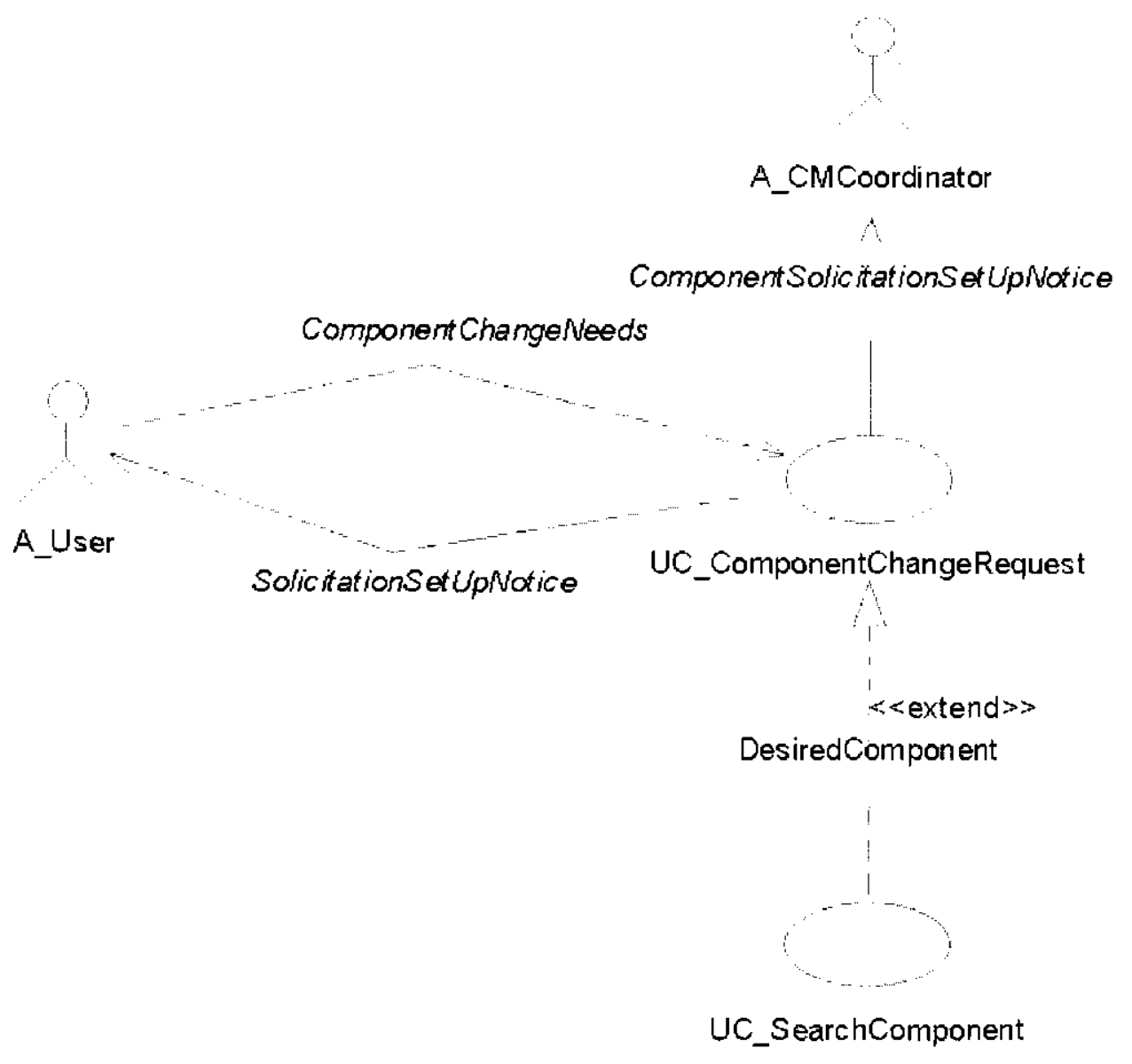

Figura 9.15: Diagrama de Caso de Uso - Solicitação de Pedido de Alteração

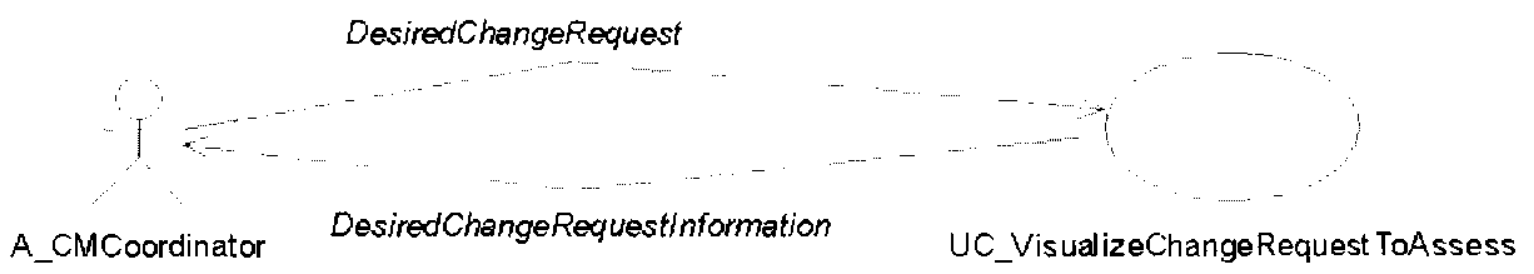

Figura 9.16: Diagrama de Caso de Uso - Visualização dos Pedidos de Alteração a Serem Avaliados

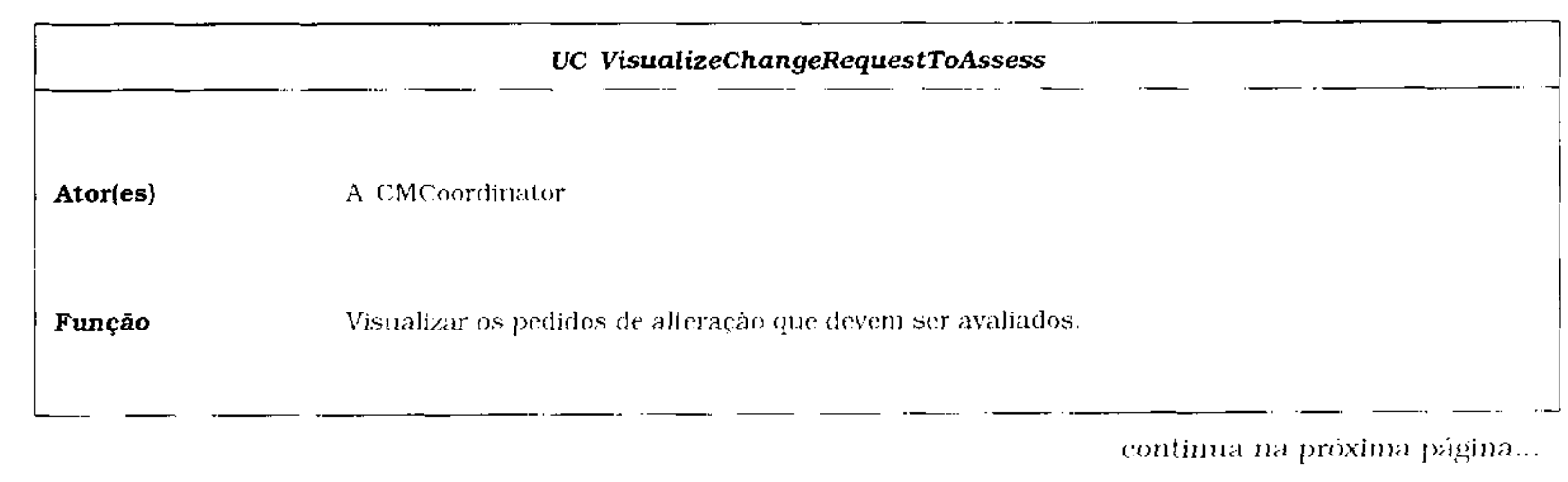




\begin{tabular}{|c|c|}
\hline & UC_VisualizeChangeRequestToAssess \\
\hline Pré-Requisito(s) & Nenhum. \\
\hline Curso Normal & 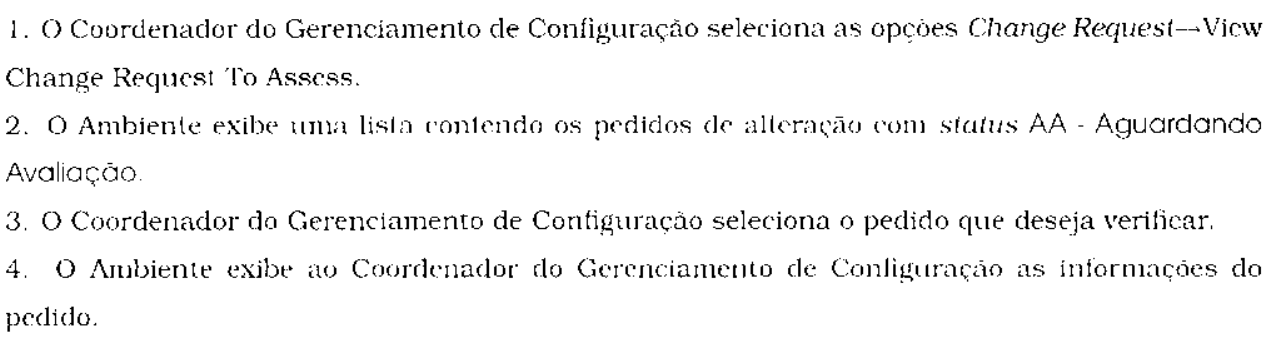 \\
\hline $\begin{array}{l}\text { Curso(s) } \\
\text { Alternativo(s) }\end{array}$ & Nenhum. \\
\hline Observação[ōes] & Nenhuma. \\
\hline
\end{tabular}

Tabela 9.21: Especificação de Caso de Uso - Visualização dos Pedidos de Alteração a Screm Avaliados

Caso de Uso - Cadastro do Resultado da Avaliação de um Pedido de Alteração de um componente

Neste caso de uso, cujo diagrama c especificações são apresentados. respectivamente, na Figura 9.17 c nas Tabelas 9.22 e 9.23, é descrita a atividade de cadastro do resultado da avaliaçāo de um pedido de alteraçāo de um componente.

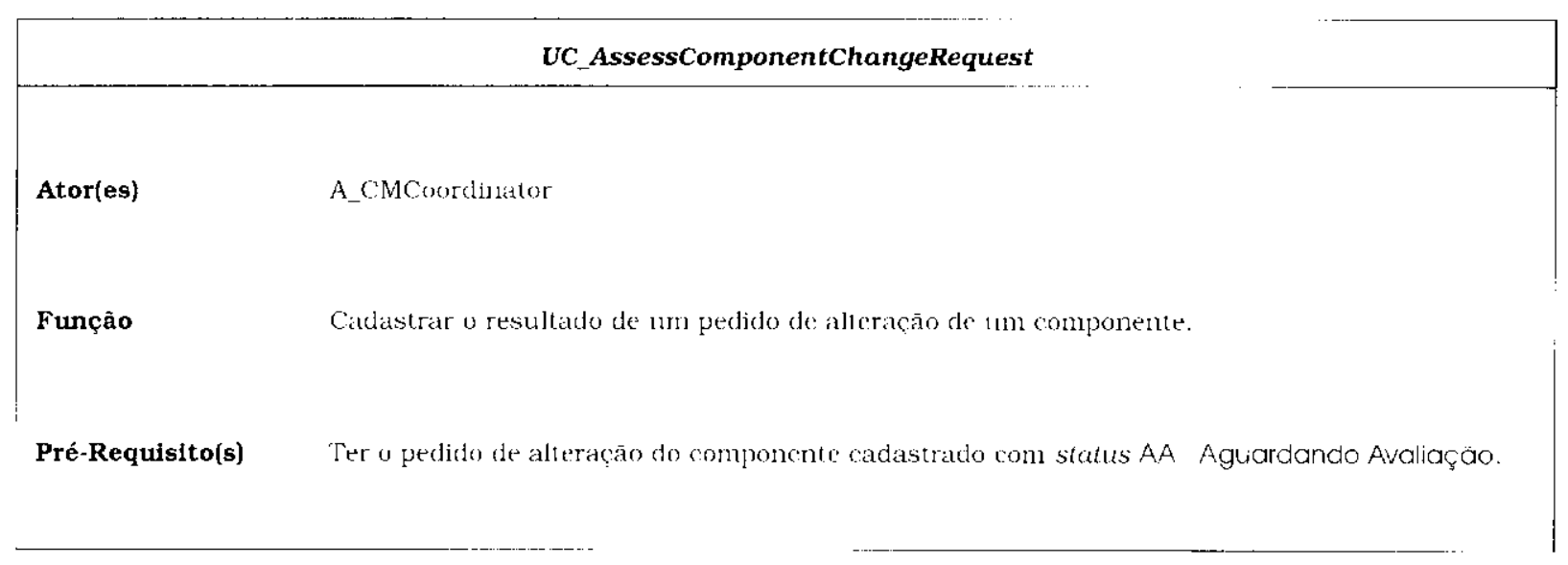

continua na próxina página.. 


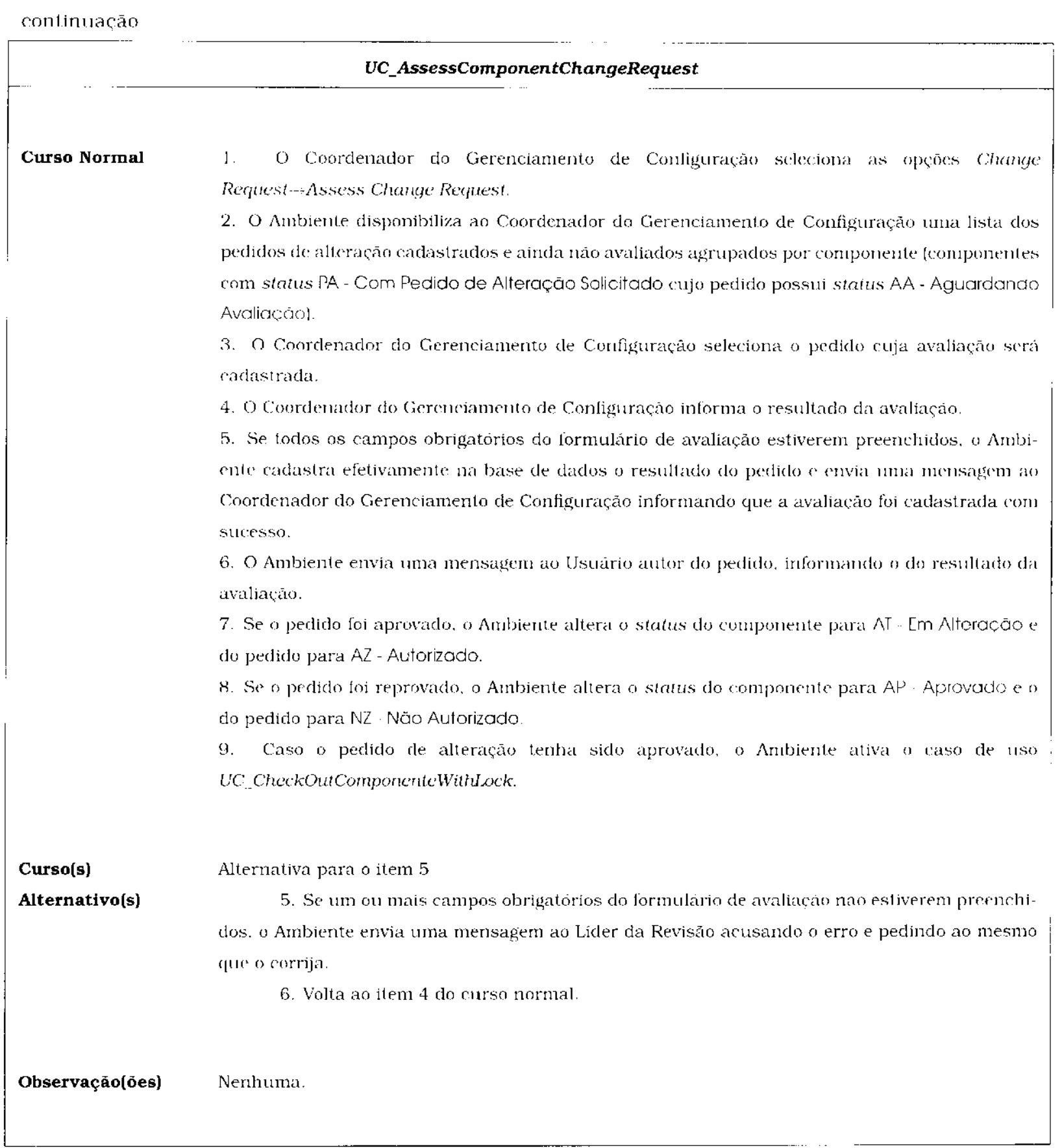

Tabela 9.22: Especilicaçào de Caso de Uso - Cadastro do Resultado da Avaliaçāo de um Pedido de Altcração de um Componente

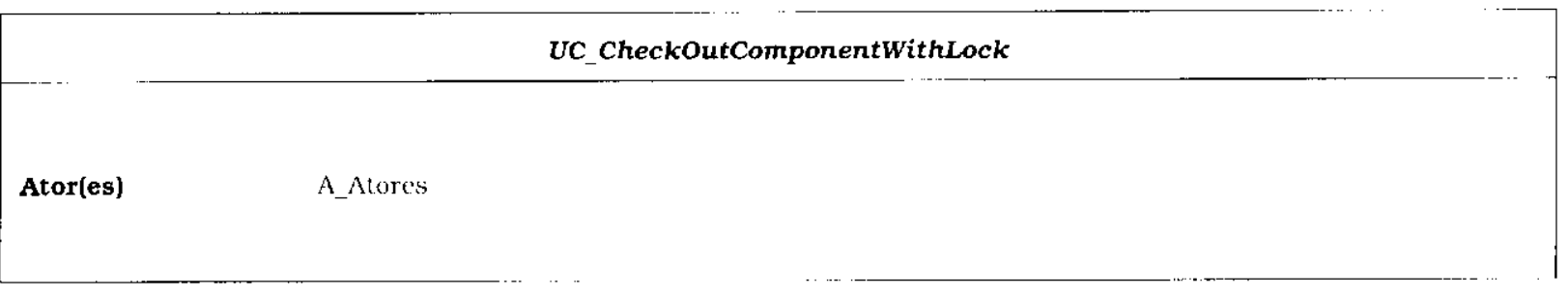

continua na próxima página.. 


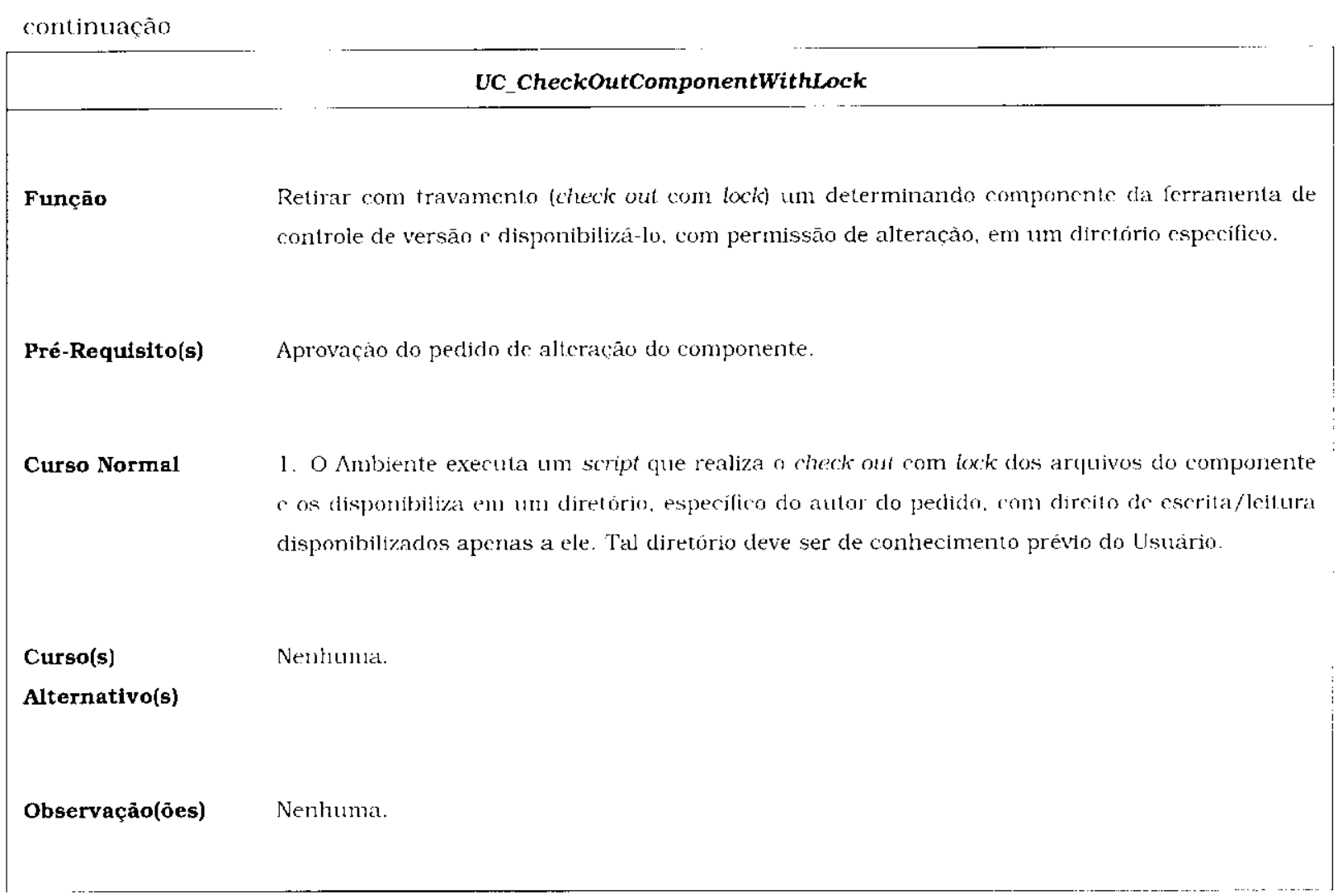

Tabela 9.23: Especificaçāo de Caso de Uso - Disponibilizar um Componente para Alteraçào

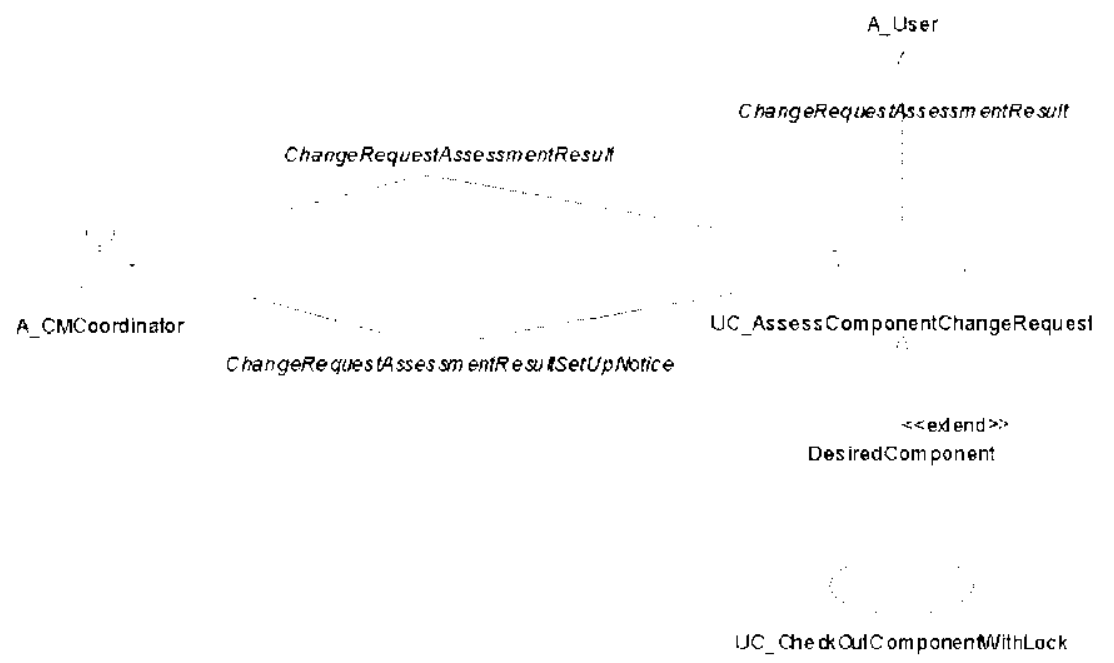

Figura 9.17: Diagrama de Caso de Uso - Cadastro do Resultado da Avaliação de um Pedido de Alteração de um Componentc. 


\section{Caso de Uso - Visualização do Resultado da Avaliação de um Pedido de Alteração}

Ncstc caso de uso. cujo diagrama c especificaçoes são apresentados, respectivamente. na Figura 9.18 e nas Tabelas 9.24 e 9.7, é descrita a atividade de visualização do resultado da avaliação de um pedido de alteraçāo.
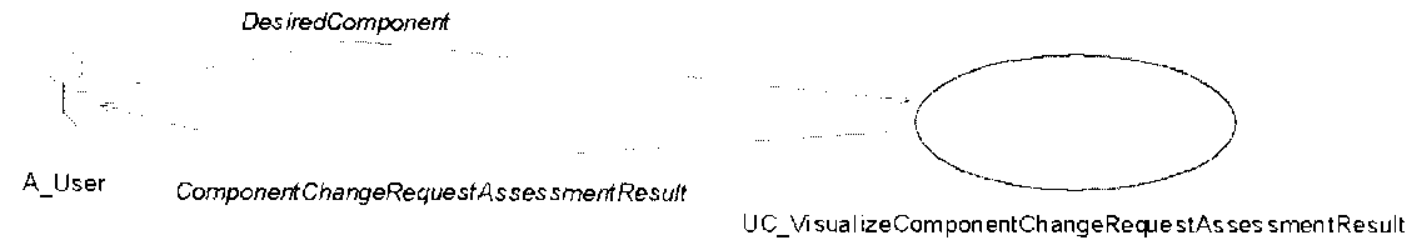

UC_Visual izeComponentChange RequestAs ses sment Result

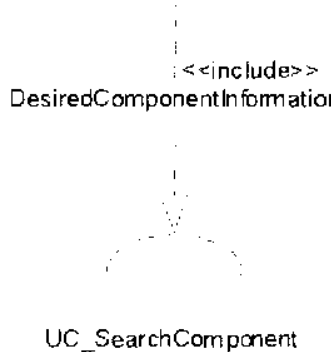

Figura 9.18: Diagrama de Caso de Uso - Visuálização do Resultado da Avaliaçāo de um Pedido de Alteraçào

\begin{tabular}{|c|c|}
\hline & UC VisualizeComponentChangeRequestAssessmentResult \\
\hline Ator(es) & A_User \\
\hline Função & Verificar o resultado da avaliaçáo do pedido de alteraça de um componente. \\
\hline Pré-Requisito(s) & Nenhum. \\
\hline Curso Normal & 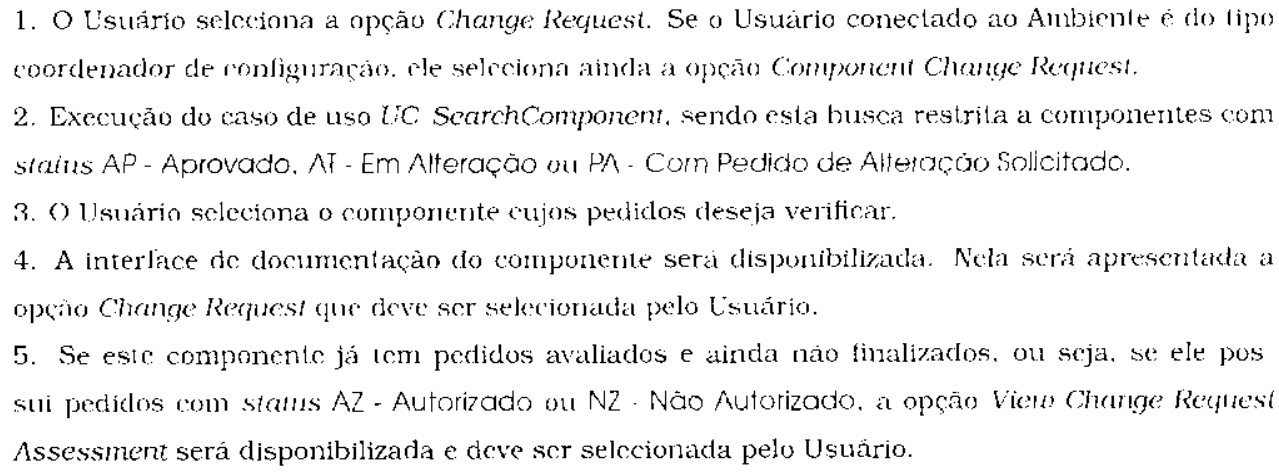 \\
\hline
\end{tabular}

continua na próxima păginá. 


\begin{tabular}{|c|c|}
\hline & UC_VisualizeComponentChangeRequestAssessmentResult \\
\hline Curso Normal & $\begin{array}{l}\text { 6. O Ambiente disponibiliza umá lista contendo os pedidos de alteraçao do componente selecio- } \\
\text { nado que já foram avaliados c ainda nâo foram finalizados (pedidos com status AZ ou NZ). } \\
\text { 7. O Usuário seleciona o pedido desejado. } \\
\text { 8. O Anbiente nustra as informaçoes do pedido desejado. incluindo statuse descriçoes. }\end{array}$ \\
\hline $\begin{array}{l}\text { Curso(s) } \\
\text { Alternativo(s) }\end{array}$ & Nenhum. \\
\hline Observaçāo(ōes) & Nenhuma. \\
\hline
\end{tabular}

Tabela 9.24: Especificaçāo de Caso de Uso - Visualizaçāo do Resultado da Avaliação de um Pcdido de Alteraçào

Caso de Uso - Documentação de Alterações em um Componente

Neste caso de uso, cujo diagrama e especificaçōes sảo apresentados. respectivamente, na Figura 9.19 e nas Tabelas 9.25 e 9.7, é descrita a atividade de documentação de alterações em un componente.

\begin{tabular}{|c|c|}
\hline & UC_DocumentComponentChange \\
\hline Ator(es) & $A_{-}$User \\
\hline Função & $\begin{array}{l}\text { Documentar urna alteraço cm um componente e. posteriormente, disponibiliza lo ao processo } \\
\text { de revisáo. }\end{array}$ \\
\hline Pré-Requisito(s) & 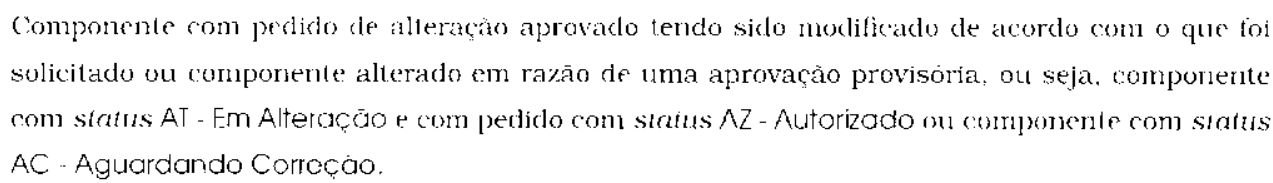 \\
\hline Curso Normal & 1. O Lisuário seleciona as opçoos Document Component +New Version. \\
\hline
\end{tabular}

continua na proxima página.. 


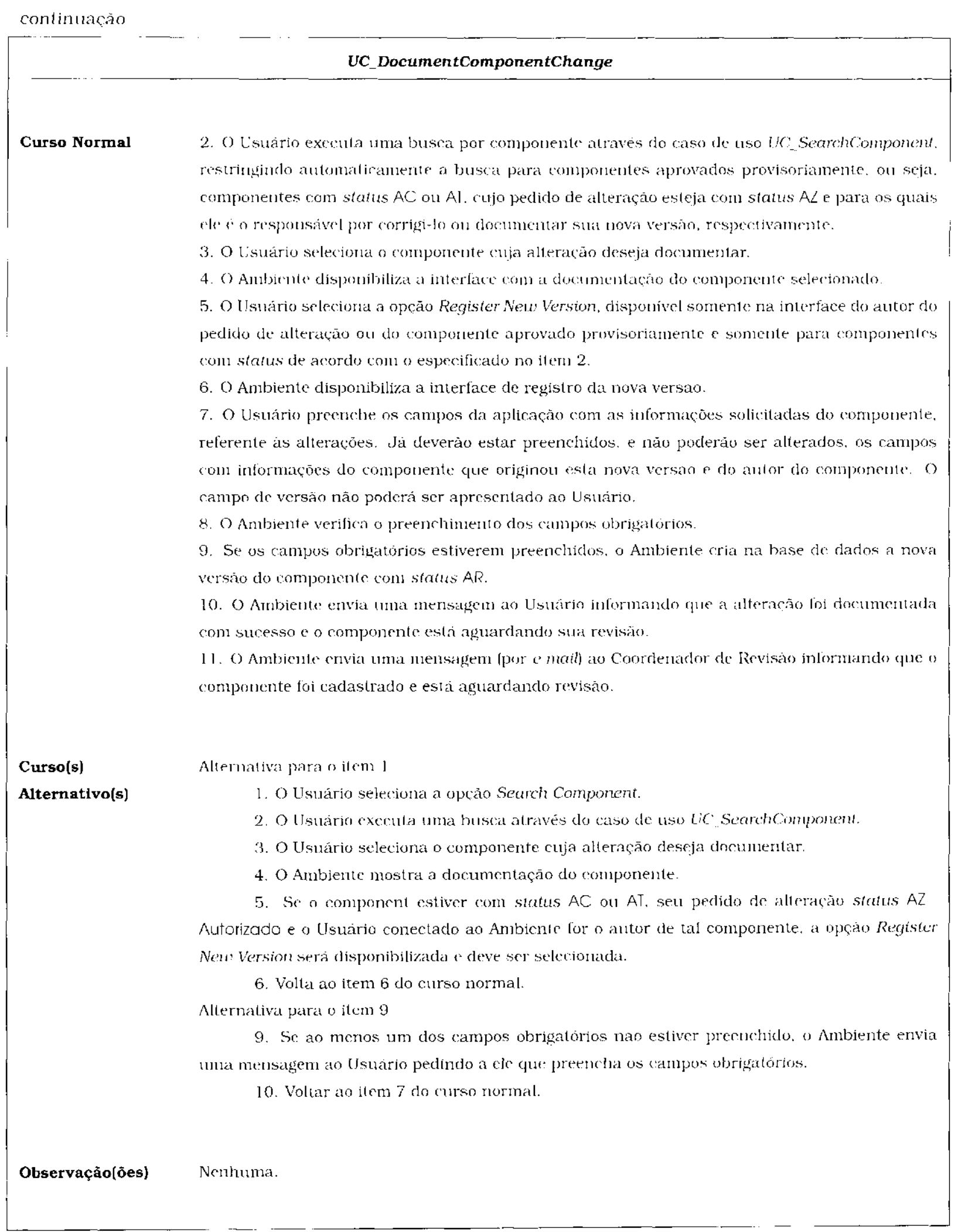

Tabela 9.25: Especificação de Caso de Uso - Documentação de Alteraçôes cm um Com. ponente 


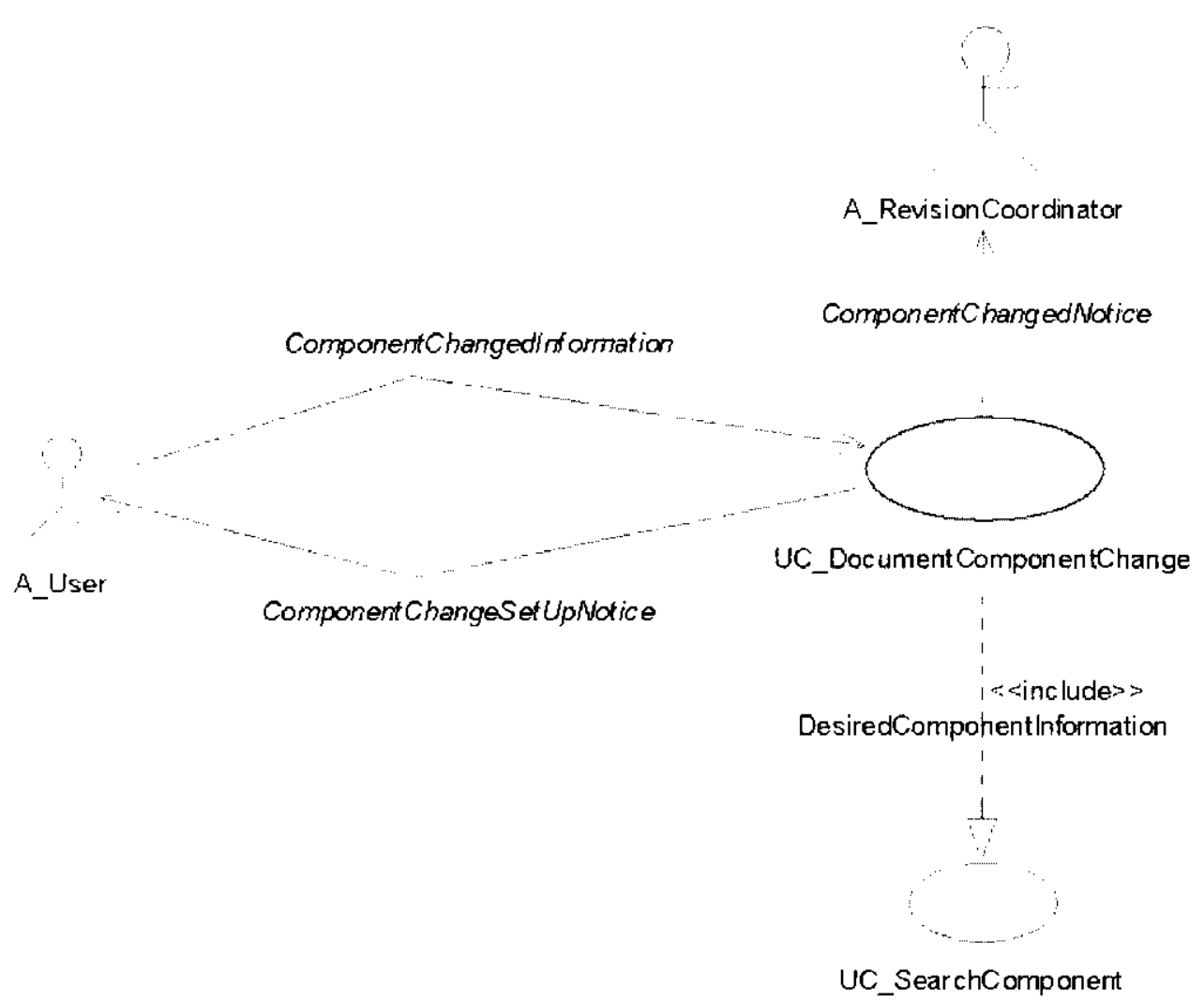

Figura 9.19: Diagrama de Caso de Uso - Documentação de Alteraçōes em um Componente

Caso de Uso - Visualização de Relatórios

Neste caso de uso, cujo diagrama e especificação são aprescntados, respectivamente, na Figura 9.20 e na Tabela 9.26. é descrita a atividade de visualização de relatórios.

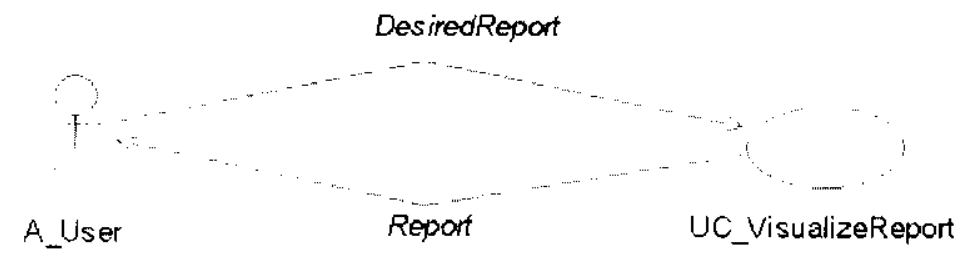

Figura 9.20: Diagrama de Caso de Uso - Visualização de Relatórios

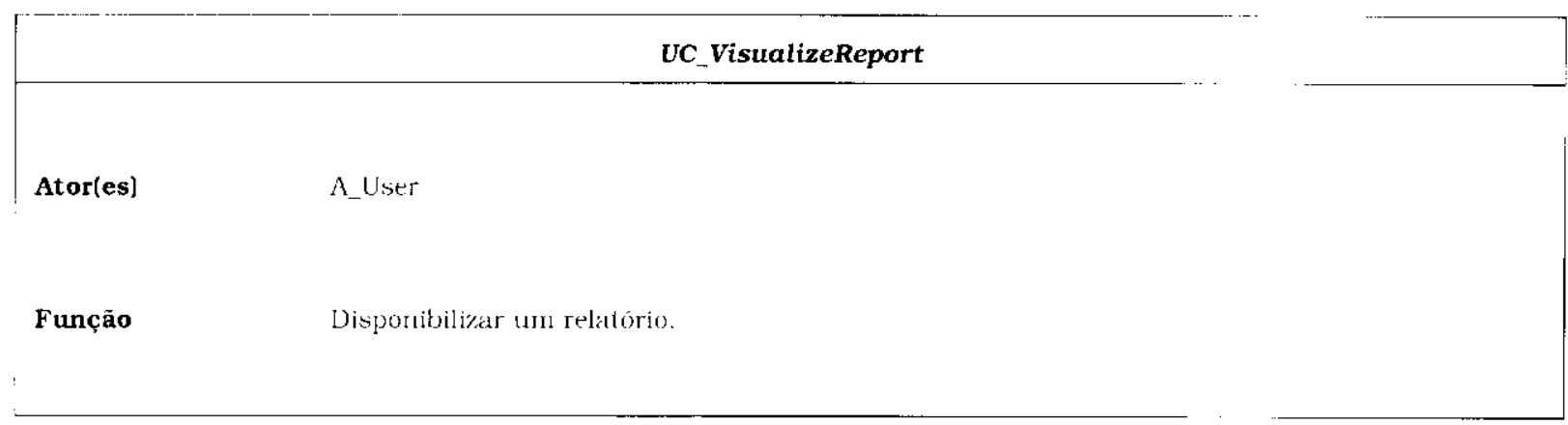

continua rla próxima página.. 


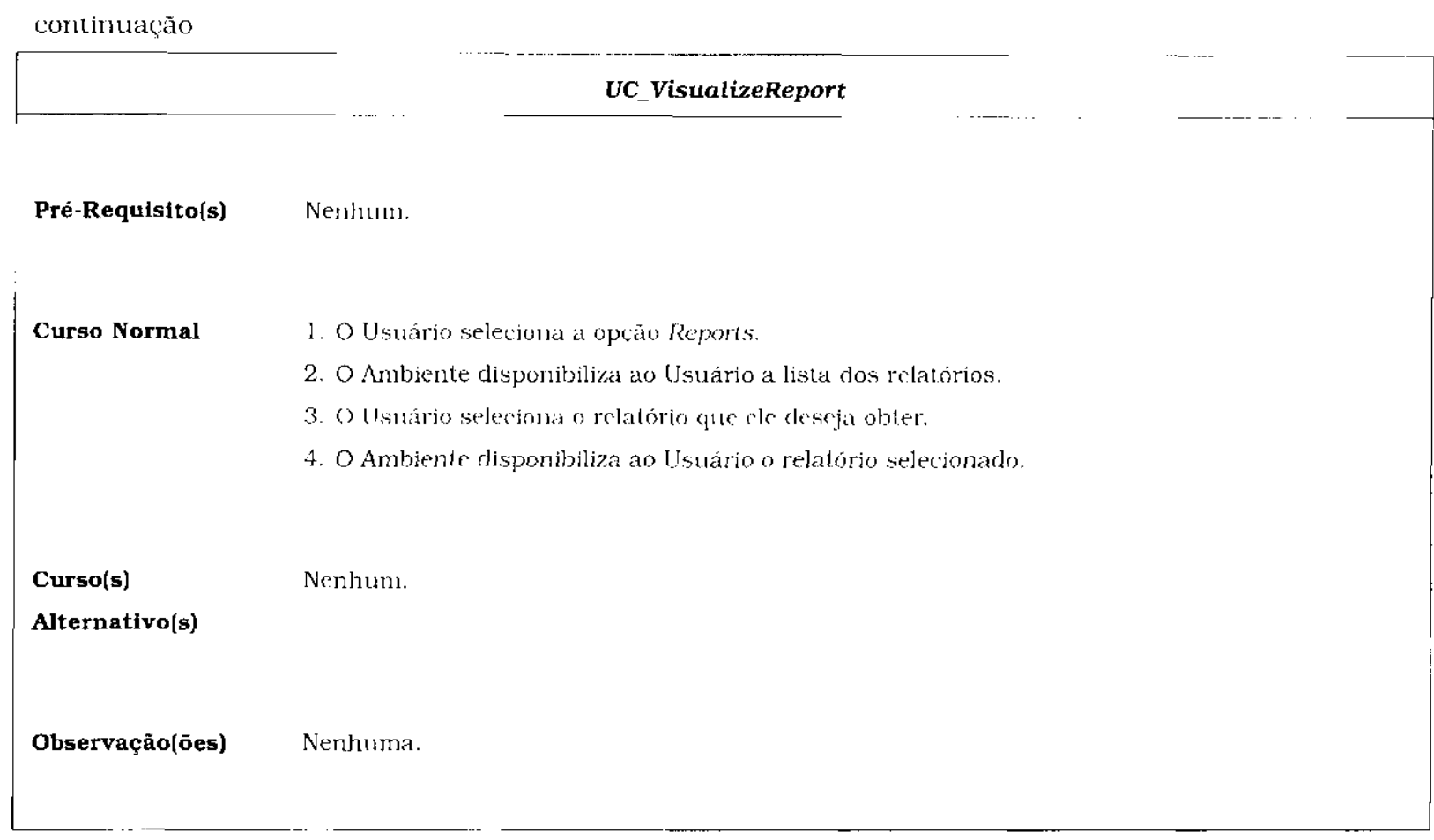

Tabela 9.26: Especificaçào de Caso de Uso - Visualizaçāo de Relatórios

\subsubsection{Diagramas das Classes de Dominio}

O produto da fase de engenharia de requisitos no ambito da perspectiva estrutural. segundo o ProDes/UML, é o diagrama de classes do dominio. Neste diagrama sāo representados os conceitos (ou classes) existentes no dominio do problema, scus atributos e relacionamentos, incluindo agregaçāo. especializaçăo/generalizaçāo e cardinalidade de relaçöes. Vale ressaltar, no cntanto, que é válido ter classes sem atributos ou classes que têm uma função puramente comportamental no dominio ao invćs de uma funçāo informativa. Por modelar o domínio da aplicação, as associaçōes (relacionamentos) não têm direção de navegação e as classes não possuem operaçōes.

Nesta scção, os diagramas que representam os conceitos e rclaçōes do dominio serāo aprescntados. Em razāo da complexidade visual decorrente do número de classes envolvidas, o conteúdo dos diagramas foi selccionado com base em contextos, gerando assim diversas visōes do conjunto total de classes.

Visão Usuário

Os usuários, representados pelas classes User, CMCoordinator, RevisionCoordinator, Reviewer e RevisionLeader, são descritos pelos atributos nome, e-mail, username e senha. 
Cada usuário do sistema deverá ainda ter especificada a sua área de trabalho, ou seja. o dominio do qual o mesmo tem conhecimento. As áreas de trabalho para ele cadastradas serão as que ele poderá atuar como rcvisor. Para estas áreas de trabalho, representadas pela classe WorkArea. as seguintes informaçōes serão mantidas: nome, simbolo c descrição.

Devem ser especificados também os papéis que um usuário pode exercer. Tal informação foi representada através da hierarquia de especialização/generalizaçāo. Vale ressaltar que esta hierarquia foi classificada como incomplete c overlapping. Fisicamente, esta classificação significa, respectivamente, que uma instância da classe de generalização não precisa ser uma instancia de uma classe de especialização e que uma instância da classe de especializaçāo pode ser simultaneamente uma instància de uma outra classe de especializaçāo do conjunto.

As informaçôes referentes aos papéis dos usuários devem ser utilizadas pelo ambiente para identificar quais funçōes devem ser disponibilizadas a cle. Assim, ć preciso que sejam listadas quais funçōes devem ser habilitadas a cada tipo de usuário:

- Usuários Simples: busca de componentes, obtenção do componente c da sua docu mentação, cadastro e cancelamento de componentes do tipo "em desenvolvimento", cadastro de novos componentes, cadastro de novas versōes, cadastro de pedido de. alteraçāo. verificação do status deste pedido e obtenção de relatónios;

- Revisores: funçóes dos usuários simples acrescidos da lista de componentes que eles devem revisar;

- Lider de Revisão: funções dos usuários simples acrescidos da listá de componentes que cle deve revisar. da lista dos componentes para os quais ele deve agendar a reunião de revisão e da lista dos componentes para os quais cle deve cadastrar o resultado da avaliaçào:

- Coordenador de Revisão: funçōes dos revisores (caso cle também seja um revisor), alem da função de distribuição das revisòes aos revisores e de seleção, para cada uma delas, do líder de revisāo:

- Coordenador da Configuração: funçōes do coordenador da revisão, se ele também exercer este papel, além da lista de pedidos de alteraçāo a avaliar. dá função de cadastro do resultado destas avaliaçōes e da funçào de cadastro de novos usuários e áreas de trabalho. Funções como inserção e obtenção de componentes na ferramenta de controle de versōes (CVS) devem ser automatizadas. 
Na Figura 9.21 ć apresentado o diagrama de classes da visāo Usuário.

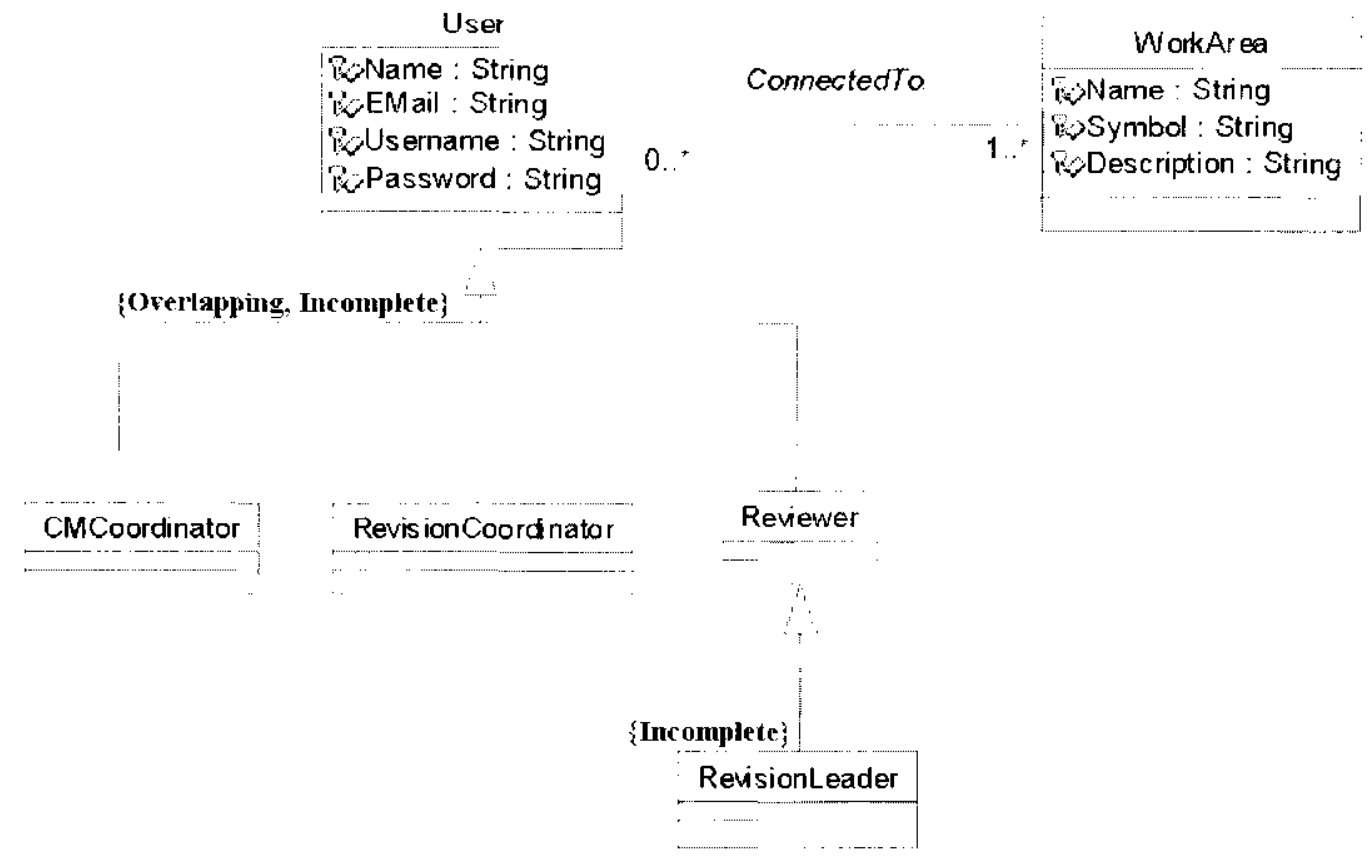

Figura 9.21: Diagrama de Classes - Visão Usuário

Vale ressaltar que, segundo o que foi considerado nesta especificação, deverá existir somente um usuário cadastrado como coordenador da revisão e um usuário cadastrado como coordenador da configuração. Esta restriçāo não impedc, no entanto. que o mesmo usuário assuma ambas as funçōes.

\section{Visão Componente}

Logicamentc, existem três tipos de componentes: $\mathrm{cm}$ desenvolvimento, novos componentes e versões de componentes. No entanto, fisicamente, estes très tipos são representados por apenas duas classes: DevelopingComponent, que representa o primeiro tipo, e Component. que representa o segundo e terceiro tipo.

Os componentes do tipo "em desenvolvimento", representados pcla classe DevelopingComponent, deverāo ter associados a eles as seguintes informaçōes: nome, descrição, data de início do desenvolvimento. data para previsāo de término, status (DV - Em Desenvolvimento. AV - Em Avaliaçāo, CC - Cancelado. FN - Finalizado) c autores.

$\dot{E}$ importante salicntar que componentes do tipo "em descnvolvimento" tem o único objetivo de informar aos desenvolvedores os trabalhos $\mathrm{cm}$ andamento. Sendo assim, estc tipo de componente nāo possui versōes c, tisicamente, c armazenado em uma classe cspecífica. 
Na Figura 9.22 é aprescntado o diagrama de classe da visão Componentes Em Desenvolvimento.

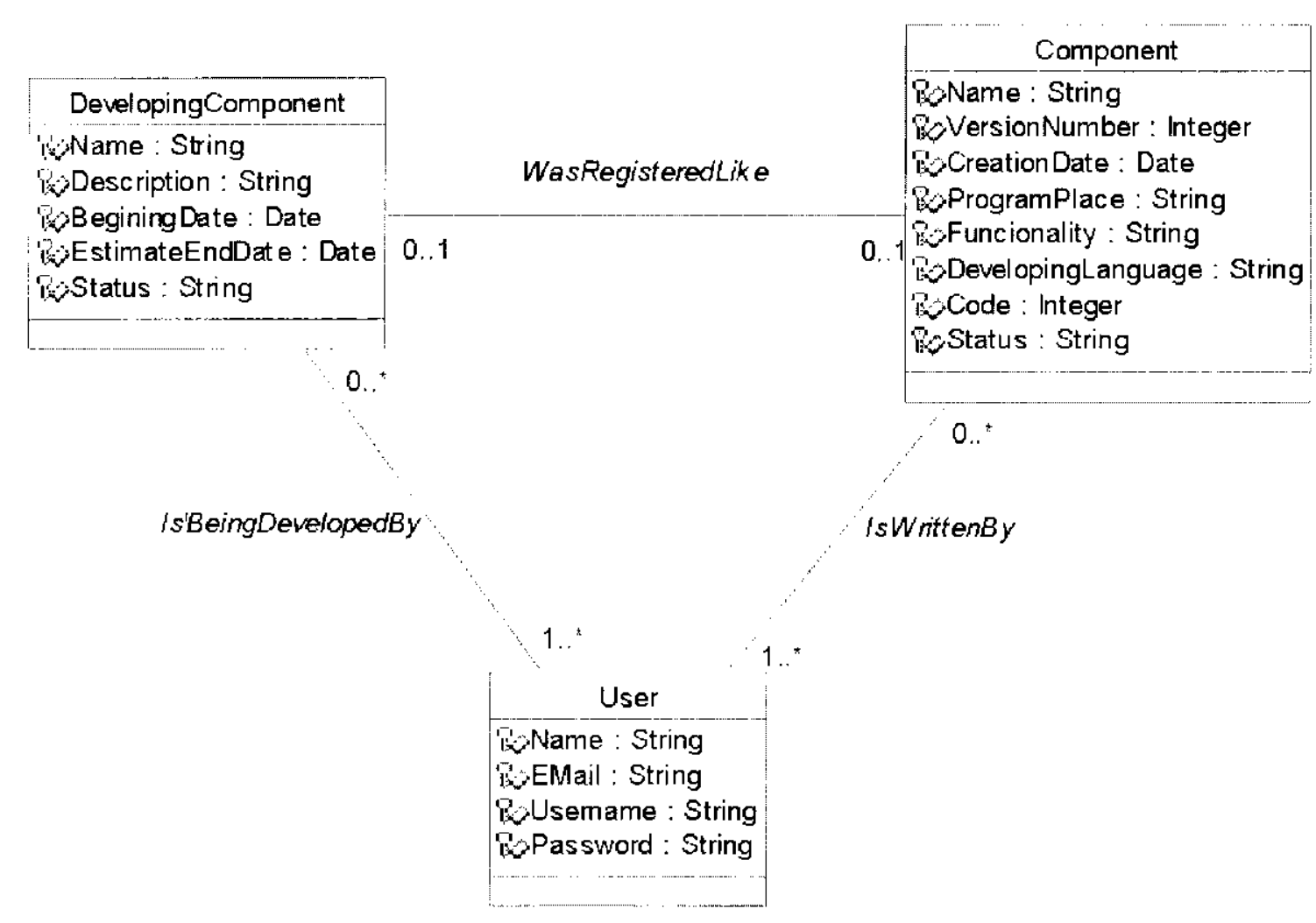

Figura 9.22: Diagrama de Classes - Visão Componentes Em Desenvolvimento

Novos componentes possuem diversos atributos. Entre cles aparecem nome, data de criaçāo, versāo, funcionalidade e status (AR - Aguardando Revisão. AP - Aprovado, RP Reprovado. AC - Aguardando Correção, PA - Com Pedido de Alteraçāo Solicitado ou AT Em Alteraçāo).

O cadastro de novos componentes será também o cadastro de sua documentaçāo. Assim. a classe que trata as informaçoes listadas. Component, está ligada a outras que fornecem informaçōes referentes a sua documentaçào externa. Documentos anexados à documentação externa e o arquivo contendo o código-fonte do componente devem ser disponibilizados. no momento do cadastro do componente, em diretórios especíiticos cujo caminho é o conteúdo dos atributos Place (classe OtherDocuments) e ProgramPlace (classe Component), respectivamente.

A classe Component possui também relaçōes com classes que tratam informaçōes referentes ao componente do tipo "em desenvolvimento" associado, aos revisores de um de- 
terminado componente, ao lider e ao resultado das suas revisōes, e aos scus pedidos de alteraçāo. junto de seus respectivos resultados.

Por envolver diversas classes e inúmcros atributos, nāo sāo listados neste texto todos os relacionamentos e atributos ligados ao conceito de componente. No entanto. informaçoes referentes à documentaçāo externa podem ser encontradas nas Figuras 9.23, 9.24 e 9.25. As outras classes relacionadas à classe Component têm suas informaçōes apresentadas em diagramas de outras visões. como a visão Rcvisão, por cxcmplo.

Por serem representados pela mesma classe, o cadastro de novas versóes para um componente é semelhante ao cadastro de novos componentes, exceto pelo fato de quc esta funcionalidade somente deverá estar liberada para componentes com status em alteraçāo ou aprovado provisoriamente.

Para facilitar o cadastro de novas versōes, informaçōes invariantes como o nome, por exemplo, devem ser automaticamentc preenchidas pclo ambicnte $\mathrm{e}$ não devem ter a sua alteração permitida.

Para facilitar a visualização do diagrama de classes que apresenta o componente, todas as classes dele derivadas e os relacionamentos entre clas, é apresentado um diagrama completo na Figura 9.23 e dois diagramas, ilustrados nas Figuras 9.24 e 9.25. nos quais estão presentes conjuntos de classes, seus atributos c relacionamentos. Vale ressaltar que todos estes diagramas estarāo contemplando apenas a visảo Componente, ou seja. as classes necessárias para documentação externa do componente. É importante notar que, para facilitar a leitura e compreensăo dos diagramas. a disposicão das classes nas Figuras 9.24 e 9.25 c semclhante à disposição das mesmas na Fiğura 9.23.

\section{Visão Revisão}

Todos os componentes deverāo, em algum momento, passar pelo processo de verificação, realizado através de revisöes técnicas formais. O resultado desta avaliação é manipulado pela classe Revision que é descrita pelos atributos: dala, hora, local, resultado. descrição do result ado e código. Alèm disso, informaçōes como revisores, líder da revisão e componente. revisado são mantidas através dos relacionamentos que esta classc possui.

Na Figura 9.26 c apresentado o diagrama de classes segundo a Visāo Revisäo. Vale lembrar que classes relacionadas à documentaçāo do componente năo sào apresentadas en muitos dos diagramas nos quais aparece a classe Component apenas para facilitar a leitura e comprecnsão dos mesmos. 


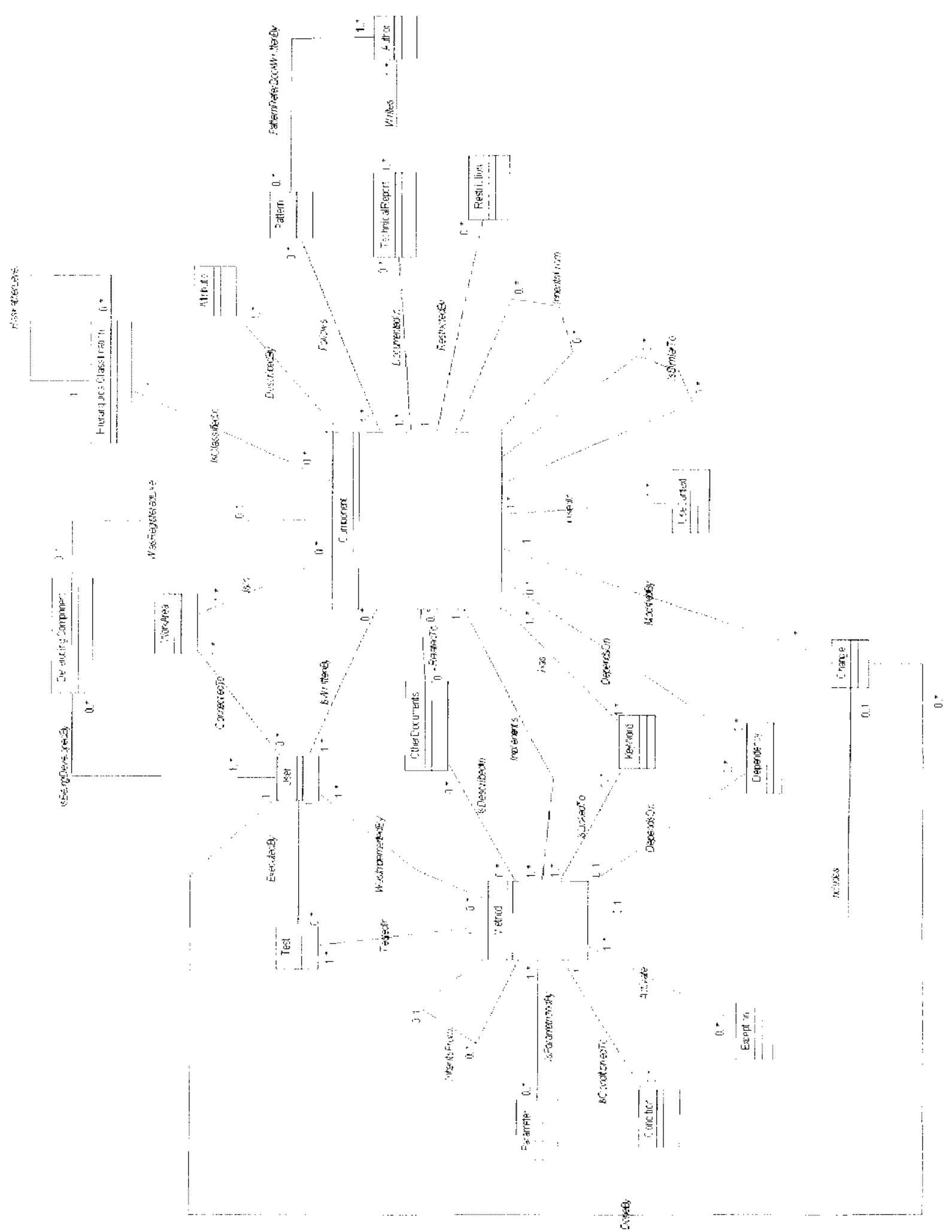

Figura 9.23: Diagrama de Classes - Visão Componentes (Documentação) 


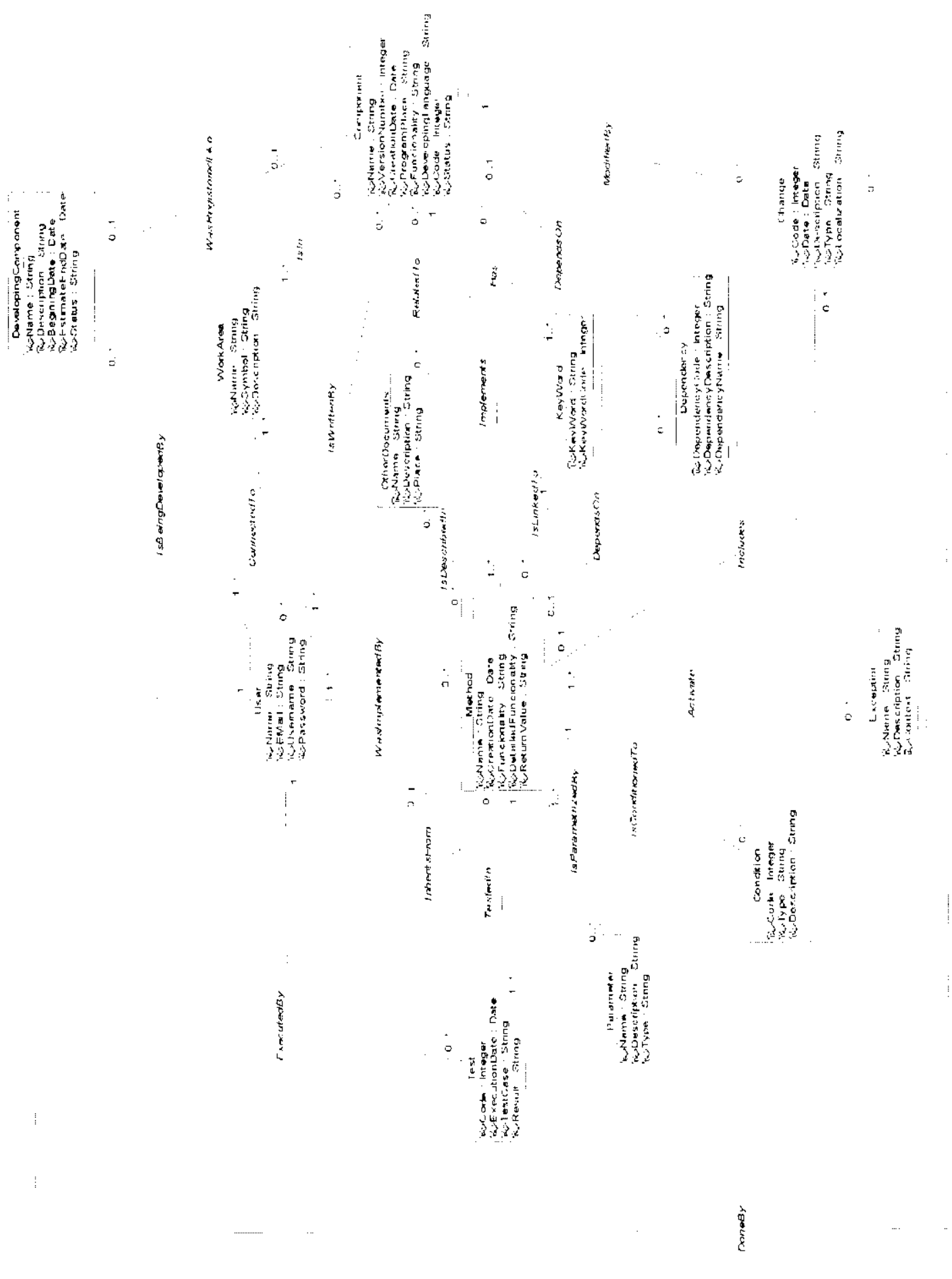

Figura 9.24: Diagrama de Classes - Visão Componentes - Primeira Parte 


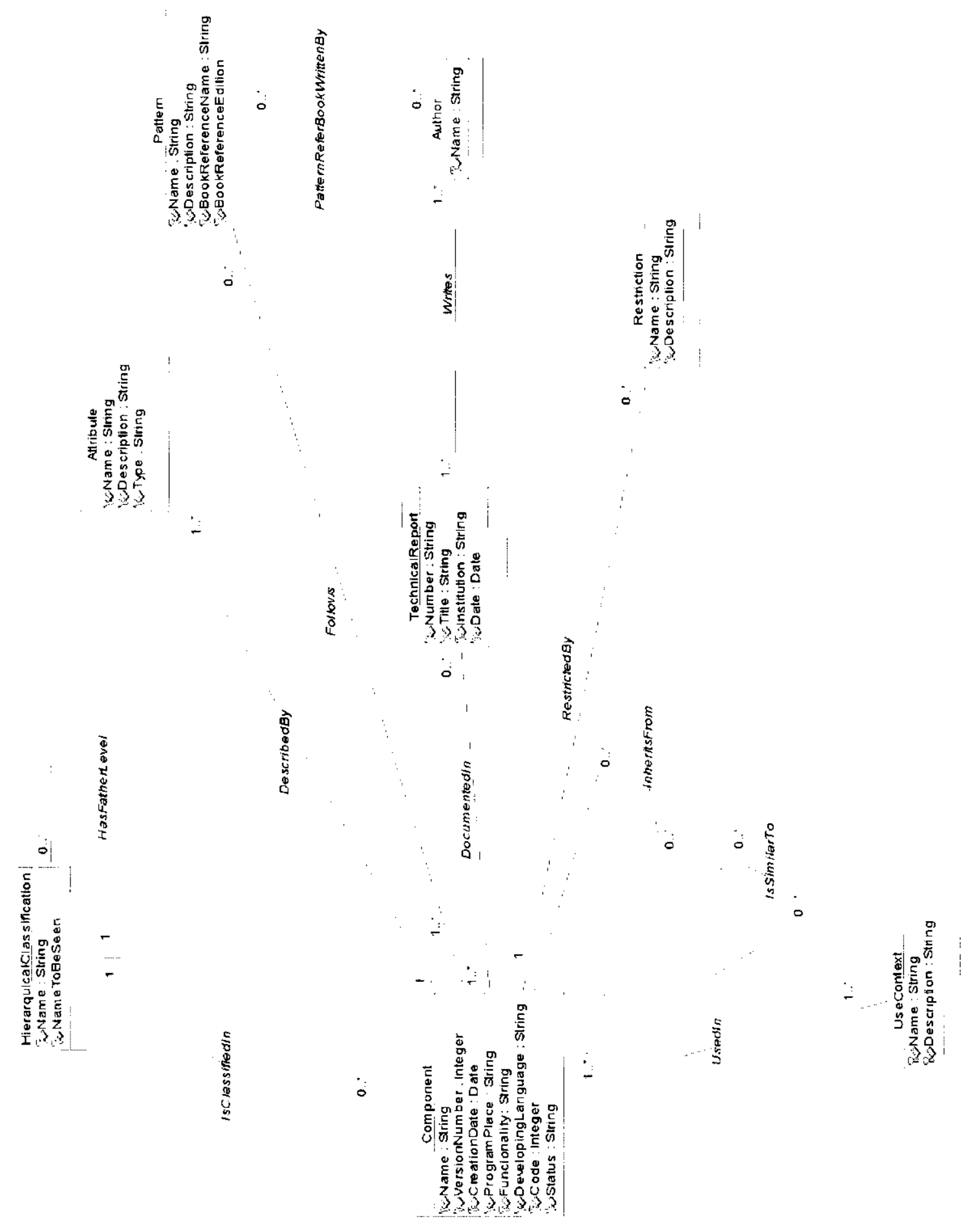

Figura 9.25: Diagrama de Classes - Visão Componentes - Segunda Parte 


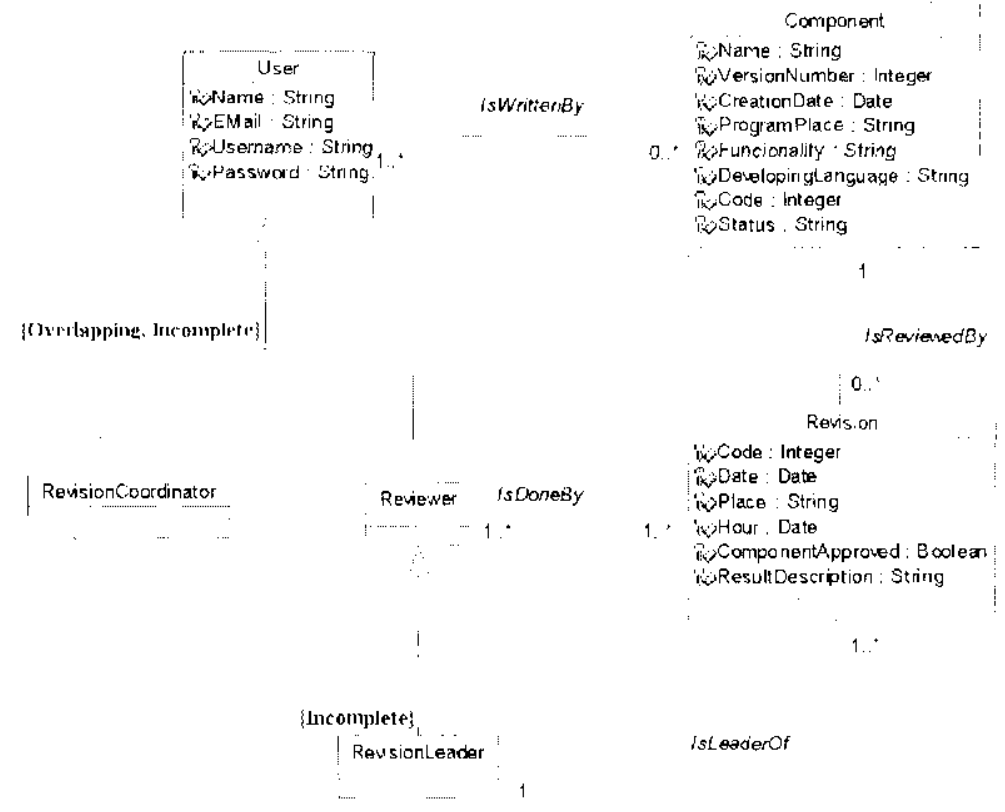

Figura 9.26: Diagrama de Classes - Visāo Rcvisāo 


\section{Visão Pedido de Alteração}

Pedidos de altcraçāo devem ser solicitados sempre que um descnvolvedor desejar alterar um componente. As informaçōes referentes aos pedidos sāo manipuladas pela classe ChangeRequest através dos seguintes atributos: data, motivo, lugar c rcsultado da alteração. Esta classe possui ainda relaçōes com as classes Compontent. User e CMCoordinator. através das quais informaçōes referentes ao componcnte (nome c versão) que se deseja alterar, ao autor do pedido c ao avaliador do pedido são mantidas.

Na Figura 9.27 é apresentado o diagrama de classes da visāo Pedido de Alteraçāo.

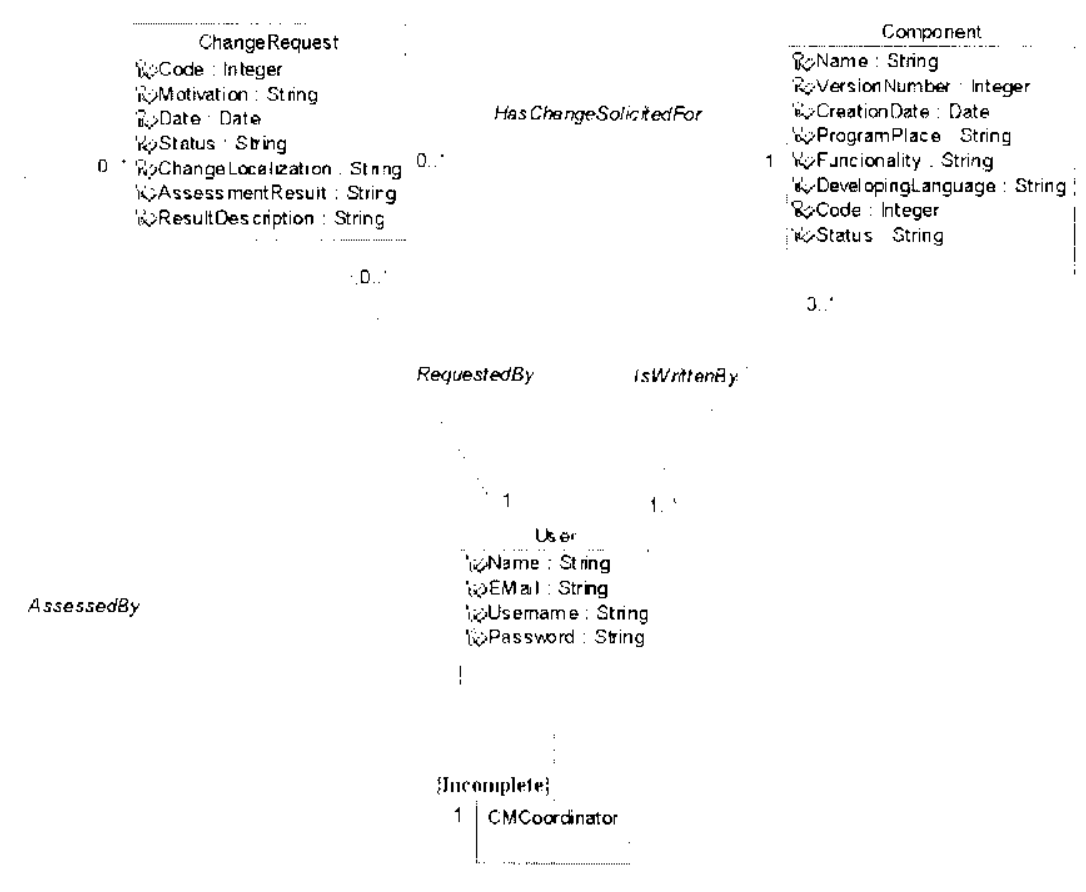

Figura 9.27: Diagrama de Classes - Visão Pedido de Alteraçāo

\subsection{Considerações Finais}

Neste capitulo foi aprescntada a especificação de um ambiente que automatiza algumas das funcoes referentes ao gerenciamento e armazenamento de componentes propostas no capitulo anterior, o RaCooMN.

Para firralizar esta dissertaça, sāo apresentadas no capitulo a seguir algumas consideracoocs e conclusōes sobre o trabalho que foi desenvolvido. 


\section{Capítulo 10}

\section{Conclusões e Trabalhos Futuros}

Por muitos anos, as organizações têm desenvolvido seus sistcmas num ambiente caótico, caracterizado por estimativas de prazos c custos extrapoladas, software sem qualidade e scm manutenibilidade, entre outros problemas. Porem, a crescente demanda por sisıcmas e a compelitividade presente na atual configuraçāo do mercado têm mostrado às organizações as vantagens de um desenvolvimento com qualidade.

Por essa razāo muitas organizações vêm investindo $\mathrm{cm}$ soluçōes tecnológicas que aumentem a qualidade tanto do processo de descnvolvimento quanto de seu software produto.

O reuso tem sido almejado por diversas organizaçōes como umá destas possiveis soluçōes, já que, cono citado anteriormente, "pode ser visto como uma maneira bastante eficaz para aumentar os indices de produtividade, qualidade, confiabilidade, consistência e padronizaçāo do processo de desenvolvimento de software" (de Sá, Werner, \& Goldman 1997).

Entretanto, para a concretização de sua prática cfetiva, o reúso vêm enfrentando barrci ras de diversas origens, tais como questōes técnicas e culturais (Boeing. IBM, \& Paramax 1993). Para auxiliar as organizaçoes a transporem estas diversas barreiras, foi desenvolvida, neste mestrado, uma estratégia para implantação do reúso no processo de desenvolvimento de software das organizaçōes.

A essência dessa estratégia consiste na introdução integrada, gradativa e continua de pequenas alteraçōes no processo de desenvolvimento de soflware. Além disso, através dela, pode-se, entre outras coisas, utilizar o conhecimento obtido na concretizaçăo de um pequeno objetivo para o alcance do proximo, e assim por diante. 
Um outro aspecto importante da filosofia dessa estratégia recai sobre o fato de objetivar, em última instância, a implantaçāo das melhores práticas propostas pela comunidade de Engenharia de Software, descritas na norma NBR ISO/IEC 12207.

Para criar e validar essa estrategia, e identificar os processos a serem abordados pri mordialmente por uma organização que deseja implantar o reúso no seu processo de desenvolvimento de software, foi realizado um estudo de caso. Tal trabalho foi desenvolvido no LABIC (Laboratório de Inteligência Computacional do Instituto de Cièncias Matemáticas e de Computaçāo da Universidade de São Paulo. campus de São Carlos) com o objetivo de viabilizar c implantar o reúso do código-fonte produzido pelos pesquisadores relacionados à área de Extraçào de Conhecimento de Bases de Dados. Por associar os objetivos c neces sidades deste projeto de mestrado aos do LABIC, acredita-se que este estudo de caso tenha trazido contribuiçōes significativas tanto para a área de Engenenharia de Softuare como para o LABIC. A partir de uma série de discussões a respeito da teoria divulgada na literatura de Engenharia de Software confrontada com a realidade do LABIC, cujas necessidades e restriçōes são bastante semelhantes às de muitas organizaçōes de descnvolvimento de soft ware, foram selecionados alguns processos considerados, pelo grupo de trabalho envolvido no estudo de caso. como essenciais para a viabilização do reúso de componentes. São eles: Documentacāo. Verificaçòo e Gerència de Configuraçào de Software.

A necessidade de uma boa documentaçāo é decorrente da sua importancia, utilidade no processo de classificação, avaliação, recuperação e uso de componentes, atividades básicas no processo de desenvolvimento de software baseado no reúso.

O reúso de componentes tem trazido ainda novas demandas relacionadas à garantia da funcionalidade e qualidade dos mesmos, visto que tais caractcristicas são requisitos importantes para que esta atividade atinja os objetivos esperados (Wallin 2002). Assim, requisitos mínimos de qualidade são exigidos dos componentes antes da sua disponibilização no repositório. $\Lambda$ verificaçào ć uma atividade importante nesta direção já que visa garantir aos desenvolvedores que irāo reutilizar um componente que este atende aos requisitos $c$ padrōes para cle estabelecidos. Esta padronização é também importante para facilitar o entendimento e uso dos componentes.

Como citado anteriomente, a cxistencia de una documentação de boa qualidade é muito importante para diversas atividades do processo de desenvolvimento de softuare baseado no reuiso de componentes. Tal documentaçāo, alèm dos próprios componentes, sāo alvo contínuo de mudanças durante o desenvolvimento de software. Porém, quando es tas mudanças não são analisadas previamente. registradas e reportadas aos que precisam 
conhecè-las, o processo de construçāo do software pode tornar-se caótico. Neste contexto. o processo de gerência da configuracào de software, cujo objetivo é coordenar o desenvolvimento de software de maneira a minimizar a confusão gerada pelas constantes alterações nas informaçōes que são por ele produzidas, é de suma importânciáa.

Uma outra questāo a ser considerada é a forma como os componentes scrão armazcnados e disponibilizados aos desenvolvedores, ou seja. o repositório de componentes. Uma fator importante para este repositôrio é que cle mantenha informaçōes e componentes consistentes. Para suprir tais necessidades, foi apresentada também a especificaçāo de um ambiente que, além de armazenar os componentes e suas respectivas documentaçōes, automatiza algumás das atividades do processo de gerenciamento dos componentes proposto na estrátégia, o RaCooMN - Reusable Components Management ENvironment.

\subsection{Liçōes Aprendidas}

Durante a realizaçāo do estudo de caso. algumas dificuldades foram encontradas. principalmente no que diz respeito à conscientização dos participantes da importància das atividades que visam a garantia da qualidade dos componentes desenvolvidos pelos pesquisadores. Embora a iniciativa de implantar o reúso de componentes e, para tanto, implantar tambèm algumas práticas pregadas pela comunidade de Engenharia de Softuare, tenha surgido de uma necessidade levantada pelo laboratório, ainda é significaliva a resistência à aceitaçāo de que não se pode simplesmente "confiar" que o processo e os requisitos definidos serão corretamente seguidos pelos desenvolvedores e que os componentes por cles desenvolvidos têm qualidade por natureza. A partir desta constataçāo, ressalta-se a importancia de o engenheiro de softuare do grupo de trabalho mostrar aos outros integrantes do mesmo as vantagens c os problemas advindos do não seguimento de algumas regras. por mais simples que pareçam, ou pela nāo implantação de uma atividade.

Além disso, notou-se a importância da existência de um patrocinador para a melhoria dentro da organização que deseja implantá-la, papel que nāo deve ser excrcido pelo engenheiro de software. É extremamente importante para o bom andamento do processo de melhoria que o grupo sinta-se motivado e acredite que, ao final dos trabalhos. vantagens serāo obtidas. Para manter tal motivaçāo, além do incentivo do patrocinador, pode-se ter a preocupação em implantar e avaliar, assim que possível, as atividades e requisitos definidos, a fim de que se possa constatar na prática os benefícios alcançados c corrigir possiveis desvios ou problemas que venham ocorrendo. Ao postergar a implantaçāo das atividades corre-se o serio risco de perder a motivaçăo do grupo. No entanto, é impor- 
tante ressaltar que o momento no qual as atividades e requisitos serão implantados devc ser cuidadosamente analisado para que requisitos definidos posteriormente a tal implantaçāo nâo venham a modificar por demais a maneira como estas atividades são realizadas, prejudicando assim a aceitação, o aprendizado e o amadurecimento do novo processo.

\subsection{Contribuiçōes}

As contribuiçōes deste trabalho podem ser resumidas nos seguintes itens:

- a estratégia para auxiliar as organizações a implantar gradativamente e continuamente atividades que viabilizem o reúso de componentes;

- as atividades, e os requisitos minimos para estas atividades, a serem abordadas inicialmente pelas organizaçōes:

- a definição inicial de um processo de descnvolvimento de código-fonte para o LABIC, permitindo que seus pesquisadores produzam códigos padronizados e de maior qualidade, e dediquem-se ao desenvolvimento de novos aplicativos reutilizando códigos anteriores, podendo assim aumentar a sua produtividade acadèmica:

- a especificação de um repositório que automatiza várias das atividades referentes ao armazenamento e gerenciamento dos componentes e suas respectivas documentaçōes.

\subsection{Trabalhos Futuros}

Como continuaçào ao trabalho desenvolvido, sugere-se o desenvolvimento de atividades referentes à avaliaçāo da estratégia, da forma de implantaçāo dos requisitos e dos próprios processos selecionados, visando a melhoria dos mesmos. A partir desta avaliaçà, pode-se trabalhar no sentido de evoluir estas atividades.

Sugere-se também a incorporação, na estratégia, de etapas que visem a manutcnção da motivação do grupo de trabalho.

Guanto ao estudo de caso, para que possa ser concretizada a etapa de implantaçào do processo definido. é preciso que o ambiente para gerenciamento de componentes definido nas reuniões scja implementado. Vale ressaltar que este ambiente possui caracteristicas levemente diferentes do RaCooMN já que está voltado especificamente para o LABIC. Dcpois de executadas estas atividades, deve-se avaliar o processo implantado, incluindo questōes relativas à satisfaçāo e accitação dos pesquisadores, confrontă-lo com às necessidades do 
grupo c, a partir desse resultado, realizar novas "rodadas" no ciclo da estratćgia a fim de otimizar, melhorar tal processo de desenvolvimento.

Com relaçāo ao ambiente proposto nesta dissertaçāo, por ser o objetivo deste trabalho de mestrado apenas a proposta de uma estratégia que facilite a introdução do reúso de componentes no desenvolvimento de softuare, a especificaçāo realizada considcrou apenas os requisitos mais importantes para tal ambiente. Possivclmente, novas funçōes serão incorporadas e outras otimizadas caso sejam realizadas as próximas fases propostas pelo ProDes/UML. Porém, neste momento, alguns fatores são pcrceptiveis e podem ser ressaltados:

- Pode-se implementar o registro do reúso de um componente, ou seja, uma função que permita a confecçāo de um relatório informando que um determinado componente foi reutilizado por uma determinada pessoa (ou que esta tentou fazê-lo). Com isto, podcse facilitar o cálculo do ganho real obtido com o reúso do componente e aumentar a reusabilidade do mesmo por manter junto à sua documentação a experiência dos esforços para reutilizá-lo. Entre as informaçōes importantes para esta documentaçào estào a descriçāo do ambiente de reúso, os problemas encontrados. especialmente na compreensāo, integraçào c adaptaçāo do componente, e quanto esta atividade foi custosa:

- Com o registro das pessoas que reutilizaram um componente, pode-se implementar uma funça para informá-las quando novas versöes do componente forcm aprovadas. Esta comunicaçào, de acordo com as funçōes atualmente modeladas, é de responsabilidade do usuário, ou seja, cabe a ele buscar periodicamente por novas versōes do componente. UJma opçāo bastantc simples. considerando a modelagem atual. é a implementação de uma rotina que, periodicamente, extraisse um relatório com os componentes atualizados e os enviasse, automaticamente, por e-mail aos usuários cadastrados no sistema. Lsta opçāo, no entanto, tem seus pontos fortes e fracos, podendo servir tanto como forma de comunicação quanto como forma de aborrccimento aos usuários:

- Conforme o número de componentes armazenados for aumentando, os métodos utilizados para recuperação podem nāo mais ser eficientes, sendo necessária a implementaçào de técnicas mais robustas: 
- Podc-sc implementar uma maneira de os usuários avaliarem os componentes, de preferència justificando sua posição. Esta avaliaçāo pode ser realizada através do preenchimento de um formulário. da atribuição de notas, entrc outras formas, e pode ser utilizada como fator para restriçāo da busca, para seleçāo ou rejeição de um componentc em uma determinada seleção, para permancencia do mesmo no repositório. entre outras atividades

- Da mancira como foi modelado, o ambiente nāo permite que scjam registradas versōes reutilizáveis de um componente a partir de outra versāo que nāo a mais recente, ou scja, nāo é possível a existència de ramificaçoes a partir de qualquer versāo. Este fato se deve ao uso das ramificaçōes para armazenamento, na ferramenta de controle de versōes, de versōes que não foram totalmente aprovadas. Em razão da existencia de ramificaçōes não ser essencial ao uso do ambiente, optou-se por mantê-lo como foi inicialmcnte projetado. Além disso, deve-se ressaltar que somente o registro das ramificaçōes como tal não é possivel, e que os usuários podem criâ-las e armazená-las como um outro componente, como versōes do tronco, ou simplesmente não armazenálas no ambiente, embora nenhuma destas opções seja recomendável, exceto em casos esporádicos e justificados. 


\section{Referências Bibliográficas e Bibliografia}

Ambriola, V.. L. Bendix, \& P. Ciancarini (1990). The evolution of configuration manage ment and version control. IEE Software Engineering Journal 5(6), 303-310.

Andexcr. J. (1998). Design guidelines and documentation paradigms for object oriented programs. Dissertação de Mestrado. McMaster University, I Iamilton, Ontário. Canadá.

Baranauskas, J. A. \& G. E. A. P. A. Batista (2000). O projeto Discover: Idćias iniciais (comunicaçāo pessoal).

Baranauskas. J. A. (2001). Extraçāo Automática de Conhecimento por Múltiplos Indutores. Tese de Doutorado. Instituto de Ciências Matenáticas e de Computação. Sào Carlos, São Paulo. Brasil.

Berlack, H. R. (1992). Software Configuration Management. Wiley Series in Soltware En gineering Practice.

Blanqui, F. (1997). A document-centered approach for an open case environment framework connected with the world wide web. Soflware Engineering Note's 22(2), 58-63.

Bocing. IBM. \& Paramax (1993). STARS conceptual framework for reuse processes (CFRP), volume I: Defìnition. versào 3.0. Relatório Técnico STARS VC-A018/001/00, STARS Soft ware Technology for Adaptable Reliable Systems.

Braga. R. M. M., C. M. L. Werner, \& M. Mattoso (1998). A reuse infrastructure based on domain models. Em ICCI 98: 9th International Conference on Computing and Information. páginas $227-234$.

Braga, R. M. M., C. M. L. Werner. \& M. Mattoso (1999). Odyssey: A reuse environment based on domain models. Em Proceedings of IEEE Symposium on Application-Specific Sys terns and Software Engineering Technology (ASSET'99), páginas 49-57. 
Braga, R. M. M., C. M. L. Werner, \& M. Mattoso (2000). Using ontologies for domain information retrieval. Em 11th International Conference on Database and Expert Systems Applications DEX 2000 , páginas 836-840.

Cederquist, P., R. P. D. G. Grubbs, R. Brunskill, K. Dyer, K. Pingle, T. A. Peterson. I. Wallin, D. Koschuetzki, \& M. Brown (1992). Version management with CVS. http://www.cvshome.org.

Cereda, R. L. D. \& J. C. Maldonado (1987), Introduçāo ao FORTRAN 77 para Microcomputadores. Editora McGraw-Hill.

Colanzi, T. E. (1999). Uma abordagem integrada de desenvolvimento e teste de software baseada na UML. Disscrtação de Mestrado. Instituto de Ciências Matemáticas e de Computaçào, São Carlos, São Paulo. Brasil.

Coulange, B. (1998). Software Reuse. Springer-Verlag Londom Limited.

Creps, R. E., M. J. Davis, M. A. Simos. P. Collins, \& M. G. Wickman (1995). Using a conceptual framework for reuse processes as a basis for reuse planning. Em Software Technology Conference.

Creps, R. E.. M. A. Simos, \& R. Prieto-Diaz (1992). The STARS conceptual framework for reuse processes. Em Software Technology for Adaptable Reliable Systems (STARS'92).

Davis, T. (1993). The reuse capability model: a basis for improving an organization's reuse capability. Em Proceedings of the 2nd International Workshop on Software Reuse, páginas 126-133.

da Rocha, A. R. C., J. C. Maldonado, \& K. C. Weber (2001). Qualidade de Software-Teoria e Prática. Prentice-Hall.

de Sá, M. L. B., C. M. L. Werner, \& I. Goldman (1997, Outubro). Introduçāo da reutilizaçāo em uma empresa brasileira de produção de software. Em XI Simpósio Brasileiro de Engenharia de Software, páginas 233-248.

de Sá. M. L. B. (1997). Planejamento para reutilização de software: Um estudo de caso sobre a introduçāo de um programa de reutilizzaçāo cm uma empresa brasileira. Disser Lačão de Mestrado. Universidade Federal do Rio de Janciro. 
de Souza, R. P., M. N. Costa, R. M. M. Braga, M. Matoso, \& C. M. L. Werner (2001). Software components reuse through web search and retrieval. Em International Workshop on Information Integration on the Web Technologies and Applications, päginas 12-18.

Fayyad, U., G. Piatetsky-Shapiro, \& P. Smyth (1996a). Knowledge discovery and data mining: Towards a unifying framework. Em Proceedings of the Second International Conference on Knowledge Discovery and Data Mining.

Fayyad. U., G. Piatetsky-Shapiro, \& P. Smyth (1996b). The KDD process for cxtracting uscful knowledge from volumes of data. Communications of the ACM 39(11), 27-34.

Félix, L. C. M. (1998). Data mining no processo de extraçāo de conhecimento de bases de dados. Dissertação de Mcstrado. Instituto de Ciēncias Matemáticas e de Computação, São Carlos. São Paulo, Brasil.

Fiats, M. I. (2000). Diretrizes para o estabelecimento de melhoria de processo adequada a empresas de pequeno porte. Dissertação de Mestrado, Instituto de Ciências Matemáticas e de Computação, São Carlos, Sào Paulo, Brasil.

Fichman, R. G. \& C. F. Kcmerer (1997). Object technology and reusc: Lessons from early adopters. IEEE Computer Society 30(10), 47-59.

Fowler, M. \& K. Scott (1997). UML Distilled: Applying the Standard Object Modeling Language. Addison-Wesley.

Fowler, M. \& K. Scott (2000). UML Essencial: Um Breve Guia para a Linguagem-Padrāo de Modelagern de Objetos. Bookman.

Freeman, P. (1987). Tutorial: Software Reusability. IEEE Computer Society.

Gamma, E., R. Helm, R. Johnson. \& J. Vlissides (1995). Design Patterns: Elements of Object-Oriented Software. Addison-Wesley.

Geromini, M. R. (2000). Estudo e proposta de uma interface gráfica para o ambiente computacional para extração de conhecimento discover.

Gremba. J. \& C. Myers (1997). The IDE $\Lambda \mathrm{L}$ process model: A practical guide for improvement.

Harper, D. (2001). Wincvs 1.3 - users guide. http://www.cvsgui.org. 
Hilera, J. R.. I. A. González, J. A. Gutiérez, \& J. M. Martinez (1998). Software documentation as an engincering process. Software Engineering Note's 23(5), 61-64.

Holanda, C. B. S., C. A. A. Souza, \& W. L. Mclo (2000). Proreuso, repositorio de componentes para web.

IIolanda, C. B. S., C. A. A. Souza. \& W. L. Melo (2001). Proreuso: Um repositorio de componentes para web dirigido por um processo de reúso. Em XV Simpósio Brasileiro de Engenharia de Software.

IEEE (1998). IEEE Std 828-1998, standard for software configuration management plans Em IEEE Software Engineering Standards Collection - Volume 2: Process Standards.

Jacobson. I., M. Griss, \& P. Jonsson (1997). Making reuse business work. IEEE Computer Society $30(10), 36-42$

Kang, K. C., S. Cohen, R. Holibaugh, J. Perry, \& A. S. Peterson (1992). A reuse-based software development methodology. Relatório l'écnico CMU/SEI-92-SR-4. Software Enginecring Institute.

Karlsson, E.-A. (1995). Softuare Reuse. A Holistic Approach. Editora Wiley.

Lewandowski, G. (2000). Csci 231 code documentation standards. http://www.es.hope.edu/ lewandow/courses/csci231/documentation.html.

Machado. L. F. D. C.. K. M. de Oliveira, \& A. R. C. Rocha (2000. Abril). Modelo para definição de processos de software baseado na ISO/IEC 12207, em modelos de maturidade c caracteristicas do projeto. Em Terceiro Workshop Ibero Americano de Engenharia de Requisitos e Ambientes de Software.

Mcclure, C. (1995). Model-driven software reuse practing reuse information engineering style. http://www.reusability.com/papers2.html.

McFeeley. R. (1996). IDEAL: A userś guide for soltware process improvement. Relatório Técnico CMU/SEI-96-HB-001, Software Enginecring Institute.

Neighbors. J. (1992). The evolution from software components to domain analysis. International Journal of Softuare Engineering and Knowledge Engineering 2(3). 325-354.

OMG (2001). OMG unified modeling language specification - version 1.4. http://www.ong.org/technology/documents/formal/uml_2.htm. 
Pacheco. R. F. (1997). Uma forma de implantaçāo do gerenciamento de configuraçāo de software em empresas de pequeno porte. Dissertaçāo de Mestrado, Instituto de Ciências Matemáticas e de Computaçāo, Sāo Carlos. São Paulo, Brasil.

Parnas. D. L. \& J. Madey (1995). Functional documents for computer systems. Relatório Técnico CRL Report 309. McMaster University.

Perry, J. M., G. R. Affiliate, \& G. G. S. Corporation (1988). Perspective on software reuse. Relatório Técnico CMU/SEI-88-TR-22. Software Engineering Institute.

Phoha. V. A. (1997). A standard for software documentation. IEEE Computer Society $30(10) .97-98$.

Prcssman. R. S. (1994). Software Engineering - A Practitioner's Approach. McGraw-Hill Series in Computer Science.

Pressman. R. S. (1997). Software Engineering - A Practitioner's Approach. McGraw-Hill Series in Computer Seience.

Pressman. R. S. (2001). Soffware Engineering-A Practitioner's Approach. McGraw-Hill Series in Computer Science.

Rine, D. C. (1997). Supporting reuse with object technology. IEEE Computer Society 30(10). 43-45.

Rumbaugh, J., I. Jacobson. \& G. Booch (1999). The Unified Modeling Language Reference Manual. Addison-Wesley.

Schafcr, W., R. Prieto-Díaz, \& M. Matsumoto (1994). Softuare Reusability. Editora Ellis Horwood Limited.

Soares, M. D., R. P. de Mattos Fortes, \& D. de Abreu Moreira (2001). Manual de instruçào da VersionWeb - uma ferramenta que gerencia versões de arquivos através da web. Relatório Técnico 130, Institulo de Cièncias Matemáticas e de Compulaçăo. Sāo Carlos. Sāo Paulo, Brasil

Sun (1999). Java code conventions. http://java.suncom/docs/codeconv

Wallin, C. (2002. January). Verification and validation of components and component based software systems. Relatório técnico, Mälardalen University. 
Werner, C. M. L. \& R. M. M. Braga (2000, Outubro). Desenvolvimento baseado em componentes. Em XIV Simpósio Brasileiro de Engenharia de Software, páginas 297-329.

Yacoub. S., H. Ammar, \& A. Mili (1999). Characterizing a software component. Em International Workshop on Component-Based Software Engeneering.

Yamashiro, F.. L. C. Beraldi, \& R. Sanches (1996). Instruçoes de uso de um sistema de controle de versōes RCS - revision control system. Relatório Técnico 44. Instituto de Cièncias Matemáticas e de Computação, Sảo Carlos, Sảo Paulo, Brasil. 


\section{Apêndice $A$}

\section{Estudo de Caso}

\section{A. 1 O Ambiente do Estudo de Caso}

A cvolução da computaçāo nas últimas décadas permitiu a geração c o armazcnamento de uma grande quantidade de dados. Métodos tradicionais para análise desses dados tèm se tornado caros e lentos devido ao grande volume de informaçōes disponiveis. Nesse contexto, novas tecnologias têm sido estudadas a fim de automatizar o processo de cxtraçāo dos padrões embutidos nos dados, trazendo vantagem competitiva para as organizaçōes que fazem uso deles. Esse ramo de pesquisa ć chamado de Extração de Conhecimento de Bases de Dados (Krouledge Discovery in Database - KDD) (Fayyad, Piatetsky-Shapiro. \& Smyth 1996a).

Por scr uma área de pesquisa relativamente recente, existem poucas ferramentas que suportam o processo como um todo, isto é, que automatizam o processo do inicio ao fim. Esse fato é agravado ainda pela utilizaçāo, por parte das ferramentas, de algoritmos proprictários. limitando o trabalho dos pesquisadores.

Assim, é comum aos pesquisadores, no decorrer dos scus trabalhos, desenvolverem aplicativos que auxiliem seus estudos. Porem, como nuitas vezes os trabalhos destas pessoas náo acontecen de forma integrada, muitos destes aplicativos são desenvolvidos por mais de um pesquisador, sendo esse um dos principais fatores geradores de csforços repetidos, principalmente no que tange à codificação.

Nesse contexto, os pesquisadores de Aprendizado de Máquina (AM) e Daia Mining (DM) do Laboratorio de Inteligência Computacional (LABIC) do Instituto de Ciências Matemáticas e de Computação da USP/Sāo Carlos sentiram-se motivados em desenvolver um ambiente que agrupe um conjunto de ferramentas de mancira intcgrada c padronizada, a fim de 
satisfazer as suas necessidades no que tange às atividades relativas ao processo de Extraçāo de Conhecimento de Bases de Dados. Este ambiente recebeu o titulo de Discover (Baranauskas \& Batista 2000).

O principal objetivo do Discover é fornecer um ambiente integrado e padronizado que suportc as diversas fases do processo de Extração de Conhecimento de Bases de Dados, desde o accsso e preparação dos dados até a avaliaçāo c disponibilização do conhecimento. permitindo um aumento da produtividade dos pesquisadores de AM c DM através da reduçāo da repetitividade no trabalho dos mesmos. Para isto, deve-se permitir que este processo seja apoiado por um conjunto de componentes que devem ser reutilizados pelos pesquisadores que necessitarem da sua funcionalidade. Vale ressaltar que um ponto crucial é que o ambiente seja suficientementc rígido, a fim de garantir a integração dos trabalhos desenvolvidos, c simultancamente flexivel, para garantir que novas pesquisas. projetos e algoritmos sejam facilmente integrados ao ambiente (Baranauskas 2001).

\section{A.1.1 Histórico}

O ambicnte Discover teve inicio quando dois alunos de doutorado do LABIC em conjunto com suas orientadoras constataram que os pesquisadores de AM e DM deste laboratorio estavam desenvolvendo isoladamente código com a mesma funcionalidade. Essa falta de integração cra resultado de uma série de fatores, tais como a falta de documentação e a falta de um rcpositório onde os códigos desenvolvidos ficariam disponiveis.

Surgiu, entāo, a proposta de criar um projeto no qual todos os membros do laboratório com pesquisas relacionadas a $\Lambda \mathrm{M}$ e DM estariam envolvidos - o ambiente Discover. A principio, este projeto consistiria apenas em um repositório de scripts, os quais seriam apenas pequenos programas que realizariam tarefas atômicas. Através do uso de superscripts, os quais fariam chamadas a vários scripts independent es, seria possivel a realizaçāo de tarefas mais complexas.

Desta forma, o projeto Discover seria como uma série de scripts independentes que poderiam ser compostos conforme as necessidades dos usuarios. Entretanto, surgiu a proposta de se criar um ambiente integrado, com uma interface grática bem definida. que auxilie, visualmente. a composição do processo de Extração de Conhecimento (Geromini 2000). Desta maneira, deverá scr construido, pelos alunos do próprio laboratório, um softuare através do qual o pesquisador possa "montar" o processo de Extração de Conhccimento através de componentes visuais e da configuração dos atributos dos mesmos. 
O ambiente Discover pode ser cntendido como um conjunto de métodos que são aplicados sobre os dados ou sobre o conhecimento extraido a partir desses dados. Dessa forma, é muito importante que tal ambiente ofereça um base sólida para manipular dados c conhecimento. Essa base é composta por sintaxes padrão para a representaça de dados $\epsilon^{2}$ conhecimento, e por componentes que ofercçam um conjunto de funcionalidades bâsicas de manipulação de dados c conhecimento.

Através de interfaces bem definidas entre os componentes, devem ser utilizados no Discover métodos desenvolvidos pelos pesquisadores de AM e DM do LABIC e pela comunidade cientílica. Assim, pela integraçào destes diversos trabalhos e reúso dos componentes produzidos, espera-se obter um ganho na produtividade desses pesquisadores através da redução da repetitividade $\mathrm{cm}$ seus trabalhos. além de uma maior facilidade para realizaçāo de experimentos.

\section{A. 1.2 OReúso no Discover}

Pode-se perccber entāo que a decisāo por implantar o reúso de componentes no processo de extração de conhecimento de bases de dados partiu de professores do LABIC que. em conjunto com seus orientandos. perceberam a necessidade de reduçào do re-trabalho até entào executado. A partir desta necessidade, o LABIC. mais espccificamente o ambiente Discover, foi selecionado como dominio de exccução do estudo de caso deste trabalho.

É válido ressaltar a importância desta necessidade ter sido reconhecida pelo maior nivel hieräquico do laboratório, seus prolessores. Tal fato garantiu o "apoio gerencial" aos trabalhos realizados. fator extremamente necessário para o sucesso dos mesmos. Além disso, tal fato também conferiu importància e credibilidade aos csforços para melhoria do proces so perante os desenvolvedores do laboratório. facilitando e melhorando sua receptividade por parte dos mesmos.

Participaram ativamente do estudo de caso três alunos do LABIC (dois mestrandos e um doutorando), assumindo o papel dos especialistas no dominio da organizaçāo, e uma aluna do $\mathrm{LABES}^{1}$ (mestranda autora deste trabalho), exercendo o papel de engenheira de software e mediadora das reuniōes. Valc ressaltar que todos os documentos gerados e mensagens trocadas por e-mail (método de comunicaçào oficial e formal) pelo grupo foram enviados com cópia para a orientadora da aluna e para uma das professoras do LABIC. relacionadas ao Discover que, por sua vez, era a orientadora dos outros três integrantes do grupo de trabalho.

\footnotetext{
'Laboratório de Engenharia de Sofluare do Instituto de Cièncias Matemáticas e de Computaçāo da USP/São
} Carlos. 


\section{A.2 As Reuniões}

Os trabalhos de definiçāo de requisitos para implantaçāo do reúso no LABIC ${ }^{2}$ foram agrupados por assunto e, posteriormente, reuniōes para tratar de cada um desles assuntos foram agendadas. A primcira reunião do estudo de caso abordou os temas quc seriam discutidos no decorrer dos trabalhos, além de um cronograma de reuniōes para tratar de cada um destes temas. As reuniōes seguintes abordaram questōes como gerenciamento de configuração e requisitos para documentação cxterna.

A seguir. cada uma das reuniões realizadas é descrita em mais detalhes. Vale ressaltar que as reuniōes do estudo de caso, apresentadas a seguir, foram precedidas por algumas outras reuniōes com o intuito de identificar o que o grupo desejava realmente implantar. O que se percebeu foi que o grupo desejava organizar os programas desenvolvidos de maneira a permitir quc outros pesquisadores pudessem reaproveitá-los. ou seja, pretendia-se praticar o reúso do código-fonte produzido. $\Lambda$ partir desta definiçāo, o estudo de caso foi planejado.

Como foi cilado na Seçāo 8.4. documentos de diretrizes, atas e resoluçōes foram criados. Neste capitulo, tais documentos serāo citados quando necessário. Porém, é importante ressaltar que as atas foram construidas para todas as reuniōes, independente de seu assunto ou resultado, e que cada um dos tópicos abordados deu origem a um único documento de diretrizes e de resoluçōes.

\section{A.2.1 Reunião l: Validação do Cronograma}

Esta rcuniāo foi agendada para o dia 17/05/2002 e abordou o Plano de Trabalho proposto pela aluna que, como já foi dito. exerceu o papel de engenheira de softuare nas reuniōes. Nela foram discutidas questōes como os assuntos a serem abordados durante os esforços para introdução do reúso, sua ordem de abordagem, as datas das reuniōes c a forma como clas seriam realizadas.

Foi sugerido pela aluna que as reuniōes seguissem o metodo FAST, proposto por Pressman (1997), incluindo esta primeira reuniāo. que permitiu que os alunos o conhecessem e: avaliassem. Assim, foi preparado um documento sobre o conteudo a ser tratado na reu nião e o mesmo foi enviado aos seus participantes junto dc uma breve explicação sobre a forma como a rcuniāo deveria acontecer. ou seja. o documento deveria ser lido previamente c somente discutido durante a reuniāo.

${ }^{2}$ Guando lor mencionado o LABIC, entendia-se pesquisas e pesquisadores do LABIC ligados ao Discover. 
A reunião transcorreu tranqüilamente c os tópicos sugeridos no documento de diretrizes foram accitos integråmente. Assim, a seqücncia de tópicos a serem abordados em reuniōes foi: documentação interna, documentaçäo externa, revisão tẹcnica formal c gerencianento de configuração. Nlém disso, algumas outras resoluçōes foram tomadas:

- O método de realização das reuniōes foi aprovado e elogiado, sendo ressaltado que os documentos construidos poderiam ser utilizados como documentação do processo de desenvolvimento do cstudo de caso:

- Assim que definidos os requisitos para cada um dos tópicos, os mesmos deveriam ser apresentadas a todo o grupo de trabalho do LABIC relacionado à extraçáo de conhecimento de bases de dados e efctivamente implantados;

- Após um determinado tempo de uso, a execuçăo destas atividades deveria ser checada a fim de que se levantasse c corrigisse os pontos problemáticos.

Nesta reuniāo também foram discutidas questōes como a viabilidade das atividades de controle de mudanças c revisão tćcnica formal. Estas atividades foram consideradas de difícil implantação pelos alunos do LABIC já que, provavelmente, náo existiria uma pessoa que pudessc assumir a responsabilidade de exccuta-las. Além disso. no caso da atividade de revisão técnica formal, foi levantada a questäo de quais itens poderiam ser avaliados. do scu grau de dificuldade e da importância cm realizá-la. Porém, como estes tópicos seriam tratados posteriormente. nada foi definido.

Uma outra questão abordada na reunião tratou da ferramenta a ser utilizada para o gerenciamento de configuraçāo. Foram apresentadas duas possibilidades: o uso da ferramenta WINCVS (Harper 2001) ou a construçào de uma ferramenta que englobasse nāo somente o armazcnamento e controle de versão dos componentes (realizado através do uso do CVS (Cederqvist. Grubbs, Brunskill, Dyer. Pingle, Peterson, Wallin, Koschuetzki, \& Brown 1992)\}. mas também funcionalidades referentes ao processo execução de revisōes e à busca de componentes. No entanlo, este assunto foi apenas discutido, sendo a opção por uma dessas possibilidades adaiada para as próximas reuniōes.

Scguindo o calendário entào estabclccido, a próxima reuniāo abordou o tema "Definiçào dos Requisitos para o Código-fonte".

\section{A.2.2 Reunião Il: Definiçâo dos Requisitos para o Código Fonte}

Esta reuniāo foi rcalizada no dia 24/05/2002 e teve como objetivo a padronizaçāo do código-fonte desenvolvido $\mathrm{cm}$ projetos relacionados ao Discover. Esta atividade foi impor- 
tante, pois com cla procurou-se organizar c padronizar o código desenvolvido de maneira a facilitar a sua leitura c compreensão por outros pesquisadores conhecedores do padrão.

Para o desenvolvimento do documento de diretrizes, foram pesquisados diversos documentos de padrōes para diferentes linguagens, como JAVA e C. Estes padrōes foram analisados e confrontados com as necessidades de um código com o objetivo de ser reutilizado, dando origem às diretrizes aprescntadas na reunião. Vale ressaltar que, no documento produzido. ou seja, nas diretrizes apresentadas, não se fez menção a nenhum tipo de linguagem especificamente.

A maioria dos tópicos sugeridos foram accitos. porém ficou definido que eles seriam classificados em itens obrigatórios $\mathrm{c}$ itens fortemente recomendados. $\Lambda$ justificativa para esta classificaçāo reside no fato de os alunos considerarem que a padronizaçāo de alguns itens não è tão importante e que o cxcesso de regras poderia limitar por demais a maneira de trabalho dos pesquisadores e trazer descontentamento aos mesmos. Alćm disso. alguns itens foram inseridos ou desconsiderados por fazerem ou nāo, respectivamente, sentido no contexto da linguagem Perl, utilizada pelo grupo no desenvolvimento de programas para o Discover.

As resoluçōes finais do LABIC para este tópico incluem. em comparaçāo com as diretrizes apresentadas na Seçāo 8.5.1 para a documentação interna:

- Todos os itens apresentados para a identificaçāo de código. exceto o dominio da revisão do componente:

- Os requisitos para identaçāo:

- Os requisitos para comentários, exceto informaçōes referentes ao tipo dos parâmetros (entrada ou saida) e ao valor de retorno dos metodos:

- O padrão sugerido para nomenclatura, acrescido de regras para identificadores de arquivos. variáveis globais dentro da classe e dentro dos métodos (necessárias para a implementação de classes em Perl);

- Os requisitos para classes, métodos e sub-classes, acrescidos da necessidade da existência obrigatória de um atributo (na classc) de nome class_version. cujo conteúdo seria a versão da classe ou sub-classe. Foram eliminados os requisitos referentes à informação de que as variáveis devem ser declaradas no inicio do método/classe e à exigência da nāo existência de variáveis globais: 
- Os requisitos para tamanho c quebra de linhas:

- Os requisitos para uso linhas c espacos em branco:

- Todos os itens apresentados para declaraçōes. exceto a recomendação para rcalizar apcnas una declaraçāo por linha. Foi acrescido ainda a necessidade se utilizar o comando use strict que obriga. além de outras coisas. a declaraçāo de todas as valiáveis na linguagem $\mathrm{rerl}$;

- Todos os requisitos para comandos de inicio/fim de bloco e para comandos sim ples/compostos, exceto pelo fato de terem seu uso apenas fortemente recomendado;

- Para o tratamento de erros foi definido que deve-se. obrigatoriamente. seguir. quan do possivel, as exceçôes padrão a serem definidas pelo grupo. Quando isto nào for possivel, o contexto de exccuçāo da exceçāo deve ser muito bem documentado;

- Os requisitos para utilização de parènteses, exceto pelo fato de terem seu uso apcnas fortemente recomendado:

- Foi selecionado o uso obrigatório do Inglés como idioma olicial:

- A hierarquia dos componentes deveria ser definida pclo grupo e todo componente deveria scr classificado em um dos niveis da mesma. Caso isso não fosse possivel, o desenvolvedor deveria entrar em contato com o responsável pela divisão hierárquica, o qual teria autoridade para resolver a questāo;

- As diretrizes especificas para o desenvolvimento de código oricntado a objetos foi baslante modificada devido as particularidades da linguagem Perl. Entre as diretrizes sclecionadas (mantidas ou inseridas) estāo: nāo utilizar hcrança múltipla, separar os métodos redefinidos nas sub-classes, documentar quando um mëtodo deve ser redefinido, manter as classes. sub-classes c métodos pequenos (com menos de 25 métodos. 10 novos métodos e 30 linhas, respectivamente). manter o número de paràmetros baixo (menos de 5), declarar em comentário se um método é constant, considerar e utilizar os atributos da classe como se fossem private e nảo utilizar suitch nos tipos de objetos.

Ficou dccidido também que os alunos do LABIC participantes da reuniāo seriam responsáveis pela construçāo de: um documento contendo requisitos de código especificos para a 
linguagem Perl, um exemplo dos requisitos definidos nesta reuniāo (programa cm Perl, seguindo todos os requisitos definidos) e um documento contendo as regras para tratamento de erros. incluindo as excecôes padrão a serem utilizadas pelos desenvolvedores.

A reunião seguinte abordou a definição de requisitos para a construçāo da documenta ção extcrna dos programas.

\section{A.2.3 Reuniāo III: Definição de Regras para Documentação de Externa}

Esta rcunião foi realizada no dia 07/06/2002 e teve como objetivo a padronizaçāo do conteúdo e da formatação da documentação externa dos componentes. facilitando assim a sua leitura e comprcensāo por outros pesquisadores conhecedores do padrāo.

Para o desenvolvimento do documento de diretrizes, foram pesquisados diversos docu. mentos que apresentassem sugestões para a construção de uma documentação de utilidade efetiva. Analisando estes documentos e confrontando-os com a realidade de pequenos grupos de desenvolvimento, nos quais, na maioria das vezes, a documentação ć vista apenas como "perda de tempo". procurou-se identificar itens importantes para a construção de uma documentação que suprisse as necessidades do reúso. Desta análise, surgiram as diretrizes aprescntadas na reuniāo.

Logo no início dos trabalhos de pesquisa para esta reuniāo surgiu uma dúvida que. percebcu-sc entāo. deveria ter surgido e sido esclarccida na reunião anterior: O que seria um componente? Una classe, um metodo, um script? Optou-se entāo pela aprescntaçāo, no documento de diretrizes, de informaçōes consideradas importantes independente de o que seria considerado um componente no Discover. Esta discussão deveria scr apresentada ao grupo de trabalho durante a reunião c os cspecialistas no dominio seriam os responsáveis por tal decisāo.

É importante citar que, inicialmente, o objetivo desta reuniāo cra somente padronizar o conteúdo da documentaçāo extcrna. A idéia de padronizar também a formataçāo desla documentaçāo. ou seja, a forma como as informações cstariam nela dispostas, surgitu durante a construçāo do documento de diretrizes. Foi entāo considerada a possibilidade de desenvolvimento de um template, ou seja, um documento padrão no qual as informacōes seriam previamente distribuidas e os desenvolvedores deveriam apenas preencher os campos requisitados. Desta maneira, por diminuir o trabalho dos desenvolvedores na confecçào da documentaçāo, esperava-se diminuir tambèm sua rejeiça à mesma. No estudo de caso. foram propostas duas opcões de template: um formuläio em um documento $M i^{-}$ crosoft Word, cuja utilização é bastante conhecida pela maioria dos desenvolvedorcs, ou 
a construção de uma aplicacão disponibilizada em rede para preenchimento do formulário. com suas informaçōes salvas em una base de dados. Nlgumas das vantagens desta segunda opçào, apresentada como recomendada, sāo:

- $\Lambda$ independência da localização e a nāo necessidade de se ter o formulário em um determinado computador. No caso da aplicaçào $\mathrm{cm}$ rede. o formulário poderia ser acessado por qualquer computador e usuário com acesso ao mesmo;

- $A$ independencia da tecnologia Microsoft

- A construção automática da documentação externa (cujo formato sugerido foi o PDF) através do $\mathrm{BT}_{\mathrm{E}} \mathrm{X}$.

A primeira questào discutida na reuniāo foi o que seria considerado um componente, isto porque esta informação traria impactos na definição dos requisitos para a documentação externa. Foram analisadas consideracōes como o tipo de estrutura que o grupo costumava desenvolver. as possibilidades da linguagen que o mesmo utilizava, o que seria reutilizado. a unicidade da funcionalidade do componente (como recomendado por Karlsson (1995)), a estrutura dos componentes que já estavam prontos e sua accitação no repositório. Por consenso, foi definido que todos os componentes do repositório seriam classes. Os programas quc já estivessem prontos e năo fossem classes seriam transformados por seus autores. Esta decisāo resultou na necessidade de se alterar os requisitos definidos para o codigo-fonte. Por isso, foi criado o documento de resoluçōes cujo objetivo é documentai alteraçōes nos requisitos inicialmente definidos, sem, com isso, precisar alterar as alas de reunião. Por motivo de padronização dos trabalhos, optou-se por criar, para cada um dos tcmas analisados, o documento de diretrizes e o documcnto de resoluçōes. $\Lambda$ ata deveria ser criada para cada uma das reuniōes.

Como já se previa. foi levantada na reuniāo a preocupaçāo do grupo em nāo sobrecar regar os desenvolvedores na construção da documentaçāo, o que poderia desestimulá-los. Com base nesta preocupaçāo. o grupo optou pela segunda opção de template, ou seja, pela construção de um aplicativo disponivel em rede para a documentação dos componentes. Desta mancira, as informacōes desta documentaçāo seriam mantidas em uma base de dados e utilizadas posteriormente para outras atividades, como busca, por exemplo. Deveria ser disponibilizada tambèm a funcionalidade de geraçāo de documentos, no formato $\|_{\mathrm{E}} \mathrm{X}$. contendo as informações dos componentes. 
Foi levantado também o problema da dificuldade existente para se reunir tudo o que já havia sido programado c a necessidade das orientadoras destes membros participarem do incentivo, e se necessário, da cobrança da execução deste tipo de atividade.

$\Lambda$ s resoluçôes finais do LABIC para este tópico incluem, em comparaçāo com as diretrizes apresentadas para a documentaçào externa na Secão 8.5.1:

- Os mesmos itens referentes à documentação da classe como um todo (incluindo a cardinalidade), exceto a cardinalidade da informaço de classificação hierárquica (1 .. N no caso do LABIC). a informação de domínio para a revisão (inexistente no caso do LABIC) e a informação de arquivo da classe no CVS (inexistente na proposta apresentada na Seção 8.5.1);

- Os mesmos itens referentes à documentaçāo dos métodos, exceto a informação reférente aos arquivos dos documentos anexos no CVS (inexistentes na proposta da secäo 8.5.1), c a informação do valor de retorno do método (inexistente no caso do LABIC);

- Os mesmos itens da documentaçāo a serem utilizados na busca de componentes.

As duas reuniōes seguintes abordaram o tema Revisão fécnica Formal è serào apresentadas na próxima seção.

\section{A.2.4 Reuniões IV e V: Definição do Processo de Execução de Revisões Técnicas Formais}

Este assunto foi abordado em duas reuniōes. Na primeira delas deveria ser definida a forma de execução das revisões e na segunda um ou mais componentes deveriam ser submetidos ao processo definido a fim de avaliar sua adequabilidade e. se necessário. modificá-lo.

A primeira reuniào ocorreu no dia 24/06/2002. A construçāo do documento de diretrizes para esta reuniảo teve como base os livros de Berlack (1992). Pressman (1994), Pressman (1997) e da Rocha. Maldonado, \& Weber (2001). o artigo de Ambriola, Bendix, \& Ciancarini (1990) e a dissertação de Pacheco (1997). E importante ressaltar que, com o decorrer dos trabalhos. a neutralidade das diretrizes, a sua independencia do estudo de caso foi comprometida, pois as mesmas precisavam tomar como base as decisōes tomadas cm reuniōes anteriores, decisōes estas particulares an LABIC.

O documento de diretrizes iniciou-se com uma breve discussão geral sobre revisão técni. ca formal, apresentando seu conceito, objetivos, vantagens e desvantagens. A apresentaçăo 
de tal discussão foi julgada necessária em razão de a maioria dos participantes da reuniāo não serem da área de Engenharia de Software e, possivelmente, não conhecerem o assunto. Seu objetivo toi nivelar basicamente o conhecimento dos participantes das reuniōes neste assunto. Posteriormente, foi apresentado um processo de execucão de revisóes bastante semelhante ao apresentado na Seção 8.5.2, incluindo aprovação, aprovação provisoria t reprovação de componentes, alem dos requisitos para a aprovação provisória e definitiva dos mesmos.

Esta reunião, como já se imaginava, gerou bastante polêmica entre o grupo, visto quo abordava um lópico cuja aceilaçāo nāo scria muito fácil cm virtude dos recursos necessários e da "burocracia" gerada. Diversos problemas foram discutidos na reuniāo, sendo o principal deles a probabilidade da inexistencia dos recursos humanos necessários para a exccucão das revisões. Porém, como a disponibilizaçāo de recursos estava fora do escopo de responsabilidades dos participantes da reunião. o grupo optou por adiar a mesma ate que se resolvesse a questão com um professor.

Uma outra questão abordada na reunião foi a necessidade de se apresentar ao restante dos alunos relacionados ao Discover as regras para documentaçào externa c, principal mente, para codificação dos componentes. Porém. a questāo foi apenas discutida e nada foj definido.

A segunda reunião sobre revisão técnica formal foi realizada no dia 04/07/2002. No periodo entre a primeira e a segunda reuniāo, os alunos do LABIC participantes da reuniāo entraram em contato com uma das professoras responsaveis pelo Discover para decidir sobre a realização ou nāo das revisôes, c, caso se optasse por realizá-las, como isto seria feito. Como a segunda reuniāo foi apenas uma extensão da primeira, não foi apresentado nenhum documento de diretrizes.

Com base no histórico de discussōes sobre o assunto em reuniōes anteriores, esperavase que o grupo optasse por nāo implantar as revisōes, que, ao que parecia, cra considerado pelos alunos do $\mathrm{A} A \mathrm{BIC}$ um trabalho muito oneroso e até certo ponto "desnecessário" ao grupo, o qual, por sua ve\%, deveria "confiar" no trabalho de seus desenvolvedores, como mencionado pelos próprios alunos. Porém. nāo foi esta a opcão da professora. Segundo o que foi apresentado pelos alunos, a professora optou pela implantação de uma revisāo simplificada - a verificação, visto que năo seria mesmo possivel ter alunos integralmente disponiveis para a execuçāo de revisoes, embora esta disponibilidade não fosse imprescindivel. Além disso, os alunos que ficariam entāo responsàveis por realizá-las nāo poderiam ser sobrecarregados por esta atividade. pois scu foco principal deveria ser em seus projetos. 
O processo de revisão foi entāo simplificado, passando a ser uma verificação realizada através de revisōes e abordando somente questōes muito importantes para manter um minimo de coerēncia cntre a documentaçāo externa e o código. informaçōes importantes para a busca dos componentes e informaçōes essenciais para identificação do código. As principais caracteristicas do processo adotado são a restricão do resultado da revisão pará componentes aprovados e reprovados, e a seleção de algumas características com as quais os componentes já poderiam ser aprovados. É importante ressaltar que, da maneira como foi definida a revisāo, determinados itens dos padrôes estabelecidos para documentação, embora obrigatórios, somcnte scrāo realmente respeitados se houver colaboração dos desenvolvedores dos componentes, visto que tais itens nāo são vistoriados, exigidos na revisāo.

Como mencionado no inicio desta seção, pretendia-se realizar uma revisảo piloto, a fim de testar a viabilidade do processo definido. Porém, como a execução deste teste atrasaria o cronograma e nāo era extremamente necessária, o grupo optou por não rcalizá-la.

A questāo da passagem dos requisitos definidos aos desenvolvedores foi novamente abordada nesta rcuniāo. A preocupação residia no fato de estes desenvolvedores passarem a construir programas seguindo o padrão o mais rápido possivel, a fim de que não tivessen que modificá-los posteriormente, tarefá esta onerosa, desagradável e passivel de introdução de erros no código. Foi decidido que seria construido c disponibilizado na rede um süte contendo as resoluçōes e um componente exemplo que seguisse os padrōes estabelecidos. Além disso, o documento de requisitos refercntes à linguagem Perl também deveria ser disponibilizado neste site. Posteriormente, deveria ser ministrada uma palestra a fim de apresentar os novos padröes aos desenvolvedores, ilustrando-os c solucionando duvidas caso surgissem.

$\Lambda$ próxima reuniāo abordou o tema gerenciamento de configuraçāo de softuare.

\section{A.2.5 Reunião VI: Definição do Plano de Gerenciamento de Configuração}

No cronograma proposto, este assunto foi separado em cinco reuniōes cujos assuntos seriam: definição do processo de controle de mudanças, definiçào do processo de controle de versòes, definição do processo de controle de acesso, definiçāo do processo de notificação de mudanças e definição do processo de manutenção de histórico. Esta divisão foi definida porque, inicialmente, acreditava-se que principalmente as duas primeiras reuniões desta seqüència seriam muito polêmicas e extensas. No entanto. ao preparar o documento de diretrizes, percebeu-se que seria uma melhor opçào construir este documento abordan- 
do todas estas questōes. Na reunião. realizada no dia 14/08/2002, os assuntos seriam tratados individualmente, conforme apareccssem no documcnlo. Caso esta reuniāo se estendesse por muito tempo, cla deveria ser suspensa ao final de um determinado tópico e retomada posteriormente. Porém, tal interrupçāo não foi necessária c todos os tópicos foram abordados por completo em uma ünica reunião.

Para confecçào do Plano de Gerenciamento de Configuraçāo proposto, tomou-sc como base o trabalho descnvolvido por l'acheco (1997). Neste trabalho. o autor abordou a im plantação do gerenciamento de configuraçāo cm organizaçôes de pequeno porte, cujo ambiente é semelhante ao encontrado em um laboratorio de pesquisa. Sendo assim, foram feitas algumas adaptaçôes no plano proposto por Pacheco (1997), a fim de satisfazer às particularidades do IABIC, como, por cxemplo, a inexistencia de uma estrutura hierárquica do tipo diretor-gerente-equipe de desenvolvimento.

A parte mais importante do plano é a que define a forma como as tarefas do gerenciamento de configuração serão execuladas. No item que trata da seleção dos itens da configuração, o grupo de trabalho definiu que fariam parte da configuraçāo os arquivos de código-fonte dos componentes e todos os arquivos referentes à sua documentação externa. No itcm que trata das linhas de referencia. foram definidos alguns momentos nos quais. se os desenvolvedores relacionados ao Discover não tiverem disponibilizados determinados produtos (os componentes que estão em descnvolvimento c os componentes que estão prontos), uma mensagem deveria ser enviada do pesquisador e ao seu orientador avisando que o prazo para entrada das informaçōes terminou e ele ainda não a fez. No item que aborda a identificaçāo dos itens da configuraçāo, a nomenclatura definida inicialmente foi mantida c acrescida de regra para contemplar a nomenclatura dos arquivos. No item que aborda a organizaçāo do repositório, foi decidido que o mesmo deve ser dividido em diversos módulos, representando a classificaçào hierárquica dos componentes e, em última instáncia, os próprios componentes. No item que trata do corıtrole da configuraçāo, foi definido que alteraçōes nos componentes somente poderiam ser realizadas mediante solicitação c aprovação formal das mesmas. No item que aborda o relato da situação da configuração, ficou decidido que serão definidos pelo IABIC os relatórios julgados nccessários (e as informações que nele estarão contidas) e a quem os mesmo serão disponibilizados. Os itens que tratam da auditoria da configuraçāo. do controle de interface e do controle de sub-contratados e fornecedores não serāo implantados, ao menos inicialmente. por motivos diversos. Foi definido tambem um roteiro para implanlação do gerenciamento de configuração e de todos os outros processos e padrões definidos nas reuniōes no 
dia a dia dos desenvolvedores do LABIC. Foram estabelecidas as necessidades de recursos humanos, equipamentos e sofitware necessários, e o processo de manutençāo do plano do gerenciamento de configuração.

Foi definido também que as tarefas tanto do gerenciamento de configuração como das revisōes possiveis de sercm automatizadas serāo implementadas na ferramenta proposta para padronizar a organização da documentaçāo externa (citada no final da Seção A.2.3).

Foi solicitada nesta rcuniāo, a inclusāo na ferramenta de documentacão de uma funcionalidade referente a divulgacão de problemas (bugs) nos componentes. Foi definido que seria disponibilizada uma área para apresentação dos bugs contendo as seguintes informações: descrição do problema ou bug, versão do componente na qual o problema foi encontrado, data da descoberta do problema. autor da descoberta, correção do proble ma, autor da correçāo, data da correção e versão do componente na qual o problema foi corrigido.

Esta ferramenta teve sua construção inicialmente atribuida a um dos participantes da reunião (pertencente ao LABIC). Posteriormente, em função das novas funcionalidades a ela atribuidas, decidiu-se que a engenheira de software do grupo de trabalho faria a modelagem da ferramenta e a implementação da mesma deveria ser discutida pelos alunos do grupo do LABIC com as professoras relacionadas ao Discover. Depois de disculida a questão da implementaçāo, o aluno anteriormente selecionado para fazêt-la teve sua alocação para tal tarefa confirmada.

Logo após esta ŭltima rcuniāo, cm conversas informais com integrantes do LABIC relacionados ao Discover, estes perguntaram quando os padrões definidos serian a eles apresentados. Sua preocupação residia na necessidade de terem que alterar, e conscqücntementc re testár, uma grande quantidade de código-fonte. Nesse momento, percebeu-se que já háavia uma certa aceitaçâo (e até mesmo interesse), por parte dos desenvolvedores, ao menos da ideia de que teriam seus códigos submetidos a padrōes de construçào, o que poderia facilitar bastante a atividade de implantaçāo dos requisitos e atividades definidos. 